Flávia Hellmeister Clito Fornaciari

\title{
REPRESENTATIVIDADE ADEQUADA NOS PROCESSOS COLETIVOS
}

Tese de Doutorado

Professora Orientadora Ada Pellegrini Grinover

Faculdade de Direito da Universidade de São Paulo São Paulo

2010 
A minha mãe, Maria Teresa, por ter-me ensinado a importância das palavras 


\section{AGRADECIMENTOS}

Agradeço à Professora Ada Pellegrini Grinover, pela constante e preocupada orientação, que me ajudou a delimitar o tema, a desenvolvê-lo e a recolocar o trabalho em seu prumo sempre que seus objetivos eram desviados.

Agradeço aos Professores Kazuo Watanabe e Rodolfo de Camargo Mancuso, pelas valiosas orientações na banca de qualificação, que foram imprescindíveis para que o trabalho fosse concluído.

Agradeço também aos Professores Cândido Rangel Dinamarco, José Roberto dos Santos Bedaque, Carlos Alberto Carmona, Carlos Alberto de Salles e Susana Henrique da Costa, pelas aulas proferidas no curso de pós-graduação e pelo auxílio na discussão de ideias.

Agradeço a meus colegas de pós-graduação, especialmente Ricardo de Carvalho Aprigliano, Bruno Silveira de Oliveira e Marcelo Pacheco Machado, pela amizade, pelas diversas ideias debatidas e pelos momentos de descontração, essenciais para que aqui se chegasse.

Agradeço, por fim, a meu pai, Clito, pelo constante apoio e orientação, a minha mãe, Maria Teresa, pelo apoio e auxílio na revisão do trabalho, a meu irmão, Fernando, pelo companherismo, e ao Rodrigo, pelo eterno incentivo e pela compreensão da exiguidade do meu tempo. 


\section{SUMÁRIO}

1. Introdução 05

2. Direitos Coletivos e Processos Coletivos ....................................................................... 10

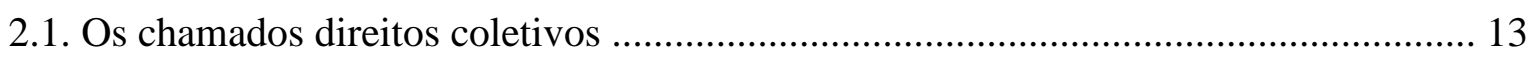

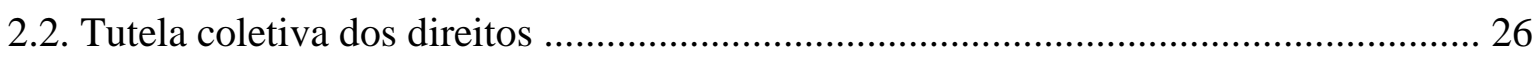

2.3. Nascimento e desenvolvimento das class actions no sistema de common law ........... 33

2.3.1. Os requisitos e as hipóteses de cabimento das class actions norte-americanas ....... 37

2.4. Evolução da proteção aos direitos coletivos no Brasil ................................................ 44

3. Representatividade Adequada .......................................................................... 47

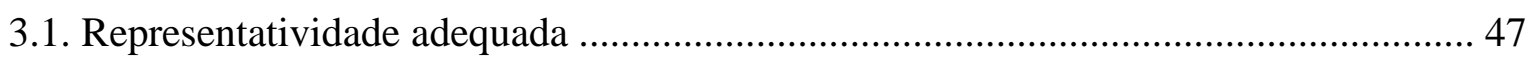

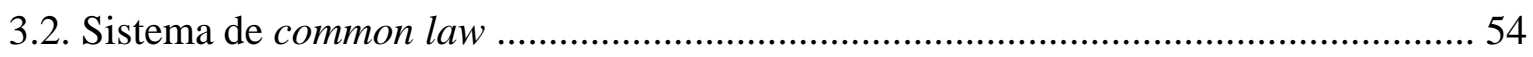

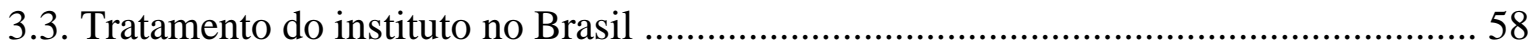

4. Representatividade Adequada, Legitimidade e Interesse de agir .............................. 65

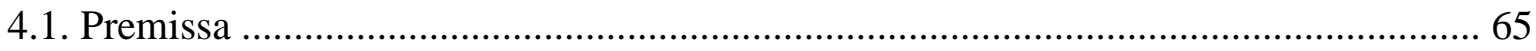

4.2. Legitimidade e interesse no processo civil clássico ................................................... 66

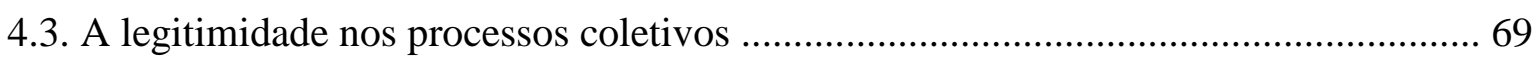

4.3.1. O Ministério Público como legitimado .................................................................. 74

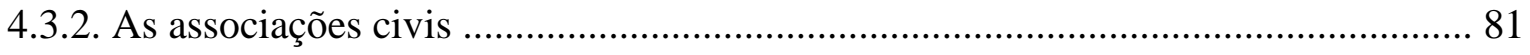

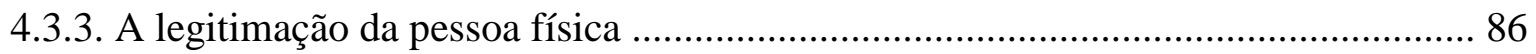

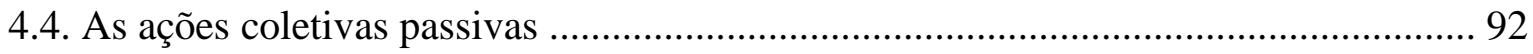

4.4.1. As defendant class actions no direito norte-americano ......................................... 93

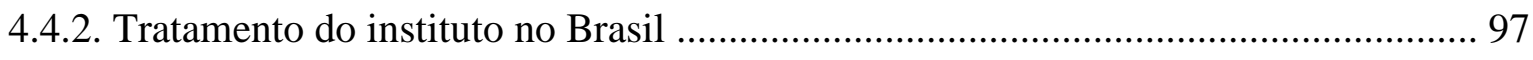

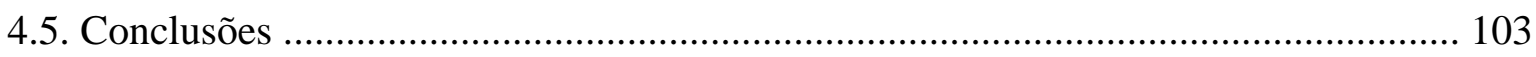

5. Representatividade Adequada e Coisa Julgada ............................................................... 106

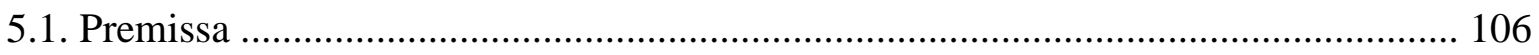

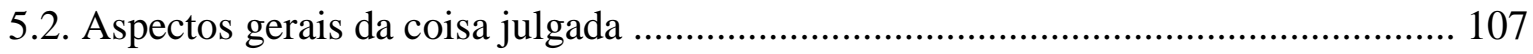

5.3. O regime da coisa julgada no sistema processual brasileiro clássico - limites subjetivos 


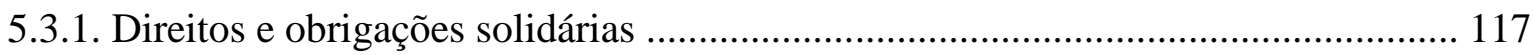

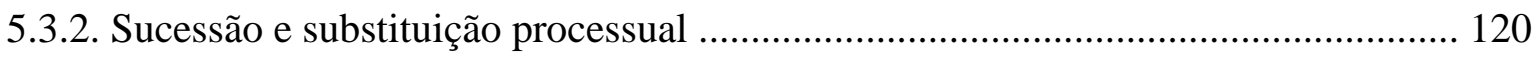

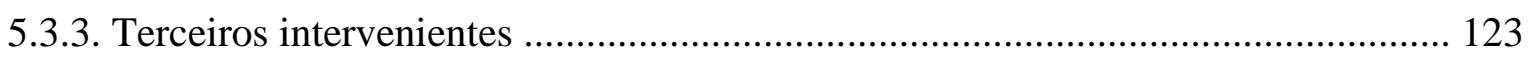

5.4. O regime da coisa julgada no sistema de common law ......................................... 128

5.5. Espécie de coisa julgada no processo coletivo brasileiro ....................................... 133

5.5.1. Coisa julgada em processos relativos a direitos difusos e coletivos ...................... 137

5.5.1.1. Inconstitucionalidade da limitação da coisa julgada ao território ........................ 137

5.5.1.2. Improcedência por falta de provas e coisa julgada secundum eventum probationis

5.5.2. Coisa julgada nos processos relativos a direitos individuais homogêneos ............ 144

5.5.3. Coisa julgada na ação coletiva passiva ............................................................. 150

5.6. Análise da formação da coisa julgada em face do instituto da coisa julgada clássica, da representatividade adequada e dos objetivos do processo coletivo 153

6. Considerações finais 163

Bibliografia 172

Resumo 186

Abstract 187

Riassunto 188 


\section{INTRODUÇÃO}

O objetivo central do presente estudo é a análise do instituto da representatividade adequada nos processos coletivos, tentando-se não apenas delimitar seu conceito, mas também anotar os meios de sua aplicação e as consequências que podem advir de sua efetiva observância pelo Judiciário, além de buscar modos pelos quais a utilização do instituto possa contribuir para uma maior efetividade na defesa desses direitos.

O tema se justifica, em primeiro lugar, por sua dimensão geral, a dos processos coletivos, faceta de certo modo nova no ordenamento brasileiro, visto seu estudo ter aqui se iniciado com mais rigor há pouco mais de três décadas. Até então, os direitos coletivos, espécie de direitos protegidos por meio dos processos coletivos, eram muito pouco analisados, tinham pífia legislação voltada à sua defesa e eram minimamente trazidos à apreciação pelo Judiciário, de forma que não eram quase defendidos.

Atualmente, não podem existir dúvidas de que os processos coletivos podem ser instrumentos muito importantes para a pacificação dos conflitos de maneira generalizada, garantindo, ao mesmo tempo, o acesso à justiça, mas sem atolar a máquina judiciária, porque proporcionam a solução molecular de uma série de controvérsias, que poderiam ser submetidas ao Judiciário de forma individual e fragmentada. Ressalta-se, inclusive, um importante aspecto, que deve sempre ser buscado para poder afirmar-se sua eficiência, que é a redução da litigiosidade futura, o que qualquer ordenamento jurídico almeja.

No entanto, o estudo dessa sorte de direitos revelou-se necessário, por força das transformações da sociedade e do próprio Estado, visto que os sujeitos de direito deixaram de ser considerados indivíduos isolados e passaram a ser vistos como cidadãos, integrantes de grupos, atuantes na sociedade. Com isso, as relações sociais ampliaram-se e impuseram que se aumentasse o espectro do que até então se considerava um direito, a fim de que nesse conceito fossem inseridos os interesses coletivos dos indivíduos que vivem em sociedade. E, por conta disso, atentando para as modificações sociais, fez-se necessária a criação de dispositivos legais aptos a defenderem essa nova sorte de direitos. 
Nos ordenamentos de common law, a proteção dos denominados direitos coletivos ocorre há período substancialmente mais longo, havendo já nas origens do ordenamento inglês previsões nesse sentido. No entanto, a partir dos séculos XVIII e XIX, a defesa desses direitos tornou-se mais evidente, especialmente após a independência dos Estados Unidos da América, que passaram a desenvolver o instituto com maior preocupação e propriedade. Assim, naquele país, a tutela coletiva dos direitos já é tradicional, tendo o Brasil e inúmeros outros países de civil law se inspirado na experiência daquele ordenamento para criação de suas legislações, observando-se, é claro, as peculiaridades de cada qual.

A própria Constituição Federal Brasileira trouxe dispositivos bastante importantes para que se permitisse a aceitação pelo ordenamento da possibilidade de proteção desses direitos, elencando, já o rol de garantias de seu artigo $5^{\circ}$, os direitos e deveres não só individuais, mas também aqueles coletivos. Além das garantias constitucionais, a Lei da Ação Civil Pública (Lei n. 7.347/85) e o Código de Defesa do Consumidor (Lei n. 8.078/90) são as disposições legais mais importantes que regem, de maneira conjunta, os processos coletivos brasileiros.

Todavia, os dispositivos legais que tratam das ações coletivas atualmente em vigor são fracionados e não apresentam, nem em sua parte material nem naquela processual, elementos básicos unificadores da disciplina dos processos coletivos. Em vista disso, os estudiosos do tema buscam a unificação deles, visando à criação de um Código Brasileiro de Processos Coletivos, para, com isso, propiciar uma maior efetividade na aplicação da lei e na defesa dessa sorte de direitos. Houve a elaboração de dois Anteprojetos sobre o tema, um decorrente de estudos da Universidade de São Paulo (que, neste trabalho, é o Anteprojeto sob análise quando assim referido) e outro da Universidade Estadual do Rio de Janeiro. No entanto, o Ministério da Justiça terminou por enviar, no início de 2009, um outro projeto ao Congresso Nacional (Projeto de Lei n. 5.139/09), sendo esse um momento importante para a discussão do que atualmente existe, do que, por meio dele, se pretende modificar e do que nele deixou de constar.

No que toca ainda ao Brasil, é interessante noticiar a existência de um Código Modelo de Processos Coletivos para Ibero-América, aprovado nas XIX Jornadas 
Iberoamericanas de Derecho Procesal, realizadas em Caracas, na Venezuela, em 2004. O Código Modelo, de acordo com sua exposição de motivos, inspirou-se no que já havia nas comunidades ibero-americanas, tentando homogeneizar as disposições, mas também criar "um sistema original, adequado à realidade existente nos diversos países iberoamericanos".

Diante da importância do tema em si e do momento de criação e modificação legislativa, merecem aprofundado estudo os direitos coletivos e o processo coletivo como um todo, justamente para que se tenha um incremento de sua aplicação no Brasil, uma vez que ela ainda é bem inferior ao que poderia ser, pois muitos dos aplicadores do Direito, com pensamento restrito no individualismo de civil law, ainda não absorveram o instituto.

Assim, buscar-se-á, neste estudo, não só analisar a questão à luz da lei posta, mas também em face do que dispõe o projeto de lei que trata do tema e o Código Modelo para Ibero-América; além disso, a intenção é também fazer anotações e sugestões críticas de lege ferenda, sempre com o objetivo de se desenvolver o instituto, o que é especialmente relevante, haja vista que o processo coletivo pode ser considerado o futuro da judicialização dos conflitos.

Dentre as inúmeras facetas e peculiaridades do processo coletivo, um de seus institutos mais importantes é a representatividade adequada dos indivíduos diretamente envolvidos na controvérsia. Isso porque esse tipo de ação é representativa, pois, via de regra, os interessados não são os autores da ação coletiva, mas, sim, o autor é um terceiro que os representa e deve fazê-lo de maneira adequada, a fim de garantir-lhes a correta defesa de seus direitos.

Nos Estados Unidos, existe uma elevada preocupação com a representação adequada pois, no ordenamento americano, não há um rol de pessoas legitimadas para a propositura da ação, como ocorre na grande maioria dos países de ordenamento romano-germânico, a exemplo do Brasil. A regra que estabelece as condições e requisitos da ação coletiva naquele país apenas determina que o representante seja membro da classe, cabendo ao juiz verificar se ele é idôneo, sério e capaz para reclamar, judicialmente, pelos interesses da classe, ou seja, se é um representante adequado. 
No Brasil, os legitimados para a propositura da ação coletiva estão especificados na lei, decorrendo a legitimação, pois, ope legis. Desse modo, não existe, a princípio, a necessidade estabelecida pela lei de o juiz verificar a adequação do representante que traz a controvérsia a juízo, sendo, pois, pouco aplicável, ao menos expressamente, o instituto no Brasil. No entanto, a pretensão desse trabalho é demonstrar que, mesmo com base na lei posta, há permissão ao magistrado para que ele faça essa verificação em relação ao legitimado ativo ou passivo, o que será de análise especial neste estudo, ao lado das proposições legislativas referentes ao tema e de invocações de lege ferenda que possam mostrar-se úteis ao seu desenvolvimento.

Ademais, a par da influência do instituto para a legitimação, vislumbrase que ele pode interferir em outras questões inerentes ao processo coletivo, podendo produzir efeitos, por exemplo, relativamente à disciplina da coisa julgada, que é distinta daquela aplicável aos processos comuns. Assim, buscar-se-á, neste trabalho, desenvolver as consequências, em geral, que a observância da representatividade adequada, que deve ser trazida como princípio do direito processual coletivo, pode gerar para a situação concreta posta sob a análise do Judiciário. Com isso, de lege ferenda, procura-se fazer com que o processo coletivo não seja apenas um caminho para que se tenha a devida observância desses direitos, mas que seja um elemento central voltado à defesa dos direitos coletivos e à solução das controvérsias que versem sobre eles.

Para o desenvolvimento desses propósitos, este trabalho foi dividido em quatro partes. Na primeira, de cunho geral, buscou-se fazer uma breve análise dos direitos coletivos, enfatizando-se seu nascimento, a distinção entre suas diversas espécies, amplamente consideradas, e os objetivos da tutela coletiva. Após, realizou-se um breve histórico do nascimento e desenvolvimento dos processos coletivos nos ordenamentos de common law e no Brasil, apontando-se a legislação que trata da matéria e de suas evoluções.

Dedicou-se uma segunda parte à definição e ao estudo de seu objeto central, a representatividade adequada, ressaltando-se sua disciplina no ordenamento brasileiro e naqueles de common law. Buscou-se, nesse momento, trazer o instituto de forma pura, desatrelado do processo, porque ele se liga, primeiramente, à relação de direito 
material e, somente num segundo momento, ao processo, etapa que foi posteriormente abordada. Até esse ponto, o trabalho teve pretensões apenas gerais e expositivas, como meio de se definirem questões e institutos que terão importância para o estudo crítico que se fez nas duas últimas partes.

Assim, nos dois últimos capítulos, buscou-se analisar as consequências da aplicação do instituto da representatividade adequada, fazendo-o, para tanto, primeiramente, em relação à legitimação ativa e passiva para a ação coletiva, objeto tradicionalmente ligado ao tema. O enfoque dado à análise é tanto de lege lata, por meio do apontamento de situações em que já se verifica a presença ou a possibilidade de presença do instituto, no que se inclui a atuação do Ministério Público e das associações e as ações coletivas passivas, como de lege ferenda, de modo a se contribuir para o seu desenvolvimento.

Por fim, a última parte dedica-se ao estudo crítico da extensão subjetiva da coisa julgada nos processos coletivos, no que se refere à possibilidade de influência pela representatividade adequada, o que se fez também não só em relação à lei posta. Esse cotejamento partiu não só da análise dos institutos já inseridos no ordenamento pátrio em que se vislumbra essa extensão, mas também da possibilidade de transposição de normas alienígenas para o sistema brasileiro. A análise de lege ferenda permitiu ainda que se verificassem meios pelos quais a exigência da observância do instituto da representatividade adequada pode trazer benefícios para uma maior efetividade na defesa dos direitos coletivos, sem prejudicarem-se os interesses de terceiros. 


\section{DIREITOS COLETIVOS E PROCESSOS COLETIVOS}

O Direito nasceu em sociedade com enfoque eminentemente individual, para se contrapor ao direito divino, à lei natural cristã. A secularização do direito, com a concepção do direito natural, fez nascer a ideia de direitos naturais do indivíduo ${ }^{1}$. No entanto, esse desenvolvimento foi lento, pois, num primeiro momento, a lei divina foi transferida para a do rei e, depois, para a aristocracia feudal, de modo que, apesar de já se ver a figura do homem como o fazedor de leis, os direitos ainda não eram inerentes a todos na sociedade ${ }^{2}$.

Contudo, a teoria contratual de Locke conduziu, como relata Canotilho ${ }^{3}$, “à defesa da autonomia privada, essencialmente cristalizada no direito à vida, à liberdade $\mathrm{e}$ à propriedade. Essa concepção do individualismo possessivo influenciará, em parte, decisivamente, a teoria liberal dos direitos fundamentais, que os considerará sempre como direitos de defesa do cidadão perante o Estado, devendo este abster-se da invasão da autonomia privada".

Assim nasceu o Estado Liberal, com os direitos dos indivíduos, pessoalmente considerados, levados ao maior grau de importância, especialmente no que concerne à liberdade, pois o que se tinha era um indivíduo livre para agir em sociedade, que encontrava como limite apenas a liberdade do outro. Esse momento histórico é aquele denominado dos direitos fundamentais de primeira geração, fundados, essencialmente, em liberdades negativas, por meio das quais o Estado deveria abster-se para que os indivíduos fossem livres.

No entanto, verificou-se, num momento posterior, que essa concepção de direito de liberdade do homem, enquanto indivíduo isolado na sociedade, não lhe era suficiente. Isso porque o homem efetivamente age em sociedade, de modo que as circunstâncias econômicas, políticas e sociais com ele interagem; dessa forma, ele passou a

\footnotetext{
${ }^{1} \mathrm{~V}$., sobre a evolução dos direitos naturais, em especial o nascimento dos direitos individuais e das liberdades fundamentais, CANOTILHO, J.J. Gomes. Direito Constitucional e Teoria da Constituição, $5^{\mathrm{a}}$ ed., Coimbra: Almedina, 2002, p. 378/388.

${ }^{2}$ Nesse sentido, Hobbes, tal qual Locke, em uma ideia inicial, previram o pacto social, no qual incrustrada estava a absolutização, ou seja, a existência de um soberano absoluto que detinha posições privilegiadas.

${ }^{3}$ CANOTILHO, J.J. Gomes. ...., Direito Constitucional...., Op. Cit., p. 382.
} 
necessitar da defesa de seus direitos nessas interações. Assim nasceram os direitos fundamentais de segunda geração, apontados como aquelas liberdades positivas, exigíveis do Estado.

No entanto, a sociedade continuou em transformação, o que provocou mudanças em todos os aspectos da atividade humana, determinando uma profunda alteração nas relações afetivas, econômicas, sociais, culturais e, como não poderia deixar de ser, em consequência das demais, também nas relações jurídicas.

A nova sociedade impôs a sua própria reestruturação, com base nos novos atores sociais, que não eram mais apenas os indivíduos isoladamente considerados, mas também aqueles inseridos nas classes sociais, religiosas e profissionais a que pertenciam, e, ainda, os indivíduos na condição de cidadãos e de coletividade ${ }^{4}$. Assim, os direitos e deveres das pessoas deixaram de ser as liberdades públicas e os direitos dirigidos tão somente a elas e emanados de suas atitudes, passando a lhes interessar os problemas do grupo, da classe, da cidade e do ambiente dos quais faziam parte, afastando os indivíduos "o interesse imediato, egoísta, para, com os olhos num ideal amplo e generoso, empenhar esforços comuns com vistas à consecução desse desiderato". Ou seja, os problemas deixaram de ser isolados para serem de grupo, de massa, percebendo os indivíduos que "pensar e agir coletivamente é passar a agir inteligentemente, porque a reunião dos esforços individuais é o instrumento mais eficaz para a consecução do fim comum",

Esse cenário, totalmente diverso daquele que predominou até o Estado Liberal, impôs a reestruturação de toda a sociedade, no que se incluiu o sistema jurídico, que teve que se adequar à nova classe de direitos - de massa - emergentes dessa nova

\footnotetext{
${ }^{4}$ De acordo com Mauro Cappelletti, no século XIX, percebeu o indivíduo a necessidade de "romper a cadeia" de sua debilidade diante do poder indústria (CAPPELLETTI, Mauro. "Formações sociais e interesses coletivos diante da Justiça Civil", Tradução portuguesa do original italiano por Nelson Renato Palaia Ribeiro de Campos, in Revista de Processo, São Paulo, n. 5, jan-mar/1977, p. 148/149).

Interessante a anotação de Diogo Maia sobre o conceito de classe. Para a finalidade desse estudo, ela não pode ser vista somente pelo seu ângulo objetivo, como um "conjunto humano que pode ser reunido sob uma classificação segundo um critério objetivo", ideia que vigia nos períodos antigo e medieval. Faz-se necessário agregar ao conceito uma carga subjetiva, "aduzindo a noção de consciência de si próprio como um grupo autodeterminado", consciência essa que passou a existir somente na era industrial moderna (MAIA, Diogo Campos Medina. Ação Coletiva Passiva. Rio de Janeiro: Lumen Juris, 2009, p. 11/12).

${ }^{5}$ Cf. MANCUSO, Rodolfo de Camargo. Interesses Difusos - Conceito e legitimação para agir. $6^{\mathrm{a}}$ ed., revista, atualizada e ampliada. São Paulo: RT, 2004, p. 55.
} 
condição social ${ }^{6}$. Tornou-se clara, diante disso, a dimensão social dos novos direitos emergentes dessa condição, pois esses integravam uma "comunidade compartilhando de suas necessidades e seus anseios", como, com maestria, aponta Grinover ${ }^{7}$. Diante disso, como anota a autora, criou-se uma nova forma de gestão da coisa pública, com uma gestão participativa, de racionalização do poder.

Assim nasceram os direitos de terceira geração, representados pelos direitos de solidariedade, decorrentes dessa nova percepção do indivíduo no meio social e na comunidade em que vive. Não há dúvidas de que esse passo foi bastante relevante para o Direito, à medida que houve uma releitura do Estado Moderno para alcançar o Estado Pós-Moderno, social e globalizado. Nesse ponto da evolução, o direito acaba restando até mesmo mais importante que as leis, porque aquele deve se tornar "livre dos excessos positivistas e distante de um processo de conformação social e individualista" ${ }^{\text {. }}$.

A sociedade marcada pela concepção liberal individualista teve dificuldade inicial considerável de entender como direito aquele pertencente a toda a coletividade generalizada, ou seja, a todos os indivíduos, mas não a um especificado. Essa problemática, como adiante se verá, encontra-se hoje resolvida, havendo um consenso generalizado de que o interesse social pode ser considerado e tutelado como efetivo direito ${ }^{9}$.

E foi exatamente com base nesse cenário que nasceram os direitos coletivos, muitas vezes pertencentes a toda a sociedade de maneira difusa, mas, ao mesmo, tempo, titularizado por todos os indivíduos. Barbosa Moreira ${ }^{10}$, em estudo realizado em 1983, deixou transparecer a aparente carga de estranheza que a doutrina revelou, em um

\footnotetext{
${ }^{6}$ V. CAPPELLETTI, Mauro. "Formações sociais e interesses .....", Op. Cit., p. 130.

${ }^{7}$ GRINOVER, Ada Pellegrini e outros. Os Processos Coletivos nos Países de Civil Law e Common Law: uma análise de direito comparado, São Paulo, RT, 2008, p. 229/230.

${ }^{8}$ V. ADAMOVICH, Eduardo Henrique Raymundo von, "A Justiça Geométrica e o Anteprojeto de Código de Processos Coletivos: elementos para uma justificativa histórico - filosófica, ou por uma visão atual do alcance e da função criadora da jurisdição coletiva", in GRINOVER, Ada Pellegrini e outros (coord.). Direito Processual Coletivo e anteprojeto de Código Brasileiro de Processos Coletivos, São Paulo, RT, 2007, p. 56.

${ }^{9}$ O Professor Kazuo Watanabe deixa assente a solução dessa problemática, anotando que, "hoje, com a concepção mais larga do direito subjetivo, abrangente também do que outrora se tinha como mero 'interesse' na ótica individualista então predominante, ampliou-se o espectro da tutela jurídica e jurisdicional" (WATANABE, Kazuo, "Disposições gerais", in Código Brasileiro de Defesa do Consumidor comentado pelos Autores do Anteprojeto, GRINOVER, Ada Pellegrini e outros (coord.), 6 a ed., Rio de Janeiro, Forense, 1999, p. 719).

${ }^{10}$ BARBOSA MOREIRA, José Carlos. "Tutela constitucional dos interesses coletivos ou difusos". In Temas de Direito Processual, $3^{\text {a }}$ série. São Paulo: Saraiva, 1984, p. 194.
} 
momento inicial, em face desses direitos. Pedindo-se vênia para transcrever, o eminente jurista afirmou que "em vista, com efeito, de maneira precípua, interesses comuns a uma coletividade de pessoas não necessariamente ligadas por um vínculo jurídico bem definido. Tal vínculo pode até inexistir, ou ser extremamente genérico, reduzindo-se eventualmente à pura e simples pertinência à mesma comunidade política; e os interesses de cuja proteção não se cogita não surgem em função dele, mas antes se prendem a dados de fato, muitas vezes acidentais e mutáveis: existirão, por exemplo, para todos os habitantes de determinada região, para todos os consumidores de certo produto, para todos os que vivam sob tais ou quais condições sócioeconômicas, ou se sujeitem às consequências deste ou daquele empreendimento público ou privado, e assim por diante".

Estão inseridos nessa manifestação diversos conceitos que são inerentes aos direitos coletivos, bem como o alcance deles na sociedade. Não há dúvidas quanto à necessidade, cada vez mais premente, de se estudarem esses direitos e, mais do que isso, de se criarem mecanismos processuais adequados - o processo coletivo - à defesa do cidadão, do homem social, que, até há muito pouco tempo, era figura inexistente no cenário jurídico e vem galgando espaço na defesa dessa condição ${ }^{11}$.

Diante disso, neste estudo, antes de se adentrar seu objeto central, de cunho processual, impõe-se a realização de uma breve análise dessa sorte de direitos e do porquê de serem tutelados de forma coletiva, apontando-se os objetivos e os benefícios dessa modalidade de tutela.

\subsection{Os chamados direitos coletivos}

\footnotetext{
${ }^{11}$ Relativamente ao ocorrido no Brasil, o Ministro do Superior Tribunal de Justiça Teori Zavascki observou essa evolução dos instrumentos de tutela. Anotou ele que o processo civil clássico passou por diversas ondas renovatórias, que tiveram que ser acompanhadas por reformas legislativas. Isso porque "a estrutura original do Código de 1973, moldada para atender demandas entre partes determinadas e identificadas, em conflitos tipicamente individuais, já não espelha a realidade do sistema do processo civil" (ZAVASCKI, Teori Albino. Processo Coletivo - Tutela de Direitos Coletivos e Tutela Coletiva de Direitos, $3^{\mathrm{a}}$ ed. Revista, atualizada e ampliada, São Paulo, RT, 2008, p. 22).

Nesse mesmo sentido, em trabalho publicado em 1989, Cappelletti já anotava que "the trend is also to diversify judicial bodies and procedures greatly, to make them instruments for social progress rather than blind conservatism, and to free them of the formalistic, expensive, time-consuming, and ideologically out moded features which so frequently characterize traditional courts and their procedures. (...) The principal issues of our day no longer involve an essentially individualistic static 'private law' and its "droits subjectifs", but rather reflect the problems of an industrial, dynamic, pluralistic society", pelo que anotava a necessidade de mudança de órgãos e procedimentos judiciais (CAPPELLETTI, Mauro. The judicial process in comparative perspective. Oxford; New York : Clarendon Press, 1989, p. 236).
} 
No ordenamento jurídico brasileiro, atendendo à já referida mudança no espectro social do indivíduo, a Constituição Federal de 1988 trouxe um grande avanço no tocante à proteção de direitos, elencando, em seu artigo $5^{\circ}$, os direitos e deveres não só individuais, mas também aqueles coletivos, consoante se depreende já da enunciação do capítulo em que se insere a norma ${ }^{12}$. Além disso, consoante ressalta Mancuso, a Constituição Federal trouxe outros elementos a "impulsionar a linha evolutiva do nosso processo coletivo", mencionando a positivação de importantes valores metaindividuais (como meio ambiente - artigo 225, patrimônio cultural - artigo 216, consumidores - artigo 170, V, política urbana - artigo 182), a instauração de uma democracia participativa, ao prever a legitimação do Ministério Público para a tutela de direitos coletivos, o credenciamento de entidades associativas (artigo $\left.5^{\circ}, \mathrm{XXI}\right)$, de sindicatos (artigo $8^{\circ}$, III) a previsão do mandado de segurança coletivo (artigo $5^{\circ}, \mathrm{LXX}, b$ ), a autorização para um rol de entes públicos para promover ação direta de inconstitucionalidade (artigo 103) ${ }^{13}$.

É importante salientar que a referência a direitos coletivos deve ser entendida de modo amplo, para abarcar não só aqueles direitos coletivos propriamente ditos, ou seja, não só aqueles direitos pertencentes a uma determinada classe, que são os direitos ordinariamente tidos como coletivos. O que se pretende, ao conferir-se tutela aos direitos coletivos, é, de igual modo, a proteção dos direitos difusos e dos individuais homogêneos, categorias inseridas no que, de modo amplo, se denomina "direitos coletivos", como se verá neste trabalho.

Assim, o inciso XXXV, do artigo $5^{\circ}$, da Constituição Federal, alinhando-se à própria enunciação do capítulo em que se insere, estabeleceu a proteção, pelo Judiciário, de qualquer lesão ou ameaça a direito, não mais se referindo apenas aos direitos individuais. Por conta disso, fez-se necessária a criação de mecanismos processuais para que os direitos coletivamente considerados pudessem ser apreciados pelo sistema jurídico, para garantir, desse modo, o amparo que lhes foi assegurado pela Carta Magna.

\footnotetext{
${ }^{12}$ Constituição Federal, Título II (Dos Direitos e Garantias Fundamentais), Capítulo I (Dos direitos e deveres individuais e coletivos).

${ }_{13}$ V. MANCUSO, Rodolfo de Camargo. Jurisdição coletiva e coisa julgada: teoria geral das ações coletivas. $2^{\mathrm{a}}$ ed. São Paulo: RT, 2007, p. 57.
} 
Nesse sentido, no próprio artigo $5^{\circ}$ da Constituição Federal, em seu inciso LXX, previu-se a possibilidade de impetração de mandado de segurança coletivo, por partidos políticos, organizações sindicais, entidades de classe ou associações, para tutela de direitos de seus membros.

Ainda antes da entrada em vigor da Constituição Federal de 1988, que conferiu dignidade maior à proteção aos direitos coletivos no Brasil, outras disposições legais, já atentando para as modificações sociais e para o que ordenamentos outros traziam sobre o tema, como adiante se verá, passaram a conferir proteção a esses direitos. Por primeiro, a ação popular, prevista pela Lei n. 4.717/65, foi criada com o objetivo de possibilitar ao próprio cidadão a defesa de direitos de natureza coletiva. Após, mas ainda antes da Carta Constitucional de 1988, foi editada a Lei n. 7.347/85, a chamada Lei da Ação Civil Pública, como forma de regulamentar, principalmente, a defesa do meio ambiente, do patrimônio cultural, do erário público e dos consumidores.

Posteriormente, foi criada a Lei n. 8.078/90, o denominado Código de Defesa do Consumidor, que dispôs sobre a proteção do consumidor, estabelecendo os direitos e deveres dos consumidores e dos demais participantes das relações de consumo, bem como trazendo regras processuais quanto ao modo de proteção do consumidor em juízo, tanto individualmente, como de maneira coletiva.

Esse último diploma legal foi de máxima importância, pois, além de trazer disposições substanciais e processuais essenciais aplicáveis a toda a sorte de direitos coletivos e a todos os meios processuais aptos a sua tutela, trouxe dispositivo de classificação desses direitos, assim entendidos em sentido lato, fixando o objeto material do direito processual coletivo.

Não há consenso quanto aos benefícios da positivação das várias espécies de direitos coletivos. Os críticos apontam a desnecessidade da previsão, especialmente porque não há restrição quanto aos direitos materialmente tuteláveis, de modo que não haveria razão para a lei estabelecer conceitos classificatórios ${ }^{14}$.

\footnotetext{
${ }^{14}$ A restrição aos direitos materialmente tuteláveis não é imposta pela lei, o que se coaduna com o Estado Democrático de Direito. Todavia, a jurisprudência brasileira afastou a possibilidade de tutelar coletivamente matérias tributárias e previdenciárias, o que revela um retrocesso.
} 
Ademais, é de se ter presente, ao que se observa pelo histórico de evolução da sociedade, tanto em termos econômicos quanto científicos e tecnológicos, e, por consequência, evolução dos direitos hoje passíveis de tutela, que essa classificação não venha a ser adequada daqui a alguns anos, de maneira que se propiciaria uma nova discussão quanto ao cabimento de tutela de novos "interesses" que eventualmente não se encaixem na conceituação hoje existente ${ }^{15}$.

No entanto, em vista da ausência de consenso doutrinário a respeito, preferiu o legislador estabelecer aqueles conceitos que lhe eram mais adequados, o que foi extremamente importante para que eles pudessem ter aplicação no Brasil, pois, se assim não fosse, o pensamento do jurista de civil law, como salientou o próprio Gidi em sua crítica aqui anotada, não teria conseguido com eles trabalhar. Mas é certo que, se desenvolvido o processo coletivo no Brasil, de forma a se absorverem os seus conceitos, poderia se cogitar da supressão do rol legal, mas, por ora, não se pode tê-lo como inadequado. Ademais, não se pode deixar de anotar que a divisão entre os diversos tipos de direito é, atualmente, relevante para se verificar a extensão dos limites da coisa julgada da decisão a ela relativa, uma vez que ela é diversa de acordo com a espécie de direito tratada, conforme se verá no capítulo 5.

Assim, o artigo 81 do Código de Defesa do Consumidor estabelece:

\footnotetext{
${ }^{15}$ Dentre aqueles que criticam o estabelecimento dos conceitos, ressalta-se Márcio Flávio Mafra Leal, que, em crítica ao então existente Anteprojeto de Código de Processos Coletivos, afirmou que esse não deveria prosseguir na definição dos direitos. De acordo com o autor, como não há restrição dos direitos materialmente tuteláveis pela ação, deveria caber à doutrina e não à lei o estabelecimento desses conceitos. De acordo com o autor, os conceitos são úteis e corretos, mas eles são decorrência das regras do funcionamento da sentença coletiva e não sua condição, de modo que, para se propor uma ação, "bastaria definir legalmente quem são os legitimados e as regras para a extensão ou dimensão dos comandos da sentença" (LEAL, Márcio Flávio Mafra, "Anteprojeto de Código Brasileiro de Processos Coletivos Aspectos políticos, econômicos e jurídicos", in GRINOVER, Ada Pellegrini e outros (coord.). Direito Processual Coletivo e anteprojeto de Código Brasileiro de Processos Coletivos, São Paulo, RT, 2007, p.76.). Também critica o estabelecimento estancado dos direitos Gidi, que, apesar de anotar a mestria intelectual da classificação, aduz ser ela inútil ou, talvez, até impeditiva da consecução de direitos. Nesse sentido, ressalta que "é inegável que a criação de tais figuras teóricas dá uma certa aparência de legitimidade ao instituto para o jurista de civil law, habituado a operar o direito através de instrumentos conceptuais, como o 'direito subjetivo' ou o 'interesse legítimo'. Nesse ponto, o legislador não poderia ter sido mais preciso. Todavia, fazendo minha a crítica de Zechariah Chafee Jr. [Some problems of equity, Ann Arbor: University of Michigan Press, 1950], se no futuro, em face da evolução das relações sociais, aparecer uma quarta situação onde a tutela coletiva seja desejável, não haverá qualquer dispositivo legal que a autorize". (GIDI, Antonio. A Class Action como instrumento de tutela coletiva dos direitos. As ações coletivas em uma perspectiva comparada. São Paulo: RT, 2007, p. 69).
} 
"Art. 81. A defesa dos interesses e direitos dos consumidores e das vítimas poderá ser exercida em juízo individualmente, ou a título coletivo.

Parágrafo único. A defesa coletiva será exercida quando se tratar de: I - interesses ou direitos difusos, assim entendidos, para efeitos deste código, os transindividuais, de natureza indivisível, de que sejam titulares pessoas indeterminadas e ligadas por circunstâncias de fato; II - interesses ou direitos coletivos, assim entendidos, para efeitos deste código, os transindividuais, de natureza indivisível de que seja titular grupo, categoria ou classe de pessoas ligadas entre si ou com a parte contrária por uma relação jurídica base;

III - interesses ou direitos individuais homogêneos, assim entendidos os decorrentes de origem comum".

É de se observar que essa classificação não é exclusivamente afeita ao direito processual, pois, antes disso, toca ao direito material, já que os mencionados direitos e interesses existem, antes de no processo, no plano sociológico, de maneira que, ainda que não se promova um processo para sua tutela, os direitos já existem, independentemente disso. E o Projeto de Lei n. 5.139/09 manteve a definição de cada espécie de direito coletivo, repetindo, em termos amplos, em seu artigo $2^{\circ}$, o que consta no transcrito dispositivo do Código de Defesa do Consumidor. A única distinção é que, no artigo $1^{\circ}$ do Projeto, elencaram-se, de modo não taxativo, porque expressamente se deixou espaço para outros interesses (inciso V), espécies de bens que poderiam submeter-se à tutela coletiva, como meio ambiente, saúde, consumidor, idoso, ordem social, bens históricos, dentre inúmeros outros. Esse rol, além de servir de base para a aplicação da lei e a atuação do processo, revela a natureza material da classificação.

Os conceitos legais estabelecidos pelo Código de Defesa do Consumidor mostram-se especialmente relevantes por força de dispositivo legal inserido no próprio diploma consumeirista, por meio do qual as disposições nele contidas aplicamse a qualquer sorte de direitos transindividuais, não só aqueles relativos às atividades de 
consumo. Assim, é também essa a classificação aplicável aos direitos protegidos pela ação civil pública e pelos demais remédios processuais previstos no ordenamento.

Outrossim, é necessário observar-se que, no texto legal, o termo "interesse" é tratado como sinônimo de "direito", estancando divergência que há muito existia, como anteriormente se anotou. Isso porque havia muitos questionamentos, antes disso, quanto à possibilidade de tutela jurisdicional de "interesses", que não eram considerados "direitos subjetivos", tais quais então compreendidos pelo ordenamento jurídico. Os direitos subjetivos sempre foram entendidos como "a faculdade, assegurada por lei, de exigir determinada conduta (ação ou omissão) de alguém, que, por lei ou por ato ou negócio jurídico, está obrigado a observá-la"16, a partir de que se constata existir grande centralização na figura do indivíduo ${ }^{17}$. O ilustre jurista português Canotilho ${ }^{18}$, ao tratar dos direitos, liberdades e garantias, anota que, diante de sua definição, esses seriam os direitos com referência pessoal ao homem individual ("radical subjectivo"). No entanto, o autor ressalta não ser esse um critério constitucionalmente adequado, já que a própria Constituição, no caso a portuguesa, que traz disposições semelhantes às da brasileira nesse sentido, inclui os direitos coletivos dentre os dignos de proteção.

Assim, a classificação de direito subjetivo, pelos ordenamentos de origem romano-germânica, é extremamente individualista. Por conta disso, foi muito difícil, especialmente para alguns dos tipos de direitos coletivos, a aceitação plena, pela doutrina e pelos aplicadores do direito, quanto à efetiva possibilidade de tutela desses direitos. No entanto, a questão encontra-se superada, muito por força do disposto no Código de Defesa do Consumidor, que estancou qualquer dúvida existente e eliminou a possibilidade de entendimentos distintos dos Tribunais quanto a esse aspecto ${ }^{19}$. Daí a

${ }^{16}$ Cf. GUSMÃO, Paulo Dourado de. Introdução ao Estudo do Direito, $20^{\mathrm{a}}$ ed. Rio de Janeiro: Forense, 1997, p. 241.

${ }_{17}$ Como observa Lenza, no processo civil clássico, "a terminologia direito só poderia ser utilizada nas hipóteses onde se verificasse a proteção judicial de um interesse e o titular desse interesse (juridicamente protegido) fosse um sujeito determinado, ou, na terminologia adotada pela doutrina clássica, o indivíduo" (LENZA, Pedro, Teoria Geral da Ação Civil Pública. São Paulo: RT, 2003, p. 43).

${ }^{18}$ CANOTILHO, J.J. Gomes. Direito Constitucional ...., Op. Cit., p. 396/397.

${ }^{19}$ Antes mesmo da promulgação da Constituição Federal, em estudo sobre a tutela jurisdicional dos direitos difusos, Barbosa Moreira já levantara essa problemática, anotando que o conceito de "direito subjetivo" funciona, muitas vezes, como verdadeiro "leito de Procusto" para algumas relações jurídicas. Segundo o autor, tudo dependeria, então, da necessidade ou não do reconhecimento ou da negação do autêntico "direito subjetivo", e seria simplificada a questão - como, por fim, pelo Código de Defesa do Consumidor, o foi "caso se admita, pura e simplesmente, que se trata de um 'interesse difuso', tutelável como tal" (BARBOSA MOREIRA “Tutela constitucional ....", Op. Cit., p. 189). 
relevância, antes referida, da conceituação, sem o que talvez não se tivesse chegado a essa aceitação.

É importante deixar assente que a noção de direitos coletivos em sentido lato não se traduz no conceito de direito público, como já se cogitou e, às vezes, ainda causa alguma confusão na doutrina. $\mathrm{O}$ conceito de direito público deve se restringir àqueles direitos pertencentes ao Estado, ao ente público. São direitos subjetivos desse ente e não podem ser confundidos com os direitos coletivos, que, como adiante se verá, são aqueles pertencentes à coletividade ou a um grupo determinado ${ }^{20}$. Todavia, essa distinção não é observada com clareza pelos julgadores, que permitem, muitas vezes, a tutela de direitos públicos como se coletivos fossem.

Há muitas referências doutrinárias de que os direitos coletivos em sentido lato estariam no meio do caminho entre os direitos estritamente privados e o interesse público. Todavia, os que assim afirmam, certamente, não estão pensando no direito público, de determinado ente da Administração Pública, mas, sim, no significado social dessa sorte de direitos, haja vista que, em seu conceito, estão inseridas necessidades de toda a coletividade e a possibilidade de tutela em conjunto disso tudo, inclusive propiciando a organização do corpo social ${ }^{21}$.

Contudo, o significado não se encerra na questão social, pois também existe aquele sentido político, já que, por meio do exercício desse direito, é possível, inclusive, o controle das políticas públicas, haja vista que, nos dias atuais, não se pode ter como absoluta a separação de Poderes, que devem, ao contrário, harmonizarem-se, sendo, ao Judiciário, permitido, dentre outros fatores, o controle da moralidade administrativa, cuja realização não é possível, sem que se adentre o mérito do ato administrativo. Desse

\footnotetext{
${ }^{20}$ De acordo com Cappelletti, "modern societies bring to the forefront new rights and legitimate interests - a newer king of 'property' - which, although not 'public' in the Roman and civilian sense of the word (that is, belonging to the res publica or state) are colltective or difuse, in the sense that either they do not 'belong' to any individual in particular, or that individuals own only an insignificant portion of them" (CAPPELLETTI, Mauro. The judicial process ...., Op. Cit., p. 272/273).

21 V. OLIVEIRA, Swarai Cervone de. Poderes do juiz nas ações coletivas, dissertação de Mestrado defendida na Faculdade de Direito da Universidade de São Paulo em 2007, sob orientação do Professor José Rogério Cruz e Tucci, p. 38/49.

De acordo com Cappelletti, em estudo realizado em 1977, é necessário superar a dicotomia entre público e privado para se poder inclusive compreender os direitos coletivos (V. CAPPELLETTI, Mauro. "Formações sociais e ....", Op. Cit., p. 135)
} 
modo, o exercício dos direitos coletivos pode converter-se na própria afirmação do Estado Democrático de Direito.

Em minucioso trabalho sobre os interesses difusos, Rodolfo Mancuso ${ }^{22}$ explicita a diferença existente entre essas várias figuras comumente tratadas como sinônimas, tanto pelos leigos como pelos operadores do direito. Assim, deixa assente o Professor a diferença entre interesse social, geral e público, sendo o primeiro aquele "que interessa à sociedade ou é relativo a esta"; geral, aquele que toca a uma coletividade, ou seja, opõe-se a interesse individual; e público o pertencente ao Estado, o que pode ou não coincidir com um interesse social, pois a coletividade pode ter interesses exatamente contrários ao interesse estatal.

Dessa forma, pode-se dizer que o interesse coletivo em sentido lato é um direito social, já que toca a uma coletividade, mas não obrigatoriamente existirá relevância ou indisponibilidade desse direito para a sociedade, pois poderá ele ser apenas um interesse de um determinado grupo em face de seu violador comum. De igual modo, os direitos individuais homogêneos, exercidos de forma coletiva também não possuem a relevância social como pressuposto, já que basta a exigência de uma origem comum para que assim possam ser tutelados. Não se pode olvidar que "o fato de um interesse ser exercido por via individual ou coletiva não altera sua essência. A natureza de um interesse advém da finalidade à qual ele está afetado, e não da forma escolhida para seu exercício,"23. Assim, os direitos coletivos em sentido lato são, de fato, interesses sociais, mas não possuem dentre seus pressupostos intrínsecos a indisponibilidade ou a relevância. A tutela coletiva sim, em vista de seus inúmeros benefícios, que serão adiante analisados, deve ser presumida como de relevância social, como o faz o Projeto de Lei n. 5.139/09, no $\S^{\circ}$ de seu artigo $2^{\circ}$, o que não significa que os direitos materiais envolvidos necessariamente assim o sejam.

Ultrapassada essa problemática, estabeleceu, então, o Código de Defesa do Consumidor três espécies de direitos ou interesses coletivos por ele passíveis de tutela: os difusos, os coletivos em sentido estrito e os individuais homogêneos. Importante se anotar, porque o presente estudo trará várias reflexões e comparações com os sistemas de

\footnotetext{
${ }^{22}$ V. MANCUSO, Rodolfo de Camargo. Interesses ....., Op. Cit., em especial o capítulo 1, p. 19/81.

${ }^{23}$ V. MANCUSO, Rodolfo de Camargo. Interesses Difusos ....., Op. Cit., p. 28
} 
common law, que essa nomenclatura e mesmo essa subdivisão é totalmente estranha àqueles ordenamentos. Todavia, conforme ressalta Mullenix ${ }^{24}$, os conceitos trazidos sob esses significados têm correspondência histórica e aplicação contemporânea nos sistemas de common law, de modo que o estudo daquele ordenamento tem validade e interesse prático para nós. Além disso, a análise comparativa dos dois sistemas permite a evolução mútua de ambos, emprestando um ao outro o que é condizente com a estrutura social de cada ordenamento.

De acordo com o Código de Defesa do Consumidor, interesses ou direitos difusos (inciso I antes mencionado) são aqueles de natureza indivisível e que têm como titulares pessoas indeterminadas, ligadas por uma circunstância de fato, ou seja, sem a existência de uma relação jurídica base. Ademais, esses direitos não são fruíveis individualmente com exclusão de outros, de modo que, estando todos na mesma situação, gozam-nos de modo idêntico. Daí se afirmar a incapacidade de se determinarem seus titulares ${ }^{25}$.

A Professora Ada Pellegrini Grinover ${ }^{26}$ explicita, com objetividade, as características que os distinguem, que merecem ser aqui transcritas em vista de sua precisão: “indeterminados pela titularidade, indivisíveis com relação ao objeto, colocados no meio do caminho entre os interesses públicos e os privados, próprios de uma sociedade de massa e resultado de conflitos de massa, carregados de relevância política e capazes de transformar conceitos jurídicos estratificados, como a responsabilidade civil pelos danos

\footnotetext{
${ }^{24}$ MULLENIX, Linda e outros. Os Processos Coletivos nos Países de Civil Law e Common Law: uma análise de direito comparado, São Paulo, RT, 2008, p. 267. A autora explicita que os países de common law reconhecem os direitos dos grupos com interesses comuns para pleitearem a tutela coletiva, no que se incluem os direitos decorrentes de danos ambientais, proteção do consumidor, demandas atinentes à discriminação e ao trabalho, violações antitruste, dentre outros.

${ }^{25}$ O Professor Kazuo Watanabe traz importantes exemplos do que pode ser considerado um direito difuso, mencionando a publicidade enganosa ou abusiva, a colocação no mercado de produtos com alto grau de nocividade ou periculosidade à saúde ou segurança dos consumidores. Em ambos os casos a situação pode afetar um sem número de pessoas, ligadas por essa situação de fato, mas sem relação jurídica entre si (WATANABE, Kazuo, "Disposições gerais"...., Op.Cit., p. 720).

Outro exemplo clássico de direito difuso pode se dar na hipótese de uma ação coletiva promovida pelo Ministério Público em face de uma empresa poluidora do ambiente e emissora de ruídos acima dos níveis permitidos, visando à imposição, a essa empresa, de obrigação de não fazer. Trata-se de interesse difuso, porque diz respeito a pessoas ligadas por circunstâncias fáticas (por serem afetadas pela poluição e emissão de ruídos acima dos limites legais) (ARRUDA ALVIM, Eduardo, "Coisa julgada e litispendência no Anteprojeto de Código Brasileiro de Processos Coletivos", in GRINOVER, Ada Pellegrini e outros (coord.). Direito Processual Coletivo e anteprojeto de Código Brasileiro de Processos Coletivos, São Paulo, RT, 2007, p. 178).

${ }^{26}$ GRINOVER, Ada Pellegrini. Os Processos Coletivos ....., Op. Cit., p. 229.
} 
causados no lugar da responsabilidade civil pelos prejuízos sofridos, como a legitimação, a coisa julgada, os poderes e a responsabilidade do juiz e do Ministério Público, o próprio sentido da jurisdição, da ação, do processo". Anota a autora a dimensão social dessa sorte de direitos, exatamente o que justifica a sua tutela coletiva e o que agrega importância ao seu estudo, porque eles se refletem em todos aqueles que integram uma "comunidade compartilhando de suas necessidades e seus anseios".

Esses direitos são, na realidade, os que sofreram maior resistência de incorporação aos ordenamentos romano-germânicos, especialmente porque mais distantes do clássico conceito de direito subjetivo. Por não serem de ninguém, mas pertencerem a todos ao mesmo tempo, no plano prático, sua defesa pode acabar difundida e não exercida, porque não afeita a nenhuma pessoa em particular, daí porque se pensava em mero interesse e não em efetivo direito. Todavia, quando exercida a sua tutela adequada, não há dúvida de que são instrumentos de participação social efetiva e, também, meio político para a coletividade, pois constituem um instrumento a que se pode agregar muita força, inclusive perante o Poder Público ${ }^{27}$. Diante dessa força política, são referidos como direitos de alta carga de conflituosidade, porque sempre estarão envolvidos interesses antagônicos $\operatorname{complexos}^{28}$. É indiscutível que a previsão legal de sua tutela é benéfica a toda a sociedade e o que se vê hoje é a ampliação de sua proteção, ainda que, no Brasil, mediante uma preponderante atuação dos agentes estatais, o que adiante se analisará.

\footnotetext{
${ }^{27}$ Nesse ponto, interessante a observação de Mirra, no sentido de os direitos difusos e coletivos constituírem a verdadeira manifestação da sociedade contemporânea, de produção em série e consumo em massa, sendo resultantes de conflitos e lesões igualmente de massa, de modo que se situam entre os direitos públicos e aqueles privados. Esclarece, ainda, que "não se está diante, propriamente, de interesses públicos, assim entendidos aqueles que têm no Estado o titular único e exclusivo de sua tutela, já que, frequentemente, o próprio Estado aparece como o causador de lesões aos direitos individuais. Mas tampouco se trata de interesses privados disponíveis, pois os direitos difusos, em suas diversas manifestações, não são jamais a soma de direitos individuais e sim direitos pertencentes indivisivelmente a todos, marcados no mais das vezes pela característica da indisponibilidade" (MIRRA, Álvaro Luiz Valery, "Associações civis e a defesa dos interesses difusos em juízo: do direito vigente ao direito projetado", in GRINOVER, Ada Pellegrini e outros (coord.). Direito Processual Coletivo e anteprojeto de Código Brasileiro de Processos Coletivos, São Paulo, RT, 2007, p. 115).

${ }^{28}$ Nas palavras de Pedro Lenza, "esses demonstram, portanto, a alta conflituosidade dos interesses difusos, a sua 'intensa litigiosidade interna', característica inerente à sociedade de massa, que traz em seu bojo inevitáveis conflitos, também de massa, envolvendo, então, escolhas de caráter político.

Tendo em vista esta 'intensa litigiosidade interna' dos interesses difusos, o entrechoque de seus valores, orienta-se pela reestruturação do conceito clássico de lide, tão lembrada na concepção carneluttiana (conflito de interesses qualificado por uma pretensão resistida).

A resistência a um pretenso interesse difuso não reside no fato de existir uma outra pretensão em sentido antagônico. Como visto, o preterimento de uma pretensão dar-se-á em razão de escolhas políticas e não em decorrência de sua ilicitude" (LENZA, Pedro, Teoria ....., Op. Cit., p. 87/88).
} 
Relativamente aos direitos coletivos (inciso II), como se verifica da norma, estabeleceu-se a necessidade de existência de uma relação jurídica entre os titulares, pré-existente à lesão ou à ameaça do direito. Seus titulares são pessoas integrantes de determinada categoria ou classe, portanto, pessoas, no mínimo, determináveis. Outrossim, tal qual os direitos difusos, são indivisíveis. Esses são os direitos coletivos, assim entendidos pelo senso comum, ou seja, aqueles pertencentes a uma coletividade identificada. No entanto, para fins de proteção judicial, tanto os difusos, antes mencionados, como os individuais homogêneos, que se verá a seguir, pertencem ao gênero denominado direitos coletivos.

Essa sorte de direitos é de compreensão mais fácil e mais palpável, ainda que por aqueles presos ao conceito de direito subjetivo. Isso porque existe um direito, em seu sentido clássico, claramente identificado, distinto apenas por não pertencer a apenas uma pessoa, mas a várias pessoas em conjunto, determináveis ${ }^{29}$.

Por fim, os direitos individuais homogêneos (inciso III) são definidos como os de origem comum, mas pertencentes, isoladamente, a cada um dos indivíduos. Nesse caso, os direitos de cada um de seus titulares decorrem de uma mesma situação, mas podem repercutir de maneira distinta em relação a cada um dos envolvidos, de modo que eles não têm, necessariamente, a mesma identidade fática ou temporal ${ }^{30}$.

A Professora Ada anota que essa origem comum pode ser próxima ou remota, sendo exemplo do primeiro caso a queda de um avião, que vitima diversas pessoas;

\footnotetext{
${ }^{29}$ Exemplo dessa sorte de direitos são aqueles de trabalhadores de uma determinada fábrica em relação a seu empregador, quanto ao estabelecimento de condições dignas de trabalho, ou dos titulares de linha telefônica, em relação à empresa de telefonia, como ocorreu com as milhares de ações relativas à cobrança da assinatura básica. Nesses casos, existe uma relação jurídica base entre os titulares dos direitos e seu suposto ofensor e os indivíduos são, se não determinados, passíveis de determinação.

${ }^{30}$ Paschoal deixa assente o que é essa origem comum, anotando que ela "pode tanto se referir a uma situação fática ou jurídica, mas não implica a exigência de que os fatos causadores do dano tenham ocorrido ao mesmo tempo e na mesma localidade. Isto é, um mesmo fornecedor poderá praticar uma série de atos idênticos atentatórios aos direitos dos consumidores e, caso estes tenham os mesmos direitos lesados, considerar-se-á que a origem dos danos é comum, ainda que tenham se verificado em momentos distintos" (PASCHOAL, Maximiliam Fierro. A representatividade adequada na Ação Coletiva Brasileira (Lei da Ação Civil Pública e Código de Defesa do Consumidor), dissertação de Mestrado defendida em 2007, sob orientação do Professor Kazuo Watanabe, p. 79).

Exemplificando o conceito, o Professor Kazuo Watanabe ("Disposições Gerais" ....., Op. Cit., p. 724) anota que "as vítimas de uma publicidade enganosa veiculada por vários órgãos de pessoas de imprensa e em repetidos dias ou de um produto nocivo à saúde adquiridos por vários consumidores num largo espaço de tempo e em várias regiões têm, como causa de seus danos, fatos com homogeneidade tal que os tornam a "origem comum" de todos eles".
} 
e do segundo um dano à saúde decorrente de um produto potencialmente nocivo, que pode ter tido como causa próxima as condições pessoais ou seu uso inadequado. Salienta, por fim, que, "quanto mais remota for a causa, menos homogêneos serão os direitos" "31.

Essa sorte de direitos é denominada pela doutrina como acidentalmente coletiva, pois, em si, os direitos são eminentemente individuais e poderiam ser tratados de forma individual ou em litisconsórcio ativo, consoante o estabelecido no artigo 46 do Código de Processo Civil, que também prevê elementos de homogeneidade entre os direitos ou obrigações tuteladas, porque, tais quais os denominados direitos individuais homogêneos, aqueles tuteláveis em litisconsórcio igualmente podem ter elementos identificadores relacionados à existência da obrigação, à natureza da prestação devida ou ao sujeito passivo comum ${ }^{32}$. Todavia, recebem o tratamento processual coletivo por esse ser-lhes mais vantajoso para os envolvidos e para a própria efetividade da Justiça ${ }^{33}$, consoante adiante se analisará, ao se tratar das razões que levam à tutela coletiva dos direitos.

Uma das maiores dificuldades para o desenvolvimento do processo coletivo, é, justamente, a tutela coletiva dos direitos individuais homogêneos. O processualista civil clássico, em sua ótica individualista, tem receio de admitir, de modo amplo e em detrimento dos indivíduos, a validade dos comandos coletivos em relação a esses direitos, o que será tema de especial abordagem neste trabalho. Assim, pode-se dizer que o tratamento coletivo dos direitos individuais homogêneos é o que representa maior desafio para os operadores do direito.

No que se refere aos direitos envolvidos, importante deixar assente que essa classificação é assim especialmente nos países ibero-americanos, pois há muitos

\footnotetext{
${ }^{31}$ V. GRINOVER, Ada Pellegrini, Da class action for damages à ação de classe brasileira: os requisitos de admissibilidade", in Revista Forense, n. 352. Rio de Janeiro: Forense, 2000, p. 10.

${ }^{32}$ V. ZAVASCKI, Teori Albino. Processo Coletivo ....., Op. Cit., p. 165/166.

${ }^{33}$ Ressalte-se que o tratamento coletivo dessa sorte de direitos ocorre somente até a fase condenatória, não ocorrendo quando da execução do comando judicial. Isso porque a sentença é genérica, estabelecendo apenas o dever de reparar, e cada indivíduo titular do direito deve liquidá-la separadamente, atendendo às circunstâncias e aos danos individuais, de modo que o tratamento coletivo tem essa limitação temporal, em vista da natureza do direito discutido.

O Projeto tenta afastar a necessidade dessa liquidação autônoma, por cada um dos prejudicados, prevendo, em seu artigo 26, que, na ação que tenha por objeto condenação ao pagamento de quantia em dinheiro aos individualmente prejudicados, deverá o juiz, impor a satisfação da obrigação de ofício, independentemente de execução, utilizando-se de formas coercitivas para tanto, como multas e afins.
} 
outros países que não possuem qualquer previsão de tutela de direitos difusos ou de individuais homogêneos. Consoante Relatório Geral elaborado por Grinover por ocasião do XIII Congresso Mundial da Associação Internacional de Direito Processual, especificamente no que toca à União Europeia, cujo relatório foi elaborado por Sergio Chiarloni, a União Europeia se preocupa, relativamente aos direitos coletivos, a partir de apenas um ponto de vista particular, o dos consumidores ${ }^{34}$.

No entanto, anota a Professora Ada, nas conclusões de seus relatórios, que o caminho evolutivo, que aponta ser mais que uma tendência, "mostra a consciência cada vez mais acentuada de que o objeto da tutela coletiva deve abranger quer os direitos difusos e coletivos, de titularidade indeterminada, coletivos por natureza, quer os individuais, pertencentes aos membros do grupo, quando homogêneos" ${ }^{\text {,35 }}$. E realmente não se podem ter dúvidas da relevância da tutela de todas as espécies de direitos do gênero coletivo, em vista do princípio da universalidade da tutela jurisdicional e, especialmente, do crescimento da figura do indivíduo como cidadão, como membro de grupos e como atuante na sociedade de massa, situações das quais emergem direitos de várias ordens que necessitam ser tutelados.

Observe-se, outrossim, como resta claro pelos conceitos trazidos pela lei, que um mesmo fato pode gerar violação às três espécies de direitos: difusos, coletivos e individuais homogêneos. Teori Zavascki deixa assente essa possibilidade, especificando que a tutela do meio ambiente e do consumidor trazem exemplos clássicos da ocorrência. Menciona, assim, a proteção do consumidor contra publicidade enganosa, anotando que, enquanto não ocorrer, concretamente, nenhum evento lesivo, esse direito é difuso, mas a partir da identificação de um dano material haverá direito individual homogêneo, porque serão determinados os indivíduos que sofrerão a lesão ${ }^{36}$. Desse modo, a espécie de direito buscada numa eventual demanda só poderá ser identificada a partir dos elementos da causa de pedir e do pedido, os quais, então, emergem, nos processos coletivos e com especial relevância, até porque, dependendo do direito versado, distintas serão as consequências do

\footnotetext{
${ }^{34}$ Nas palavras do relator Sergio Chiarloni, a União Europeia "non si occupa né di interessi diffusi (volendosi intendere questi ultimi come interessi che appartengono alla generalità dei cittadini, ad esempio l'interesse alla salubrità dell'aria), né di altre categorie di interessi collettivi appartenenti a più ristrette categorie di soggetti (ad esempio gli interessi dei lavoratori)" (V. Relatório da União Europeia que especifica os direitos tutelados e traz panorama geral sobre a tutela dos direitos em GRINOVER, Ada Pellegrini e outros. Os Processos Coletivos ...., Op. Cit., p. 19/24).

${ }^{35}$ GRINOVER, Ada Pellegrini e outros. Op. Cit., p. 235.

${ }^{36}$ V. ZAVASCKI, Teori Albino. Processo Coletivo ......, Op. Cit., p. 44/46.
} 
julgamento da demanda, no tocante à extensão subjetiva dos efeitos da decisão, conforme se abordará no capítulo 5 deste estudo ${ }^{37}$.

\subsection{Tutela coletiva dos direitos}

Apresentados os direitos transindividuais, em suas várias espécies, fazse necessário verificar como eles podem ser tutelados de maneira coletiva, ou seja, quais os meios disponíveis pelo ordenamento para a tutela coletiva dos direitos e o porquê de se fazer necessária - ou de ser preferencial - essa modalidade de tutela. A análise dos objetivos da tutela revela-se importante, pois somente diante do estabelecimento de finalidades claras, será possível, nos capítulos subsequentes, falar-se em eficácia da tutela, haja vista que a eficácia de determinado ato é uma circunstância que somente pode ser analisada à luz dos objetivos desse ato.

Nesse passo, a grande preocupação deve centrar-se na efetividade da proteção desses direitos. De nada adiantaria o seu reconhecimento enquanto verdadeiros direitos, e não mais meros interesses, impossíveis de serem judicialmente tutelados, ou a especificação legal do que eles venham a ser, se o ordenamento jurídico não dispusesse de formas concretas para sua proteção. E é certo que os mecanismos processuais criados para a defesa de interesses individuais, os direitos subjetivos dos indivíduos, não se mostram adequados para tanto, pois partem de uma perspectiva eminentemente individual ${ }^{38}$.

\footnotetext{
${ }^{37}$ Nesse ponto, importante anotar, porque se veem manifestações doutrinárias em sentido contrário, que os direitos em si não são distinguidos pela causa de pedir e o pedido, mas esses só servem para identificar qual direito está sendo colocado sub judice. Os direitos existem antes, a partir da sua infração ou do perigo de sua violação, sendo apenas identificados internamente no processo por meio desses elementos (Cf. ZAVASCKI, Teori Albino. Processo Coletivo ....., Op. Cit., p. 38/39).

${ }^{38}$ Conforme ressalta Cappelletti, a massificação da economia conduz à massificação da sociedade e essa à massificação do direito. "More and more frequently the complexity of modern societies generates situations in which a single human action can be beneficial or prejudicial to large numbers of people, thus making entirely inadequate the traditional scheme of litigation, as merely a two-party affair". "The new social, collective, 'diffuse' rights and interests can be protected only by new social, collective, 'diffuse' remedies and procedures” (CAPPELLETTI, Mauro. The judicial process ...., Op. Cit., p. 270-272).

Na lição de Fiss, "o axioma da participação individual é baseado em uma realidade que já não existe, qual seja a que comportava uma sociedade horizontalizada, em que as pessoas relacionavam-se umas com as outras em termos individuais e aproximadamente unitários", pois as normas contratuais eram vistas como o direito. Recorda o autor que "nossa realidade, entretanto, é vertical; o mercado foi substituído pela hierarquia e o empreendedor individual por departamentos públicos", pelo que é necessário estabelecerem-se centros de poder com força e recursos iguais aos dos agentes sociais dominantes, haja vista que a concepção individual deixa o indivíduo sem o suporte necessário (FISS, Owen. Um novo Processo Civil: estudos norte-americanos sobre jurisdição, constituição e sociedade. São Paulo: RT, 2004, p. 85/86).
} 
Como antes se ressaltou, os direitos coletivos possuem alta carga social, pois, à medida que se afastam do isolamento individual, tornam-se verdadeiros instrumentos de participação popular. Aliás, esse é um dos sentidos da tutela coletiva, o de permitir que a própria sociedade aja na proteção de seus direitos. Infelizmente, isso se encontra ainda um pouco distante no Brasil, pois a defesa dos interesses coletivos dá-se, em sua maior parte, pelo Ministério Público, entidade pública a que se confere legitimidade para tanto. Esse assunto será abordado em capítulo posterior neste estudo, mas, desde logo, é imperioso se ressaltar que seria saudável que a atuação popular fosse mais presente e efetiva, por meio da organização da sociedade, o que se acredita seja possível ocorrer com o desenvolvimento dos processos coletivos em nosso ordenamento e com a conscientização da população quanto à importância de sua atuação.

Nesse sentido, os princípios mais evidentes do direito processual coletivo são o acesso à justiça, por meio do qual se busca alcançar a tutela efetiva dessa sorte de direitos; a universalidade da jurisdição; a participação, que se dá não individualmente, mas por meio dos legitimados (participação "pelo processo", não "no processo", ou seja, por meio do exercício pleno do contraditório, com as garantias a ele inerentes); e a economia, consistente no máximo de resultado com o mínimo de emprego de atividades ${ }^{39}$.

Não há dúvidas de que se incrementa em muito o acesso à justiça, garantindo a universalidade da jurisdição, por meio da tutela coletiva dos interesses mencionados. Não se pode olvidar que muitos dos direitos envolvidos são aqueles pertencentes a ninguém especificamente, de maneira que os indivíduos não se mostrariam interessados e não atuariam em favor de sua proteção ${ }^{40}$. Assim, o agir coletivo revela-se mais forte e, portanto, mais eficaz, atendendo, como ressalta Mancuso, a uma exigência de otimização e racionalização do trabalho, da produção ou do exercício de um poder político,

\footnotetext{
${ }^{39}$ Cf. GRINOVER, Ada Pellegrini, "Direito Processual Coletivo", in GRINOVER, Ada Pellegrini e outros (coord.). Direito Processual Coletivo e anteprojeto de Código Brasileiro de Processos Coletivos, São Paulo, RT, 2007.

${ }^{40}$ Gidi recorda que também são beneficiadas pelos processos coletivos as pessoas hipossuficientes, que, às vezes, sequer sabem que seus direitos foram violados ou não possuem iniciativa e estrutura para sua defesa, além, é claro, de possibilitar-se a defesa de minorias, em condições semelhantes (GIDI, Antonio. A Class Action como ...., Op. Cit., p. 31/32).
} 
por meio da participação dos cidadãos, de modo que se leve ao reconhecimento de uma sociedade pluralista, numa democracia participativa ${ }^{41}$.

De igual modo, ainda quanto ao acesso à justiça, tem-se a ocorrência de danos difusos e individualmente muito pequenos, que, isoladamente, não se mostram vantajosos para os indivíduos perseguirem-nos. Ou seja, se a tutela desses direitos fosse eminentemente individual, muitas pessoas sequer enfrentariam o custo financeiro e psicológico para a proteção dessa sorte de direitos. No entanto, apesar disso, para o agente causador dos danos, acumulados, eles podem ser de grande monta e de repercussão econômica considerável. Daí a necessidade de serem protegidos em conjunto, para que se tenha força perante o agente causador do dano, evitando a impunidade dos responsáveis, até porque esses, diante de uma única sentença individual, podem até ignorar o alerta da sociedade a respeito de sua conduta danosa e nela persistir.

No entanto, a tutela coletiva dos direitos não somente é benéfica aos autores, mas também, em tese, aos réus, no que toca à economia processual. Isso porque, mesmo num caso de procedência do pedido, o desgaste desse réu com apenas um processo, ainda que mais longo, mais complexo e mais trabalhoso, será sempre menor do que aquele havido com centenas de outros processos individuais, de modo que se lhe permite angariar forças e recursos financeiros para sua defesa com maior rigor. Assim, o benefício da economia processual, tanto para o Estado-juiz, como para o autor ou mesmo o réu, é evidente $^{42}$.

A par desse aspecto, a segurança também é um princípio a ser considerado na tutela coletiva. Isso porque, por meio desse tipo de processo, evitam-se decisões contraditórias, que seriam possíveis caso existissem diversos processos

\footnotetext{
${ }^{41}$ MANCUSO, Rodolfo de Camargo. Interesses Difusos ..., Op. Cit., p. 42/43.

${ }^{42}$ Nesse sentido, ver observação de GIDI, Antonio. A Class Action como ...., Op. Cit., p. 26/27.

Paschoal, ao tratar das class actions norte-americanas, também ressalta essa finalidade, anotando que elas "propiciam a eficiência judicial, ao eliminar a necessidade de conflitos repetitivos e de reivindicações similares, reduzindo, inclusive, o custo dos litígios repetidos" (PASCHOAL, Maximiliam Fierro. A representatividade adequada ...., Op. Cit, p. 55).

É de se registrar que esse elemento benéfico do tratamento coletivo dos direitos só se torna completamente real para o requerido se a demanda coletiva, efetivamente, for capaz de encerrar a controvérsia, garantindolhe, por meio de um processo, o que ele só poderia obter caso se submetesse a, eventualmente, milhares de demandas de cada um dos titulares de direito individualmente considerados. Para tanto, nos capítulos subsequentes, serão analisados meios de se proceder a esse processo efetivo, também em relação ao réu.
} 
individuais sobre o mesmo assunto ${ }^{43}$. Esse é um dos maiores benefícios da tutela coletiva, pois, se corretamente trabalhado, pode reduzir a litigiosidade futura, com a multiplicação de demandas.

Num momento de grande crescimento das relações sociais, evitar-se decisões contraditórias deve ser considerado como um dos objetivos da tutela coletiva, pois o julgamento unitário do que seriam vários processos individuais proporciona se atinja um dos corolários mais importantes da Constituição Federal, que é a igualdade entre os cidadãos. Não se pode pensar em realização de justiça para apenas uma parcela da população ou para apenas parte dos integrantes de um grupo, pois isso acarretará um desequilíbrio social, prejudicando a classe que a ação coletiva visava a proteger.

Ademais, não só o aspecto da igualdade extrínseco ao processo, mas também aquele intrínseco é beneficiado. A isonomia entre as partes, mediante a colocação do indivíduo prejudicado no mesmo patamar do causador do dano, o que é dificilmente atingido sem as disposições processuais específicas da tutela coletiva, é outro princípio que resta ser observado com a tutela coletiva dos direitos ${ }^{44}$. Hoje, por força das garantias constitucionais, o Estado deve assegurar à coletividade o acesso à justiça, com igualdade de tratamento entre as partes, para a defesa de seus direitos em contraditório, dando-se publicidade aos atos processuais motivados e proferidos em lapso de tempo razoável. Tudo isso é mais facilmente atingido por meio do processo coletivo do que pelo individual. Esse aspecto é ainda considerado por disposições que estabelecem vantagens processuais como inversão de ônus da prova - a partes hipossuficientes, como são considerados os consumidores, no regramento a eles atinente.

Relativamente aos direitos difusos e coletivos, a necessidade de tratamento coletivo dos direitos é de mais fácil percepção. Isso porque, consoante se viu a partir das definições trazidas, esses direitos são indivisíveis, de maneira que precisam ser

\footnotetext{
${ }^{43}$ Gidi considera a eliminação do risco de decisões contraditórias um objetivo secundário, relegando para o acesso à justiça, à economia processual e à aplicação do direito material os objetivos principais (GIDI, Antonio. A Class Action como ...., Op. Cit., p. 25).

${ }^{44}$ Tucci aponta a importância dessa forma de tratamento dos direitos, esclarecendo que "o Direito Processual é moldado por duas diferentes exigências: precisão formal e justiça substancial. E nesse conflito dialético entre as exigências contrapostas, não obstante dignas de proteção, são inseridas as garantias constitucionais do processo nas Cartas Constitucionais dos Estados democráticos modernos" (TUCCI, José Rogério Cruz e. "Garantias Constitucionais do processo em relação aos terceiros", in Revista do Advogado, n. 99, AASP, set/08, p. 63).
} 
tratados unitariamente, de forma molecular. No caso dos difusos, isso é evidente, até porque os titulares não podem ser identificados, uma vez que são toda a coletividade. Nos coletivos propriamente ditos, apesar de terem sujeitos determináveis, a demanda coletiva mostra-se benéfica para se observarem, na prática, as diversas vantagens, antes descritas, na tutela coletiva dos direitos.

No entanto, a justificativa de tutela coletiva dos direitos individuais homogêneos é distinta, dado que a molecularização do direito não advém de sua necessidade intrínseca, haja vista ser ele apenas "acidentalmente coletivo", como antes se anotou, havendo até mesmo a possibilidade da existência de julgados diferentes para cada um de seus titulares, por tratar-se de relação jurídica diversa ${ }^{45}$.

Todavia, são inegáveis as vantagens do tratamento coletivo, tanto no que concerne ao aspecto de se evitarem decisões contraditórias, quanto relativamente à possibilidade de acesso à justiça de indivíduos que não trariam sua voz ao Judiciário. Além disso, não se pode jamais olvidar que, para a própria administração da Justiça, a atuação coletiva mostra-se benéfica, à medida que concentrará a solução de milhares, quiçá de milhões de problemas em um único processo, absorvendo o tempo e a energia de apenas um único juiz e de um único grupo de funcionários, evitando a pulverização de litígios de mesmo objeto ${ }^{46}$.

\footnotetext{
${ }^{45}$ Nesse sentido é o posicionamento de Barbosa Moreira, que explicita que "a disciplina unitária não deriva em absoluto de uma necessidade intrínseca", já que é exequível admitir, em tese, a possibilidade de resultados desiguais para os diversos participantes. No entanto, o autor já então observava, em 1983, que o ordenamento jurídico poderia estender a aplicação de técnicas coletivas a essa categoria, por motivos de conveniência, e o fez, por fim. (BARBOSA MOREIRA, José Carlos. "Tutela constitucional ....", Op. Cit., p. 196/197).

Nesse mesmo sentido é a opinião trazida por Teori Zavascki, que aponta que a distinção dessa sorte de direitos dos demais reflete-se no modo de sua tutela. Como aponta o autor, esses não são propriamente direitos coletivos, como antes se viu, mas são direitos que podem ser tutelados de forma coletiva, o que é diferente. É certo que possuem natureza diversa, pela própria divisibilidade, e que isso terá consequências, como aponta o autor, em relação à legitimidade para a propositura da ação, à coisa julgada e a diversos outros institutos processuais (ZAVASCKI, Teori Albino. Processo Coletivo ....., Op. Cit., p.37).

${ }^{46}$ Diversas anotações na doutrina deixam assente essa vantagem. Assagra de Almeida justifica que não é a natureza essencialmente coletiva do direito que faz com que determinada demanda possa ser considerada coletiva e também não é com base no direito posto sob exame que se afere se se trata ou não de espécie de tutela jurisdicional coletiva. Assim, como os direitos individuais homogêneos são considerados coletivos somente no plano processual, pois, materialmente, são divisíveis, o interesse social que justifica a sua tutela processual por intermédio de uma única ação é a origem comum, com o objetivo único de conveniência, para evitarem-se decisões contraditórias e o acúmulo de muitas demandas individuais de mesma natureza petitória (ASSAGRA DE ALMEIDA, Gregório. Direito processual coletivo brasileiro: um novo ramo do direito processual: princípios, regras interpretativas e a problemática da sua interpretação e aplicação, São Paulo, Saraiva, 2003, p. 482).
} 
A importância da tutela coletiva dos direitos individuais homogêneos e, especialmente, a razão de ser dessa modalidade de tutela, foi objeto de julgamento, já há mais de uma década, perante o Superior Tribunal de Justiça, nos autos do mandado de segurança 5187/DF, julgado em 24 de setembro de 1997 e relatado pelo Ministro Humberto Gomes de Barros. Nele, apontam-se diversas das razões, na linha das antes salientadas, para a tutela coletiva dos direitos, ressaltando-se que "as ações coletivas foram concebidas em homenagem ao princípio da economia processual. $\mathrm{O}$ abandono do velho individualismo que domina o direito processual é um imperativo do mundo moderno. Através dela, com apenas uma decisão, o Poder Judiciário resolve controvérsia que demandaria uma infinidade de sentenças individuais. Isto faz o Judiciário mais ágil. De outro lado, a substituição do indivíduo pela coletividade torna possível o acesso dos marginais econômicos à função jurisdicional. Em se permitindo, o Poder Judiciário aproxima-se da democracia". Esse julgado revela que a jurisprudência brasileira pode absorver o instituto, reconhecendo seus benefícios e livrando-se da ótica eminentemente individual, de forma a proporcionar a defesa efetiva dos direitos coletivos em sentido lato, aproveitando-se dos evidentes ganhos do tratamento coletivo dos direitos e proporcionando a própria realização da Justiça ${ }^{47}$.

Esse é o espírito que deve nortear o legislador e o aplicador do direito ao tratar dos direitos transindividuais. A ideia é a solução de conflitos de modo globalizado, com um dispêndio de tempo menor do que aquele que seria gasto se as demandas fossem tratadas individualmente, e, além disso, com uma maior eficácia, visto a maior força da decisão coletiva em relação a um agente causador do dano. Isso conduz, inclusive, à efetivação voluntária do direito material, de acordo com o pensamento de Gidi, que anota que, "exatamente porque se proporciona o acesso econômico e efetivo à justiça de

\footnotetext{
No mesmo sentido, ressaltando os aspectos benéficos da tutela coletiva dessa sorte de direitos não essencialmente coletivos, Eduardo Arruda Alvim anota que "a possibilidade de tutela coletiva dos interesses individuais homogêneos trouxe pelo menos duas grandes vantagens. Por primeiro, permitiu que uma parcela expressiva da população, economicamente alijada do acesso ao Judiciário, pudesse beneficiar-se das ações coletivas. Mas não apenas isso. Possibilitou, ainda, que questões que isoladamente consideradas não têm grande repercussão cheguem ao Judiciário, porque, tratadas em conjunto, apresentam relevância tal que justifica que possam ser perseguidas pelos entes legitimados a tanto, beneficiando, com isso, a um imenso número de pessoas, que, sozinhas, muito possivelmente não bateriam às portas do Judiciário para dirimir questões individuais de pequena importância, se individualmente consideradas" (ARRUDA ALVIM, Eduardo, "Coisa julgada e litispendência ....", Op. Cit., p. 175).

${ }^{47}$ V. ZAVASCKI, Teori Albino. Processo Coletivo ....., Op. Cit., p. 172.
} 
pretensões de pequeno valor, estimula-se a aplicação voluntária e autoritativa do direito material" $" 48$.

Contudo, não se pode pretender que toda espécie de direito individual que possa ter semelhança com a de pessoas na mesma situação jurídica seja tratada de modo coletivo, pois esse processo exige uma faceta positiva, qual seja, a de que exista predominância das questões comuns sobre as individuais, sob pena de se ter uma ação apenas pseudo-coletiva, em que as questões individuais sobressaem-se às comuns. Nessa hipótese, que é verificada na prática, o tratamento coletivo desses direitos individuais não tem razão de ser, em vista de ser necessária uma ampla análise das circunstâncias fáticas de cada um dos indivíduos interessados ${ }^{49}$.

Desse modo, o direito processual coletivo revela-se importante não só como forma de garantir a proteção de interesses, galgados a direitos, essenciais na sociedade contemporânea, de massa e globalizada, mas também como forma de o próprio Estado propiciar uma mais adequada tutela de direitos, tornando efetivos princípios constitucionais que, sem isso, poderiam ser meramente teóricos ${ }^{50}$.

Para o prosseguimento deste estudo, será realizado um breve histórico referente ao surgimento das demandas de natureza coletiva, primeiramente no sistema de common law, e, após, no ordenamento brasileiro, a fim de que se possa passar ao objeto

\footnotetext{
${ }^{48}$ GIDI, Antonio. A Class Action como ..... Op. Cit., p. 33. O autor coloca a efetivação do direito material, assim, ao lado do acesso à justiça e da economia processual, como um dos objetivos da tutela coletiva. Ressalta, ainda, que, no direito norte-americano, a função inibitória da tutela (deterrence) é muito forte, servindo o processo coletivo, desse modo, também para evitar a prática de atos danosos pelos infratores, cultura que é pouco difundida no Brasil, quiçá pela ainda baixa atuação dos corpos intermediários nesse campo.

${ }^{49}$ Sobre o processo coletivo e as ações pseudo-coletivas, v. MANCUSO, Rodolfo de Camargo. Jurisdição coletiva e ...., Op. Cit., p. 65.

${ }^{50}$ Consoante observa Assagra de Almeida, o direito processual coletivo "vem coroar, mesmo que já no início de um novo século, o movimento de defesa dos interesses primaciais da comunidade, que deveria ter se iniciado, como observou José Ortega y Gasset, no século XIX, e possibilitar, com a criação de regras e princípios específicos de interpretação, uma tutela jurisdicional mais efetiva e dinâmica, como já havia manifestado Édis Milaré, ao sustentar que, para uma sociedade de massa, há de existir igualmente um processo de massa" (ASSAGRA DE ALMEIDA, Gregório. Direito processual coletivo..., Op. Cit., p. 45).

Na mesma linha de raciocínio, Adamovich ressalta que a forma coletiva do processo é aquela em que a preocupação com as pessoas não de dá na dimensão intersubjetiva do litígio, mas num plano transcendente em que se cogita resolver não apenas um conflito, uma querela de vizinhos ou desavença entre marido e mulher; um plano que é o da preservação e efetividade dos direitos, mas também é o da concepção normativa do direito, mercê da projeção semelhante à das leis, que alcançam muitas decisões em processos da espécie (ADAMOVICH, Eduardo Henrique Raymundo von, "A Justiça Geométrica e o Anteprojeto ....", Op. Cit., p. 57).
} 
central deste trabalho, o da representatividade adequada e suas consequências nos diversos institutos do direito processual.

\subsection{Nascimento e desenvolvimento das class actions no sistema de common law}

Antes de se adentrar a análise dos ordenamentos de common law, é importante deixar assente que o desenvolvimento das class actions será estudado, especialmente, a partir do sistema norte-americano, o que se justifica.

Como anotou Mullenix, no relatório geral elaborado por força do XIII Congresso Mundial da Associação Internacional de Direito Processual, os Estados Unidos têm a mais velha e duradoura experiência com ações coletivas, na forma das class actions norte-americanas, em relação à qual se desenvolveu ampla jurisprudência, após quase setenta anos de experiência ${ }^{51}$. Assim, certamente, com eventuais anotações pontuais quanto aos sistemas dos outros países de common law, será tomado por base esse específico ordenamento, no desenvolvimento deste estudo, porque se acredita, em face da experiência e do seu uso como modelo pelos demais ordenamentos, ser o mais completo e o que propiciará a mais ampla análise comparativa.

Com base nisso, ressalta-se também que não se mostra possível, de forma abrangente, a análise do sistema norte-americano, pois se deve recordar que os Estados Unidos são uma República Federativa, em seu sentido puro, de modo que cada um de seus Estados pode desenvolver um sistema jurídico próprio, como a maioria de fato o faz, inclusive no que toca aos processos coletivos. De qualquer modo, existiu uma

\footnotetext{
${ }^{51}$ MULLENIX, Linda e outros. Os Processos Coletivos nos Países ....., Op. Cit., p. 254/256 e 272. A autora observa que "the American class action is a rule-based system for aggregating claims into a representative action. In both Australia and Canada, several (but not all) states and provinces have enacted class action legislation which is modeled on the American class action rule, but diverges from the American model in several crucial respects. In addition, the jurisprudence surrounding class action in Australian states and Canadian provinces has developed independent of American class action jurisprudence. Finally, collective actions in the United Kingdom, Scotland, and Wales are conceptually the most remote from the American class action model". Anota ainda a autora, que, diferentemente do que ocorre na União Europeia e nos países Ibero-americanos, não há nenhuma tendência, nos países de common law, como sói com eles acontecer, de unificação de suas leis quanto aos processos coletivos.

Ao estabelecer premissas para o estabelecimento do sistema norte-americano como paradigma, Salles anota que tal se dá por aquele país ser economicamente hegemônico, o que deve atrair atenção para seu sistema jurídico e por conveniência do estudo de mecanismos processuais que já se revelaram eficientes e eficazes (SALLES, Carlos Alberto de. "Ações coletivas: premissas para comparação com o sistema jurídico norteamericano", in SALLES, Carlos Alberto de, SILVA, S. T.., NUSDEO, Ana Maria de Oliveira. Processos coletivos e tutela ambiental. Santos: EDUL - Editora Universitária Leopoldiaum, 2006, p. 17/18).
} 
evolução nacional na proteção do instituto, que pode ser analisada, inclusive, para que se observe seu desenvolvimento.

Feita essa anotação, é de se salientar que a proteção dos direitos coletivos dá-se, nos ordenamentos de common law, por meio da class action, instrumento maior da ação representativa, em que os titulares do direito são representados em juízo por legitimados adequados para tanto, que defendem o direito da classe em nome próprio ${ }^{52}$.

O nascimento das class actions remonta às origens do direito inglês, no qual existiam a jurisdição do direito (law) e a jurisdição da equidade (equity) ${ }^{53}$. A primeira era mais formal, rígida e burocrática e tratava de questões pecuniárias e indenizatórias (damages). A segunda tratava dos provimentos de natureza declaratória e injuntiva (injunctions) e tinha natureza complementar, além de ser mais flexível que a jurisdição do direito.

Na law jurisdiction, não se permitia o litisconsórcio voluntário, em relação àqueles ligados por uma situação de fato comum, o que se permitia na equity, em vista da natureza antes explicitada. Todavia, um de seus requisitos era a intervenção de todos os interessados (necessary parties rule) para que o provimento jurisdicional pudesse ser concedido em caráter erga omnes. No entanto, no século XVIII, percebeu-se que não era possível a exigência da intervenção de todos os interessados, pois, com isso, em alguns

\footnotetext{
${ }^{52}$ Conforme definição de Mullenix, "the central characteristic of the American class action procedure is that it is representational litigation, not actual party litigation. Because the American class action rule is representational, from the outset American class action jurisprudence has been predominantly concerned with the constitutional due process protection of the interests of absent class members" (MULLENIX, Linda e outros Os Processos Coletivos nos Países ....., Op. Cit., p. 262/263).

${ }^{53}$ Tradicionalmente, é essa a origem das class actions apontada pelos estudiosos. No entanto, como ressalta Celso Cintra Mori, a origem pode ter sido muito anterior. Menciona que o professor Stephen Yeazell, da Universidade da Califórnia, contestou a versão clássica no livro From Medieval Group Litigation to the Modern Class Action (Yale University Press, 1950). Como anota o autor, referindo-se a esse estudo, "o conceito de grupo litigante surgiu por múltiplas formas, centenas de anos antes do Bill of Peace. Relata que constituía longa tradição na Inglaterra e em outros países da Europa o fato de grupos organizados ou indivíduos precariamente associados formularem pleitos em razão de lesões à comuna, pleitos esses que eram ouvidos e julgados. São citados os exemplos de mercadores manipulando o mercado, pregadores de igrejas diversas perturbando a paz religiosa, ou famílias poderosas intimidando jurados" (MORI, Celso Cintra. "A litispendência entre ações individuais e ações civis coletivas em defesa dos interesses individuais homogêneos", in Revista do Advogado, n. 84, AASP, dez/05, p. 28).

Contudo, parece-nos correta a distinção feita por Diogo Maia, que, apegando-se ao conceito de classe antes mencionado, ressalta que "a ideia de grupo existente àquela época era atribuída a uma coletividade de fora para dentro, como um status. Assim como na sociedade romana, não havia a invocação, pela classe, da sua condição de grupo organizado em um movimento de auto-identificação como tal, pois a própria imputação do status impedia que a consciência de classe se manifestasse". Essa consciência, de fato, só emergiu na era industrial (MAIA, Diogo Campos Medina. Ação Coletiva ...., Op. Cit., p. 10/11).
} 
casos em que esses eram muitos, impedia-se a concessão do provimento jurisdicional em favor de alguns, quando eventualmente apenas um não ingressasse no feito.

Em vista dessas dificuldades, foi editado o Bill of Peace, por meio do qual se possibilitavam exceções à regra do litisconsórcio, o que se dava com as ações representativas (representative actions), nas quais um representante do grupo agia, em juízo, para a defesa dos interesses dos demais. Contudo, esse tipo de ação não era irrestritamente permitido, pois só poderia ocorrer na hipótese de haver numerosidade dos interessados, o que tornava o litisconsórcio impraticável; de existir o interesse comum e de ser o representante adequado dos interesses dos demais ${ }^{54}$.

Por conta das class actions, não só um novo meio de tutela jurisdicional foi concebido, mas o sistema da equidade também impôs a criação de novos direitos materiais e de novos provimentos jurisdicionais (remedies), que passaram, com o tempo, a ser usados não só no sistema de equity, mas também em situações não adequadamente protegidas pela law, o que auxiliou no desenvolvimento do sistema.

Dessa forma, as representative actions tiveram grande avanço na equity e possibilitaram a criação, como se disse, de uma série de direitos somente conhecidos e tuteláveis nesse sistema, originando, assim, um verdadeiro conflito com o sistema da law. Tanto é que os Estados Unidos da América, por força do colonialismo inglês, adotaram a distinção entre equidade e direito em seu ordenamento. Todavia, diferentemente de sua metrópole, não se dividiram os Tribunais, pois ambos os sistemas eram aplicados pela mesma Corte. Desse modo prosseguiu o ordenamento norte-americano, mesmo após a independência, em 1776, e a criação do sistema judiciário federal, em 1789.

Após esse momento, o ordenamento estadunidense passou a ter desenvolvimento maior no sentido da eficácia das representative actions, a que se seguiram, após, as class actions. A primeira codificação desse tipo de ação ocorreu nos Estados Unidos, em 1842, por meio da Federal Equity Rule 48, que trazia termos bastante

\footnotetext{
${ }^{54}$ Desse modo, como ressalta Gidi, "historicamente, a criação das class actions deveu-se à necessidade e conveniência de 'contornar' a regra de litisconsórcio necessário de todos os interessados, para que fosse possível fazer justiça nas situações em que tal litisconsórcio não era possível”, de maneira que, de certo modo, o Bill of Peace foi o grande precursor das modernas class actions. (GIDI, Antonio. A Class Action como ...., Op. Cit., p. 42).
} 
genéricos ${ }^{55}$ e já anotava a impossibilidade de se prejudicarem os ausentes. Posteriormente, em 1912, foi promulgada a Federal Equity Rule $38^{56}$, também sem muita especificidade, pois tratava de um procedimento bem mais simples do que aquele hoje existente.

Em 1938, foram promulgadas as Federal Rules of Civil Procedure, que, em sua Regra 23, dispunham sobre as ações coletivas. Esse foi o primeiro instrumento, emanado não pelo Legislativo, mas pela Suprema Corte, que, lícita e efetivamente trouxe normas mais específicas sobre aquelas ações coletivas. Por meio dessas Rules, os sistemas da equity e da law foram unificados, de modo que passou a existir apenas um tipo de ação, as class actions, aptas à tutela também dos direitos reconhecidos pela law. Essa regulamentação também foi importante, haja vista que permitiu a existência de ações coletivas de caráter indenizatório (as class actions for damages), que se tornaram um dos instrumentos de maior aplicação nas ações coletivas.

Com a Rule 23, foram criados três tipos de ações coletivas, as true class actions, que tratavam dos direitos coletivos propriamente ditos, as hybrid class actions, que versavam sobre direitos de propriedade específicos, mas divisíveis, e as spurious class actions, que também tratavam de direitos divisíveis de grupos (several). Apenas as do primeiro tipo eram consideradas as verdadeira ações coletivas, como o próprio nome diz, em vista dos direitos envolvidos. Nelas, a coisa julgada se estendia erga omnes, tal qual hoje ocorre. Nas demais (as híbridas eram um meio termo entre ambas), não havia a extensão da coisa julgada para além do grupo. Nas palavras de Gidi" ${ }^{57}$, "as spurious class actions não eram consideradas uma verdadeira ação coletiva, mas simplesmente uma técnica que permitia o litisconsórcio facultativo (posterior) e a intervenção. Era meramente um permissive joinder device: um 'convite' a que os demais membros do grupo lesado se unissem a um mesmo processo".

\footnotetext{
${ }^{55}$ A Federal Equity Rule 48 dispunha: "Where the parties on either side are very numerous, and cannot, without manifest inconvenience and oppressive delays in the suit, be all brought before it, the Court in its discretion may dispense with making all them parties, and may proceed in the suit, having sufficient parties before it to represent all the adverse interest of the plaintiffs and defendants in suit properly before it. But, in such cases, the decree shall be without prejudice to the rights and claims of all absent parties". Extraído de GIDI, Antonio. A Class Action como ...., Op. Cit., p. 501.

${ }^{56}$ A Federal Equity Rule 38 dispunha: "When the question is one of common or general interest to many persons constituting a class so numerous as to make it impracticable to bring them all before the court, one ore more may sue or defend for the whole". Também extraído de GIDI, Antonio. A Class Action como ...., Op. Cit., p. 501.

${ }^{57}$ GIDI, Antonio. A Class Action como ...., Op. Cit., p. 52.
} 
No entanto, a distinção entre as ações era muito tênue e muito dificilmente compreendida tanto pela doutrina quanto pelos Tribunais. Por conta disso, inúmeras críticas surgiram à divisão trazida pela Rule 23 , o que contribuiu sobremaneira para que viesse a ser posteriormente reformada. Além disso, em virtude do regime da coisa julgada, muitos apontavam como inadequado e injusto ao réu o sistema trazido com as spurious class actions, o que também influenciou sua reforma.

Pelo que se verifica nos estudos do direito norte-americano, até a reforma da Rule 23, em 1966, a adequação dos fatos a uma das três sortes de direito era muito difícil, o que dificultava a efetiva utilização do instituto, por não existir verdadeira correspondência entre a classificação abstrata e o direito que se buscava tutelar ${ }^{58}$. Após a reforma, a aplicação do instituto foi crescente e ainda o é até hoje, de forma a se mostrar essencial o estudo de suas hipóteses de cabimento.

\subsubsection{Os requisitos e as hipóteses de cabimento das class actions norte-americanas}

A nova Rule 23, após a reforma de 1966, estabeleceu requisitos (a) ${ }^{59}$ e hipóteses de cabimento (b) ${ }^{60}$ das class actions, além de aspectos procedimentais. Procurar-

\footnotetext{
${ }^{58}$ Como aduz, nesse sentido, Paschoal, até os anos sessenta, nos Estados Unidos, não houve muitas ações coletivas porque sempre se tinha que enquadrar os direitos envolvidos numa das três classificações antes trazidas. Posteriormente, após 1966, com a reforma da Rule 23, a aplicação do instituto foi crescente, diante da alteração de seus requisitos, afastando-se as três categorias antes existentes (PASCHOAL, Maximiliam Fierro. A representatividade adequada ...., Op. Cit, p. 57/58).

Para Gidi, a regra foi completamente reescrita quando da reforma, pois "em lugar das antigas categorias de class actions baseadas em modelos abstratos e formalísticos de relações jurídicas, a nova redação previa um modelo bem mais compreensível, amplo, flexível e funcional, baseado em um critério mais pragmático, voltado principalmente para a existência de interesses comuns entre os membros do grupo" (GIDI, Antonio. A Class Action como ...., Op. Cit., p. 57).

59 “(a) Prerequisites to a Class Action. One or more members of a class may sue or be sued as representative parties on behalf of all only if

(1) the class is so numerous that joinder of all members is impracticable,

(2) there are questions of law or fact common to the class,

(3) the claims or defenses of the representative parties are typical of the claims or defenses of the class, and

(4) the representative parties will fairly and adequately protect the interests of the class".

60 “(b) Class Actions Maintainable. An action may be maintained as a class action if the prerequisites of subdivision (a) are satisfied, and in addition:

(1) the prosecution of separate actions by or against individual members of the class would create a risk of (A) inconsistent or varying adjudications with respect to individual members of the class which would establish incompatible standards of conduct for the party opposing the class, or (B) adjudications with respect to individual members of the class which would as a practical matter be dispositive of the interests of the other members not parties to the adjudications or substantially impair or impede their ability to protect their interests; or

(2) the party opposing the class has acted or refused to act on grounds generally applicable to the class, thereby making appropriate final injunctive relief or corresponding declaratory relief with respect to the class as a whole; or
} 
se-á, neste estudo, trazer um breve apanhado do que de mais relevante nela existe, relegando-se para os capítulos subsequentes o tratamento de temas específicos, como a representatividade adequada, a legitimidade e a coisa julgada.

De acordo com o texto da regra, uma ação só poderá ser tida como coletiva se preenchidos todos os requisitos especificados na Rule 23(a), quais sejam, numerosidade excessiva, que impede a formação de um litisconsórcio (1), existência de questões de fato ou de direito comuns (2), tipicidade dos pedidos em relação aos membros do grupo (3) e representatividade adequada em juízo (4). O ônus de demonstrar a presença desses requisitos, ou, ao menos, de trazer prova razoável quanto a eles, é do autor da demanda coletiva, em uma fase prévia, existente tão só para aferi-los, na denominada fase de certificação.

Os dois primeiros são questões extraprocessuais, que dizem respeito à situação litigiosa existente entre as partes e devem ser analisados de modo objetivo. São o mínimo necessário para que uma controvérsia, em tese, possa ser tratada de forma coletiva. Por outro lado, os outros dois tocam à situação endoprocessual e referem-se diretamente ao que se traz a juízo, de forma que, presentes os primeiros, mas havendo vícios nos segundos, esses podem ser corrigidos, substituindo-se, por exemplo, o pólo ativo da demanda, para que esse seja um representante adequado dos interesses do grupo.

O primeiro dos requisitos (a)(1), chamado pela doutrina, com apoio na lei, como o da numerosidade, como antes se referiu, não se prende propriamente a termos numéricos, pois, na realidade, consiste mais na impraticabilidade da realização do pedido em litisconsórcio. Esse requisito remonta às origens do instituto, uma vez que, tal qual já referido, o Bill of Peace teve como um de seus objetivos o de eliminar as dificuldades da exigência do litisconsórcio.

(3) the court finds that the questions of law or fact common to the members of the class predominate over any questions affecting only individual members, and that a class action is superior to other available methods for the fair and efficient adjudication of the controversy. The matters pertinent to the findings include: (A) the interest of members of the class in individually controlling the prosecution or defense of separate actions; (B) the extent and nature of any litigation concerning the controversy already commenced by or against members of the class; (C) the desirability or undesirability of concentrating the litigation of the claims in the particular forum; (D) the difficulties likely to be encountered in the management of a class action". 
De acordo com o que anota Gidi ${ }^{61}$ quanto a esse requisito, não se trata de impossibilidade absoluta de formação de um litisconsórcio, mas de ele trazer dificuldades processuais, que prejudiquem o desenvolvimento do processo, situação que acarretaria danos à própria proteção dos direitos, que se veria retardada, quando não definitivamente obstada.

A situação prevista na Rule, de certo modo, amolda-se à previsão constante do Código de Processo Civil Brasileiro, que, em 1994, teve inserido parágrafo único em seu artigo 46, estabelecendo que "o juiz poderá limitar o litisconsórcio facultativo quanto ao número de litigantes, quando este comprometer a rápida solução do litígio ou dificultar a defesa". Sem dúvida, é essa mesma dificuldade a que se refere o requisito (a)(1) da Rule 23, mas, na regra americana, a solução é ter um interessado agindo em nome dos demais, ao invés de se desmembrarem ações individuais várias.

Assim, a análise do contido no item (a)(1) não deve ser feita sob o aspecto meramente numérico, como parece acontecer, de acordo com o enunciado contido na lei, mas, sim, pela efetiva impraticabilidade do litisconsórcio, o que pode se dar com processos que versem sobre direitos de pouco mais de uma dezena de interessados ou de centenas ou milhares deles.

O requisito (a)(2) determina a existência de questões de fato ou de direito comuns (commonality). Essa exigência é, na realidade, a própria essência dos processos coletivos, pois, se cada indivíduo tivesse seu próprio direito diferente ou conflitante com o dos demais, como se uma pessoa só não fossem, não seria possível a tutela coletiva. Esse requisito é, assim, o que define a própria existência de um direito de grupo, sendo aquilo que a lei brasileira denomina, em sua classificação dos direitos coletivos antes vista, "circunstâncias de fato", "relação jurídica base" ou "origem comum", conforme o tipo de direito envolvido.

\footnotetext{
${ }^{61}$ Como bem define Gidi, presente estará o requisito "quando há dificuldade ou inconveniência de se administrar um processo com a presença de todos os interessados, em que se deve manejar um numero muito grande de papéis e assinaturas (petições, requerimentos, documentos, provas etc.), resolver problemas de sucessão processual etc.". Ou ainda "se for inviável que todos os membros do grupo se aliem para propor um litígio em litisconsórcio". O autor menciona também a questão da reduzida pretensão individual dos membros do grupo, em uma perspectiva econômica, além do receio da exposição ao público, citando exemplos de direitos atinentes a prostitutas e homossexuais, como formas de preenchimento desse requisito (GIDI, Antonio. A Class Action como ...., Op. Cit., p. 72/73).
} 
Não existe necessidade de serem todas as questões absolutamente iguais entre todos os interessados, sendo imperativo apenas existir um núcleo de controvérsia comum entre os diversos integrantes do grupo. Todavia, uma mera potencialidade de tratamento coletivo não basta para a certificação da ação como coletiva, havendo necessidade de efetivamente existir uma questão coletiva, o que pode ser externado pela definição da causa de pedir e do pedido, tal qual antes explicitado quando da definição brasileira dos direitos passíveis de tutela. Aqui, a situação não se revela muito diferente, pois também será crucial, para a identificação do direito coletivo e para o desenvolvimento do processo coletivo, que a causa de pedir e o pedido deixem claras as questões comuns, que remetam aquele interesse à categoria de direito coletivo.

Interessante anotar que o juiz norte-americano pode, na fase de certificação da demanda coletiva, se não preenchido esse requisito, redefinir o grupo, dividi-lo, limitar a controvérsia, tudo antes de negar a demanda coletiva, pois a ideia é sempre, como antes já se colocou, a de tentar salvá-la, ao menos em relação à parte do que havia sido submetido a juízo ${ }^{62}$.

O terceiro dos requisitos, o da tipicidade, especificado no item (a)(3), significa que o pedido ou a defesa do representante do grupo em juízo deve ser típico dos outros membros do grupo, ou seja, é a questão comum anteriormente vista sendo trazida para dentro do processo. Mediante a observação desse requisito, a solução da lide individual daquele representante propiciará a solução da lide do grupo.

No entanto, de igual modo ao que antes se disse, as peculiaridades individuais de cada qual, desde que não interfiram na substância do direito trazido ao Judiciário, não impõem o afastamento do requisito ${ }^{63}$. Ademais, também tal qual já se

${ }^{62}$ Cf. GIDI, Antonio. A Class Action como ...., Op. Cit., p. 88/89.

Essa mesma possibilidade não existe no direito brasileiro vigente, pois aplica-se o disposto no Código de Processo Civil. No entanto, no direito projetado, é conferida ao juiz essa possibilidade, buscando-se, justamente, aumentar a eficácia da proteção dessa sorte de direitos. Nesse sentido, dispõe o artigo $9^{\circ}$ do Projeto que "não haverá extinção do processo coletivo, por ausência das condições da ação ou pressupostos processuais, sem que seja dada oportunidade de correção do vício em qualquer tempo ou grau de jurisdição ordinária ou extraordinária, inclusive com a substituição do autor coletivo, quando serão intimados pessoalmente o Ministério Público, a Defensoria Pública e, sempre que possível, outros legitimados para a adoção das providências cabíveis, em prazo razoável, a ser fixado pelo juiz".

${ }^{63}$ No Brasil, como já se a anotou neste capítulo, as questões individuais são analisadas em fase posterior, de liquidação da sentença coletiva, na qual cada titular do direito irá trazer a juízo seus danos e provar o nexo de causalidade com a conduta ofensiva, já reconhecida na demanda coletiva. 
ressaltou, o não preenchimento do requisito na propositura da demanda não acarreta, de plano, a extinção do feito, cabendo ao juiz readequar o grupo ou buscar um representante que atenda às especificações da Rule $^{64}$.

Por fim, o último dos requisitos, aquele especificado no item (a)(4) é o da representatividade adequada, que, por ser objeto central deste estudo, será estudado em capítulo próprio.

De qualquer modo, verifica-se que a sobreposição entre os requisitos é bastante corriqueiro, pois, muitas vezes, não se poderá identificar um representante, sem que exista uma questão de fato comum. Desta feita, os dois primeiros requisitos, somados à representatividade adequada, que, como se verá adiante, é matéria interna ao processo, são as verdadeiras condições para a certificação de uma demanda coletiva, uma vez que os demais podem ser corrigidos, aditados e superados, tudo para que se tenha uma apropriada defesa dos interesses do grupo.

Assim, após o preenchimento dos requisitos especificados no item (a) da Rule 23, deve a demanda coletiva enquadrar-se numa das hipóteses de cabimento trazidas em seu item (b), quais sejam risco de conflito de decisões (1), conduta uniforme do réu (2) e predominância das questões comuns (3). Em linhas gerais, os tipos de class actions especificados pela norma correspondem àqueles originalmente constantes da Rule 23 antes da reforma de 1966. Todavia, a classificação facilitou o trabalho de aplicação da lei, pois simplificou e limitou os conceitos.

A regra contida no (b)(1) busca evitar a existência de decisões conflitantes, se as ações forem propostas de modo individual ou segmentado. A subdivisão da norma especifica tanto decisões inconsistentes ou conflitantes, o que se analisa à luz dos prejuízos para a parte contrária, quanto o perigo de causar danos a outros membros do grupo, alheios ao processo individual, em detrimento dos demais. Neste ponto, observa-se que as ações cabíveis com base nesse requisito são instrumentos importantes para a

\footnotetext{
${ }^{64}$ De acordo com Gidi, “o requisito da tipicidade serve, então, para proteger os interesses dos membros ausentes, na medida em que visa a promover a sua adequada representação em juízo. Nesse ponto, há verdadeira sobreposição entre as finalidades dos requisitos da tipicidade e da representação adequada. $\mathrm{Na}$ cultura jurídica americana, um representante atípico é um representante inadequado e um representante inadequado é um não-representante" (GIDI, Antonio. A Class Action como ...., Op. Cit., p. 95).
} 
pacificação social, evitando que emerjam conflitos individuais desnecessários e com outras soluções, que podem afastar a necessária igualdade entre os indivíduos na mesma situação fática.

O especificado no item (b)(2) prevê hipótese de cabimento de class actions para sentenças declaratórias e mandamentais (declaratory e injunctive class actions), pois visa a obter um provimento nesse sentido em face da parte que agiu sem uniformidade em relação a diversos membros de um grupo. Essa modalidade de ação não tem, pois, cabimento nas pretensões de ressarcimento de danos, por não se enquadrarem em seu enunciado. Exemplo clássico do cabimento de uma class action sob essa alínea são os casos de discriminação e de tutela dos direitos civis, típicas ações que se enquadrariam como direitos difusos ou coletivos no ordenamento brasileiro.

Essas duas modalidades de class actions buscam tutelar, em linhas gerais e em termos de comparação com o ordenamento brasileiro, os direitos difusos (as previstas em (b)(1)) e coletivos (aquelas especificadas em (b)(2)), como se verifica de seus requisitos. Esse tipo de ação é denominado mandatory class action, pois seus comandos, em regra, não são de natureza condenatória, mas injuntiva, consistentes em obrigações de fazer ou não fazer. Essas suas modalidades podem ser analisadas em conjunto, pois, como adiante se verá, diversos institutos são igualmente a elas aplicados, como é o caso da coisa julgada, que será erga omnes, sem qualquer exceção, consoante se estudará nos capítulos subsequentes. É de se observar, como adiante se verá, que também são homogêneas as disposições para tutela desses dois tipos de direito no ordenamento brasileiro.

Além dessas duas hipóteses de cabimento, há o disposto em (b)(3), que, na realidade, visa a tutelar o que aqui chamamos direitos individuais homogêneos. Estabelece a norma a necessidade de existir predominância de questões comuns, fazendose necessário que o autor coletivo demonstre que tais questões comuns predominam sobre as individuais, o que é denominado predominance test, e que a demanda coletiva será um meio superior, em termos de justiça e eficiência, de resolver a disputa (superiority test). Ou seja, além das questões comuns é necessário trazerem-se a juízo as razões que conduzem à necessidade ou à preferência pela tutela coletiva desses direitos. 
Essa é a hipótese mais comum de class action, em que se inserem as demandas voltadas à indenização de prejuízos coletivamente sofridos (class actions for damages not mandatory), inclusive aqueles de caráter individual, mas que merecem ser tratados de modo coletivo, pelas razões já anteriormente estudadas. Nesse caso, como adiante se verificará, em especial quando do estudo da coisa julgada, essa ação não é obrigatória, de modo que não atingirá todos os indivíduos integrantes do grupo de lesados, já que, no ordenamento norte-americano, esses podem requerer a expressa exclusão do grupo, por meio do instituto do opt out.

Hoje, pode-se afirmar que o sistema de defesa dos direitos coletivos é preponderante na atividade jurídica dos Estados Unidos, dada a relevância que os famosos mass tort cases e as class actions for damages têm, não só internamente, mas também como fonte de inspiração de ordenamentos alienígenas, como o brasileiro. Todavia, existe preocupação da doutrina quanto ao uso inadequado dessas ações, mediante fraude ou colusões entre as partes, situação que, por sua força política e econômica, pode gerar danos de enorme monta ${ }^{65}$.

De qualquer forma, é certo que se trata de um procedimento bastante útil e eficaz para a tutela dos direitos coletivos, assim entendidos em sentido amplo, de maneira que não se deve pensar em sua extinção, mas apenas em eventual aprimoramento; isso porque ele se mostrou apropriado, apesar de, naturalmente, haver desvios de finalidade em sua utilização, o que é normal em qualquer instituto jurídico, mas não indica de forma peremptória que a sua previsão é equivocada.

\footnotetext{
${ }^{65}$ Klonoff e Bilich ressaltam a importância do instituto naquele ordenamento, inclusive como forma de atuação política da sociedade, afirmando que "class actions (and other party-agregation devices) are powerful and persuasive instruments of social change". No entanto, salientam a preocupação ainda existente, diante da magnitude que podem ter essas ações, quanto à eficiência do procedimento. Obviamente, o que se busca por meio da propositura dessa sorte de ações é cumprir objetivos sociais, mas seus opositores têm justo receio de que elas sirvam como instrumento egoístico, utilizado em benefício exclusivo daqueles que se colocam como representantes de uma classe, questões que serão posteriormente abordadas neste estudo (KLONOFF, Robert H., BILICH, Edward K. M., Class actions and other multi-party litigation, St Paul, Minn., West Group, 2000, p. 01/02).

Gidi assinala também sua preocupação, salientando que esse tipo de ação é, hoje, um instrumento extremamente poderoso contra o poder institucionalizado, seja político, econômico ou social. O autor anota que há um grande movimento nas esferas de poder para diminuir sua força, mas a situação política é de completo impasse, especialmente porque há os que criticam os abusos cometidos por meio delas, como antes explicitado, e aqueles que criticam, ao revés, os abusos cometidos pelos detentores do poder econômico, mas isso, como ressalta ele, "é um reflexo da situação política dos Estados Unidos, polarizada e dividida, não permitindo nenhuma proposta mais ambiciosa ou polêmica" (GIDI, Antonio. A Class Action como ...., Op. Cit., p. 65/66).
} 
Após uma breve anotação da evolução histórica do instituto no Brasil, a seguir realizado, serão abordados temas específicos das demandas coletivas, em que se realizará um contraponto entre aquilo que existe no Brasil e comumente nos países de civil law e o que se prevê nos ordenamentos de common law, especialmente no norteamericano, pelas razões anteriormente já apontadas.

\subsection{Evolução da proteção aos direitos coletivos no Brasil}

Os direitos coletivos passaram a ser protegidos no Brasil em período um tanto posterior ao desenvolvimento das ações coletivas nos ordenamentos de common law. Todavia, o Brasil, suas leis, sua doutrina e seus julgados, não se mostram irrelevantes em matéria de direitos coletivos, pois foi o primeiro país ibero-americano a iniciar o pensamento coletivo e a desenvolver mecanismo de defesa desses direitos. O estudo mais aprofundado dos direitos coletivos no Brasil teve início na década de 70, com debates acerca de pensamentos da escola inglesa e americana e também da italiana ${ }^{66}$.

De início, cumpre salientar a importância da Lei da Ação Popular (Lei n. 4.717/65) que previu a defesa de certos tipos de direitos coletivos por seu legitimado único, o cidadão comum. Essa lei sofreu alteração significativa com a Constituição Federal de 1988, que ampliou seu objeto, buscando dar-lhe uma maior efetividade que então não se verificava. Contudo, sua aplicação não é predominante, talvez pela falta de cultura do cidadão brasileiro para buscar soluções aos problemas comuns, pelo que são mais relevantes as disposições das Leis n. 7.347/85 (Lei da Ação Civil Pública) e n. 8.078/90 (Código de Defesa do Consumidor).

Interessante ressaltar que, em vista do primeiro congresso realizado no Brasil em que se discutiram os direitos coletivos, em 1982, foi elaborado um Anteprojeto de lei para tutela dessa sorte de direitos, do qual participaram Ada Pellegrini Grinover, Cândido Rangel Dinamarco, Kazuo Watanabe e Waldemar Mariz de Oliveira Júnior. No entanto, esse Anteprojeto veio a ser substituído por outro de autoria do Ministério Público.

\footnotetext{
${ }^{66}$ Angelo De Santis deixou assente a primazia dos estudos brasileiros, em relação àqueles italianos referentes aos direitos e processos coletivos, anotando que, na Itália, a discussão a respeito intensificou-se apenas no fim dos anos 80, momento em que se impôs uma reestruturação da justiça civil, em razão das "mutate esigenze di tutela derivanti da una economia di massa" (DE SANTIS, Angelo Danilo. "I disegni di legge italiani sulla tutela degli interessi collettivi e il class action fair act of 2005", in Rivista Trimestrale di Diritto e Procedura Civile, Milão, v. 60, n. 2, jun/2006, p. 602/603).
} 
Isso decorreu do lobby dessa entidade, que pretendia ser a única legitimada à propositura de ações em defesa dos direitos coletivos, amplamente considerados. Tanto é assim que a lei decorrente desse projeto foi a denominada Lei da Ação Civil Pública, assim chamada justamente para contrapor-se à ação penal, da qual já era quase que exclusivamente titular o Ministério Público. Certamente por essa razão é que se incutiu na sociedade a ideia de que é esse órgão responsável pela tutela dos direitos coletivos, não se incentivando a criação de organismos sociais intermediários para tanto ${ }^{67}$.

A essa lei, que criou mecanismos de defesa para os danos causados ao meio ambiente, ao consumidor, a bens e direitos de valor artístico, estético, histórico, turístico e paisagístico e aos direitos difusos em geral, seguiram-se inúmeras outras específicas, tutelando interesses das pessoas portadoras de necessidades especiais (Lei $\mathrm{n}$. 7.853/89), das crianças e adolescentes (Lei n. 8.069/90), da probidade administrativa (Lei n. 8.429/92), da ordem econômica (Lei n. 8.884/94) e das pessoas idosas (Lei n. 10.741/03).

Ademais, consoante se ressaltou no início deste capítulo, a própria Constituição Federal trouxe dispositivos importantes para garantir a tutela dos direitos coletivos, estabelecendo expressamente essa possibilidade, e elencando a ação popular e a ação civil pública como meios de o fazer.

De qualquer modo, são a Lei da Ação Civil Pública e o Código de Defesa do Consumidor os dois instrumentos legais mais importantes na evolução da proteção dos direitos coletivos no Brasil, visto eles terem consolidado tanto a parte material quanto aquela processual atinente à proteção dos direitos. Aquele Código foi, outrossim, de importância fundamental, pois, como se viu, inspirado nas ações de classe norte-americanas, previu a ação ressarcitória por danos pessoalmente sofridos (class actions for damages), o que, até então, não tinha previsão legal no Brasil.

\footnotetext{
${ }^{67}$ V. PASCHOAL, Maximiliam Fierro. A representatividade adequada ...., Op. Cit, p. 76/77.

Os prós e os contras da atuação do Ministério Público como autor legitimado da ação coletiva serão tratados no capítulo 4, mas se adianta, como já se pontuou anteriormente, que o ideal seria que a sociedade se organizasse para a defesa de seus próprios interesses, evitando a dependência a um agente estatal para tanto. Isso, sem dúvida, traria mais independência e efetividade para a defesa dos interesses coletivos.
} 
Após a edição do Código de Defesa do Consumidor, a utilização das ações coletivas cresceu muito no ordenamento brasileiro ${ }^{68}$. No entanto, ainda existe, em certos aspectos e por conta da arraigada cultura individualista, dificuldade de se lhe dar com a matéria. Os magistrados e os Tribunais, por não serem especializados, tentam, muitas vezes, solucionar as questões coletivas como se individuais fossem, dispensando recursos dos quais poderiam se valer nos processos coletivos. Em vista disso, mostra-se relevante o estudo da tutela jurisdicional coletiva, tentando-se, com isso, trazer elementos úteis para a solução dos litígios.

Não se pretende neste trabalho, para não fugir ao seu objeto central, realizar uma comparação ampla entre a forma de tutela dos direitos no ordenamento brasileiro e no norte-americano. Buscar-se-á, outrossim, ao tratar-se dos temas centrais deste estudo, realizar um paralelo, apontando o que eventualmente ainda se poderia absorver do sistema de common law, bem como dos institutos do direito processual civil brasileiro, de modo a tornar mais efetiva a tutela coletiva.

Assim, após o introito desse capítulo, em que se analisaram os direitos coletivos tuteláveis, a forma de sua defesa em juízo e, em linhas gerais, a evolução das legislações de common law e das brasileiras na tutela desses direitos, objetiva-se, nos capítulos subsequentes, deter-se sobre a representatividade adequada, objeto central deste estudo, e sobre as consequências já advindas ou que podem advir da sua aplicação nos processos de natureza coletiva, em especial no que toca à legitimação para agir e à coisa julgada, institutos de extrema relevância na ótica coletiva, exatamente porque diferenciais do processo civil comum e aptos a contribuírem para a efetividade da defesa dos direitos coletivos, amplamente considerados.

\footnotetext{
${ }^{68}$ Como ressalta Teori Zavascki, "formado todo esse cabedal normativo, não há como deixar de reconhecer, em nosso sistema processual, a existência de um subsistema específico, rico e sofisticado, aparelhado para atender aos conflitos coletivos, características da sociedade moderna" (ZAVASCKI, Teori Albino. Processo Coletivo ....., Op. Cit., p. 36).
} 


\section{REPRESENTATIVIDADE ADEQUADA}

Para o prosseguimento deste trabalho, após se ter especificado a sorte de direitos englobada no conceito de direitos coletivos e se ter realizado um breve panorama dos processos coletivos, especialmente quanto à razão de sua existência e aos seus objetivos, que serão priorizados no enfoque central deste estudo, a pretensão é adentrar o objeto principal, a representatividade adequada.

O objetivo dessa parte do trabalho não é ainda realizar um estudo crítico do instituto, mas, sim, trazer-se elementos de sua definição e suas características mais relevantes, para que a representatividade adequada possa ser emoldurada e, depois, situada no plano processual. Isso se mostra relevante para o desenvolvimento das duas partes seguintes do estudo, de cunho crítico e propositivo, nas quais se fará um cotejamento desse instituto, verdadeiro princípio dos processos coletivos, em face da legitimidade e da coisa julgada, duas das mais importantes facetas do processo coletivo, na distinção dele em relação ao processo tradicional.

\subsection{Representatividade adequada}

O processo é, a princípio, apenas um caminho previsto pela lei para a tutela dos direitos materiais. No entanto, ele pode, e cada vez mais se vê essa sua faceta, garantir a proteção desses direitos ou atuar favoravelmente para que essa ocorra. Nos processos coletivos, como foi visto no capítulo anterior, isso se dá ainda com maior rigor, pois eles são um efetivo instrumento de acesso à justiça e de economia jurisdicional, e possibilitam a resolução de inúmeros problemas de modo conjunto. A representatividade adequada é um de seus institutos mais importantes para que esses objetivos sejam atingidos, pois é capaz de agregar segurança a uma relação processual que não tem essa garantia tão facilmente vislumbrada.

O instituto é estudado pela doutrina, em sua quase totalidade, ao tratar da legitimação para as ações coletivas. Não há dúvidas de que entre eles existe uma relação intrínseca, como se verá na próxima etapa deste trabalho, porque a representatividade adequada integra o conceito de legitimidade. No entanto, sua análise não é indispensável 
para o estudo do instituto ${ }^{69}$, pelo que, neste trabalho, se preferiu trazer um capítulo próprio destinado a seu esboço, separado daquele referente à legitimidade, para que se tenha oportunidade de delimitá-lo adequadamente, de maneira que seu conceito e suas características possam servir de base para a análise de sua aplicação não só em relação à legitimidade, mas a outros institutos dos processos coletivos. Essa é a verdadeira razão para que este trabalho tenha como tema central a representatividade adequada e, assim, desenvolva-se no sentido de delimitar esse instituto, o que não é costumeiramente realizado pela doutrina, que dele trata apenas como mais um possível tópico da aferição da legitimidade.

A definição de representatividade adequada não é simples, pois o instituto é dotado de carga subjetiva, o que se verifica a partir de seu próprio nome, haja vista que o conceito de "adequação" não é objetivo e pode gerar uma série de definições e interpretações diferentes ${ }^{70}$. Do subjetivismo não só sua nomenclatura, mas o próprio instituto, que a reflete, também não está livre, pois sua ocorrência, em alguns casos, como se verá, dependerá de sua afirmação pelo magistrado, mediante a prova de sua existência pela parte interessada. Além disso, quando atribuída ao juiz essa afirmação, não se pode olvidar que ele é um ser humano, dotado de opiniões e de critérios de convencimento próprios. Como em qualquer outra questão subjetiva submetida ao Judiciário, não existe necessariamente certeza e apenas uma solução, dependendo de interpretação e podendo, pois, não acontecer o mesmo resultado em situações rigorosamente idênticas.

Importante ressaltar que a definição do instituto passa ao largo do conceito clássico de representação do direito processual, pois o representante adequado não é propriamente um representante, em seu sentido técnico-jurídico, mas um porta-voz ${ }^{71}$

${ }^{69}$ Como observou Susana Henriques da Costa, a representatividade adequada não se resume à legitimidade,
pois aquela é mais ampla, já que "exige o reconhecimento pelo juiz de outros elementos no caso concreto de
forma a garantir a satisfatória defesa da classe por seu membro" (COSTA, Susana Henriques da. "O Controle
Judicial da representatividade adequada: uma análise dos sistemas norte-americano e brasileiro", in SALLES,
Carlos Alberto de (coord.). As grandes transformações do processo civil brasileiro: homenagem ao
Professor Kazuo Watanabe. São Paulo: Quartier Latin, 2009, p. 959).
70 O Novo Dicionário Aurélio da Língua Portuguesa ( $2^{\mathrm{a}}$ ed., revista e ampliada, $40^{\text {a }}$ reimp., Rio de Janeiro,
Ed. Nova Fronteira, p. 44) define adequação como "1. Ato de adequar(-se). 2. Ajustamento, adaptação. 3 .
Correspondência exata, conformidade, identidade. 4 . Filos. Conformidade ou correspondência exata entre os
termos de uma relação". Assim, observa-se que, realmente, o instituto é subjetivo, pois nenhuma de suas
definições apresenta carga de objetividade, dependendo, pois, de uma vertente interpretativa.
71 Ou "intérprete", de acordo com interessante terminologia adotada por Barbosa Moreira, em estudo ainda
anterior à Constituição Federal e ao Código de Defesa do Consumidor, ao mencionar que as associações
poderiam agir não só como representantes de seus respectivos membros, mas "como intérprete, em nome 
daquele grupo ou daquela classe de indivíduos que tem um direito violado e necessita da atuação ativa de alguém para vê-lo reparado ${ }^{72}$. De acordo com Gidi, como não existe a expressa delegação de poderes por parte dos membros do grupo, o papel do representante se assemelharia mais ao do gestor de negócios do direito brasileiro. Todavia, ressalta que a distinção é meramente acadêmica e, como existe um regramento peculiar no direito norteamericano, convém manter a expressão, naquele ordenamento já consagrada ${ }^{73}$, com o que deve se concordar, pois o instituto já tem, naquele ordenamento, sua carga de "personalidade".

Na busca de uma definição para o instituto, é possível deparar com muitas delas, cada qual atribuindo uma natureza jurídica diversa para a representatividade adequada. No cuidadoso levantamento feito por Paschoal ${ }^{74}$, em diversas bases doutrinárias em que foi realizada uma análise breve do instituto, localizou-se sua definição como critério, requisito, aptidão, aspecto, qualidade, pressuposto e condição.

Não nos parece que o conceito se prenda a um pressuposto processual ou a uma condição da ação, pois essas definições referem-se à verificação da legitimidade endoprocessual e o representante adequado assim o é antes mesmo da existência do processo; ou seja, o conceito é material, inerente à própria figura do representante, como aqui se insiste em afirmar. Não há dúvidas de que possa esse instituto, ao ser analisado dentro do processo, constituir uma das condições da ação ${ }^{75}$, já que, como antes se disse, ele

próprio, das pretensões de cada um deles" (BARBOSA MOREIRA. "Tutela constitucional ....", Op. Cit., p. 203).

${ }^{72}$ Cf. GIDI, Antonio. A representatividade adequada nas ações coletivas brasileiras. Revista de Processo, São Paulo, n. 108, out-dez/2002, p. 61-70.

No processo civil clássico, a representação ocorre mediante a atuação de alguém (em juízo ou fora dele) em nome de outra pessoa, física ou jurídica. Na definição de Capitant, é "el hecho de cumplir um acto jurídico em nombre o por cuenta de outra persona, em mérito a um poder legal o convencional y estableciendo para la persona representada um derecho u obligación" (CAPITANT, Henri. Vocabulario Jurídico. Buenos Aires: Depalma, 1979, p. 483).

Assim, do que se depreende da definição, para que se tenha a representação, é necessário que exista autorização da pessoa representada para tanto ou, em algumas hipóteses, autorização legal para sua atuação, como é o caso do inventariante como representante do espólio ou do tutor como representante do tutelado. Isso fica bastante claro na análise do Código de Processo Civil Português, que, em seu artigo 25, estabelece que, "se a parte estiver devidamente representada, mas faltar alguma autorização ou deliberação exigida pela lei, designar-se-á o prazo dentro do qual o representante deverá obter a respectiva autorização ou deliberação", que, se não atendida, acarretará a extinção da ação (na hipótese do autor) ou a revelia (no caso do réu).

${ }^{73}$ GIDI, Antonio. A Class Action como ...., Op. Cit., p. 243.

${ }^{74}$ V. PASCHOAL, Maximiliam Fierro. A representatividade adequada ...., p. 106/109.

${ }^{75}$ Cf. Cássio Scarpinella, a representatividade adequada é questão prejudicial para processamento de uma demanda, é condição de prejudicialidade (SCARPINELLA BUENO, Cassio. "As class actions norte- 
integra o conceito de legitimidade; no entanto, o que se busca aqui é uma definição para ele próprio, desatrelado de sua atuação processual.

De igual modo, não pode ser considerado um simples critério ou aspecto da pessoa, pois também vai além disso; deve sim ser analisado em face da relação jurídica material e não apenas intrinsecamente em relação à pessoa que como tal se apresenta.

Assim, a definição que parece mais acertada é aquela segundo a qual a representatividade adequada é uma qualidade apresentada pelo representante que atuará em nome da sociedade ou do grupo na defesa de interesses de ordem coletiva, qualidade essa identificada como a possibilidade da defesa eficiente e tenaz dos interesses envolvidos, seja no âmbito social, administrativo ou judicial ${ }^{76}$.

Neste ponto, revela-se com absoluta clareza a importância do estudo da representatividade adequada isoladamente, fora do contexto da legitimidade. Como se viu, uma pessoa é representante adequado de um grupo ou de uma classe independentemente da existência de um processo judicial, pois isso decorre da relação jurídica de direito material. Assim, os institutos de defesa dos consumidores são já, antes da existência de uma demanda, desde que sérios e atuantes, adequados representantes dos consumidores, assim como organismos não governamentais voltados à defesa do meio ambiente são, da mesma forma, adequados representantes daqueles que buscam sua incolumidade, independentemente de agirem em juízo. Assim sendo, a importância do estudo processual da representatividade adequada é, tão só, garantir que esses adequados representantes sejam os porta-vozes dos cidadãos, grupos e classes titulares de um direito judicialmente controvertido; isso não implica, entretanto, que o conceito de representante adequado deva ser ligado ao processo.

americanas e as ações coletivas brasileiras: pontos para uma reflexão conjunta”, in Revista de Processo, ano 21, n. 82, abr.-jun./1996, p. 102).

${ }^{76}$ A definição de Mirra é bastante explicativa. Segundo o autor, representatividade adequada é a "especial qualidade que [tais] titulares do direito de agir devem apresentar, consistente na aptidão para a defesa escrupulosa e eficiente, na esfera judicial, dos interesses da sociedade, em perfeita sintonia com as expectativas da coletividade na matéria, mesmo diante de litígios complexos e difíceis, muitas vezes contra os detentores do poder econômico (grandes grupos econômicos) e do poder político (dos próprios governos)" (MIRRA, Álvaro Luiz Valery, "Associações civis e a defesa .....", Op. Cit., p. 117). Importante anotar que a definição trazida por Mirra ainda faz referência à defesa dos direitos do grupo na esfera judicial, quando é certo, pelo que foi antes exposto, que, a nosso ver, não seria necessário circunscrever ao Judiciário a atuação do representante, pois ele possui essa "especial qualidade" independentemente da atuação nessa esfera. 
Quanto a esse aspecto, interessante anotar a afirmação de Fiss no sentido de que os grupos - e consequentemente seus representantes - existem independentemente da ação judicial, não sendo meras construções legais. Anota que o "grupo existe, tem uma identidade, pode ser prejudicado, mesmo que todos os indivíduos ainda não o estejam sendo e que cada membro individualmente considerado não esteja ameaçado pela organização". Assim, existindo o grupo, existirá também seu representante adequado, independentemente da judicialização de qualquer conflito. Esse representante, ainda na lição de Fiss, não precisa ser membro do grupo, pois isso poderia representar um sofrimento maior na defesa dos interesses. Muitas vezes, um terceiro consegue ter uma visão mais completa e não emocionalmente envolvida com o interesse ${ }^{77}$.

De qualquer forma, quando levado o direito ao Judiciário, será o representante adequado, num plano processual, e por força dessa sua qualidade, o próprio autor ou réu do processo coletivo. Todavia, ele não age em seu próprio nome, ou, ao menos, não só em seu próprio nome, mas em nome dos indivíduos titulares do direito que se objetiva seja tutelado, atuando, como se disse, como um porta-voz do grupo. A representatividade adequada é, assim, a qualidade desse representante, independente do processo judicial, mas existente sempre que o representante atende aos requisitos especificados para tanto.

Obviamente, antes de uma perquirição administrativa ou judicial dos direitos passíveis de tutela, a adequação do representante permanece velada, pois seus atos não terão, a princípio, efeito vinculante aos "representados". Todavia, a partir do momento em que o representante busca, nas esferas administrativa ou judicial, impedir a violação dos direitos, reparar uma afronta já ocorrente ou defender o grupo em face de eventuais direitos antagônicos de outras pessoas ou grupos, sua atuação deverá ser fiscalizada, para evitar que seus atos prejudiquem os diretamente interessados.

\footnotetext{
${ }^{77}$ V. FISS, Owen. Um novo Processo ...., Op. Cit., p. 51/52.

Pode-se extrair a mesma conclusão de José Marcelo Vigliar, que salienta que representante adequado "é aquele que tem um 'compromisso com a causa' daqueles que representa. 'Compromisso com a causa' não se limita apenas às 'causas' (relações processuais) em trâmite no Judiciário. Um verdadeiro 'compromisso' encerra uma série de atividades que deve desenvolver para a sua própria razão de existência" (VIGLIAR, José Marcelo de Menezes, "Defendant class action brasileira: limites propostos para o 'Código de Processos Coletivos"”, in GRINOVER, Ada Pellegrini e outros (coord.). Direito Processual Coletivo e anteprojeto de Código Brasileiro de Processos Coletivos. São Paulo: RT, 2007, p. 318).
} 
Uma das formas de fiscalização é a observância estrita da adequação dessa representação. Os requisitos da adequação podem ser de duas naturezas: objetiva ou subjetiva. A primeira ocorre quando a própria lei os especifica, anotando quais as características que deve ter o representante para tanto. No sistema brasileiro atualmente em vigor, entende-se existir previsão da representatividade adequada, no que toca à legitimação ativa do grupo, ainda que não expressa pela lei nesse sentido. A doutrina extrai esse instituto da especificação, pela lei brasileira, de que as sociedades e associações, para figurarem como autoras da ação coletiva, devem ter tempo mínimo de constituição e de seus estatutos sociais deve constar, como finalidade, a proteção dos direitos envolvidos. $\mathrm{Ou}$ seja, nesse caso específico, deve o juiz analisar, de acordo com os estritos termos da lei, se existe pertinência temática entre o que consta do estatuto social das associações e o que ela pretende tutelar em juízo, configurando exigência ope legis da adequada representação, pois a própria lei já estabelece critérios suficientes para que a adequação seja afirmada ${ }^{78}$.

É necessário observar que a análise restrita de exigências legais não evitará a ocorrência de fraudes, até porque o que se insere no estatuto social de uma sociedade ou associação é obra dos próprios associados e não tem qualquer fiscalização dos órgãos públicos ${ }^{79}$. Assim, esse meio de aferição da representatividade adequada é vago e não permite a efetiva fiscalização do instituto, pois não se pode esperar que determinados requisitos formais garantam a defesa efetiva dos direitos da coletividade, pelo que há necessidade de controle das atividades e da conduta do representante ${ }^{80}$.

Os critérios subjetivos de aferição da representatividade adequada, nos quais repousa a maior preocupação doutrinária, em vista do que antes se especificou, são: credibilidade, capacidade, prestígio, experiência do legitimado, histórico na proteção

\footnotetext{
${ }^{78}$ A legitimidade das associações será estudada na parte subsequente deste trabalho, que tratará da legitimidade. Contudo, essa disposição trazida pela lei brasileira é importante para se verificar no que consiste o critério objetivo assinalado pela doutrina.

${ }^{79}$ Anote-se que evitar-se as fraudes não é o objetivo principal do instituto da representatividade adequada, como aduz Gidi, ao tratar do collusive suit. Segundo o autor, se houver fraude, não haverá jurisdição e sequer lide (V. GIDI, Antonio. A Class Action como instrumento ...., Op. Cit., p. 107/108). O objetivo principal é, diferentemente, o de garantir a maior efetividade possível na proteção dos interesses transindividuais, porque uma representação inadequada prejudica os interesses do grupo, e a fraude é apenas uma das formas pelas quais o prejuízo aos direitos do grupo pode ocorrer.

${ }^{80}$ Cf. VIOLIN, Jordão. Ação Coletiva Passiva: fundamentos e perfis. Salvador: Editora Juspodivm, 2008, p. 72/73. De acordo com o autor, fica evidente "que legitimação ativa não se confunde com representação adequada. A previsão pelo legislador de um rol de legitimados não implica a presunção de que tais entidades sejam representantes adequadas. Tal aferição deve ser feita no curso do processo, tomando-se em conta as peculiaridades do caso concreto".
} 
judicial ou extrajudicial dos interesses do grupo, conduta em outros processos, coincidência entre interesses, tempo de instituição da associação, representatividade do indivíduo frente ao grupo ${ }^{81}$. Essas circunstâncias deveriam ser analisadas no caso concreto pelo magistrado, ou seja, mediante a persecução quanto à vida daquela pessoa ou daquela associação, não só individualmente, mas também em face da situação jurídica de direito material trazida ao Judiciário. Ou seja, não basta o representante ser sério e honesto, mas efetivamente ele deve ter aptidão para a defesa dos interesses do grupo.

Desta feita, o critério objetivo, individualmente considerado, pode provocar distorções do instituto, pois ele não analisará, de fato, a relação jurídica de direito material, mas apenas observará o preenchimento formal de uma exigência legal. Cappelletti anota que Itália e França tentaram, na década de 70, legislar sobre o que seria a representatividade adequada, mas, como ressalta, "it would be absurd to expect legislation to provide complete and uniform answers to this problem”, pois é imprescindível a análise judicial baseada em critérios variados como seriedade, honestidade, análise do passado do indivíduo, dentre outros ${ }^{82}$. De igual modo, Barbosa Moreira, no Brasil, já defendia, em 1984, que a lei deveria estabelecer, em termos expressos, como se daria o poder de iniciativa para a ação coletiva, mas anotava que isso deveria se dar "em termos flexíveis, reservada ao juiz margem razoável de liberdade do exame de cada espécie" ${ }^{\circledR 3}$, o que nada mais é do que a análise judicial da adequação da representatividade.

Assim, é a representatividade adequada um instituto fundamental, por meio do qual se certificará a seriedade e a aptidão daquele que atua judicialmente para pleitear a defesa dos interesses de um grupo, já que o instituto "exprime a relação de consonância entre e relevância de um interesse dentro do ordenamento e a postura de seu porta-voz em juízo" ${ }^{84}$. Mediante sua observância, e aqui se evidencia ser o critério subjetivo muito importante, pois a lei não consegue abarcar todos os critérios necessários e mutáveis, conforme o caso e a evolução social - para sua aferição, estarão asseguradas a qualidade, a seriedade e a idoneidade desse legitimado; desse modo, haverá segurança de

\footnotetext{
${ }^{81}$ Cf. MENDES, Aluisio Gonçalves de Castro, "O Anteprojeto de Código Brasileiro de Processos Coletivos: visão geral e aspectos sensíveis", in GRINOVER, Ada Pellegrini e outros (coord.). Direito Processual Coletivo e anteprojeto de Código Brasileiro de Processos Coletivos, São Paulo, RT, 2007, p. 26.

${ }^{82}$ CAPPELLETTI, Mauro. The judicial process ...., Op. Cit., p. 305/306. Como completa de forma figurativa o jurista, "adapting a legislative and rigidly uniform solution would be like using the axe of the woodman to perform delicate surgery".

${ }^{83}$ V. BARBOSA MOREIRA. “Tutela constitucional ....”, Op. Cit., p. 204.

${ }^{84}$ VIOLIN, Jordão. Ação Coletiva Passiva..., Op. Cit., p. 76.
} 
que o direito está sendo corretamente defendido em juízo. Diante disso, não se vislumbra justificativa plausível para que qualquer legislação que verse sobre direitos coletivos não coloque a representatividade adequada dentre os princípios dos processos voltados a sua defesa, porque ele é intrínseco ao próprio conceito das ações representativas.

\subsection{Sistema de common law}

Após a identificação precisa do que venha a ser a representatividade adequada, necessário se faz analisar como é o tratamento do instituto - em termos processuais - nos ordenamentos de common law; para tanto, aqui se utilizará o norteamericano como paradigma. Naquele sistema, o instituto tem relevância e aplicação há muito tempo, desde a edição dos primeiros dispositivos legais atinentes aos processos coletivos, pois sempre estave incrustada a ideia de que esse tipo de ação era representativa e, assim, a adequação desse representante era uma de suas principais facetas.

No ordenamento norte-americano, como se anotou no capítulo anterior, a adequação do representante, ou seja, do autor da ação coletiva, é requisito para a certificação da ação (requisito (a)(4)), de maneira que nenhum processo pode prosseguir sem a afirmação expressa do juiz quanto à sua existência, na fase de certificação, o que já revela a importância de sua observância.

Gidi explicita, quanto a esse aspecto, que o sistema norte-americano criou esse mecanismo, pois está menos interessado em criar ficções legais do que trazer à análise a realidade dos fatos. Por isso, criou "meios para assegurar que o representante defenda adequadamente tais interesses, garantindo ao grupo um efetivo e realista direito de ser ouvido coletivamente em juízo", minimizando, com isso, a colusão e assegurando que todas as questões sejam trazidas ao Judiciário ${ }^{85}$.

Importante anotar que o representante não precisa de autorização do grupo ou dos titulares do direito para agir, bastando ser membro da classe ${ }^{86}$, preencher os

\footnotetext{
${ }^{85}$ Cf. GIDI, Antonio. A Class Action como ...., Op. Cit., p. 100.

${ }^{86}$ Interessante observar que o requisito de ser membro da classe, existente no ordenamento norte-americano, não é comum a todos os ordenamentos. Na lição já trazida neste capítulo, Fiss aponta as vantagens do portavoz ser alheio ao grupo, vendo nisso uma capacidade de isenção e de menor envolvimento emocional, o que poderia contribuir para o sucesso da demanda. No Brasil, a maioria das ações coletivas, como se verá no
} 
requisitos especificados na Rule e demonstrar sua adequação para a função, o que é um ônus seu na fase de certificação da ação coletiva. Diante disso, revela-se essencial a verificação concreta e efetiva pelo juiz da adequação, sem o que poderá, em vista da extensão dos efeitos da coisa julgada, prejudicar indivíduos que não foram corretamente representados, violando o princípio constitucional do devido processo legal ${ }^{87}$.

Como ponderam, nesse sentido, Klonoff e Bilich, a decisão sobre a representação adequada é um julgamento de admissibilidade da ação, tarefa bastante difícil e delicada ${ }^{88}$. Caso não exista a certeza quanto à adequação, o juiz pode limitar o grupo ou mesmo rejeitar a admissibilidade daquela ação coletiva, transformando-a em individual. Ou seja, não basta simplesmente verificar que o representante tem os requisitos individuais para a função; o juiz também deve verificar se o grupo está adequadamente representado por ele, se ele não defende um determinado segmento da classe em detrimento de outro, se ele traz a juízo e tem aptidão para defender realmente o que aquela classe busca, e não o que, eventualmente, ele pretende, mas não é de interesse comum dos membros.

Importante salientar, quanto a esse aspecto, na linha do explicitado por Gidi $^{89}$, que os interesses do representante devem estar sintonizados com os do grupo. Na hipótese de existência de conflitos internos, o juiz pode dividir o grupo em subgrupos, fazer intervir outros representantes, redefinir o grupo ou manter a ação coletiva parcial. Todavia, o fato de alguns estarem pessoalmente de acordo com a conduta da outra parte não inviabiliza necessariamente o cabimento da ação, porque deve ser buscado sempre o objetivo mais homogêneo do grupo.

Não é somente nessa fase inicial de certificação que o controle da adequação da representatividade mostra-se necessário, pois essa tarefa incumbe ao juiz durante todo o processo, não sendo questão apta à preclusão, pois o juiz pode analisá-la, de

capítulo seguinte, é promovida pelo Ministério Público, mas, ainda quando não por esse órgão, os legitimados são associações e entidades da sociedade civil, não havendo previsão legal, como nos Estados Unidos da América, da legitimação de qualquer membro do grupo.

${ }^{87}$ Nesse sentido, GRINOVER, Ada Pellegrini, "A tutela jurisdicional dos interesses difusos no direito comparado", in A tutela dos interesses difusos, São Paulo: Max Limonad, 1984, p. 78/84.

${ }^{88}$ Ressaltam que "the judge should consider whether the definition will serve the purpose for which the class is certified. The definition should not, therefore, exclude a substantial number of persons with claims similar to those persons included in the class" (KLONOFF, Robert H., BILICH, Edward K. M., Class actions and other ...., Op. Cit., p. 42).

${ }^{89}$ V. GIDI, Antonio. A Class Action como instrumento ...., Op. Cit., p. 118/119. 
ofício, a qualquer momento. Como ressalta Gidi, não há necessidade de o representante ser o melhor representante possível, mas deve ter dois elementos qualitativos: aptidão para tutelar vigorosamente os interesses do grupo e ausência de antagonismo com esses interesses ${ }^{90}$.

$\mathrm{Na}$ jurisprudência norte-americana, a representatividade adequada é comumente tratada nos Tribunais, sempre com o objetivo de que os direitos coletivos envolvidos sejam corretamente tutelados. A título de exemplificação, interessante ser mencionado o caso Johnson v. Uncle Ben's Inc (628 F.2d 419), julgado em 17 de outubro de 1980 pela United States Court of Appeals, Fifth Circuit. Trata-se de uma class action que versava sobre a discriminação na contratação de empregados negros e de origem mexicana pela empresa Uncle Ben's. Em um primeiro momento, o juiz do caso entendeu que o autor representava adequadamente os interesses de ambos os grupos (negros e mexicanos). Todavia, na Corte de Apelação, decidiu-se não estarem os mexicanos corretamente representados, pois nem mesmo o número de empregados dessa origem - a demonstrar a discriminação - havia sido trazido ao processo. Assim, por ser obrigação do Tribunal fiscalizar com rigor a adequação da representação, houve por bem que o juiz deveria ter subdividido a classe, não certificando a ação em relação aos mexicanos; assim, ao final, decidiu-se que, em relação a eles, não haveria formação de coisa julgada, garantindo, com isso, o devido processo legal em relação àqueles não representados ${ }^{91}$.

\footnotetext{
${ }^{90}$ De acordo com o autor, o juiz "deverá acompanhar todas as fases do processo com atenção, controlando de perto todas as atividades das partes. A necessidade de controle judicial é potencializada pelo fato de que o representante age independentemente de autorização e fora do controle dos representados". Anota ainda o autor que é interesse da própria parte contrária zelar pela representatividade adequada, pois, além da necessária demonstração de boa-fé, só então ela terá uma decisão forte e válida perante os integrantes do grupo. Segundo o autor, as impugnações mais comuns são conhecimento (excesso ou falta), conduta imoral, ilícita ou antiética, condição física, idade e condição financeira (para pagamento de custas) (GIDI, Antonio. A Class Action como instrumento ...., Op. Cit., p. 101/3 e 108).

91 Segue a íntegra da decisão da Corte de Apelação no que toca a esse ponto: "12. The district court originally, and at the time quite correctly, determined that plaintiff would adequately represent the certified class of blacks and Mexican-Americans. At trial, however, representation of the class of Mexican-Americans was not adequate. The thrust of plaintiffs' direct case concerned the situation involving black employees. Although this may well have been necessary on the issue of promotion considering the small number of Mexican-Americans employed by Uncle Ben's, plaintiffs' preoccupation with the issue of black promotion seemingly led them to omit to introduce into evidence the number of Mexican-Americans hired by Uncle Ben's.

13. Under Rule 23 of the Federal Rules of Civil Procedure, the trial court has a duty to supervise plaintiffs' presentation to safeguard the rights of the class being represented. Grigsby v. Northern Mississippi Medical Center, Inc., 586 F.2d 457, 462 (5th Cir. 1978); Guerine v. J \& W Investment, Inc., 544 F.2d 863, 864-65 (5th Cir. 1977). When it became apparent that plaintiffs did not adequately represent the MexicanAmericans, the trial court should have taken action such as dividing the certified class into a separate subclass for the Mexican-American members, see Fed.R.Civ.P. 23(c)(4), decertifying that class, or certifying a second class. To remedy the trial court's failure in this respect we now hold that dismissal of all claims
} 
Um outro julgado interessante de ser trazido para revelar a postura da jurisprudência norte-americana é o caso Gonzales v. Cassidy (474 F.2d 67), julgado em 15 de fevereiro de 1973 pela United States Court of Appeals, Fifth Circuit. Trata-se de uma ação de classe promovida por taxistas envolvidos em acidentes que perdem sua habilitação, por ausência de seguro. Nesse caso, discutiu-se a adequação da representação em collateral attack, ou seja, após o trânsito em julgado de uma decisão que, supostamente, havia sido promovida por um representante adequado. O Tribunal deixou assente que, para a verificação da representatividade adequada, duas perguntas deveriam ser feitas: “(1) Did the trial court in the first suit correctly determine, initially, that the representative would adequately represent the class? and (2) Does it appear, after the termination of the suit, that the class representative adequately protected the interest of the class?". Somente com as duas respostas positivas, a revelar que o controle da adequação da representação se deu durante todo o processo, e não só na fase inicial, é que se pode considerar o caso efetivamente julgado em relação aos membros ausentes, estendendo sobre eles o manto da coisa julgada. Isso não existiu no caso mencionado, pois, a par de o representante revelarse, a princípio, adequado, ao final assim não se mostrou, porque não houve defesa vigorosa e tenaz dos interesses da classe, mas apenas daqueles que pessoalmente lhe interessavam, por terem situação de fato análoga à sua ${ }^{92}$.

Com essa rígida verificação da representatividade adequada pelo magistrado, assegura-se que se traga a real visão dos interesses do grupo para dentro do processo, garantindo, assim, que o princípio do devido processo legal - que é um princípio também daquele ordenamento - seja respeitado. Isso porque um representante inadequado, ainda que dotado de boa-fé, equivale à ausência de um representante, o que prejudicará os interesses do grupo.

É de se concluir, destarte, que o instituto é um dos mais relevantes nos sistemas de common law, o que justifica a importância dada a ele por aqueles

regarding Mexican-Americans is without prejudice. This judgment does not have res judicata effect against them in light of plaintiffs' total failure adequately to represent them. Sam Fox Publishing Co. v. United States, 366 U.S. 683, 691, 81 S.Ct. 1309, 1314, 6 L.Ed.2d 604 (1961) ("the judgment in a class action will bind only those members of the class whose interests have been adequately represented by existing parties to the litigation"); Grigsby v. North Mississippi Medical Center, 586 F.2d at 461-62; Gonzales v. Cassidy, 474 F.2d 67, 73-75 (5th Cir. 1973)" (http://openjurist.org/628/f2d/419/johnson-v-uncle-bens-inc).

$92 \mathrm{http} / / /$ openjurist.org/474/f2d/67/gonzales-v-w-cassidy-iii 
ordenamentos, que veem nele a melhor forma de garantir que os objetivos das ações coletivas sejam atingidos, sem prejudicar os interesses dos membros ausentes, que, então, terão assegurada a fiel defesa de seus interesses, no plano processual, mediante uma rigorosa observância da representatividade adequada, durante todo o iter processual.

\subsection{Tratamento do instituto no Brasil}

No Brasil, a representatividade adequada tem estudo difuso e pouca aplicação, constituindo instituto cuja importância tem crescido somente nos últimos anos, devido ao empenho dos estudiosos em alçá-lo como princípio da tutela jurisdicional coletiva, como de fato deveria ser.

Até o presente momento, o instituto não consta como requisito expresso - para a ação coletiva em nenhuma das leis atinentes ao tema, no que se inclui a Lei da Ação Civil Pública e o Código de Defesa do Consumidor. Esses dispositivos legais passam a largo da adequação da representação, mesmo quando tratam da questão da legitimidade, uma das aplicações mais prementes do instituto, como antes se ressaltou e se verá no próximo capítulo.

Diante da falta de previsão legal, parte da doutrina entendia que o instituto era mesmo inexistente no processo coletivo ou que o juiz era impedido de fazê-lo observar. Muito já se afirmou que sua ocorrência, no processo coletivo brasileiro, era uma presunção iuris et de iure, pois não deveria haver controle pelo juiz do que o legislador já estabelecera, bastando, pois, o preenchimento daqueles requisitos formais (o mencionado sistema ope legis de verificação). Isso porque o Código de Defesa do Consumidor apenas determina, em seu artigo 82, IV, que as associações legitimadas são aquelas "legalmente constituídas há pelo menos um ano e que incluam entre seus fins institucionais a defesa dos interesses e direitos protegidos por este código" ${ }^{93}$. Assim, a adequação da representação pela associação viria desse critério estabelecido pela lei, em relação ao qual nada poderia

\footnotetext{
93 Nesse sentido, o Projeto unificador da disciplina manteve, em linhas gerais, o que já consta da lei. Estabelece o seu artigo $6^{\circ}$, VII serem legítimas as "associações civis e as fundações de direito privado legalmente constituídas e em funcionamento há pelo menos um ano, para a defesa de interesses ou direitos relacionados com seus fins institucionais, dispensadas a autorização assemblear ou pessoal e a apresentação do rol nominal dos associados ou membros".
} 
fazer o magistrado, pois, mediante o simples preenchimento do requisito formal, deveria reconhecer a existência da adequada representação.

Todavia, esse critério não pode ser analisado de maneira simplística, pois ele dá abertura para uma análise mais aprofundada do instituto, ainda que não o faça expressamente. Diante do que se coloca, verifica-se a necessidade de as associações terem, em seus fins institucionais, pertinência temática com os direitos que buscam garantir, o que deve ser extensivo a todos os legitimados, dando, de certa forma, ensejo à análise concreta da adequação da representação do grupo. Essa circunstância já é entendida, pelo Supremo Tribunal Federal como requisito, para a propositura de ação direta de inconstitucionalidade ${ }^{94}$, de modo que, ao menos quanto a essa modalidade de ação, já existe um início de controle judicial da representatividade.

Contudo, a análise da representatividade adequada nos Tribunais brasileiros tem restado adstrita à questão da pertinência temática, pois se verifica apenas o critério legal, ou seja, se o objeto a ser tutelado enquadra-se dentre os fins institucionais ou sociais daquele legitimado, não se fazendo qualquer perquirição a respeito dos outros critérios, como seriedade, aptidão, atuação na defesa dos direitos envolvidos. Dessa forma, mesmo quando nomeada representatividade adequada pelos Tribunais, a aferição dá-se apenas em níveis de pertinência temática formal. Isso resta evidente por trecho da ementa de julgado de recurso especial pelo Superior Tribunal de Justiça, relatado pelo Ministro Luiz Fux", em que se anota que "a cooperativa preenche o requisito oriundo do direito anglo-saxônico da representatividade adequada para promover ação em prol dos seus cooperados posto atingir as suas finalidades institucionais".

No entanto, a parcela da doutrina que entende não existir espaço para o controle judicial - e efetivo, baseado também em critérios subjetivos - da representatividade tem diminuído, existindo expressiva corrente que entende haver

\footnotetext{
${ }^{94}$ V. Dentre outros, no STF, ADI 2649/DF, Rel. Min. Carmen Lúcia, j. 08.05.08; ADI 15/DF, Rel. Min. Sepúlveda Pertence, j. 14.06.07; ADI 2903/PB, Rel. Min. Celso de Mello, j. 01.12.05.

No sentido de se criar essa obrigatoriedade, Mirra já defendeu que deveria ser inserida como critério "demonstração da realização efetiva de atividades concretas em prol dos direitos incluídos entre os fins institucionais" (MIRRA, Álvaro Luiz Valery, "Associações civis e a defesa dos ...”, Op. Cit., p. 124), o que nada mais é do que analisar-se subjetivamente a adequação da representação, mediante a verificação da conduta do legitimado na defesa dos interesses envolvidos, situação absolutamente necessária para a efetiva proteção dos direitos coletivos.

${ }_{95}^{95}$ STJ, REsp 651.064/DF, Rel. Min. Luiz Fux, Primeira Turma, j. 15/03/2005, DJ 25/04/2005, p. 240.
} 
permissão legal para tanto, mesmo diante da atual lei posta ${ }^{96}$ e não só quando expressamente assim ela estabelece tal possibilidade. Não se pode olvidar que o magistrado deve ver-se inserido em um contexto constitucional, de forma a ser seu dever a plena observância do devido processo legal, em sua ótica coletiva, já, há muito, salientada por Cappelletti ${ }^{97}$. Diante disso, seria permitido ao magistrado brasileiro, tal qual ao norteamericano e pelas mesmas razões, aferir se existe a adequação de representatividade do autor da ação coletiva, ainda que não se tenha essa imposição expressa pela legislação, pois, com isso, o juiz estaria garantindo a correta e efetiva defesa judicial dos interesses coletivos $^{98}$.

De acordo com Susana Henriques da Costa, tanto no aspecto quantitativo quanto no qualitativo, o controle judicial dessa adequação deve ser permitido. O primeiro aspecto deve impor a conclusão de que não é racional deixar que a máquina judiciária seja movimentada e despenda tempo em processo que será eventualmente reproposto por outro legitimado. Isso pode ser evitado com a análise do potencial representativo do autor, por meio do qual se afastarão demandas inidôneas e o risco de existirem decisões contraditórias. No aspecto qualitativo, apesar de haver técnicas de extensão de coisa julgada para evitar danos a indivíduos não participantes da demanda, essas técnicas não lidam com a má redação da peça ou a má argumentação, mas apenas com aspectos de prova, de forma que essas outras atuações inadequadas fogem ao controle judicial, se não imposta a necessidade de observância da representatividade adequada ${ }^{99}$.

\footnotetext{
96 A única exceção legal está prevista no Código de Defesa do Consumidor é do artigo $82, \S 1^{\circ}$, que estabelece que o requisito da pré-constituição pode ser dispensado pelo juiz, nas ações relativas a direitos individuais homogêneos, quando houver manifesto interesse social evidenciado pela dimensão ou característica do dano, ou pela relevância do bem jurídico a ser protegido. Ou seja, relativamente a interesses difusos ou coletivos, ou quando os individuais homogêneos não forem considerados relevantes, pelo critério da lei, em tese, jamais poderá prosseguir a ação coletiva sem a observância do requisito legal.

${ }^{97}$ V. CAPPELLETTI, Mauro. "Formações sociais e interesses .....", Op. Cit..

A Professora Ada, em artigo publicado em 1986, também já tentava impor a necessidade de análise dos processos coletivos sob essa ótica, anotando que o devido processo legal deveria ser visto não mais como individual, um direito subjetivo das partes, para transformar-se em social, ou seja, garantia das partes e do justo processo (v. GRINOVER, Ada Pellegrini, "As garantias constitucionais do processo nas ações coletivas”. Revista de Processo, v. 11, n. 43, jul-set/1986, p. 19-30).

${ }^{98}$ Quanto a esse aspecto, Gidi anota, refutando argumento daqueles que acreditam não ser o juiz brasileiro apto para tanto, que ele certamente não é igual ao americano, mas não pode ser completamente inerme e incapacitado de controlar a adequação do representante com auxílio de instrumentos cuidadosamente concebidos para facilitar sua tarefa (GIDI, Antonio. A representatividade ...., Op. Cit., p. 65). E não há dúvidas de que o Brasil deve impor essa responsabilidade a seus magistrados, porque é da própria essência dos processos coletivos um juiz atuante nesse sentido, sob pena de não garantir-se proteção alguma.

${ }^{99}$ V. COSTA, Susana Henriques da. "O Controle Judicial da representatividade ...”, Op. Cit., p. 975/976.
} 
Há posicionamento doutrinário que entende ser possível o controle da adequação da representação com base no artigo 13 do Código de Processo Civil ${ }^{100}$, que prevê o controle da representação das partes pelo magistrado ${ }^{101}$, mas não entendemos justificável essa posição, pois o dispositivo do diploma processual versa sobre a representação clássica, que, como antes se anotou, é distinta da ora estudada. Assim, a razão para que se permita o controle da adequação da representatividade não está no processo civil clássico, que não pode ter seus conceitos puramente transportados aos processos coletivos, mas na própria natureza desses direitos e da ação voltada à sua defesa, que é representativa.

Nessa linha evolutiva, estudiosos do tema haviam elaborado um Anteprojeto de Código Brasileiro de Direitos Coletivos, que trazia, dentre os princípios da tutela jurisdicional coletiva, o da representatividade adequada (artigo $2^{\circ}$, inciso I), tentando, com isso, impor a efetiva observância do instituto no ordenamento brasileiro, não só por aqueles juízes que entenderem já existente essa possibilidade por força dos preceitos constitucionais, mas de maneira geral no ordenamento.

No entanto, o Projeto de Lei elaborado pelo Ministério da Justiça e enviado ao Congresso no ano de 2009 não fez constar dispositivo análogo, bem como qualquer menção e aplicação possível da representatividade adequada, o que é de se lamentar, pois o instituto, como antes se viu, é de importância fundamental para garantir-se a efetividade e a participação real dos membros ausentes da classe nesse tipo de ação, que tem como principal característica ser representativa.

De qualquer modo, é certo que mesmo o mencionado Anteprojeto não havia definido consequências maiores para a falta de observância da adequada representação, a não ser a possibilidade de se modificar o autor da ação coletiva, para que outro legitimado a assumisse. $\mathrm{O}$ seu tratamento, naquele texto, tinha sido circunscrito ao tema da legitimação, uma vez que tinha havido expressiva ampliação do rol de legitimados, incluindo-se a pessoa física, que, para poder ser autora da ação coletiva,

\footnotetext{
100 "Art. 13. Verificando a incapacidade processual ou a irregularidade da representação das partes, o juiz, suspendendo o processo, marcará prazo razoável para ser sanado o defeito. Não sendo cumprido o despacho dentro do prazo, se a providência couber: I - ao autor, o juiz decretará a nulidade do processo; II - ao réu, reputar-se-á revel; III - ao terceiro, será excluído do processo".

${ }^{101}$ V. VIOLIN, Jordão. Ação Coletiva Passiva..., Op. Cit., p. 80/82.
} 
deveria circunscrever-se ao princípio ora sob exame. Todavia, legitimação da pessoa física também não constou do Projeto em tramitação, pois, de acordo com seus autores, "o país ainda não está preparado para um instrumento desse tipo", o que, certamente, fez retroceder muito o que havia se construído até então. Essa especial questão será abordada de maneira crítica no capítulo subsequente, que tratará exclusivamente da legitimidade.

O Anteprojeto também não havia estabelecido, ao contrário do que existe nos ordenamentos de common law, a obrigatoriedade de aferição do requisito, apenas tendo determinado que o magistrado deve, antes da fase instrutória, decidir se a ação tem condições de prosseguir na forma coletiva. Esse requisito consta do Projeto enviado ao Congresso, também sem delimitação do que sejam essas condições. Contudo, como naquele Anteprojeto a representatividade adequada era requisito, seria certamente obrigatório o seu atendimento, o que, a princípio, não se poderia exigir diante do texto do Projeto.

No entanto, independentemente da lei projetada, é certo que a aferição dos requisitos de admissibilidade da demanda coletiva pode e deve ser realizada no despacho saneador, ao qual se impõe, mais do que apontar a mera inexistência de obstáculos, externar a regularidade de seus requisitos fundamentais, de maneira motivada ${ }^{102}$. Assim, apesar de inexistir a expressa obrigatoriedade de observância da representatividade adequada, ela é inerente ao sistema e pode ser aplicada em inúmeras questões pelo magistrado, pois, como bem aduz Fiss, "o papel judicial é limitado pela existência de valores constitucionais e a função das cortes é conferir significado a esses valores. (...) A ausência de especificidade textual não torna os valores menos reais ou importantes". Um texto não específico torna a atividade de dar "significado mais árdua:

\footnotetext{
${ }^{102} \mathrm{O}$ artigo 20 do Projeto de lei estabelece que, se não obtida a conciliação ou não for utilizado outro meio para a solução do conflito, o juiz, fundamentadamente, dentro outros aspectos, que se alinham ao que determina o artigo 331, §2º , do Código de Processo Civil quanto ao despacho saneador, "decidirá se o processo tem condições de prosseguir na forma coletiva”. Nesse momento, não há dúvidas quanto à possibilidade - a nosso ver, dever - de análise da adequação da representação, que é intrínseca à modalidade de tutela levada a juízo e constitui, pois, verdadeiro princípio, ainda que não expresso na lei, de observância obrigatória do julgador.

Ressalte-se que o juiz pode, tal qual faz em relação às demais condições da ação, indeferir a petição inicial, por ausência de representação adequada, ou determinar que ela seja aditada, para que se faça estar presente esse requisito, antes mesmo da citação do réu. Todavia, caso a citação seja simplesmente determinada, a análise expressa do requisito deverá ser feita no saneador, pois se trata de uma questão prejudicial à decisão de mérito e até esse momento deve ser resolvida.
} 
menos confiança pode ser conferida ao texto" ${ }^{103}$. Assim, a ausência de indicação expressa desse instituto como princípio da tutela coletiva só acarreta a dificuldade de justificar sua aplicação pelo magistrado, que, se tiver consciência do verdadeiro papel das ações coletivas e da própria natureza delas, certamente o aplicará. Desta feita, verifica-se que a especialização dos magistrados também é medida bastante salutar para a efetiva tutela dos direitos coletivos.

Essa possibilidade de aplicação do instituto segue, ademais, uma linha de aumento dos poderes do magistrado, que é uma tendência generalizada do processo civil e é mais premente nos processos coletivos ${ }^{104}$, pode - e deve - verificar a presença de adequada representação, para evitar que vícios processuais maculem ou impeçam a solução da relação jurídica material trazida a juízo. Assim, a observância do instituto, ainda que somente nas hipóteses em que já existe abertura legal para tanto, acarretará a atuação positiva do processo, na garantia de efetivação dos direitos materiais.

É de se ressaltar que, quando do saneamento do feito, o juiz deverá verificar, por óbvio, a presença de todas as condições da ação, tal como faz nos processos individuais. Ausente alguma condição, poderá deixar de analisar a representatividade adequada, por essa restar essa prejudicada. Contudo, caso vislumbre sua inexistência, seria salutar deixar sua posição externalizada, para facilitar, inclusive, a apreciação do feito em segundo grau de jurisdição, na hipótese de interposição de recurso, já que esse pode afastar a extinção por um aspecto, mas mantê-la por esse outro.

\footnotetext{
${ }^{103}$ V. FISS, Owen. Um novo Processo ...., Op. Cit., p. 38/39.

${ }^{104}$ Nesse sentido, Cruz e Tucci anota que "é importante ressaltar que, no âmbito das ações coletivas, torna-se relevante a verificação, pelos Juízes, durante toda a tramitação do processo, do comportamento processual do legitimado, que 'representa' todo o grupo, visto que a trama entre os litigantes acarreta gravíssima ofensa às garantias do Devido Processo Legal, que inclusive protegem os terceiros. Não é preciso destacar que o papel reservado aos órgãos jurisdicionais pelas legislações processuais modernas (inclusive a nossa) sempre foi o de um Juiz ativo, cabendo-lhe, entre outras relevantes incumbências, velar pela conduta processual dos litigantes, prevenindo ou reprimindo qualquer ato atentatório à dignidade da justiça" (CRUZ E TUCCI, José Rogério. "Garantias Constitucionais do processo ....", Op. Cit., p. 79).

No mesmo sentido, Américo Freire salienta que "no processo coletivo, além dessa necessidade de uma intensa participação do juiz na colheita das provas, é preciso ir além e entender ser possível ao magistrado utilizar todos os meios e recursos necessários para a preservação do interesse difuso ou coletivo posto na causa, sendo que essa conclusão pode ser extraída sistematicamente de nosso ordenamento jurídico" (FREIRE JÚNIOR, Américo Bedê. Os poderes do juiz nas ações coletivas e breves sugestões de lege ferenda ao aprimoramento no processo coletivo. Revista de Processo, São Paulo, v. 29, n. 117, set-out/2004, p. 132). Ainda a esse respeito, Jordão Violin anota ser princípio da tutela coletiva o ativismo judicial, pois "a nova função do juiz decorre do dever estatal de atuar as garantias constitucionais. Em função da importância reconhecida pelo direito positivo aos interesses coletivos lato sensu, o magistrado assume uma posição muito mais ativa, concretizadora de direitos fundamentais", o que abre brecha para a aferição da representatividade adequada (VIOLIN, Jordão. Ação Coletiva Passiva..., Op. Cit., p. 117/118).
} 
A representatividade adequada tem ainda especial importância no que toca às ações coletivas passivas, modalidade de ação admitida pela doutrina e pela jurisprudência, mas sem nenhuma menção expressa da lei. Neste ponto, importante salientar que o Anteprojeto de lei trazia disposições a respeito da ação coletiva passiva, assinalando a importância da representatividade adequada para tanto. Contudo, o Projeto em tramitação não as contempla, ignorando que essa modalidade de ação já efetivamente existe no nosso ordenamento e revela uma das mais importantes facetas de aplicação da representatividade adequada, já diante da lei posta, como se estudará especificamente ao cotejar o princípio com a legitimidade. A negativa de legislar-se a respeito somente irá trazer ainda maiores problemas no que toca à definição do pólo passivo desse tipo de ação, já admitida pela jurisprudência com base no direito posto, mas, às vezes, ainda controversa.

Desse modo, foi infeliz o Projeto de criação do Código Brasileiro de Processos Coletivos ao excluir a representatividade adequada de seus princípios e de seus regimentos, afastando a importância já existente do instituto em nosso ordenamento, essencial para a própria efetividade dessa modalidade de tutela. O instituto pode ser responsável por evitarem-se muitas das problemáticas e dos questionamentos existentes nos processos coletivos, especialmente quanto à possibilidade de a decisão atingir supostamente terceiros que não participaram, em nome próprio, da relação jurídica posta em juízo e não se viram corretamente representados por aquele legitimado que foi a juízo para tanto, como se verá no capítulo 5 deste estudo, que tratará da extensão dos efeitos da coisa julgada.

Assim, após o estudo expositivo do instituto nesta parte do trabalho, adentrar-se-á, nos próximos capítulos, o seu estudo crítico e propositivo em face da legitimidade ativa e passiva para as ações coletivas e de formação e extensão da coisa julgada, realizando-se um cotejamento também com o sistema norte-americano. Neles, serão feitas tanto referências às situações já existentes em que o instituto tem aplicação permitida ou não pela lei posta, como também proposições críticas de lege ferenda, sempre com o objetivo de verificarem-se os benefícios que a observância do instituto pode trazer para a eficácia da tutela dos direitos coletivos. 


\section{REPRESENTATIVIDADE ADEQUADA, LEGITIMIDADE E INTERESSE DE AGIR}

Após o estudo, nos capítulos anteriores, de forma expositiva e descritiva dos direitos transindividuais, da razão de sua defesa coletiva e do instituto puro da representatividade adequada, este trabalho objetiva adentrar a sua parte crítica e propositiva, analisando institutos específicos dos processos coletivos, para verificar como a observância da adequação de representação, verdadeiro princípio do processo coletivo, como antes se viu, pode nele interferir. Para tanto, o remanescente do trabalho será dividido em duas partes, associadas aos dois institutos processuais que apresentam características mais peculiares nos processos coletivos: a legitimidade, tratada neste capítulo, e a coisa julgada, no capítulo seguinte.

A análise da legitimidade em primeiro lugar se justifica, pois é nela que reside o maior grau de intersecção com a representatividade adequada, razão pela qual grande parte da doutrina analisa esse instituto, como antes se disse, como mero tópico da legitimidade, o que aqui se preferiu não fazer, para tentar-se definir o conceito puro de representatividade adequada, consoante explicitado no capítulo anterior. Todavia, após se ter estudado esse instituto isoladamente, seu confronto com a legitimidade é essencial, porque ele a integra.

\subsection{Premissa}

O que se pretende demonstrar, ao fim desse capítulo, é que a representatividade adequada já pode ser utilizada pelo ordenamento brasileiro, com base na lei posta, como critério de aferição de legitimidade, em relação a todos aqueles legitimados para os processos coletivos, e já se encontra em plena aplicação no que toca às ações coletivas passivas, não previstas legalmente, mas existentes de fato. $\mathrm{O}$ instituto, apesar de muitas vezes expressamente não nominado, já é, pois, utilizado nos processos coletivos e pode sê-lo ainda mais, diante da atual legislação.

Ademais, como proposições de lege ferenda, mas também como objetivo propositivo desse capítulo, buscar-se-á trazer elementos que comprovem que a 
representatividade adequada é instrumento de aplicação imprescindível para o efetivo julgamento de litígios envolvendo processos coletivos, sendo possível, mediante sua observância concreta, até mesmo ampliar o rol de legitimados, incluindo dentre eles a pessoa física.

Para tanto, esse capítulo terá início com o desenvolvimento do conceito de legitimidade no processo civil clássico, passando-se pela definição de legitimidade ordinária e extraordinária, e, posteriormente, adentrará o estudo expositivo da legitimidade nos processos coletivos, analisando, de modo crítico e em face da representatividade adequada, os principais legitimados e possíveis legitimados. Por fim, serão ainda estudadas as ações passivas, tudo de modo a atingir o escopo antes anotado.

\subsection{Legitimidade e interesse no processo civil clássico}

Para a análise da legitimidade, impõe-se, de antemão, centrar-se no conceito de parte, pois o legitimado será a parte (ativa ou passiva) em determinado processo. Na lição clássica de Chiovenda, "parte é aquele que demanda em seu próprio nome (ou em cujo nome é demandada) a atuação duma vontade da lei, e aquele em face de quem essa atuação é demandada"105.

E, para ser parte, a pessoa (física ou jurídica) deve ter legitimidade, pois só alcança a figura de parte aquele a quem a lei autoriza estar em juízo. Diante disso, extrai-se que legitimidade é "a qualidade para estar em juízo, como demandante ou demandado, em relação a determinado conflito trazido ao exame do juiz" ${ }^{106}$. A legitimidade é instituto de suma importância, pois é uma das condições da ação, ou seja, um dos requisitos mínimos e essenciais para que exista o processo, juntamente com o interesse processual e a possibilidade jurídica do pedido (artigo $3^{\circ}$ do Código de Processo Civil Brasileiro). Sem legitimidade, o mérito da demanda jamais será analisado, extinguindo-se o processo sem que se julgue a questão controvertida, por carência de ação (artigo 267, VI, do diploma processual brasileiro).

${ }^{105}$ CHIOVENDA, Giuseppe. Instituições de Direito Processual Civil, vol. 2, $3^{\text {a }}$ ed. São Paulo: Saraiva, 1969, p. 234.

${ }^{106}$ Cf. DINAMARCO, Cândido Rangel. Instituições de Direito Processual Civil, II, $2^{\text {a }}$ ed. São Paulo: Malheiros, 2002, p. 306. 
Em que pese o conceito de parte, como antes se anotou, refira-se exclusivamente à relação jurídica processual, pois só existe parte desde que exista lide, a regra geral utiliza como critério para demandar ou ser demandado (legitimidade ativa ou passiva) ser titular do direito material em controvérsia, existindo disposição legal expressa que determina que ninguém pode pleitear, em nome próprio, direito alheio (artigo $6^{\circ}$ do Código de Processo Civil), salvo exceções previstas em lei, dispositivo esse que traz o conceito de interesse de agir. Assim, o enfoque dado pela regra geral da lei é eminentemente individualista, na linha, ressalte-se, de todo o diploma processual, pois, a princípio, somente aquele que tem interesse direto na demanda pode ser parte ${ }^{107}$.

Essa legitimidade, a daquele que faz coincidir a parte com o titular da relação jurídica de direito material, é a chamada legitimidade ordinária. Nesse caso, alguém pleiteará em Juízo, em nome próprio, um direito próprio, e será diretamente atingido pela decisão, o que é o modo normal de acontecerem os fatos, não existindo nesse conceito nenhuma particularidade.

No entanto, como antes se ressaltou, o próprio artigo $6^{\circ}$ admite exceções à regra geral, de modo que existem casos em que não haverá a identidade entre o titular da relação jurídica e o participante do processo. Essa hipótese é a da chamada legitimidade extraordinária e pode se dar de duas formas: representação ou substituição. No primeiro caso, o representante pede (ou defende) em nome alheio um direito alheio, valendo-se de poderes que lhe foram conferidos pela lei ou pelo próprio representado, de modo voluntário. Nessa hipótese, a parte, em que pese não esteja "fisicamente" no processo, é o próprio representado, pois, aplicando-se a clássica lição de Chiovenda, é em nome dele que se está demandando ou sendo demandado ${ }^{108}$.

\footnotetext{
${ }^{107}$ Como ressalta Jordão Violin, "o individualismo processual, sintetizado no princípio de que somente o titular do direito material é legitimado a propor ação para tutelá-lo, encara o interesse como um patrimônio do indivíduo. Essa perspectiva privilegia a autonomia da vontade, na medida em que o próprio titular do direito decide como e em que momento buscar seus direitos, de acordo com critérios próprios de oportunidade e conveniência" (VIOLIN, Jordão. Ação Coletiva Passiva..., Op. Cit., p. 44).

${ }^{108}$ Cf. CHIOVENDA, Giuseppe. Instituições de ..., Op. Cit., p. 272.

A representação pode ser, pois, voluntária, ou seja, outorgada pelo representado ao representante para a prática de atos de sua vida civil, ou conferida pela lei, tal qual o caso do inventariante, como representante do espólio, do tutor, como representante do tutelado. Em qualquer caso, quem estará em juízo como parte é o representado, fazendo-se apenas se ouvir por meio do representante.
} 
Situação diferente é aquela da substituição processual. Nesse caso, o substituído atua no processo, em nome próprio, para defesa de um direito alheio, o do substituído. Há inúmeras autorizações legais para tanto, como a do gestor de negócios que age na defesa dos direitos do gerido (artigo 861 do Código Civil), a do denunciado da lide que defende em juízo os interesses do denunciante (artigos 71, I e 74 do Código de Processo Civil), a da promoção de ação civil decorrente de delito, pelo Ministério Público (artigo 68 do Código de Processo Penal). A esse rol poderiam ser acrescidas inúmeras outras hipóteses, mas como o escopo desse trabalho não é a discussão da legitimidade no processo civil clássico, mas, sim, apenas a realizarão um paralelo para se analisar a legitimidade coletiva, esses exemplos, longe de serem exaustivos, parecem suficientes para a compreensão do instituto.

De acordo com o antes mencionado artigo $6^{\circ}$ do diploma processual, para que a legitimação extraordinária seja possível, é imperioso que exista autorização legal, quando essa não decorrer da vontade da pessoa em nome de quem se pede. Muito se questiona sobre o que se faz necessário para tanto, sustentando sempre os autores que é imprescindível uma motivação para que se autorize alguém a pleitear algo em juízo em nome de outrem, sob pena de ofenderem-se os mais elementares princípios do direito. De qualquer forma, como, com exatidão, anotou Donaldo Armelin, não se pode estabelecer, $a$ priori, um rol de razões, pois "a casuística predomina sobre o influxo das mais variadas motivações" ${ }^{\prime 109}$. Diante disso, aos exemplos antes citados, inúmeros outros podem ser acrescidos, inclusive por força de alteração legislativa decorrente do incremento das relações sociais.

Ressalte-se que, por ser baseada no direito material essa autorização, configuradora do interesse do substituto processual, não significa que se deva analisar a legitimidade extraordinária a cada caso concreto, pois a autorização legal é suficiente para tanto, bastando o preenchimento dos requisitos especificados na norma para dar-se a substituição $^{110}$. Essa circunstância será de especial análise quando adiante se tratar da

\footnotetext{
${ }^{109}$ V. ARMELIN, Donaldo. Legitimidade para agir no direito processual civil brasileiro. São Paulo: RT, 1979, p. 121.

${ }^{110}$ Nesse sentido, Cassio Scarpinella salienta que "esse verdadeiro amálgama que exige legitimidade e interesse para agir, sobretudo quando se trata de situações de legitimidade extraordinária, acaba por revelar que só se pode cogitar de interesse (jurídico) para propositura de ação em nome próprio para pleitear direito alheio quando a condição de legitimidade para tanto estiver prevista no ordenamento jurídico"
} 
legitimidade coletiva, que é extraordinária, pois não é possível a aplicação dessa regra geral aos processos coletivos.

No caso de legitimação extraordinária por substituição, ao contrário do que ocorre quando da representação, o substituto é parte, pois é ele que pedirá ou em face dele que se fará pedido numa demanda ${ }^{111}$. No entanto, os efeitos dessa decisão, como se analisará no capítulo atinente à coisa julgada, recairão em face do titular da relação jurídica de direito material, como não poderia ser diferente, já que o substituto nada tem com a relação material objeto da controvérsia.

Assim, a legitimidade no processo civil clássico parte do pressuposto de que o processo é um ato de provocação individual, que ocorre entre duas pessoas individualizadas (ou grupos, mas sempre com participantes individualizados e especificados), para a defesa de direitos subjetivos, estritamente considerados pelos seus titulares de forma direta, salvo autorizações legais específicas.

\subsection{A legitimidade nos processos coletivos}

A legitimidade nos processos coletivos, em virtude da natureza material dos direitos envolvidos, que se afasta do individualismo tradicional, não pode valer-se da mesma técnica do processo civil clássico. Isso porque, consoante se viu no segundo capítulo, a essência da ação coletiva, em decorrência de sua natureza herdada do sistema de common law, é ser uma ação representativa, por meio da qual os titulares do direito posto sub judice não são aqueles que figuram como autores da ação coletiva, mas, sim, um

(SCARPINELla BUENO, Cassio. Partes e Terceiros no Processo Civil Brasileiro. São Paulo: Saraiva, 2003, p. 49).

${ }^{111}$ Interessante anotar, como bem recorda Chiovenda, que a condição de parte não permite ao substituto realizar todos os possíveis atos da parte, extraindo-se desses aqueles de cunho absolutamente pessoal. Nas palavras do mestre italiano, "dizer que o substituto processual é parte não implica dizer que ele possa realizar todas as atividades de parte. Pode haver atividades de parte a que a lei somente atribua importância desde que emanem daquele que é titular da relação substancial (juramento, confissão, renúncia aos atos, renúncia à ação, reconhecimento da ação), ou daquele que é representante ou órgão titular. Semelhantes atividades não as poderia exercer o substituto; a atividade dele é, pois, circunscrita por sua própria condição" (CHIOVENDA, Giuseppe. Instituições de ..., Op. Cit., p. 254).

De igual forma, salienta Donaldo Armelin que "os poderes deferidos ao substituto devem ser estritamente compatíveis com a outorga legal, ou seja, aqueles poderes indispensáveis para o desempenho de sua função processual normal (...). Se ao substituto processual lícito será postular judicialmente pelo direito alheio, defeso the será, em contrapartida, praticar no processo atos que impliquem, direta ou indiretamente, a disposição do direito questionado" (ARMELIN, Donaldo. Legitimidade para ..., Op. Cit., p. 134). 
representante apto a ser o porta-voz do grupo ou dos indivíduos interessados, quando não da própria sociedade.

Recordando o quanto se disse no capítulo 2, essa circunstância pode decorrer da numerosidade dos titulares dos direitos, que não podem ou não têm interesse de ir a juízo para defender-se, seja por uma impossibilidade prática de litisconsórcio, circunstância que foi uma das causas do desenvolvimento das ações coletivas, seja por critérios de conveniência de tratamento conjunto dos direitos. A justificativa também pode decorrer da indeterminação dos titulares dos direitos, como ocorre na hipótese dos direitos difusos, dos quais podem ser titulares todos os integrantes da sociedade ${ }^{112}$.

Assim, as leis que tratam dos processos relativos a direitos coletivos tiveram que inovar em relação à regra clássica de legitimidade, para permitir que um terceiro (representante adequado) pudesse agir em juízo em nome do grupo ou da classe que teve direitos violados.

No direito norte-americano, como noticia Salles, em trabalho comparativo entre os sistemas, o instituto que mais se aproxima da legitimidade é o standing, por meio do qual deve o autor da ação coletiva demonstrar que preenche os requisitos previstos na Rule 23, antes estudados, para que possa estar em juízo e ter, assim, se preenchidas as demais condições, certificada sua ação coletiva ${ }^{113}$.

No Brasil, a questão da natureza jurídica da legitimação nas ações coletivas costuma trazer alguma disputa na doutrina, sendo majoritário o entendimento de

\footnotetext{
${ }^{112}$ Nesse sentido, a lição de Barbosa Moreira, que afirma que, em virtude da natureza dos direitos materiais envolvidos, revela-se impraticável adoção da técnica tradicional, "consistente em fazer coincidir a legitimatio ad causam com a titularidade da relação jurídica litigiosa: há uma pluralidade de titulares, em regra numerosos e indeterminados, ou mesmo indetermináveis, ao menos para fins práticos. Cumpre portanto afastar in limine, por motivos óbvios, a eventualidade de atribuir-se à legitimação, em conjunto, à totalidade dos co-titulares, isto é, de situar o caso na área do litisconsórcio necessário”. Essa hipótese não seria de tutela coletiva, mas de tutela individual de todos em conjunto, o que de nada serviria para a natureza do processo. (BARBOSA MOREIRA, José Carlos. "Tutela constitucional ....", Op. Cit., p. 198).

${ }^{113}$ Segundo Salles, o standing extrai-se "da demonstração de o autor incluir-se entre aquelas pessoas que sofreram uma lesão e, por essa razão possuem interesse pessoal na resolução do caso". Assim, há necessidade de demonstração pelo autor de possuir injury o fact (lesão de fato) e personal stake (posição de interesse no resultado do processo) (Cf. SALLES, Carlos Alberto de. "Ações coletivas: premissas para ...", Op. Cit., p. 21). No Brasil, por se negar a legitimidade às pessoas físicas, os legitimados não são membros do grupo lesado, mas apenas verdadeiros porta-vozes desses direitos, de maneira que o requisito do personal stake não guarda relação com o direito brasileiro.
} 
que se trata de legitimação extraordinária por substituição processual ${ }^{114}$, apesar de essa substituição processual não se dar em seu sentido puro antes estudado, pois aqui se trata de substituição de toda uma coletividade ${ }^{115}$. Além disso, faz-se ressalva à peculiaridade do regime da coisa julgada coletiva, cujo objetivo é o de minimizar eventuais prejuízos aos titulares do direito, como será adiante estudado.

No entanto, não é consenso na doutrina que a legitimação nos processos coletivos seja extraordinária por substituição processual ${ }^{116}$. Nesse sentido, Rizzatto Nunes entende ser extraordinária apenas a legitimação para a defesa dos interesses individuais homogêneos, sendo autônoma para a condução do processo aquela protetiva dos coletivos e difusos ${ }^{117}$. Já Rodolfo Mancuso salienta ser a legitimidade das associações ordinária, quando defendem bem difuso ou coletivo cuja proteção está prevista em seus fins institucionais, defendendo, assim, interesse próprio $^{118}$.

Na legislação brasileira atualmente em vigor, em um primeiro momento, pode-se cogitar que a legitimação para os processos coletivos opere ope legis, pois as leis que tratam do tema estabelecem um rol de legitimados para a propositura da ação coletiva, estando elas atualmente concentradas no Código de Defesa do Consumidor e na Lei da Ação Civil Pública ${ }^{119}$. É de se observar que a legitimidade é autônoma e concorrente entre todos os entes, não havendo qualquer relação de predominância ou subordinação entre eles.

\footnotetext{
114 Teori Zavascki recorda, como antes anotado neste capítulo, que a substituição processual significa a defesa em nome próprio de direito alheio. No entanto, no que toca aos direitos individuais homogêneos, que são apenas acidentalmente coletivos, não há relação com o artigo $6^{\circ}$ do Código de Processo Civil, pois a substituição se dá apenas no plano processual (ZAVASCKI, Teori Albino. Processo Coletivo ....., Op. Cit., p. 77).

${ }^{115}$ Pedro Lenza deixa bem evidente essa distinção, ao anotar que se propõe "uma releitura do instituto clássico da legitimação extraordinária, tomada, agora, sob a perspectiva coletiva, no sentido de sempre haver a substituição de uma coletividade, mais ou menos determinada, chegando, muitas vezes, a ser indeterminável, como os titulares da relação jurídica material de bens ou interesses difusos, ligados por circunstâncias de fato" (LENZA, Pedro, Teoria ....., Op. Cit., p. 185).

${ }^{116}$ Defendem se tratar de legitimação extraordinária, além de Pedro Lenza e Teori Zavascki, antes citados, Pedro Dinamarco (DINAMARCO, Pedro da Silva. Ação Civil Pública. São Paulo: Saraiva, 2001, p. 138/140), Diogo Maia (MAIA, Diogo Campos Medina. Ação Coletiva ...., Op. Cit., p. 48/50).

${ }^{117}$ De acordo com autor, isso decorreria da indivisibilidade do objeto material envolvido, porque, como não se poderia determinarem seus titulares, não se poderia afirmar a defesa em nome próprio de um direito alheio. Assim, a legitimação seria autônoma, própria dos processos coletivos (NUNES, Rizzato. Comentários ao Código de Defesa do Consumidor, 4 ed. São Paulo: Saraiva, 2009, p. 767/768).

${ }^{118}$ V. MANCUSO, Rodolfo de Camargo, Ação Civil Pública em defesa do Meio Ambiente, do Patrimônio Cultural e dos Consumidores, $7^{\mathrm{a}}$ ed. São Paulo: RT, 2001, p. 132/135. O autor também ressalta que apenas na hipótese de defesa de direitos individuais homogêneos se estaria diante de legitimação extraordinária, porque, só então, haveria pretensão de tutela de interesse alheio.

${ }_{119}$ Consoante observa Fernando Dusi Rocha, "o problema da legitimidade mostra que não nos livramos do formalismo processual, da concepção formal do Direito, vista por Norberto Bobbio como Direito de acordo
} 
Assim, dispõe o artigo 82 do diploma consumeirista serem legitimados concorrentes para a propositura de ações voltadas à defesa dos interesses especificados naquela lei, o Ministério Público, as Fazendas Públicas, os órgãos da administração pública direta e indireta e as associações constituídas há pelo menos um ano que incluam dentre seus objetivos sociais a proteção dessa sorte de direitos. Além desses, o artigo $5^{\circ}$ da Lei da Ação Civil Pública, modificado pela Lei n. 11.448/07, confere legitimidade à Defensoria Pública, e a Constituição Federal aos sindicatos para a defesa dos interesses da categoria (artigo $8^{\circ}$, III) e aos partidos políticos para a propositura de ação direta de inconstitucionalidade (artigo 103, VIII). E é ainda de se mencionar a legitimidade de qualquer cidadão para a promoção de ação popular (Lei n. 4.717/65).

As leis atualmente em vigor não fazem nenhuma ressalva das espécies de direitos que cada um dos legitimados pode tutelar, exigindo apenas das associações, como se ressaltou no capítulo anterior, a pré-constituição de um ano e a inclusão, dentre seus fins institucionais, da defesa dos direitos que objetiva tutelar. Além desse requisito, que será aprofundado quando do estudo específico da legitimidade das associações, nada mais se exige, razão pela qual por muito tempo perdurou o entendimento de que bastava ser um dos legitimados especificados pela lei para a propositura de qualquer ação coletiva, ainda que não existisse nenhuma pertinência temática entre o legitimado e o direito protegido.

O Projeto de Lei n. 5.139/09, enviado ao Congresso para unificar o regramento legislativo dos processos coletivos, em linhas gerais, manteve as disposições já existentes, tendo apenas incluído dentre eles a Ordem dos Advogados do Brasil, cujo Conselho Federal já é autorizado a promover ação direta de inconstitucionalidade (artigo 103, VII, da Carta Magna). O Projeto também não incluiu a pessoa física dentre os legitimados ${ }^{120}$.

com sua estrutura formal (juspositivista)" (ROCHA, Fernando Antonio Dusi. Ampliação da legitimidade, superando-se a individualidade restrita: ampliação das hipóteses de ações coletivas. Revista CEJ, Brasília, v. 5 , n. 13 , jan-abr/2001, p. 54).

${ }^{120} \mathrm{O}$ Anteprojeto elaborado pelos estudiosos do tema, que deu origem ao Projeto ora em tramitação no Congresso Nacional, ampliava o rol de legitimados. Entre eles, de acordo com seu artigo 20, incluía-se a pessoa física e o membro do grupo (atrelando-se a atuação desses ao reconhecimento da representatividade adequada), o que também está previsto no código Modelo de Processos Coletivos para Ibero-América. Essa previsão aproximava o processo coletivo brasileiro das class actions norte-americanas, pois, naquele ordenamento, a defesa dos direitos coletivos é conferida, principalmente, ao membro do grupo. Além disso, 
A diferença de tratamento no Projeto, que segue a orientação do contido no artigo $3^{\circ}$ do Código Modelo para Ibero-América, foi a inclusão de alguns requisitos a alguns outros legitimados, que não só a associação, voltados à verificação da pertinência temática desses com o objeto que se pretende levar ao Judiciário, o que, de certa forma, já é aplicado pelos Tribunais brasileiros. Todavia, não tratou o Projeto, expressamente, da necessidade de observância da representatividade adequada, até porque esse instituto não foi relacionado dentre os princípios da ação coletiva. A inserção dessa exigência imporia uma análise mais ampla - e voltada à maior eficácia na defesa dos direitos - do que uma simples correlação com o objeto de atuação do ente legitimado, pois ela ultrapassa essa verificação, como se viu no capítulo anterior.

No entanto, mesmo diante da lei posta, o entendimento de que a norma teria sido exauriente ao definir quem seriam os legitimados nas ações coletivas, sendo bastante para sua averiguação o simples exame do texto legal, não se mostra de rigor. Com base nesse entendimento, ficaria alijado dos poderes do magistrado o controle, no caso concreto, da representatividade adequada. Tal controle, de acordo com esse entendimento, teria sido exercido previamente pelo legislador quando da atribuição da legitimação coletiva, não sendo permitido ao magistrado questionar o representante a quem a lei atribuiu legitimação.

Assim, fazendo-se valer da tradição americana no tratamento das class actions, admite-se a possibilidade do controle judicial da representatividade adequada (ope iudicis), mesmo já diante da lei posta, pois o que se tem na lei é uma mera presunção de adequação, mas essa não é absoluta ${ }^{121}$. O controle judicial da representatividade adequada

inúmeras outras vantagens há de se conferir legitimação à pessoa física, conforme será estudado adiante em tópico específico sobre o tema.

${ }^{121}$ V., nesse sentido, GRINOVER, Ada Pellegrini. Ações coletivas ibero-americanas: novas questões sobre a legitimação e a coisa julgada. Revista Forense. Rio de Janeiro: Forense, 2002, n. 361, p. 6.

De acordo com o posicionamento, José Marcelo Vigliar afirma haver no Brasil um sistema "misto"de aferição da legitimidade, pois "partimos de um rol de legitimados apresentados pelo legislador, mas o Judiciário faz sim (e deve mesmo realizá-lo) o controle da representação adequada". Segundo o autor, que foi membro do Ministério Público, isso resta bastante claro quanto à fiscalização da atuação desse ente. (VIGLIAR, José Marcelo de Menezes, "Defendant class action brasileira ...", Op. Cit., p. 315). Em que pese não acreditemos que ele já seja efetivamente exercido em relação ao ente ministerial, como adiante se verá, do dever afirmado pelo autor não podemos discordar.

No mesmo sentido, Elton Venturi, ao comentar o artigo $3^{\circ}$ do Código Modelo, revela a necessidade de se aferir a representatividade adequada. Anota o autor que "tais legitimados, ao serem elencados como possíveis propulsores das ações coletivas, já contam com uma presunção relativa ex lege de adequada 
reside, fundamentalmente, na análise do liame existente entre o representante legitimado e objeto litigioso, uma verdadeira análise da adequação dessa representação, em grau mais aprofundado do que uma mera verificação da pertinência temática, como prevê agora o Projeto.

O sistema de aferição judicial da legitimidade, em termos de eficácia na proteção dos direitos, supera em muito o sistema de aferição legal. Isso porque permite ao magistrado analisar a figura daquele que vem a juízo como legitimado diante do caso concreto, não se limitando a averiguação de interesse (entendido como relação com o objeto), mas da própria credibilidade e seriedade do ente e da postura dele diante de outras situações violadoras do mesmo objeto, circunstância que torna possível verificar também se não há mera hipótese de promoção pessoal do legitimado ou de quaisquer de seus membros.

A possibilidade de atuação judicial nesse campo não reside somente na aferição da legitimidade das associações, em que a lei dá brecha expressa para tanto, mas também em relação a todos os outros legitimados e existiria com especial relevância se fosse autorizada a promoção de ações pela pessoa física, ponto a que ainda não chegamos nas sucessivas alterações legislativas.

Desse modo, para o prosseguimento deste trabalho, essencial se faz analisar dois dos principais legitimados - o Ministério Público e as associações - bem como o mais importante possível legitimado - a pessoa física - para verificar como pode ser aplicado ou como poderia ser aplicado, se não já possível, o princípio da representatividade adequada em relação a eles.

\subsubsection{O Ministério Público como legitimado}

Atualmente, a grande maioria das ações coletivas é promovida, no Brasil, pelo Ministério Público. Essa situação, em que pese o crescimento da atuação

representatividade, presunção essa que necessita ser complementada, como visto antes, com a demonstração concreta de idoneidade técnica, financeira, social e política para a condução da demanda coletiva" (VENTURI, Elton. Comentários ao Código Modelo de Processos Coletivos. Um diálogo Ibero-Americano. Salvador: Editora Juspodivm, 2009, p. 71). Assim, como claro está na posição do autor, a legitimidade conferida pela lei não se mostra suficiente para a aceitação do ente na demanda. 
específica do órgão ministerial e a competência, via de regra, do trabalho por ele desenvolvido, não é de se aplaudir, pois o ideal seria que a própria sociedade se organizasse, por meio de associações civis, para a defesa dos direitos que lhe tocam ${ }^{122}$.

Não se pode olvidar que muitos dos direitos coletivos defendidos por meio dessas ações o são em face do Estado, sendo, no mínimo, estranho que um próprio órgão do Estado seja o principal defensor deles, ainda que ele seja dotado de independência funcional e de autonomia. Assim, o ente estatal não pode ser, em concreto, quase que o único defensor dos direitos tutelados, havendo de se impor um meio, à sociedade, para que aja na persecução de seus direitos, pois não faz sentido os cidadãos exigirem participação e questionarem a atuação dos governantes, se não utilizam os meios de que dispõem para tanto ${ }^{123}$.

Em relação ao direito norte-americano, Owen Fiss relata que os Estados Unidos sempre se afastaram da legitimação do equivalente ao Ministério Público naquele país, justamente para não deixar tudo na mão dos órgãos governamentais. Possuem lá os cidadãos grandes preocupações com o sistema oficial de governança e com eventual abuso de discricionariedade, pelo que preferiram deixar a legitimidade para as ações coletivas

\footnotetext{
${ }^{122}$ Luis Roberto Proença ressalta dever ser a atuação do Ministério Público ainda mais premente nessa área, para o que aponta soluções específicas, em vista da "ainda incipiente organização das entidades não governamentais em nossa sociedade" e da dificuldade, por razões políticas, dos demais legitimados terem uma atuação mais firme na defesa dos direitos de natureza coletiva. (PROENÇA, Luis Roberto. Inquérito Civil - Atuação investigativa do Ministério Público a serviço da ampliação do acesso à Justiça. São Paulo: Revista dos Tribunais, 2001, p. 141/177, especialmente p. 142). Todavia, cremos que a solução seja exatamente a inversa, pois, se conferidos ainda maiores poderes ao ente ministerial, essa herança histórica nunca irá se desfazer.

${ }^{123}$ Pondera Mirra que as "peculiaridades dos direitos e interesses difusos põem à mostra o significado político da sua proteção, na medida em que, apesar de serem direitos e interesses supra-individuais e indisponíveis, não têm e não podem ter no Estado o titular único e exclusivo da persecução da sua satisfação, impondo-se a abertura de canais para a participação democrática dos indivíduos e dos diversos grupos sociais em sua tutela" (MIRRA, Álvaro Luiz Valery, “Associações civis e a defesa ...”, Op. Cit., p. 115).

Luís Roberto Proença vê, nesse fato, um entrave à atuação do Ministério Público, pelo que faz propostas no sentido de aumentar a autonomia do órgão em face do Estado. De acordo com o autor "a área de conflituosidade com o poder político, assim, é extensa, tornando-se mais sensível no caso do Executivo, que é quem detém a possibilidade de dificultar a atuação do Ministério Público, através da articulação com sua usual maioria parlamentar e do contingenciamento das dotações orçamentárias. Daí a necessidade de melhor equacionar, dentro dos parâmetros democráticos, a autonomia administrativa do Parquet" (PROENÇA, Luis Roberto. Inquérito Civil - Atuação ..., Op. Cit., p. 143/146). Todavia, a nosso ver, melhor solução seria desvincular ao máximo a atuação desse ente em relação a direitos coletivos pretendidos em face do Estado, justamente para evitar essa dicotomia, ao invés de se tentar desatrelar aquele órgão da Administração Pública direta.
} 
com os particulares. Certamente esse fato, oriundo da maior politização dos cidadãos, foi preponderante para a própria maior organização social dos indivíduos ${ }^{124}$

Dessa forma, ideal em relação aos processos coletivos seria que esse ente estatal atuasse como mero fiscal da lei ou com legitimidade subsidiária, na hipótese, por exemplo, de abandono da causa por outro legitimado. Tal situação, no entanto, só seria possível se a sociedade se organizasse para fazer efetivos os seus direitos. Como não existe essa cultura na sociedade brasileira, não se poderia propor alteração legislativa no sentido de suprimir a legitimação do Ministério Público, porque isso significaria assassinar os processos coletivos, minando qualquer tentativa de evolução. Contudo, seria imperioso criarem-se mecanismos de atuação conjunta desse órgão com os entes sociais, de modo que, ao invés de eles limitarem-se a dar notícias de violação de direitos ao Ministério Público, atuassem positivamente e em juízo em busca dos direitos do grupo ${ }^{125}$. Antes disso, no entanto, é preciso uma substancial mudança de consciência individual, para que se atinja a necessária consciência de classe ${ }^{126}$.

Desse modo, no presente momento, a manutenção da legitimidade do Ministério Público para os processos coletivos é essencial. Contudo, ela não pode ser indiscriminada, impondo-se um controle material específico de sua atuação pelos magistrados, pois nem sempre o que esse órgão busca tutelar reflete a vontade da sociedade e não se pode menosprezar a ideia de que este órgão é, antes de tudo, um representante da sociedade. Nessa análise, é possível, mesmo diante de previsão da lei posta, aplicar o instituto da representatividade adequada, fazendo-o em face do âmbito de atuação do órgão ministerial, previsto no artigo 127 da Constituição Federal, que estabelece que a esse ente incumbe "a defesa da ordem jurídica, do regime democrático e dos interesses sociais e individuais indisponíveis".

\footnotetext{
${ }^{124}$ V. FISS, Owen. Um novo Processo ...., Op. Cit., p. 235/236

125 O Professor espanhol Pablo de Cabiedes analisa justamente esse aspecto, pois ressalta que a atuação do Ministério Público não é muito diferente da atuação que pode ter uma associação na defesa dos direitos supraindividuais. "Su propia función representativa, así como la información y publicidad previa que del proceso se da soporte a esa actuación representativa y permite a los afectados ejercer ellos mismos su propia defensa u otorgarla a otro ente" (CABIEDES, Pablo Gutiérrez de. "Comentario al art. 3 ", in Comentários ao Código Modelo de Processos Coletivos. Um diálogo Ibero-Americano. Salvador: Editora Juspodivm, 2009, p. 87).

${ }^{126}$ Nesse ponto, importante observar que a consciência de classe é um dos mais importantes requisitos para o sucesso dos processos coletivos numa sociedade. De acordo com Diogo Maia, esse tipo de processo só teve um desenvolvimento mais profícuo a partir da Revolução Industrial, no século XIX, quando se adquiriu a consciência do que era o grupo, mediante a organização dos trabalhadores (V. MAIA, Diogo Campos Medina. Ação Coletiva ...., Op. Cit., p. 11/19).
} 
É certo que a representatividade adequada não será aqui analisada quanto à credibilidade ou à capacidade do ente ministerial, pois essas são presumidas, diante da própria estrutura e do sistema de ingresso na carreira. A adequação da representação deverá atender aos critérios de coincidência de interesses da sociedade, ou seja, da representatividade do Ministério Público, na questão específica, em relação à sociedade. Se ela não existir, não se pode afirmar haver a necessária defesa dos interesses sociais.

Diante disso, é errôneo o entendimento de que a legitimação do Ministério Público é irrestrita e absoluta, em relação a qualquer direito coletivo em sentido lato submetido ao Judiciário, pois imperiosa se faz a demonstração de que se trata de interesses indisponíveis ou socialmente relevantes ${ }^{127}$. Não se pode concordar com o entendimento, esposado por Nelson Nery, de que existe interesse social evidente no simples ajuizamento de ações coletivas, pelo fato de se referir a interesses de toda a sociedade, solucionados por meio de apenas uma demanda, sendo o interesse um pressuposto porque se conferiu a legitimação ${ }^{128}$. Ao contrário, é imprescindível que o objeto material a ser tutelado reflita propriamente esse interesse.

Relativamente aos interesses difusos, a configuração desse requisito é mais simples, pois esses são direitos indisponíveis, pertencentes a toda a sociedade e, por isso, via de regra, socialmente relevantes, de modo que a legitimidade do Ministério Público resta mais evidente. Mesmo assim, como salienta o Professor Mancuso, ao tratar da ação civil pública, a legitimidade do ente ministerial não é absoluta e presumida, mas

\footnotetext{
${ }^{127}$ Interessante ressaltar que, se a atuação do Ministério Público pressupõe a relevância social ou a indisponibilidade dos direitos, qualquer ação coletiva que tenha expressamente reconhecida sua legitimidade terá garantida a sua admissão para análise pelo Supremo Tribunal Federal. Essa externalidade advém da nova sistemática da admissão dos recursos extraordinários, prevista no artigo 543-A do Código de Processo Civil. De acordo com o estabelecido nessa norma, o Supremo Tribunal Federal só conhecerá de recursos com repercussão geral, o que significa, segundo o $\S 1^{\circ}$ da norma, a "existência, ou não, de questões relevantes do ponto de vista econômico, político, social ou jurídico, que ultrapassem os interesses subjetivos da causa". Assim, numa demanda promovida pelo ente ministerial, o recurso extraordinário, ainda que do requerido, não pode ser rejeitado sob esse fundamento, porque isso corresponderia a afirmar a ilegitimidade do órgão.

${ }^{128}$ V. NERY JÚNIOR, Nelson. "O Ministério Público e as Ações Coletivas", in MILARÉ, Edis (coord.). Ação Civil Pública (Lei 7.347/85 - Reminiscências e Reflexões após dez anos de aplicação). São Paulo: Revista dos Tribunais, 1995, p. 358/366.
} 
deve ser feita confrontando o objeto passível de tutela com o interesse do órgão, o que se pode concluir ser a própria análise da representatividade adequada ${ }^{129}$.

Contudo, no que toca aos direitos coletivos e individuais homogêneos, a situação não é tão simples do ponto de vista prático, fazendo-se necessária a análise concreta do que se traz a juízo, para verificar se existe a indisponibilidade e o interesse social, para o que, sem dúvida, deve entrar em jogo a análise da adequação da representação pelo magistrado.

No entanto, não há consenso na doutrina sobre a possibilidade da realização dessa valoração da legitimidade em face do objeto do processo pelo magistrado, pois há quem entenda, como afirma Mirra, que a identificação da relevância social deve ser feita pelo próprio Ministério Público, cabendo ao juiz apenas uma análise "ponderada e discreta", diante da afirmação do ente ministerial ${ }^{130}$. Todavia, nossa posição é distinta, pois se acredita que, em face do disposto no artigo 127 da Constituição Federal, essa análise já é permitida de ser realizada pelo magistrado, a par do entendimento ministerial, o que equivale à verificação da representatividade adequada, que é princípio geral das ações coletivas $^{131}$.

\footnotetext{
${ }^{129}$ O Professor traz elucidativa consideração, anotando que, "admitindo-se, gratia argumentandi, que o dominus litis fosse o Ministério Público, cremos que ainda assim não se poderia daí extrair a conclusão de que o interesse de agir ficaria 'presumido' ou decorrente ipso facto da exclusividade da legitimação. Isso porque o interesse de agir é de natureza estritamente processual, inconfundível com o interesse substancial, material (embora a este seja tangencial, enquanto instrumento). E, no que concerne à legitimação, há várias hipóteses em que, como diz Donaldo Armelin, 'presente a legitimidade, o interesse não se corporifica', exemplificando... (MANCUSO, Rodolfo de Camargo. Ação Civil Pública em ..., Op. Cit., p. 55).

${ }^{130}$ Para o autor, a possibilidade de análise inexiste na lei posta, sendo meramente prevista no direito projetado (MIRRA, Álvaro Luiz Valery, "A legitimidade ativa do Ministério Público para a defesa dos direitos individuais homogêneos", in SALLES, Carlos Alberto de, SILVA, S. T.., NUSDEO, Ana Maria de Oliveira. Processos coletivos e tutela ambiental. Santos: EDUL - Editora Universitária Leopoldiaum, 2006, p. 54/56).

Esse também é o entender de Luís Roberto Proença, pois o autor defende a adoção do princípio da oportunidade, ao invés do da indisponibilidade, na atuação do órgão na defesa de direitos coletivos em sentido lato (PROENÇA, Luis Roberto. Inquérito Civil - Atuação ..., Op. Cit., p. 156/163).

${ }^{131}$ Também de acordo com a fiscalização da adequação da representatividade do Ministério Público se posiciona Jordão Violin (VIOLIN, Jordão. Ação Coletiva Passiva..., Op. Cit., p. 73/74).

Anote-se, nesse sentido, que o Anteprojeto, ao tratar da legitimidade do órgão ministerial, estabelecia que ela ocorreria para defesa dos interesses individuais homogêneos de interesse social (artigo 20, III), especificando que deve haver demonstração desse interesse pelo legitimado ( $\left(1^{\circ}\right.$ do mesmo artigo 20 ), em relação a que estaria a oportunidade da aferição da representatividade adequada. Todavia, essa disposição não consta do Projeto enviado ao Congresso, haja vista esse não fazer nenhuma ressalva para a legitimação do Ministério Público, o que só prejudica o desenvolvimento dos processos coletivos, pois serão mantidos os mesmos questionamentos, que, inclusive, atrasam o próprio processamento das ações coletivas.
} 
Alguma discussão sobre o assunto já existe nos Tribunais brasileiros, sempre em face da função desse órgão estatal, o que se pode afirmar ser uma análise da adequação da representatividade adequada, ainda que assim não a classifiquem os Tribunais.

A título meramente exemplificativo, o Supremo Tribunal Federal já reconheceu a legitimidade do Ministério Público para a promoção de ação coletiva para impelir o Estado a fornecer medicamentos a pessoas portadoras de doenças ${ }^{132}$; para impedir o aumento abusivo de mensalidades escolares ${ }^{133}$; para assegurar o direito de obtenção de certidões ${ }^{134}$. Em todas essas situações há, sem dúvida, interesses indisponíveis ou socialmente relevantes, que permitem a atuação desse órgão. Todavia, nas duas primeiras hipóteses, a mesma defesa poderia ser realizada pela associação dos portadores da doença e pelas associação de pais e responsáveis pelos alunos, atuação que seria mais vantajosa tanto para o Estado quanto para os envolvidos.

No entanto, a mesma legitimidade é reconhecida para defesa de consumidores lesados em consórcio formalizado por meio de contrato de adesão. Nesse caso, em que pese o entendimento do Supremo Tribunal Federal ${ }^{135}$, entendemos não estar presente o requisito da indisponibilidade ou da relevância social, que conferiria legitimidade ao órgão. A análise deu-se de acordo com o critério ope legis, tendo ela sido afirmada somente por se tratar de relação de consumo. Mas ela fere o artigo 127 da Constituição Federal, pois nem toda relação dessa ordem trata de interesses indisponíveis ou socialmente relevantes ${ }^{136}$.

Interessante observar que um dos objetos mais defendidos pelo Ministério Público nas ações por ele promovidas é o patrimônio público, um direito indisponível e socialmente relevante. O Supremo Tribunal Federal, em diversos julgamentos, já reconheceu legitimidade do ente para tanto ${ }^{137}$, mas entendemos seja esse reconhecimento equivocado, pois tal direito, apesar do caráter social, não é coletivo, mas

\footnotetext{
${ }^{132}$ RE 407902, Relator Min. MARCO AURÉLIO, Primeira Turma, j. 6/05/2009.

133 AI 722896 AgR, Relatora Min. CARMEN LÚCIA, Primeira Turma, j. 23/06/2009.

${ }^{134}$ RE 472489 AgR, Relator Min. CELSO DE MELLO, Segunda Turma, j. 29/04/2008.

${ }^{135}$ AI 618240 AgR, Relator Min. GILMAR MENDES, Segunda Turma, j. 01/04/2008.

136 V., nesse sentido, entendimento de ZAVASCKI, Teori Albino. Processo Coletivo ....., Op. Cit., p. 240/242).

${ }^{137}$ Cf. RE 163231, Relator Ministro MAURÍCIO CORRÊA, Pleno, j. 29/09/01.
} 
próprio da Fazenda Pública lesada, sendo vedado ao ente ministerial representar qualquer entidade pública em juízo, por força do disposto no artigo 129, IX, da Constituição Federal. Como bem anota Teori Zavascki, ao tratar do interesse social, esse é o interesse público, que é diferente do particular e do interesse da Administração Pública, que é interno do ente estatal ${ }^{138}$.

Também é conveniente mencionar que, muitas vezes, o suposto interesse coletivo defendido pelo Ministério Público pode contrapor-se a outro interesse coletivo socialmente relevante, não se justificando a posição adotada pelo órgão ministerial favorável a um em detrimento do outro. Situação exemplificativa disso é a atuação do órgão no Município de São Paulo, quando da proibição dos ônibus fretados no centro urbano. Nesse caso, há diversos direitos coletivos em sentido lato envolvidos: o direito ao transporte de milhares de cidadãos, o direito à exploração do ramo de transportes por empresas de ônibus e o direito comum a todos de um meio ambiente urbano digno. Esse último, por ser indisponível e de caráter relevante, permite a atuação do Ministério Público, mas é de se questionar que aspecto deveria defender o órgão, já que a própria sociedade não decidiu se o meio ambiente urbano ficaria melhor com os ônibus, restringindo a circulação de milhares de carros e oferecendo às pessoas meios coletivos de transporte, ou sem os ônibus, auxiliando na diminuição da poluição atmosférica; há verdadeiro conflito de interesses sociais relativamente a nesse ponto. Assim, sem se pretender trazer uma solução para o caso, qualquer posição defendida pelo ente ministerial poderia ser questionada, haja vista que nenhuma delas seria efetivamente representativa da sociedade, mas somente da pessoa física investida no cargo, de forma que talvez o órgão devesse restar distante da questão, que pode muito bem ser resolvida entre os sindicatos e associações representantes das categorias.

Não se pode olvidar, outrossim, que a própria atuação do Ministério Público é alvo de controvérsia doutrinária, pois as mesmas restrições passíveis de serem feitas a qualquer outro legitimado podem também recair sobre o representante do Ministério Público. Há possibilidade, como bem recorda o Professor Kazuo Watanabe ${ }^{139}$, de se pretender a projeção social individual do representante da instituição ou mesmo dela

${ }^{138} \mathrm{O}$ autor defende que é possível a tutela pelo Ministério Público do patrimônio público apenas em situações especiais, em que o interesse é superior e transcende o interesse ordinário da pessoa titular do interesse lesado (ZAVASCKI, Teori Albino. Processo Coletivo ....., Op. Cit., p. 51/55 e 157).

${ }^{139}$ WATANABE, Kazuo, “Disposições gerais"...., Op.Cit., p. 734/736. 
própria, em detrimento da efetiva tutela dos direitos coletivos ou indisponíveis. Essa situação, que infelizmente tem sido noticiada, não só em relação ao ente ministerial como ao próprio Judiciário, obviamente que não de maneira generalizada, indica, de qualquer modo, que não é despiciendo o controle da representatividade desse órgão.

Desse modo, verifica-se, já de acordo com a atual lei em vigor, que o controle judicial da representação adequada pelo Ministério Público é possível, viável, permitido e, mais do que isso, necessário para o bom desenvolvimento dos processos coletivos.

\subsubsection{As associações civis}

Outro legitimado que deve ser analisado neste estudo são as associações civis, legalmente constituídas, a teor do inciso IV, do artigo 82 do Código de Defesa do Consumidor, "há pelo menos um ano e que incluam entre seus fins institucionais a defesa dos interesses e direitos protegidos por este Código, dispensada a autorização assemblear”. A lei ainda prossegue, no $\S 1^{\circ}$ de referido artigo, salientando que o requisito da préconstituição pode ser dispensado pelo magistrado nas ações de reparação de dano, quando "haja manifesto interesse social evidenciado pela dimensão ou característica do dano, ou pela relevância do bem jurídico a ser protegido”.

As associações são a forma mais importante de defesa dos direitos coletivos. Isso porque são a própria expressão da sociedade, haja vista serem entes criados espontaneamente por seus cidadãos, para a defesa de direitos que lhes interessam, fazendose valer as garantias constitucionais de participação e de organização. Ou seja, são os entes intermediários entre os cidadãos e o Poder Público, criados justamente para que aqueles tenham mais força em suas reivindicações perante esses. Assim, as associações são uma das facetas mais relevantes do Estado Democrático de Direito, por meio das quais os direitos de massa são tutelados pelos organismos constituídos por essa própria massa ${ }^{140}$.

\footnotetext{
140 Nas palavras de Elton Venturi, "as associações civis são as entidades naturalmente vocacionadas à promoção da tutela coletiva na medida em que nascem em decorrência do surgimento de interesses transindividuais ou individuais homogêneos provenientes de determinados grupos sociais. (...) Podem ser consideradas entidades catalisadoras dos interesses difusos e individuais homogêneos, na medida em que potencialmente concentram em torno de si expressivo contingente de indivíduos, formalmente a elas ligados, e encontram sua finalidade existencial na própria defesa de direitos individuais, coletivos e difusos que se
} 
Nas class actions norte-americanas, não há previsão da legitimidade das associações, em vista do requisito de o autor coletivo, para a defesa de interesses individuais homogêneos, ser membro do grupo. Todavia, como anota Gidi, apesar de negada por muitos, a legitimação não pode ser afastada, em vista da legitimidade representacional do grupo por esses entes intermediários, que poderiam, pois, agir em juízo de acordo com o ordenamento vigente naquele país ${ }^{141}$.

Infelizmente, o papel da maioria das associações no Brasil não tem sido tão efetivo. A maior parte delas, salvo raríssimas exceções de entes mais organizados, limita-se a levar problemas ao Ministério Público, para que esse busque, na via judicial ou administrativa, a defesa dos interesses coletivos. Todavia, o ideal seria que as próprias entidades civis tentassem solucionar esses problemas, buscando junto aos infratores dos direitos ou ao Judiciário, a defesa de seus interesses. Somente por meio de sua efetiva atuação será possível que exerçam a necessária ligação - que é sua verdadeira função entre os cidadãos e as entidades violadoras dos direitos, sejam estas pertencentes ao Poder Público ou não, atuando como uma longa manus da sociedade. No entanto, existe uma grande deficiência quantitativa e qualitativa na atuação dessas entidades civis no Brasil, ocasionada tanto pela falta de cultura de organização, como pelos próprios órgãos políticos que não incentivam a criação desses entes pela sociedade ${ }^{142}$.

relacionem com seus fins estatutários (VENTURI, Elton. "Comentário ao art. $3^{\mathrm{o}}$, in Comentários ao Código ..., Op. Cit., p. 74/75).

${ }^{141}$ V. GIDI, Antonio. A Class Action como instrumento ...., Op. Cit., p. 126/128.

${ }^{142}$ Pedro Dinamarco realizou um levantamento bastante extenso sobre a atuação das associações em diversos países de civil law. Interessante trazer a este estudo o que anotou em relação as associações em Portugal, país em que se verifica uma efetiva atuação desses entes intermediários. De acordo com o estudo feito pelo autor, naquele país, elas podem participar e intervir na definição política e nas grandes linhas de orientação legislativa no que se refere ao meio-ambiente e aos direitos dos consumidores. Além disso, as associações podem até mesmo figurar como parte acusadora em processo criminal em alguns casos, o que revela a importância que aquele país confere a esses entes tão relevantes na estrutura social (V. DINAMARCO, Pedro da Silva. Ação Civil ..., Op. Cit., p. 140/149, especialmente, em relação a Portugal, p. 143).

Angelo de Santis relata que os processos coletivos no ordenamento italiano, especialmente os relativos a direitos do consumidor, que são o foco maior naquele país, só passaram a ter maior relevância nacional a partir do fortalecimento das associações. Segundo o autor italiano, "innegabile è poi la crescente capacità di influenza esercitata dalle associazoni dei consumatori che, unita ad una maggiore presa di coscienza dei propri diritti da parte di questi ultimi, ha condotto al positivo riconoscimento, in favore delle stesse associazioni, della legitimazione ad agire in giudizio al fine di tutelare diritti dei consumatori e degli utenti" (DE SANTIS, Angelo Danilo. "I disegni di legge italiani ....", Op. Cit., p. 603). 
De qualquer modo, como antes se disse, apesar da deficiência concreta que se tem hoje na atuação das associações, a legitimidade atribuída a elas é uma forma eficaz de conferir à sociedade a possibilidade de manifestação e de defesa de seus direitos.

De acordo com o especificado pela legislação brasileira atualmente em vigor, as associações necessitam observar três requisitos para estarem em juízo: constituição legal, isto é, terem seus estatutos registrados nos órgãos competentes e serem dotadas de personalidade jurídica; constituição há pelo menos um ano e constância dentre suas finalidades dos direitos protegidos. São apenas esses requisitos legais, não tendo sido aprovada a previsão, originalmente constante do Projeto Bierrenbach (Projeto n. 3.034/84), que deu origem à atual Lei da Ação Civil Pública, da necessidade de o juiz verificar em cada caso concreto a representatividade adequada das associações civis, exercendo juízo discricionário para tanto. Dessa forma, a lei posta estabelece apenas critérios objetivos, para cuja verificação é desnecessário qualquer controle judicial.

O Projeto de Lei n. 5.139/09 manteve, em seu artigo $6^{\circ}$, que trata da legitimação, os mesmos requisitos para a legitimação das associações, que também são vistos no Código Modelo de Processos Coletivos para Ibero-América. A única distinção é que não afirma deverem as associações estar constituídas há pelo menos um ano, mas, sim, "associações legalmente constituídas e em funcionamento há pelo menos um ano". Essa distinção aparentemente superficial não o é, pois deve ser interpretada como desnecessidade da constituição legal no período, bastando estar em funcionamento, abrindo espaço para associações de fato - que depois se constituam legalmente - agirem em juízo. Muitas vezes, os integrantes de uma associação não veem de imediato a necessidade de sua constituição legal, pois os simples agrupamento e organização parecem suficientes para os fins para os quais foi criada. Poderão só atentar para essa necessidade diante de um problema concreto, às vezes após muitos anos de existência fática, de maneira que não seria lícito impedir esses entes de agirem em juízo.

O Professor Rodolfo Mancuso já ressaltou ser uma tendência conferir-se legitimação aos grupos sociais de fato, não personificados, ressaltando que a própria natureza dos fatos conduz a uma legitimação difusa, no entanto, entende que sendo os interesses envolvidos sujeitos a uma rápida transformação, seria excesso de formalismo exigir a constituição desses entes para atuar em juízo. Todavia, não se pode olvidar, como 
também alerta o autor, que o Estado, à medida que confere a esses entes a figura de colaboradores na gestão do bem comum, deve exigir certas cautelas, para prova de sua idoneidade. No entanto, como agora dispõe o Projeto da necessidade de prova do funcionamento e de outros requisitos para que a associação possa estar em juízo, é certo que essa cautela resta suprida, até porque não se poderia deixar "uma larga margem do fenômeno coletivo (...) desprovida de tutela" ${ }^{143}$.

De qualquer modo, em vista dos requisitos estabelecidos pela lei posta, há expressiva corrente doutrinária que entende ser necessário apenas o preenchimento deles, não sendo possível ao magistrado exigir nada mais do que isso ${ }^{144}$.

Contudo, a Professora Ada Pellegrini Grinover, em trabalho referendado por Kazuo Watanabe, ressaltou os problemas práticos que têm surgido, em vista da presença em juízo de associações que, embora atendam aos critérios da lei, não apresentam os requisitos específicos do representante adequado, como credibilidade, idoneidade, seriedade, capacidade econômica, conhecimento dos interesses que se objetiva sejam defendidos. Nesses casos, de acordo com a Professora, dar possibilidade ao juiz de analisar a legitimidade em relação ao caso concreto é fundamental, para garantir que os direitos sejam eficazmente defendidos em juízo. E, por fim, conclui a autora que "o sistema brasileiro, embora não o afirme expressamente, não é avesso ao controle da 'representatividade adequada' pelo juiz em cada caso concreto" ${ }^{145}$, com o que não se pode deixar de concordar.

A primeira abertura para que tal se faça possível é o constante do $\S 1^{\circ}$, do artigo 82, do Código de Defesa do Consumidor, que estabelece a possibilidade de o juiz

\footnotetext{
${ }^{143}$ V. MANCUSO, Rodolfo de Camargo. Ação Civil Pública em ..., p. 138/140.

${ }^{144}$ Nesse sentido, Álvaro Mirra destaca que esses "requisitos, além de necessários, são suficientes para a caracterização da representatividade adequada da associação civil", anotando que outros requisitos, comuns na disciplina da matéria em ordenamentos jurídicos estrangeiros "não foram contemplados pelo legislador brasileiro como condição para a verificação da representatividade das associações, de modo que não podem ser exigidos, nem mesmo pelo juiz da causa" (MIRRA, Álvaro Luiz Valery, “Ação Civil Pública em Defesa do Meio Ambiente: a representatividade adequada dos entes intermediários legitimados para a causa", in MILARÉ, Edis (coord.). A Ação Civil Pública após 20 anos: efetividade e desafios. São Paulo: Revista dos Tribunais, 2005, p. 46/47). No mesmo sentido, SCARPINELLA BUENO, Cássio. "As class actions norteamericanas e ...", Op. Cit., p. 129.

Ao analisar a legitimidade das associações, Teori Zavascki anota também apenas a necessidade de pertinência material entre os interesses objetos de tutela e os fins institucionais do ente (ZAVASCKI, Teori Albino. Processo Coletivo ....., Op. Cit., p. 198.).

145 GRINOVER, Ada Pellegrini, Ações coletivas ibero-americanas..., Op. Cit., p. 3/12, citada por WATANABE, Kazuo, "Disposições gerais”...., Op.Cit., p. 824/826.
} 
dispensar o requisito de pré-constituição de um ano, quando haja manifesto interesse social evidenciado pela dimensão ou característica do dano, ou pela relevância do bem a ser protegido. De acordo com Rizzato Nunes, essa dispensa teria sido criada e deve ser utilizada para que vítimas de acidentes graves, como de aviões, por exemplo, possam buscar desde logo seus direitos, fazendo-se porta-voz delas uma associação; neste caso, não se justificaria esperar um ano para que ela pudesse atuar ${ }^{146}$. Certamente, essa finalidade é válida - e deve mesmo ser utilizada - e talvez tenha sido esse o espírito da criação da norma, mas ela não pode ser interpretada somente até esse ponto, sendo imperioso estender-se a hipótese para casos além de danos, como a lei permite, ao remeter a avaliação à relevância do bem.

Desse modo, a disposição legal confere verdadeira possibilidade de análise da adequação da representação da associação pelo juiz, pois a lei deixa brecha para um exercício de poder discricionário pelo magistrado, podendo ele, se demonstrada a idoneidade da associação, afastar a necessidade de presença desse requisito temporal limitador, como também, a contrario sensu, negar a legitimidade de uma outra associação, se verificar a inexistência da mesma idoneidade. A pré-constituição em um ano serve, tão só, para garantir que entes idôneos, e não criados com objetivos escusos para fins específicos, atuem em juízo, sendo permitido ao magistrado, então, exercer a valoração tanto para afirmar a legitimidade como para negá-la. Como bem ressalta José Marcelo Vigliar, os critérios da lei são válidos, mas absolutamente insuficientes, pois o cumprimento do "compromisso cartorial" é das tarefas mais simples, que não pode conferir a uma associação, depois de um ano, o "título" de representante adequado ${ }^{147}$. Diante disso, tem-se como imperiosa a verificação da representatividade adequada para se afirmar a legitimidade.

Ademais, a observância da presença do instituto poderia se dar também a partir da própria interpretação ampliada do artigo $6^{\circ}$ do diploma processual, que estabelece a necessidade do interesse para estar em juízo, condicionando os legitimados a

\footnotetext{
${ }^{146}$ NUNES, Rizzato. Comentários ao Código ..., Op. Cit., p. 772/773.

${ }^{147}$ De acordo com o autor "a representação adequada é condição que se conquista. Essa conquista surge de atividade diuturna. Essa qualidade não pode decorrer do que está escrito num 'contrato' de formação de uma pessoa jurídica de direito privado. Concordo que essas exigências devam ser mantidas. Mas devem ser as mínimas. Mais que esses requisitos, deve-se conceder ao juiz do caso concreto a análise do efetivo compromisso que guarda com a causa (seja a do consumidor, seja a do meio ambiente etc.) (VIGLIAR, José Marcelo de Menezes, "Defendant class action brasileira ...", Op. Cit., p. p. 319).
} 
demonstrá-lo. Ainda que se trate de legitimidade extraordinária nos processos coletivos, não está imune a verificação do interesse, que é um dos critérios de aferição da representatividade adequada, sem o que não se poderá falar em legitimidade.

Assim, com base na lei atualmente em vigor, já é possível ao magistrado aferir a existência do requisito da representatividade adequada para afirmação da legitimidade das associações, o que também pode se dar para verificação de seu interesse.

Os Tribunais têm, aos poucos, adentrado o tema, inicialmente remetendo a análise para a pertinência temática com os direitos tutelados, pois, via de regra, a legitimidade é aceita com base na simples verificação do bem dentre os previstos no estatuto social como aptos à proteção. Nesse sentido, o Superior Tribunal de Justiça, em acórdão relatado pela Ministra Nancy Andrighi, já decidiu que "a pertinência subjetiva da entidade associativa de defesa do consumidor para ajuizar ação coletiva bem como a possibilidade jurídica do pedido se manifestam pela natureza dos interesses e direitos tutelados - individuais homogêneos" ${ }^{148}$. No entanto, apesar de ainda parcial a análise, esse já é um passo para se atingir a efetiva observância da representatividade adequada pelos Tribunais.

Sem dúvida, seria mais profícua a alteração legislativa para que tal não restasse apenas subentendido pela interpretação sistemática e conjuntural da norma, mas, ao contrário, expressamente disposto, como requisito de observância obrigatória pelo juiz. Contudo, essa alteração legislativa não foi abarcada pelo Projeto em tramitação, que, como antes se anotou, nem mesmo estabeleceu a adequação da representação como princípio, pois, se o tivesse feito, a aplicação dele seria isenta de dúvidas. A verdadeira razão é que ainda existe temor de conferir-se mais esse poder discricionário ao juiz, mas o certo é que ele já existe e a recusa da alteração legislativa tenta obstar uma situação de fato já permitida pela própria lei posta, o que não faz sentido.

\subsubsection{A legitimação da pessoa física}

${ }^{148}$ REsp 761.114/RS, Rel. Ministra NANCY ANDRIGHI, TERCEIRA TURMA, j. 03.08.06. 
Em estudo sobre os direitos coletivos realizado em 1977, Cappelletti, não via como adequada a conferência de legitimidade para a defesa desses direitos às pessoas físicas, salientando a falta de capacidade do indivíduo isoladamente considerado para tanto. Em suas palavras, aduziu que "o consumidor isolado, sozinho, não age; se o faz é um herói; no entanto, se é legitimado a agir não meramente para si, mas pelo grupo inteiro do qual é membro, tal herói será subtraído ao ridículo destino de Dom Quixote, em vã e patética luta contra o moinho de vento. Os heróis de hoje não são mais, pois sim, os cavaleiros errantes da Idade Média, prontos a lutar sozinhos contra o prepotente em favor do fraco e inocente"149. Todavia, não cremos que se possa afirmar tenha, desde então, permanecido igual essa situação.

A legislação brasileira atualmente em vigor, como antes se referiu, afasta a legitimação concorrente de cada um dos indivíduos para a defesa dos interesses difusos ou coletivos de natureza individual divisível, o que se dá por não se entender a pessoa física como dotada de elementos suficientes para tanto. As pessoas físicas são apenas legitimadas, no ordenamento brasileiro, estritamente a promover a ação popular, para defesa do patrimônio público, não podendo defender qualquer direito além dessa esfera, nem mesmo aqueles individuais homogêneos, a não ser por meio de uma ação individual que verse exclusivamente sobre seu direito e que, mesmo se julgada procedente, não atingirá os demais interessados, que tenham uma situação jurídica idêntica. A ação popular, ainda assim, é instrumento de pouquíssimo uso nos Tribunais, já que não se encontram pessoas dispostas a arcar com os custos de uma ação dessa ordem em face do Poder Público, preferindo, como as associações, simplesmente levar a notícia ao Ministério Público para que este promova a ação cabível, o que acaba sendo também melhor aceito pelos julgadores, que veem com receio a atuação judicial da pessoa física na defesa de direitos coletivos $^{150}$.

Nos países de common law, a legitimação das pessoas físicas é prevista e constitui a base do próprio sistema de class actions. Por meio delas, como foi visto no

\footnotetext{
${ }^{149}$ CAPPELLETTI, Mauro. "Formações sociais e interesses .....”, Op. Cit., p. 137.

${ }^{150}$ É de se observar que a jurisprudência brasileira não adotou uma interpretação extensiva do cabimento da ação popular, após a edição da Lei da Ação Civil Pública e do Código de Defesa do Consumidor, o que poderia se cogitar, mediante um estudo analógico e complementar das três leis, apesar de as duas mais recentes não preverem a legitimação da pessoa física. Ao contrário, os julgados, vendo com receio a atuação individual do cidadão, mantiveram a ação popular restrita à defesa do patrimônio. Nesse sentido, as decisões do Superior Tribunal de Justiça (REsp 818.725/SP, Rel. Ministro LUIZ FUX, PRIMEIRA TURMA, j. 13.05.08; REsp 441.761/SC, Rel. Ministra DENISE ARRUDA, PRIMEIRA TURMA, j. 05.12.06).
} 
capítulo 2, uma pessoa física vem a juízo defender um direito, fazendo-o em relação a todos aqueles que possuem situação de fato ou de direito comum à sua, de forma que atua como um porta-voz do grupo (representante adequado) e a decisão dá-se de forma coletiva, em relação a todos na mesma situação.

Deve-se ressaltar que, no Brasil, apesar de a legitimação não estar prevista, ela pode dar-se por existente, em ações individuais, que visem à tutela de direitos coletivos, estritamente considerados. Nesses casos, a pessoa física ingressa com uma ação individual, em nome próprio, para tutela de um direito próprio, mas os resultados do julgamento favorável dessa ação atingem terceiros, na mesma situação jurídica. Exemplo desse fato é a ação promovida por vizinho de uma boate que pede seu fechamento em vista do barulho excessivo. Julgada procedente a ação, essa demanda individual produzirá efeitos em relação a todos os outros vizinhos igualmente prejudicados, de forma que, apesar de não ser tida por ação coletiva, pode-se dizer que se trata de uma ação individual com efeitos coletivos, na qual atuou o autor como um autêntico representante adequado do grupo de vizinhos, titulares do direito coletivo.

Essas situações revelam que não há razão para não se permitir se confira legitimidade à pessoa física ${ }^{151}$, além dos limites da ação popular, até porque direitos coletivos e individuais homogêneos mais próximos dos cidadãos, como o exemplo antes citado, são muito mais fáceis de proteção pelos próprios lesionados, do que o patrimônio público, cuja defesa depende de critérios técnicos às vezes inatingíveis pelo cidadão. Em vista disso, o Anteprojeto de Código Brasileiro de Direitos Coletivos, elaborado pelos estudiosos do tema, havia incluído a pessoa física no rol de legitimados. Essa disposição revelaria o crescimento da legislação brasileira, que iria impor às pessoas físicas a necessária responsabilidade na persecução de seus direitos e iria fazer das ações coletivas um instrumento mais eficaz de participação popular, em adição ao incremento da participação das associações civis, como antes se anotou.

\footnotetext{
${ }^{151}$ O Professor espanhol Pablo de Cabiedes já ressaltou essa necessidade, anotando que "tampoco debe obstar a ello el que, al defender su interés, el particular esté, directa o indirectamente, consiguiendo la defensa del interés de un conjunto o categoría de sujetos, redundando su actuación procesal en beneficio de un interés supraindividual. Y ello pues, en realidad, ese beneficio se produce por el puro efecto material de la sentencia como hecho jurídico (del meramente fáctico, material, en el caso de sentencias de condena; y del jurídico-material en las anulatorias). Si bien se mira, con la negación de su legitimación se viene a negar la posibilidad de existencia de intereses legítimos tutelables en el seno de situaciones jurídicas que no sean exclusivas (o litisconsorciales necesarias o plenamente cerradas en sus contornos subjetivos). (CABIEDES, Pablo Gutiérrez de. "Comentario al art. 3"”, in Comentários ao Código ..., Op. Cit., p. 83).
} 
É de se ressaltar que a legitimação das pessoas físicas está prevista no Código Modelo de Processos Coletivos para Ibero-América, referindo-se este tanto à defesa de interesses difusos e coletivos, como individuais homogêneos.

Todavia, igual previsão do Anteprojeto de Código Brasileiro de Processos Coletivos não consta no Projeto em tramitação no Congresso Nacional, pois, de acordo com os críticos do dispositivo, o Brasil não estaria preparado para as class actions, que podem gerar indenizações milionárias em detrimento daqueles que lesam os bens coletivos. No entanto, é de se recordar que, no Brasil, independentemente de quem venha a ser o autor da ação coletiva, na modalidade de class actions, só haverá a condenação genérica, cabendo a cada titular do direito liquidar seus danos, provando a existência concreta e específica deles, de maneira que as indenizações milionárias desatreladas da realidade não encontram seu obstáculo no legitimado ${ }^{152}$.

Outrossim, o grande medo dos legisladores brasileiros prende-se às fraudes, à colusão do autor coletivo com o réu para prejudicar a sociedade. Contudo, não se pode sempre partir do pressuposto de que essa será a regra e de que as pessoas agem por esse impulso. Barbosa Moreira já havia ressaltado, em estudo de 1983, quando apenas se previa a ação popular como forma de tutela coletiva de direitos, que não seria pensável que alguém tome uma iniciativa com fins unicamente fraudulentos. De qualquer forma, como o jurista então salientou, não se pode esquecer existir a figura do Ministério Público como custos legis, além dos poderes instrutórios do juiz e da possibilidade de intervenção de outros legitimados, o que atenua sensivelmente o perigo ${ }^{153}$.

\footnotetext{
${ }^{152}$ Como bem anota Ferraresi, não se pode eternamente pensar que não estamos maduros, sendo imprescindível que se imponha responsabilidade aos cidadãos na defesa dos interesses que lhes tocam (FERRARESI, Eurico, "A pessoa física como legitimada à ação coletiva", in GRINOVER, Ada Pellegrini e outros (coord.). Direito Processual Coletivo e anteprojeto de Código Brasileiro de Processos Coletivos, São Paulo, RT, 2007, p. 136/137).

${ }^{153}$ V. BARBOSA MOREIRA, José Carlos. “A Legitimação para a Defesa dos 'Interesses Difusos' no Direito Brasileiro". In Temas de Direito Processual, $3^{\mathrm{a}}$ série. São Paulo: Saraiva, 1984, p. 187.

O Professor Kazuo Watanabe já defendia a ampliação dos legitimados para a inclusão da pessoa física, ao menos desde a edição de 1999 do Código de Defesa do Consumidor comentado pelos seus autores. Dizia ele que, "por certo, após a perfeita assimilação pelo povo brasileiro do verdadeiro ideal colimado pelo Código, o que somente ocorrerá com a educação mais aperfeiçoada e mais abrangente, e principalmente com a diminuição do individualismo que nos marca profundamente, estaremos aptos, no futuro, à ampliação total, inclusive a cada indivíduo, da legitimação para agir para a tutela, a título coletivo, dos interesses e direitos dos consumidores" (WATANABE, Kazuo, "Disposições gerais"...., Op.Cit., p. 732).
} 
Assim, o problema da legitimação da pessoa física não é sua previsão em si, mas o controle que se faz desse ato, pois conferir-se legitimidade ao cidadão não traz qualquer prejuízo à defesa dos direitos coletivos, desde que exercida por pessoa idônea, séria e com propósitos coletivos, não meramente individuais e egoísticos, o que pode ser fiscalizado pelo magistrado, se alçada a representatividade adequada a princípio. A Professora Ada Pellegrini Grinover, por ocasião do XIII Congresso Mundial de Direito Processual, realizado em Salvador, no ano de 2007, salientou, no Relatório Geral sobre processos coletivos dos países de civil law, que a tendência, em termos de legitimação, é a sua ampliação, para que ela não fique restrita aos organismos privados e possa chegar a diversos segmentos da sociedade e seus representantes, como a pessoa física, as formações sociais e os entes públicos vocacionados para tanto, desde que exercido o correto controle sobre esses entes ${ }^{154}$.

Nesse sentido, assume especial relevância a representatividade adequada, pois esse é o meio de controle mais eficaz da atuação dos jurisdicionados na defesa dos interesses de ordem coletiva. Como bem anota Eurico Ferraresi, em comentário à legitimidade individual então prevista no Anteprojeto de Código Coletivo, a ideia não é que qualquer pessoa possa demandar coletivamente. "Os critérios são rígidos para a admissibilidade do pleito. O juiz aferirá se a pessoa física, ao defender o meio ambiente, por exemplo, apresenta credibilidade, capacidade e experiência nesse tipo de embate. Também será observado o histórico do autor na proteção judicial ou extrajudicial dos direitos supra-individuais, bem como sua conduta em outros casos", fazendo-se respeitar, pois, o verdadeiro princípio da representatividade adequada ${ }^{155}$.

\footnotetext{
${ }^{154}$ V. GRINOVER, Ada Pellegrini. Os Processos Coletivos nos Países ....., Op. Cit., p. 236/237. De acordo com a Professora, a legitimação mista extensa "responde ao anseio do mais amplo acesso à justiça e ao princípio da universalidade da jurisdição: um número cada vez maior de pessoas e uma tipologia cada vez mais ampla de causas que acendem à justiça. E, para evitar os possíveis abusos, existem instrumentos adequados, como o controle de órgãos públicos (existente em vários países) e os pesados encargos para a litigância de má-fé (como no Código Modelo de Processos Coletivos para Ibero-América e no ordenamento brasileiro)".

155 V. FERRARESI, Enrico. Ação popular, ação civil pública e mandado de segurança coletivo: instrumentos processuais coletivos. Rio de Janeiro: Forense, 2009, p. 263.

Em igual sentido, Aluísio Mendes já ressaltou, ao analisar o Anteprojeto, a importância da análise da representatividade, anotando que "a abertura, em termos de legitimidade ad causam veio acompanhada do estabelecimento de requisitos específicos para a propositura da demanda coletiva, visando, assim, a um controle, em concreto, quanto à seriedade, viabilidade e importância da demanda coletiva que se pretende propor" (MENDES, Aluísio de Castro, “O Anteprojeto de Código Brasileiro ....”, Op. Cit., p. 26).
} 
Consoante se estudou no capítulo 3 deste trabalho, a representatividade adequada não é uma mera aferição de pertinência temática entre o legitimado e o direito colocado sub judice. É muito mais do que isso, pois, além da pertinência temática, deve atentar para a seriedade e a credibilidade daquele que vem ao Judiciário, havendo espaço amplo ao juiz para que exija prova de sua idoneidade, a fim de se evitar que aventureiros ou fraudadores dos direitos coletivos atinjam seus intentos. E não se pode olvidar que a observância do instituto deve se dar continuamente, durante todo o processar da demanda coletiva, podendo, em qualquer fase processual, ser substituído o autor da ação coletiva, se verificado que não preenche, ainda que em um momento ulterior, as condições da ação coletiva, dentre elas, a legitimidade coletiva, da qual é elemento integrativo a representatividade adequada ${ }^{156}$.

Acrescente-se, outrossim, e aqui se faz uma proposta de lege ferenda, que a admissão da pessoa física como legitimada à ação coletiva possibilitará, inclusive, que uma ação individual seja convertida em coletiva, como ocorre nos ordenamentos de common law, se o juiz considerar aquele autor individual um adequado representante de seu grupo, na defesa daquele direito trazido ao Judiciário. Esse tipo de decisão poderia ser utilizada para hipóteses em que se tem conhecimento de que serão inúmeros os autores individuais em relação a um mesmo fato, como ocorreu com a assinatura básica de telefone ou com o reajuste das cadernetas de poupança. É óbvio que tal disposição deveria vir cercada de inúmeras garantias, inclusive relacionadas à competência do órgão julgador, para evitar exposições pessoais ou de magistrados não condizentes com o ato. Todavia, para se chegar a esse ponto, depende o ordenamento brasileiro primeiro da admissão da legitimidade da pessoa física, mas esse passo legislativo é, sem dúvida, de ser cogitado para o sucesso futuro dos processos coletivos, atendendo a uma de suas funções, a de solucionar conflitos de forma molecular.

\footnotetext{
${ }^{156}$ Quanto a esse aspecto, interessante observar que o Projeto de Lei n. 5.139/09 prevê, em seu artigo $9^{\circ}$, que "não haverá extinção do processo coletivo, por ausência das condições da ação ou pressupostos processuais, sem que seja dada oportunidade de correção do vício em qualquer tempo ou grau de jurisdição ordinária ou extraordinária, inclusive com a substituição do autor coletivo, quando serão intimados pessoalmente o Ministério Público, a Defensoria Pública e, sempre que possível, outros legitimados para a adoção das providências cabíveis, em prazo razoável, a ser fixado pelo juiz". Esse dispositivo prende-se muito ao instituto da representatividade adequada, especialmente porque refere-se à substituição do autor coletivo, na hipótese de ausência de preenchimento das condições da ação, tendo sido criado justamente para se ter o instituto como princípio e como elemento integrativo da legitimidade, uma das condições da ação.
} 
De qualquer modo, não há nenhum prejuízo aos direitos coletivos permitir-se que sejam tutelados pela pessoa física que comprove ter os requisitos necessários para tanto, requisitos esses estampados no instituto da representatividade adequada, que, juntamente com os poderes instrutórios dos magistrados e da obrigatoriedade de participação ativa do Ministério Público como fiscal da lei, são suficientes para que a legitimação da pessoa física exista no nosso ordenamento, sem que se atinjam os males afirmados pelos contrários à ideia.

Não se pode olvidar, outrossim, que, tal qual se disse em relação às associações, a necessidade de se incrementar a participação popular é premente no sistema brasileiro, sendo um meio muito eficaz conferir-se a legitimidade para a defesa coletiva pelas pessoas físicas. Com isso, se fará valer também diversos princípios constitucionais, que preveem a participação dos cidadãos nas esferas política, econômica e sociais, com proibição da obrigatoriedade de associação (artigo $\left.5^{\circ}, \mathrm{XX}\right)$.

\subsection{As ações coletivas passivas}

Ultrapassado o estudo dos entes legitimados - ou possíveis legitimados - para a ação coletiva, mister se faz adentrar o estudo das ações coletivas passivas, pretendendo-se, como se salientou na premissa deste capítulo, comprovar que, apesar da ausência de regulamentação legal específica, elas já existem no direito brasileiro e que o instituto base deste trabalho - a representatividade adequada - já tem aplicação nesse tipo de ação.

O estudo das ações coletivas passivas poderia ser realizado em capítulo próprio, devido às suas inúmeras facetas, mas preferiu-se fazê-lo conjuntamente com a legitimidade, em vista de ser esse seu aspecto mais importante, no que toca ao presente trabalho, visto residir na legitimidade a maior controvérsia quanto ao cabimento das ações passivas $^{157}$. Esse tipo de ação não é ainda muito estudado no Brasil, quiçá pela ausência de

\footnotetext{
${ }^{157}$ De acordo com José Marcelo Vigliar, o maior problema para a admissão das ações passivas não seria a identificação do legitimado, mas, sim, o regime da coisa julgada aplicável (VIGLIAR, José Marcelo de Menezes, "Defendant class action brasileira ...", Op. Cit., p. 312/313). No entanto, pela forma como o ordenamento brasileiro trata a coisa julgada coletiva, esse é um problema generalizado de todo o processo coletivo, não sendo diferente em relação à ação ativa. Todavia, ele não toca ao cabimento da ação, mas, sim, às consequências da decisão, de forma que é sim a legitimidade o maior problema do cabimento desse tipo de ação.
} 
previsão legal específica de seu cabimento, mas a menção de sua aplicação prática revela ser essencial neste trabalho.

Importante, de início, definir ação coletiva passiva, para o que emprestamos o preciso conceito de Fredie Didier, que ressalta que "haverá ação coletiva passiva quando um agrupamento humano (titular do direito coletivamente considerado) for colocado como sujeito passivo de uma relação jurídica na petição inicial - demanda-se contra os interesses de uma dada comunidade, coletividade ou grupo de pessoas"158. Diante desse conceito, resta claro que a pretensão de estudo é das ações coletivas passivas originárias, não aquelas derivadas, como a hipótese de reconvenção, embargos do devedor, ação rescisória, nas quais a figura do grupo será colocada no pólo passivo de uma ação, mas atrelada a uma outra existente ou que já tenha existido.

Saliente-se, outrossim, que as ações passivas são vistas com certo receio pelos julgadores, pelos legisladores e pela própria coletividade, tanto no ordenamento brasileiro quanto naqueles alienígenas a que se teve acesso, pois existe uma tendência de proteção dos interesses do grupo. Talvez por serem afeitos a mais pessoas, apresentarem, muitas vezes, carga social relevante e, igualmente, não terem seus titulares claramente identificados, é natural pensar neles como os frequentemente ofendidos e sujeitos à proteção. Ocorre que a coletividade também pode violar direitos alheios, sendo, assim, materialmente possível que seja inserida no pólo passivo de ações ${ }^{159}$.

Primeiramente, serão analisadas as ações passivas no ordenamento de common law, passando-se, após, ao estudo das ações no ordenamento brasileiro, que teve aquele como inspirador, como sucede, de certa forma, com grande parte do processo coletivo.

\subsubsection{As defendant class actions do direito norte-americano}

\footnotetext{
${ }^{158}$ V. DIDIER JÚNIOR, Fredie. "O controle jurisdicional da legitimação coletiva e as ações coletivas passivas (o art. 82 do CDC)”, in Revista Dialética de Direito Processual, n. 25, abr/2005, p. 52.

${ }^{159}$ Quanto a esse aspecto, Diogo Maia, na introdução de sua dissertação de mestrado específica sobre o tema, salienta que "a proteção e o favorecimento conferidos ao grupo no litígio coletivo estão fortemente arraigados em todo o sistema processual brasileiro, de forma que, às vezes, se obscurece a visão de que nem sempre a coletividade é a vítima ou de que nem sempre o grupo precisa de proteção" (MAIA, Diogo Campos Medina. Ação Coletiva ..., Op. Cit., p. 1).
} 
A Rule 23 do ordenamento norte-americano prevê a existência de ações coletivas passivas, porque estabelece, já nos seus pré-requisitos (a) que "one or more members of a class may sue or be sued as representative parties on behalf the class". A partir dessa disposição de que os membros podem ser demandados numa ação coletiva, tem-se como expressamente prevista por aquele ordenamento a ação passiva, que é denominada pela doutrina e pelas Cortes como defendant class action, em oposição à plantiff class action, que é a ação ativa.

No entanto, a previsão limita-se ao texto legal antes transcrito, não existindo nenhuma outra disposição específica a regulamentar as ações passivas, pelo que se aplicam a elas aquelas mesmas previsões das ações ativas. É interessante anotar, como o faz com propriedade Gidi, que a ação passiva não deve ser utilizada como uma ação ativa às avessas, ou seja, não deve ser promovida por um potencial réu como meio de obter um provimento que obstaculize a pretensão do grupo ${ }^{160}$. A ideia da ação passiva é, ao contrário, permitir a defesa de um direito ameaçado ou violado por um grupo de maneira concentrada e por meio de uma única demanda.

A própria possibilidade de existência das defendant class actions já chegou a ser questionada nas Cortes norte-americanas. Contudo, a previsão pela Rule 23 suplanta alegações de inconstitucionalidade, de forma que os julgados dos Estados Unidos sempre abarcam a possibilidade da existência da ação em tese, em relação a que deve ser mencionado o famoso caso Smith v. Swormstedt (57 U.S. 288), julgado em dezembro de 1853. De acordo com esse julgamento, "the rule is well established, that where the parties interested are numerous, and the suit is for an object common to them all, some of the body may maintain a bill on behalf of themselves and of the others; and a bill may also be maintained against a portion of a numerous body of defendants, representing a common interest" $" 161$.

\footnotetext{
${ }^{160}$ Gidi ressalta que, na estrutura processual americana, "isso não é uma ação coletiva passiva, mas uma ação coletiva ativa iniciada pelo réu. Não há interesse processual em propor uma demanda em forma coletiva contra todo o grupo", sem que exista um direito violado ou, ao menos, ameaçado. Assim, uma ação exclusiva para afirmar que uma conduta é licita é desprovida de interesse (GIDI, Antonio. A Class Action como instrumento ...., Op. Cit., p. 392).

Por outro lado, Mullenix anotou, por ocasião do XIII Congresso de Direito Processual, em 2007, que, no Canadá, admite-se a ação coletiva passiva, como forma de evitar a proliferação de ações ativas, o que se enquadra nessa hipótese afastada por Gidi (V. MULLENIX, Linda e outros. Os Processos Coletivos nos Países ....., Op. Cit., p. 285/286).

${ }^{161}$ Extraído de http://openjurist.org/57/us/288/william-smith-v-leroy-swormstedt-
} 
Esse caso foi o que firmou o posicionamento dos Tribunais quanto à admissibilidade das ações coletivas passivas. Ao longo dos anos, todavia, foi restando assente a necessidade de observância de seus requisitos ((a) e (b) da Rule 23), em especial o da representatividade adequada, que é colocada como ponto fulcral para a admissão das ações passivas. Exemplo disso é verificado no caso Kerney v. Fort Griffin Fandangle Association Inc. (624 F.2d 717), julgado em 22 de agosto de 1980 pela United States Court of Appeals, Fifth Circuit ${ }^{162}$.

A doutrina alerta que a ação coletiva passiva é vista com grande cautela pelos juízes norte-americanos, até porque seus requisitos são de muito mais difícil verificação do que nas ações ativas. Tal qual ocorre com as ações ativas, o class defendant deve ser um membro da classe e ter, pois, interesse direto na causa. Pedro Dinamarco salienta a dificuldade de escolha desse representante, pois quem o faz é o autor da ação, cabendo ao magistrado verificar se ele é adequado para a função, o que revela a necessidade de uma análise cuidadosa, para evitar que restem mau defendidos os interesses da classe em processo cuja decisão terá eficácia erga omnes, como é sempre no ordenamento estadunidense, despontando como proeminente a estrita observância da representatividade adequada ${ }^{163}$.

Essa preocupação com a representatividade adequada decorre de um problema prático bastante evidente, qual seja, o fato, como antes se disse, de o representante ser escolhido pela parte contrária e não pelo próprio autor, que se afirma um representante, como nas ações ativas. E, por ser apontado representante, muitas vezes, esse

\footnotetext{
${ }^{162}$ No que toca a esse ponto, decidiu o Tribunal: "Both rules 23 and 23.2 expressly contemplate the possibility of defendant class actions and require that the representative parties fairly and adequately protect the interest of the class members. In permitting a class action to proceed, a district court determines adequacy of representation as a threshold matter. Moreover, the court has the power and the duty to ensure that all defendants be given adequate notice of the action and an opportunity to present individual defenses if desired. Should the district court fail to afford any defendant due process, he would be entitled to have an adverse judgment set aside or reversed on appeal. It is therefore premature for defendants to object to a lack of personal notice and service on the unnamed defendants" (http://openjurist.org/624/f2d/717/kerney-ii-vfort-griffin-fandangle-association-inc).

${ }^{163}$ V. DINAMARCO, Pedro da Silva. Ação Civil ..., Op. Cit., p. 157.

A Professora Ada Pellegrini, em trabalho trazido pelo Professor Kazuo Watanabe, ressalta essa absoluta necessidade, afirmando que "condição sine qua non para a admissibilidade da ação contra a classe, em qualquer ordenamento, é de atribuir ao juiz papel central de identificar a referida classe, e isto porque a adequacy of representation, nesse caso, é efetivamente condição necessária e suficiente para que a sentença possa vincular todos os componentes da classe, independentemente de sua participação individual no processo" (GRINOVER, Ada Pellegrini, "Ações coletivas ibero-americanas..., Op. Cit., p. 3/12, citada por WATANABE, Kazuo, "Disposições gerais"...., Op.Cit., p. 827).
} 
membro do grupo não o quer ser (unwilling representative), pois não quer ter como seu encargo e sua obrigação a defesa do grupo. Essa circunstância pode fazer o juiz suspeitar de sua adequação, mas é de se ressaltar que, ainda que o representante escolhido recuse o mister, o juiz, preocupado com a adequada defesa dos interesses da classe, se considerá-lo adequado, pode mantê-lo, desde que tal não configure um ônus demasiadamente injusto ao representante, ou seja, desde que não exista uma escusa justificável para sua ausência de vontade $^{164}$.

No julgamento do caso Marcera v. Chinlund 595 F.2d 1231, pela United States Court of Appeals, Second Circuit, em 27 de fevereiro de 1979, decidiu-se em manter um representante que não o queria ser, salientando-se que a "Rule 23(a) (4) does not require a willing representative but merely an adequate one. It will often be true that, merely by protecting his own interests, a named defendant will be protecting the class. Where, as here, the legal issues as to liability are entirely common to members of the defendant class, there is little reason to fear unfairness to absentees" ${ }^{\prime 165}$. Ou seja, se o membro do grupo consegue defender a si de modo vigoroso, também o fará em relação à classe, de maneira que não pode alegar desinteresse para eximir-se da obrigação.

Desta feita, observa-se que as ações coletivas passivas não recebem grande atenção específica da doutrina ou dos julgados no ordenamento norte-americano, revelando-se elas apenas como mais uma faceta das class actions, o que é justificado até pela própria ausência de distinção legal a respeito. De qualquer modo, para a aceitação das defendant class actions pelos Tribunais, o requisito que mais é ressaltado é a representatividade adequada, pois, ao ser uma ação promovida, em tese, para prejuízo do grupo, a certeza de que ele está adequadamente defendido em juízo é fundamental para se cogitar da produção de qualquer efeito negativo em relação a ele, até porque, se o representante não for adequado, como se viu no capítulo 3, será um não-representante. Se isso ocorrer, o julgado poderá ser impugnado por ausência de representação adequada, por meio do instituto do collateral attack, cujo estudo será aprofundado no capítulo seguinte, não servindo a seus propósitos a ação coletiva passiva, que terá, então, efeitos limitados às efetivas pessoas que participaram do processo.

\footnotetext{
${ }^{164}$ V. DINAMARCO, Pedro da Silva. Ação Civil ..., Op. Cit., p. 157, e GIDI, Antonio. A Class Action como instrumento ...., Op. Cit., p. 397 e 406/407.

${ }^{165}$ Extraído de http://openjurist.org/595/f2d/1231/marcera-v-chinlund
} 


\subsubsection{Tratamento e aplicação do instituto no Brasil}

No texto legal brasileiro, não há qualquer previsão da existência das ações coletivas passivas originárias, o que também inexiste no Projeto de lei em tramitação no Congresso Nacional. O Anteprojeto de Código Brasileiro de Processos Coletivos continha capítulo próprio destinado às ações passivas, mas o Projeto, infelizmente, ignorou, como adiante se verá, uma situação já existente nos Tribunais brasileiros e essencial para o desenvolvimento dos processos coletivos.

O texto do Anteprojeto permitia que qualquer espécie de ação fosse promovida contra uma coletividade organizada, ainda que essa não tivesse personalidade jurídica, desde que aferida a representatividade adequada e se visasse a uma tutela de interesses difusos e coletivos de interesse social.

O Código Modelo de Processos Coletivos para Ibero-América prevê, igualmente, a existência de ações coletivas passivas originárias, em relação a qualquer espécie de direito, desde que se observe o requisito da representatividade adequada, o bem jurídico tutelado seja transindividual e se revista de caráter social, com o que se revela que o Anteprojeto caminhava a seu lado.

Apesar da ausência de previsão legal específica das ações coletivas, elas existem de fato, são cada vez mais aceitas pelos Tribunais e representam um instrumento bastante relevante para a correta tutela dos direitos coletivos. E essa aceitação decorre, além da premente necessidade de existência das ações coletivas passivas, do fato de que a legislação atualmente vigente já prevê, entremeada com outros dispositivos, hipóteses de cabimento de legitimação passiva dos entes de defesa dos interesses coletivos.

A justificativa mais encampada pelos estudiosos do tema é a de que o artigo 83 do Código de Defesa do Consumidor admite "todas as espécies de ações capazes de propiciar sua [dos direitos e interesses protegidos por este código] adequada e efetiva tutela"166. Certamente essa é uma abertura legal, dos mesmos moldes daquela existente no

166 Nesse sentido, se posicionam os Professores Kazuo Watanabe e Ada Pellegrini (GRINOVER, Ada Pellegrini, Ações coletivas ibero-americanas..., Op. Cit., p. 3/12, citada por WATANABE, Kazuo, 
direito norte-americano, que já impede o afastamento de plano das ações passivas. Mas há outras permissões legais de cabimento ainda trazidas pelos doutrinadores.

A Professora Ada Pellegrini também menciona a abertura, conferida pelo artigo $5^{\circ}, \S 2^{\circ}$, da Lei da Ação Civil Pública, de o Poder Público ou as associações legitimadas habilitarem-se como litisconsortes de qualquer das partes ${ }^{167}$. Essa previsão, como ressaltam os autores, por certo também revela que o ordenamento brasileiro não é avesso à ação passiva, já que admite que os legitimados figurem não só como autores, mas também como réus, defendendo interesses da coletividade que seja demandada em juízo.

No mesmo estudo, os Professores ainda mencionam a convenção coletiva de consumo, prevista no artigo 107 do Código de Defesa do Consumidor, como permissivo legal para as ações coletivas passivas. Nesse dispositivo, estabelece-se a possibilidade de um ato bilateral entre fornecedores e consumidores atribuir direitos e obrigações a ambas as partes, obrigações essas que, se não forem cumpridas, ensejarão uma ação judicial, obviamente na forma coletiva, tendo em cada pólo um representante do grupo. Assim, também nesse ponto, inquestionável tratar-se de uma hipótese de cabimento.

Diogo Maia ${ }^{168}$ fundamenta o cabimento das ações coletivas passivas no artigo $5^{\circ}, \mathrm{XXXV}$, da Constituição Federal, que estabelece o princípio da inafastabilidade do controle judicial sobre todos os atos. Segundo o autor, se fosse negada, já em tese, a possibilidade de existência da ação passiva, seria violado esse princípio. Ressalta ainda o autor que o cabimento se justifica, outrossim, em face do disposto no artigo $6^{\circ}$ do Código de Processo Civil, pois o sentido do verbo "pleitear" constante da norma pode se estender a defender e não só a propor uma ação. Isso decorre, logicamente, do fato de o mencionado dispositivo também dever ser aplicado aos réus, que devem ter interesse tal qual os autores.

Por fim, no que toca às permissões de cabimento previstas na lei em vigor, Jordão Violin ${ }^{169}$ ainda ressalta duas outras: o caráter duplamente coletivo das ações

\footnotetext{
“Disposições gerais”...., Op.Cit., p. 831), Fredie Didier (DIDIER JÚNIOR, Fredie. “O controle jurisdicional da ....", Op. Cit., p. 54), Pedro Lenza (LENZA, Pedro, Teoria ....., Op. Cit., p. 198/205) e Jordão Violin (VIOLIN, Jordão. Ação Coletiva Passiva..., Op. Cit., p. 99).

167 V. GRINOVER, Ada Pellegrini, Op. Cit., citada por WATANABE, Kazuo, "Disposições gerais"...., Op.Cit., p. 830 .

${ }^{168}$ V. MAIA, Diogo Campos Medina. Ação Coletiva ...., Op. Cit., p. 68/89.

${ }^{169}$ V. VIOLIN, Jordão. Ação Coletiva Passiva..., Op. Cit., p. 100/101.
} 
de controle de constitucionalidade, e a Circular 2.766/97 do Banco Central do Brasil, que versa sobre os grupos de consórcio e estabelece a representação ativa ou passiva do grupo em juízo pela administradora, para defesa dos direitos e interesses coletivamente considerados, e para a execução do contrato de consórcio.

Desta feita, como se verifica, a legislação brasileira não veda a existência de ações coletivas que possuam em seu pólo passivo o representante do grupo, pois há inúmeros dispositivos legais que comprovam a previsão explícita de seu cabimento $^{170}$. É de se observar que bastaria, em tese, como é suficiente à legislação norteamericana, a previsão genérica de seu cabimento para afirmá-la, impondo-se a existência dos demais requisitos às avessas da ação ativa. Ocorre que o ordenamento estadunidense possui, como princípio dos processos coletivos, a representatividade adequada, que é essencial, como antes se anotou, para que se tenha como de fato possíveis as ações passivas. Sem a sua observância, poderá haver violação do devido processo legal, porque se imporá uma decisão contrária ao grupo a entes que não puderam participar da relação jurídica processual. A análise da coisa julgada coletiva, inclusive nas ações passivas, será realizada no capítulo subsequente, mas, de qualquer modo, como antes se anotou em relação às ações passivas, a observância da representatividade adequada é essencial. Assim, como esse princípio não está estabelecido no ordenamento brasileiro, era essencial - para regulamentar as ações passivas, não para permitir seu cabimento, porque isso já existe - o tratamento da matéria pela lei, o que, infelizmente, ainda não ocorreu.

Visando exatamente a fazer valer o princípio da representatividade adequada, o Anteprojeto de Código Brasileiro de Processos Coletivos previa, no capítulo das ações coletivas passivas, que o Ministério Público e os órgãos públicos legitimados para a ação ativa não poderiam ser considerados representantes adequados para a ação passiva (parágrafo único do artigo 38), o que tem sua razão de ser, pois não são entes capazes de defender a coletividade. Isso porque a ação passiva não é, como antes afirmado, uma ação ativa às avessas, de forma que ninguém poderá ingressar com uma ação contra o ente ministerial para ter reconhecido, por exemplo, que está de acordo com as normas ambientais. A ação passiva decorrerá sempre de um fato e uma violação concreta de um

${ }^{170}$ O Professor Mancuso admitiu sem maiores indagações quanto ao cabimento da ação passiva ao tratar da ação civil pública, tendo como certo que os representantes do grupo poderiam ser colocados no pólo passivo da ação, respondendo todos, solidariamente, pelos prejuízos acarretados (MANCUSO, Rodolfo de Camargo, . Ação Civil Pública em ..., p. 164/170. 
direito individual ou coletivo (aí se terá a ação duplamente coletiva), em relação a fatos que não necessariamente sejam de conhecimento dos órgãos públicos ${ }^{171}$. Assim, é evidente a inadequação desses entes para tanto.

De qualquer forma, apesar da apenas indireta previsão legislativa das ações passivas, elas já existem no ordenamento brasileiro e são cada vez mais comumente usadas e aceitas pelos Tribunais.

Uma hipótese comum de ação coletiva passiva é aquela promovida em face de sindicatos, para que a decisão tenha validade para toda a categoria. Em pesquisa realizada nos Tribunais brasileiros, foi possível localizar, por exemplo, ação promovida pela Escola Técnica Federal contra Sindicato de Servidores da Educação, objetivando que a classe dos servidores desocupassem prédio do estabelecimento de ensino, que não poderia ser ocupado para manifestação grevista. Trata-se de uma típica ação coletiva passiva, em que o sindicato representou o grupo de servidores e teve uma decisão contrária ao grupo que atingiu todos os seus membros ${ }^{172}$. As ações contra sindicatos, enquanto adequados representantes das categorias que representam, são bastante encontradas também com relação a greves de categorias que prestam serviços essenciais, com o objetivo de condenar o grupo ao retorno ao trabalho ou ao pagamento de indenização pelos prejuízos sofridos com a paralisação ${ }^{173}$, ou ainda de um próprio membro do grupo, contra o sindicato, enquanto representante dessa classe, por danos que lhe foram cometidos pelos demais trabalhadores, ao tentar ele ingressar no local de trabalho durante uma greve e ser impedido pelos demais ${ }^{174}$.

Mas não só os sindicatos têm figurado no pólo passivo de ações coletivas. Outros entes, que não possuem dentre suas finalidades a de representar os seus membros, como ocorre com os sindicatos, que são criados justamente com essa finalidade,

\footnotetext{
${ }^{171}$ José Marcelo Vigliar defende a "total incompatibilidade do Ministério Público em figurar no pólo passivo de ações coletivas" (v. VIGLIAR, José Marcelo de Menezes, "Defendant class action brasileira ...", Op. Cit., p. 314/315).

${ }^{172}$ Tribunal Regional Federal da $1^{a}$ Região, Apelação Cível n. 95.01.36122-5/PA, Rel. Des. Ítalo Mendes, j. 14.09.00.

173 V., dentre outros, Tribunal Superior do Trabalho, RODC - 853/2005-000-15-00, Rel. João Oreste Dalazen, j. 01.06.07; Tribunal de Justiça de Santa Catarina, Apelação Cível 97.001057-5, Rel. Des. Nilton Macedo Machado, 10.12.98; Tribunal de Justiça de São Paulo, Agravo de Instrumento n. 607.276-5/2, Rel. Des. Thales do Amaral, j. 22.03.07; Tribunal de Justiça de São Paulo,.Apelação Cível n. 220.278.4, Rel. Des. Ênio Zulliani, j. 02.06 .06

${ }^{174}$ Tribunal de Justiça de São Paulo, Apelação Cível n. 505.153-4, Rel. Des. Marco César, j. 19.06.07.
} 
também têm sido admitidos pelos Tribunais no pólo passivo de ações de cunho estritamente coletivo. Um exemplo disso são as ações promovidas em face do Movimento dos Trabalhadores Sem Terra (MST), voltadas à desocupação de terras por integrantes de seu movimento ${ }^{175}$.

Nessa hipótese, é interessante a própria admissão da legitimidade do MST, pois, muitas vezes, os ocupantes podem utilizar-se da bandeira do movimento, mas sequer serem formalmente a ele ligados, o que poderia ser objeto de questionamento pelos seus líderes. Houve casos em que isso ocorreu, mas a legitimidade passiva restou afirmada pelo Tribunal, com base, justamente, na impossibilidade de identificação ou de citação de todos os ocupantes de uma área, que prescindiam de identificação. Em julgamento pelo Tribunal de Justiça de Santa Catarina, deixou-se assente exatamente esse aspecto: "no caso em tela, o esbulho é exercido por uma massa de pessoas, de difícil individualização e identificação. Exigir da autora o arrolamento de todos os envolvidos para se dar prosseguimento a demanda postulada, estar-se-ia obstando à requerente o seu acesso à justiça, visto que ficaria impossibilitada de cumprir a determinação legal”176.

Foi possível localizar julgados que acabaram por admitir a presença do Movimento dos Trabalhadores Sem Terra no pólo passivo de ações unicamente com base na impossibilidade fática de atendimento de todos os requisitos do artigo 282 do Código de Processo Civil $^{177}$ e a necessidade de não se impedir o acesso à justiça. Todavia, em julgado que assim decidiu, não se atentou que a questão foi analisada com base no direito processual clássico, ignorando a faceta verdadeiramente coletiva desse processo, que, se aceita fosse, revelaria quão desnecessária é a discussão sobre esse requisito da petição inicial previsto no diploma processual ${ }^{178}$.

\footnotetext{
175 Dentre outros julgados, extinto $1^{\circ}$ Tribunal de Alçada Civil de São Paulo, Agravo de Instrumento n. 875.905-7, Rel. Des. Beretta da Silveira, j. 21.09.99; extinto $1^{\circ}$ Tribunal de Alçada Civil de São Paulo, Agravo de Instrumento n. 1.054.991-8, Rel. Des. Luiz Antonio de Godoy, j. 27.11.01; Tribunal de Justiça do Mato Grosso do Sul, Apelação Cível n. 63.864-4 - Rel. Des. Joenildo de Sousa Chaves, j. 17.08.99; Tribunal de Justiça do Rio Grande do Sul, Agravo de Instrumento n. 70017238601, Rel. Des. Rubem Duarte, j. 08.11.06.

${ }^{176}$ Tribunal de Justiça de Santa Catarina, Apelação Cível n. 98.013461-7, Rel. Des. Wilson Augusto do Nascimento, j. 22.05.01.

${ }^{177}$ Especialmente seu inciso II, que estabelece a necessidade de se indicar, na petição inicial, "os nomes, prenomes, estado civil, profissão, domicílio e residência do autor e do réu".

${ }^{178}$ Interessante transcrever a parte do acórdão que versa sobre esse aspecto: "Afirmam os Réus que o processo deve ser extinto, pois a inicial é inepta, tendo em vista que não foram indicados os nomes de todos os réus. Conforme bem decidiu a MM. Juíza Monocrática, 'a falta de individualização de todos os réus, de forma precisa, na inicial, não impede o prosseguimento do feito e nem é causa de sua extinção.' É este o
} 
A suposta falta de observância do Código de Processo Civil é ressaltada por Joaquim Falcão, quando tratou, em obra de 1984, dos conflitos urbanos de propriedade. Segundo o autor, a solução judicial dada para casos de invasão de propriedade abandona os preceitos desse diploma legal (referindo-se à necessidade de citação pessoal dos réus), chegando ele a afirmar que ignorou a Justiça se seus atos eram legais, optando "por procedimentos outros determinados pelo acordo mútuo explícito ou implícito, mas sempre de fato, de todos". Assim, no estudo realizado antes mesmo da Constituição Federal em vigor, já observou o autor a natureza coletiva não formalizada das invasões, que exigiam a adoção de mecanismos outros que não aqueles do processo civil tradicional $^{179}$.

Além dos exemplos antes mencionados, já encontrados, em profusão, nos Tribunais pátrios, uma série de outros poderiam ser trazidos, sempre em situações análogas, quando há efetiva representação adequada de um grupo que está violando ou ameaça violar direito alheio. Esse direito pode ser tanto de um particular, como é o caso das ações promovidas para desocupação de áreas por movimentos de sem terra, ou de um outro grupo, caso em que a ação será duplamente coletiva ${ }^{180}$. Nas hipóteses mencionadas, esse caráter dúplice é visto nas ações promovidas, em casos de greves, pelas Fazendas

entendimento adotado por esta Colenda Câmara, conforme se depreende de parte da fundamentação da Apelação Cível n ${ }^{\circ}$ 166.074-4, de relatoria do eminente Juiz Ronald Schulman, que transcrevo: 'Ora, as invasões, ou ameaças de sua prática, são fatos concretos e cotidianos. Por outro lado, a Constituição da República garante expressamente o direito de propriedade e o livre acesso ao Judiciário. É óbvio que a violação dessas garantias merece resposta deste Poder, pronta e eficaz, pena de se reduzir a lei apenas à sua letra, e nada mais. Calmon de Passos faz a pergunta: 'É possível a proposição da demanda contra pessoa não individualizada?' E o próprio mestre baiano responde: 'Sim. O Código menciona, em mais de um passo, a existência de interessados incertos e em muitas circunstâncias, essa incerteza será invencível. Nesta hipótese, o previsto no inciso II é dispensável por inatendível. A indeterminação do autor é que é de todo impossível' (Comentários ao Código de Processo Civil, Forense, III vol. $3^{a}$ ed., 1979, p. 216). Theotonio Negrão anota que "em caso de ocupação de terras por milhares de pessoas, é inviável a citação de todas para compor a ação de reintegração de posse, eis que essa exigência tornaria impossível qualquer medida judicial (STJ - RT 744/172, maioria). No mesmo sentido: Lex - JTA 146/96' ("Código de Processo Civil e Legislação Processual em Vigor", $31^{\mathrm{a}}$ ed., nota 5b ao art. 282, p. 356). Por isso que não se pode censurar a MM. Dra. Juíza a quo quando aceitou o pedido exordial tal como formulado, ante a impossibilidade natural de identificação de todos os réus. Não há que se falar, portanto, em descumprimento do disposto no artigo 282, II, do Código de Processo Civil”. (Tribunal de Justiça do Pará, Apelação Cível 166.065-5, Rel. Des. Marcus Vinícius de Lacerda Costa, j. 25.02.03).

${ }^{179}$ V. FALCÃO, Joaquim de Arruda, "Justiça Social e Justiça Legal: conflitos de propriedade no Recife", in FALCÃO, Joaquim de Arruda (org.). Conflito de direito de propriedade : invasões urbanas. Rio de Janeiro: Forense, 1984, p. 88/89.

${ }^{180}$ Afinal, como ressalta Fredie Didier, "na sociedade de massas, há conflitos de massa e conflito entre massas” (DIDIER JÚNIOR, Fredie. “O controle jurisdicional da ....”, Op. Cit., p. 56). 
Públicas, defendendo interesse coletivo da sociedade, contra sindicatos, que defendem o interesse coletivo da categoria que representam.

Há questionamentos doutrinários quanto à necessidade de $\mathrm{o}$ representante adequado, colocado no pólo passivo da ação, ser ente legalmente constituído, com personalidade jurídica, o que, por vezes, se afirma necessário ${ }^{181}$. Contudo, não compartilhamos desse entendimento, pois basta, no caso, que o réu represente adequadamente o grupo e afira o juiz, no caso concreto, se estão presentes os requisitos para tanto. Essa interpretação, como antes se ressaltou, deveria ser válida também para as ações ativas, mas, em relação às passivas, ela é ainda mais evidente, para não inviabilizar a própria existência delas. A própria hipótese de invasão de terras ou imóveis alheios é uma que se enquadra nisso, pois, se não se tratar de um movimento consolidado, restaria então inviabilizada a ação? Não parece razoável, especialmente se possível identificar um líder ou um movimento de fato em nome de quem se exerce a invasão.

Nesse sentido, Diogo Maia ressalta a possibilidade de a ação ser promovida contra grupo de fato, para o que faz analogia com a sociedade de fato, que são representadas em juízo, a teor do inciso VII, do artigo 12, do Código de Processo Civil, “pela pessoa a quem couber a administração dos seus bens". No entanto, ressalta o autor a necessidade de referidas associações terem um aspecto organizacional estabelecido, como também finalístico, o que se reveste na própria consciência de classe afirmada por ele como necessária ${ }^{182}$. Esse aspecto constitui um daqueles necessários para se afirmar a representatividade adequada, pois, certamente, se não existirem essas características e a aceitação do membro como pertencente àquela classe, representada por aquele ente, não se poderá cogitar de adequação da representatividade.

Sendo assim, resta evidente a já existência das ações coletivas no Brasil e, mais do que isso, a representatividade adequada como princípio, ainda que oculto ou diferentemente nominado, de observância essencial para o seu cabimento, que tem autorização e aplicação já com base na lei posta.

\subsection{Conclusões}

${ }^{181}$ V. VIOLIN, Jordão. Ação Coletiva Passiva..., Op. Cit., p. 131/133.

${ }^{182}$ V. MAIA, Diogo Campos Medina. Ação Coletiva ...., Op. Cit., p. 131/137. 
Diante do que se estudou neste capítulo, é possível afirmar-se que a aferição da representatividade adequada não está adstrita à análise legislativa prévia, mas ela pode - e deve - suceder a análise judicial, justamente para, em concreto, verificar a ligação objetiva da situação jurídica posta como suficiente a justificar a atuação daquele legitimado. Esta análise suplantaria a mera previsão de menção nos estatutos, previstas em relação as associações, sendo imperiosa a realização de um verdadeiro juízo de adequação, não só em relação às associações, como também ao Ministério Público, que hoje tem uma atuação indiscriminada, que se afasta, inclusive, de seus objetivos constitucionais e deveria ser - como com base na lei posta, como se demonstrou, já é possível ser - objeto de análise mais rigorosa pelos magistrados.

No que toca às associações, a análise da representatividade adequada se daria tanto ao verificar o preenchimento do requisito da existência, nos estatutos sociais da entidade legitimada, da finalidade de proteção dos direitos objeto da ação coletiva ou ao dispensar, em virtude da natureza e da importância dos direitos envolvidos, o requisito de constituição prévia da associação. Essa consideração deve ser feita pelo magistrado não se atentando simplesmente para a menção formal do requisito nos estatutos, mas para a efetiva atuação da entidade nesse sentido perante a sociedade.

Infelizmente, a lei brasileira parece que não dará um passo importante na defesa de direitos coletivos, com a admissão da pessoa física como legitimada para tanto, como previa o Anteprojeto de Código Brasileiro de Processos Coletivos, pois isso não consta no Projeto enviado ao Congresso Nacional. Com isso, deixou-se de fora também o instituto da representatividade adequada, como princípio expresso dos processos coletivos, princípio esse, no entanto, que permanecerá velado no sistema ${ }^{183}$, como hoje já o é, gerando dúvidas quanto à sua aplicação, que só traz, como se viu, benefícios para a defesa dos direitos coletivos. A observância do instituto é a única forma capaz de certificar, em cada caso concreto, o verdadeiro compromisso do autor coletivo com o objeto da causa e se o interessado se apresenta em juízo um mensageiro adequado aos interesses do grupo,

\footnotetext{
${ }^{183}$ Como ressalta Susana Costa, já se vê, em nosso ordenamento, "um comprometimento ideológico existente entre a entidade legitimada e o interesse em jogo no processo", o que garante a coerência do sistema e, mais do que isso, uma defesa satisfatória dos interesses metaindividuais da sociedade, preocupação que se traduz "exatamente no conceito de representatividade adequada, ou seja, na garantia de que o autor coletivo tenha a capacidade de bem representar a sociedade" (COSTA, Susana Henriques da. "O Controle Judicial da representatividade ...", Op. Cit., p. 972).
} 
evitando o mau uso da ação coletiva, como meio de prestígio individual, de abuso de atuação ou de conluio, com o objetivo de prejudicar os interesses que deveria proteger.

Assim, considerada a representatividade adequada nos termos aqui propostos, forçoso reconhecer a sua natureza de elemento integrativo do próprio conceito de legitimidade nas ações coletivas e não de mero requisito autônomo, de que prescinde aquele. Onde não estiver presente a adequada representação, legitimidade não haverá. No dizer de Gidi ${ }^{184}$, “o representante inadequado, portanto, é um não-representante”, de forma que será ilegítimo para atuar no feito. Somente com a efetiva observância desse requisito se terá como de fato aferida a legitimidade. E tal já é possível com base na lei posta, como trazido nesse capítulo, amplamente em relação aos legitimados.

Além desse aspecto, é de se concluir, pelo antes visto nesse capítulo, que a representatividade adequada é, de fato, instituto em aplicação no Brasil também no que toca às ações coletivas passivas, que, apesar de não expressamente previstas, têm seu cabimento permitido pela lei em vigor e, mais do que isso, têm sido progressivamente aplicadas pelos Tribunais. E tal só se mostra possível porque o instituto da representatividade adequada é, ainda que implicitamente, aferido pelos magistrados, evitando, com isso, que decisões proferidas contra a classe atinjam seus membros que não tiveram o direito de ter seu interesse ouvido no Tribunal, o que feriria o devido processo legal.

${ }^{184}$ GIDI, Antonio. A representatividade ...., Op. Cit., p. 70. 


\section{REPRESENTATIVIDADE ADEQUADA E COISA JULGADA}

A par da questão da legitimidade, analisada no capítulo anterior, o instituto da representatividade adequada também pode ter especial relevância para a formação da coisa julgada, especialmente no que toca à sua extensão subjetiva. Esse aspecto possui importância no estudo dos processos coletivos, pois é o ponto em que se verifica distinção considerável entre os sistemas de civil law e de common law e, mais do que isso, é aquele que atinge a vida prática dos indivíduos, pois determinará se, como e quem será atingido pelo conteúdo da decisão. Assim, por meio da coisa julgada, se terá o reflexo concreto final do objeto de um litígio.

Dessa forma, a análise desse instituto, dentro dos processos coletivos e em face da coisa julgada, revela-se essencial.

\subsection{Premissa}

O objetivo deste capítulo é analisar e refletir se o sistema brasileiro pode modificar de alguma forma a extensão subjetiva da coisa julgada, utilizando-se, para tanto, da representatividade adequada, como ocorre nos países de common law, sem que haja ofensa aos seus princípios constitucionais, buscando o incremento da efetividade dos processos coletivos no Brasil.

É certo que não se pode cogitar da simples transposição dos sistemas, pois se deve atentar para as circunstâncias particulares que conferem uma realidade diferente - social, cultural e jurídica - a cada um dos ordenamentos. Como ressalta Lenza $^{185}$, relativamente à eventual adoção do sistema norte-americano pelo brasileiro, "a transposição do referido sistema alienígena teve que se adaptar à realidade nacional, marcada pela deficiência na transmissão de informações aos jurisdicionados, muitos dos quais despidos de conscientização de seus direitos, enfim, um inegável distanciamento entre o Judiciário e o povo". Além disso, a doutrina vislumbra ser difícil a aplicação das regras do direito norte-americano ao sistema brasileiro, por entender que não haveria controle concreto da representatividade, de modo que um terceiro que não fosse

${ }^{185}$ LENZA, Pedro, Teoria Geral da Ação Civil Pública, São Paulo, RT, 2003, p. 223. 
adequadamente representado poderia se sujeitar a uma coisa julgada desfavorável, ferindo seu direito de participação em contraditório ${ }^{186}$.

Contudo, acredita-se haver modos de estender o alcance da coisa julgada, por meio da obrigatoriedade de observância do instituto da representatividade adequada no ordenamento brasileiro, sem que isso viole direitos garantidos na Constituição Federal, inclusive os interesses subjetivos individuais eventualmente envolvidos, mas também sem afastar a necessária segurança que deve ser conferida às partes, em especial ao demandado. Com isso, se traria uma solução para a hoje existente falta de isonomia no regime da coisa julgada em relação a cada um dos integrantes do pólo processual coletivo, sendo essa análise, pois, o escopo desse capítulo.

Para que o estudo possa ser o mais abrangente possível, será analisado, em primeiro lugar, o próprio conceito clássico de coisa julgada, verificando-se como se dá sua extensão subjetiva tanto no processo comum, no sistema brasileiro, que aqui é trazido como modelo de civil law, como naquele coletivo, em especial as distinções a ele aplicáveis. Após, será apresentado o instituto da coisa julgada no sistema de common law e, por fim, a maneira pela qual o instituto da representatividade adequada pode influir na formação da coisa julgada e na sua eventual extensão subjetiva, além dos limites atuais.

\subsection{Aspectos gerais da coisa julgada}

Coisa julgada constitui instituto do direito processual que se traduz na imutabilidade dos efeitos da sentença, garantindo que aqueles que participaram do processo não mais possam modificar o nele decidido. Desse modo, a relação jurídica existente entre eles se estabiliza, nos termos decididos pela sentença a que se confere a carga de imutabilidade.

Cuida-se, assim, a coisa julgada de uma opção política legislativa, visto o sistema ter optado por garantir a estabilidade e a segurança jurídica daquela solução trazida pelo Estado à vida das pessoas. É certo que a sentença é fruto de uma decisão sobre o que se leva ao conhecimento do juiz, podendo ocorrer, por má formação do material

${ }^{186}$ Cf. GRINOVER, Ada Pellegrini. "Da coisa julgada", in Código Brasileiro de Defesa ...Op. Cit., p. $804 / 806$. 
probatório, que o juízo de certeza por ele emitido não corresponda à verdade concreta. Todavia, ainda assim, sujeita a erros de percepção dos fatos pelo magistrado, essa "presunção de verdade" ou "ficção de verdade" trazida pelo julgador projeta efeitos para o mundo externo $^{187}$.

Na lição de Carnelutti, "con il giudicato se chiude il processo civile di cognizione”. O jurista italiano justifica, como antes ressaltado, a opção política do Estado, anotando que a coisa julgada tem considerável importância no aspecto da segurança, evitando que o processo torne-se infindável e não traga a efetiva solução da controvérsia ao mundo concreto $^{188}$. Ainda sujeita a erros, a estabilidade é um elemento importante, pois uma decisão desprovida de certeza é incapaz de dar ao indivíduo a segurança que a Constituição Federal assegura em seu artigo $5^{\circ 189}$.

A coisa julgada é ainda tida, no sistema de civil law e, em especial, no direito brasileiro, por força do disposto no inciso XXXVI, do artigo $5^{\circ}$, da Constituição Federal, como garantia constitucional, atuando tanto em favor do jurisdicionado, na forma antes alinhavada, como também em favor da própria instituição do Judiciário, pois sua existência impede repetição de atividade jurisdicional sobre o mesmo objeto e a mesma causa de pedir, gerando eficiência e racionalidade.

Diante disso, impende ressaltar que a coisa julgada é direito garantido pela Constituição Federal, tratando-se de instituto de suma relevância para se preservar o

187 Cf. DINAMARCO, Cândido Rangel. Instituições de Direito Processual Civil, III, $2^{\mathrm{a}}$ ed. São Paulo: Malheiros, 2002, p. 303.

${ }^{188}$ A coisa julgada "serve se non proprio a mettere ordine tra i contendenti, almeno a frenare il disordine; se non fosse così il processo civile non sarebbe mai sorto (...); perciò al giudicato non si può non riconoscere il valore pratico di uno strumento imperfetto ma indispensabile alla convivenza" (CARNELUTTI, Francesco. Trattato del Processo Civile, Napoli: Morano, 1958, p. 254/5).

${ }^{189}$ Quanto a esse aspecto, vale ser mencionada a lição de Dinamarco, que aponta exatamente a problemática da falta de segurança. Como afirma, "a função da coisa julgada tout court é a de propiciar segurança nas relações jurídicas, sabendo-se que a insegurança é gravíssimo fator perverso que prejudica os negócios, o crédito, as relações familiares e, por isso, a felicidade pessoal das pessoas ou grupos. A imutabilidade da sentença e de seus efeitos é um dos mais importantes pesos responsáveis pelo equilíbrio entre exigências opostas, inerente a todo o sistema processual" (DINAMARCO, Cândido Rangel. Instituições de ... III, Op. Cit., p. 296).

Também Camilo Zufelato deixa assente essa função, ressaltando que "há tempos foi afastada a correspondência entre a intangibilidade da sentença de mérito coma verdade dos fatos ou com a certeza dela proveniente. $\mathrm{O}$ fundamento sócio-político predominante no instituto da coisa julgada é a necessária imutabilização dos conflitos do ponto de vista processual, sem que haja uma intervenção que altere a realidade dos fatos subjacentes ao processo" (ZUFELATO, Camilo. Coisa julgada coletiva..., Op. Cit., p. 24/26). 
respeito à solução definitiva no litígio, "que tem na ordem pública o seu fundamento e na paz social o seu fim último". Como bem observa Paulo Roberto Medina, em vista de discussões atuais que visam a minimizar a força desse relevante instituto, o risco de encobrir injustiças não pode tirar a necessidade de preservação da coisa julgada, pois sempre haverá invocações de injustiça nas decisões por aqueles que perderam. Nunca se pode deixar de anotar, desse modo, que a coisa julgada não é um dogma anacrônico, como muitos tentam hoje afirmar com a bandeira de sua relativização ${ }^{190}$.

Assim, de acordo com a clássica lição de Liebman $^{191}$, coisa julgada é a qualidade da sentença que a torna imutável, alcançada em um momento em que ela não pode mais ser impugnada pelas vias ordinárias, de modo que se torna vinculante às partes e ao ordenamento, não sendo possível a nenhum juiz julgar o mesmo objeto e a mesma causa de pedir, se em litígio entre as mesmas partes.

Dessa maneira, a coisa julgada é o que garante o resultado da sentença no processo de conhecimento, a certeza para os indivíduos quanto à obtenção ou não daquele bem da vida, operando essa imutabilidade a partir do momento em que não é cabível mais qualquer recurso no processo, sendo, pois, uma estabilização para preservação de direitos, ou uma imunização geral dos efeitos da sentença ${ }^{192}$.

É certo que, incidindo a coisa julgada sobre decisão atinente a direitos disponíveis, podem as partes ajustar direitos e obrigações diferentes daquelas determinadas na sentença abarcada pela imutabilidade. Desse modo, a imutabilidade não é absoluta, pois garantidas sempre estarão a liberdade e a autonomia da vontade, sem que tal assertiva retire a carga de definitividade da coisa julgada, pois, se uma das partes não quiser modificar a situação posta pela sentença, não terá a outra como afastar-se dela ${ }^{193}$.

\footnotetext{
${ }^{190}$ V. MEDINA, Paulo Roberto de Gouvêa. "Coisa julgada: garantia constitucional”, in Revista de Processo, ano 32, v. 146, abr/2007, p. 11-31.

${ }^{191}$ LIEBMAN, Enrico. Manuale di Diritto Processuale Civile, III, $3^{\mathrm{a}}$ ed. Milão: Giuffrè, 1976, p. 159.

192 Cf. DINAMARCO, Cândido Rangel. Instituições de ... III, Op. Cit., p. 296 e 301.

${ }^{193}$ Em razão dessa possibilidade de modificação dos efeitos da decisão, é de se anotar a crítica realizada por Barbosa Moreira à teoria de Liebman, muito bem sintetizada por Talamini. Para o jurista brasileiro, a coisa julgada não se traduziria na imutabilidade dos efeitos da decisão, mas do conteúdo dessa decisão, justamente em vista de os efeitos poderem ser modificados pelas partes (TALAMINI, Eduardo. Coisa Julgada e sua Revisão, São Paulo: Revista dos Tribunais, 2005, p. 35/37).
} 
Muito importante registrar que a coisa julgada se distingue da eficácia da sentença, pois essa é um efeito da decisão que atinge a todos indiscriminadamente, ou seja, é erga omnes. Os efeitos da sentença decorrem da capacidade do Estado de decidir imperativamente ${ }^{194}$, configurando as modificações que essa sentença produz o mundo dos fatos, independentemente de quem seja diretamente atingido pela decisão ${ }^{195}$. Assim, uma decisão transitada em julgado pode afetar positiva ou negativamente a situação de pessoas estranhas ao processo, o que não significa uma eficácia expandida da coisa julgada, mas tão só um efeito reflexo da decisão, "enquanto produto final do braço judiciário do Estado" ${ }^{196}$. Todavia, esses não se submeterão, via de regra, como adiante se verá, à imutabilidade dessa sentença, justamente por constituírem terceiros na relação processual.

Para a garantia da segurança e da estabilidade a que dá relevância o sistema, o legislador criou técnicas, emoldurando o instituto. Assim, há definição sobre as condições para a sua formação, o campo de incidência e eventual revisão da coisa julgada. De igual modo, estabeleceram-se os limites da coisa julgada, tanto aqueles relativos ao objeto da decisão que será imutável (limites objetivos), como os atinentes às pessoas submetidas à imutabilidade (limites subjetivos).

Esses últimos são especialmente relevantes para a análise da coisa julgada nos processos cujo objeto são os direitos coletivos, pois reside neles uma das maiores distinções entre o processo civil clássico e o coletivo. Nesse, como se verá, é permitida - e prevista pela lei - a extensão dos efeitos da sentença a indivíduos que não participaram da relação processual, observados os requisitos que serão adiante estudados, buscando-se, com isso, uma maior efetividade do processo. Isso se mostrou necessário porque, tal qual ocorreu com a legitimidade, a adoção do modelo clássico de coisa julgada impediria a consecução dos objetivos dos processos coletivos, de maneira que teríamos um processo absolutamente ineficaz em relação a seus fins.

\footnotetext{
${ }^{194}$ Cf. DINAMARCO, Cândido Rangel. Instituições de ... III, Op. Cit., p. 207.

195 Como aduz Mesquita, os efeitos da sentença são "as alterações que esta, como qualquer ato jurídico, produz na realidade jurídica. Como tais, os efeitos da sentença podem produzir-se antes do trânsito em julgado e não só não são necessariamente imutáveis, como também podem perfeitamente beneficiar ou prejudicar terceiros" (MESQUITA, José Ignácio Botelho de. "A Coisa Julgada no Código do Consumidor", in Processo Civil: estudo em comemoração aos 20 anos de vigência, coord. TUCCI, José Rogério Cruz e, São Paulo: Saraiva, 1995, p. 142/143).

Assim, por exemplo, uma sentença que decreta o divórcio entre duas pessoas terá eficácia perante todos os cidadãos, pois aqueles indivíduos assumirão o status de divorciados em relação a todos. No entanto, isso não significa que a coisa julgada tenha se estendido erga omnes, mas tão só a eficácia da decisão.

${ }^{196}$ V. MANCUSO, Rodolfo de Camargo. Jurisdição coletiva e ...., Op. Cit., p. 250/251.
} 
Assim, mostra-se premente, em primeiro lugar, analisar os contornos subjetivos desse instituto jurídico, pois, com base neles, será possível verificar se e como a coisa julgada pode atingir terceiros não participantes do processo. Após, confrontar-se-á o sistema do processo civil clássico com aquele previsto aos processos coletivos, buscandose entender as razões das distinções, de forma a se prosseguir o estudo para se atingir o seu objetivo, antes alinhavado.

\subsection{O regime da coisa julgada no sistema processual brasileiro clássico - limites subjetivos}

No direito brasileiro, assim como na maior parte dos sistemas de civil law, o regime da coisa julgada opera de modo diferente daquele verificado nos ordenamentos de common law. Isso porque não se admite, com tanta intensidade, a extensão dos limites subjetivos da coisa julgada a terceiros, em vista da necessidade de observação do devido processo legal e do princípio do contraditório.

Os limites subjetivos da coisa julgada estão definidos, no direito brasileiro, pelo artigo 472 do Código de Processo Civil, que estabelece que "a sentença faz coisa julgada às partes entre as quais é dada, não beneficiando, nem prejudicando terceiros. Nas causas relativas ao estado de pessoa, se houverem sido citados no processo, em litisconsórcio necessário, todos os interessados, a sentença produz coisa julgada em relação a terceiros".

Consoante se verifica do citado dispositivo legal, o limite subjetivo da coisa julgada é a parte, o participante do processo, não sendo atingidos pela imutabilidade desse instituto os terceiros que não participaram do processo. Conforme explicita Scarpinella ${ }^{197}$, é a identificação da pessoa como parte ou terceiro que viabiliza a distinção entre quem estará sujeito à coisa julgada e "quem estará sujeito, apenas e tão-somente, aos efeitos da sentença ou, mais amplamente, aos efeitos de qualquer decisão jurisdicional".

${ }^{197}$ SCARPINELLA BUENO, Cassio. Partes e Terceiros ..., Op. Cit., p. 16. 
De acordo com o clássico ensinamento de Chiovenda já trazido no capítulo anterior ${ }^{198}$, parte é "aquele que demanda em seu próprio nome (ou em cujo nome é demandada) a atuação duma vontade da lei, e aquele em face de quem essa atuação é demandada". Assim, como se depreende desse ensinamento em face da norma antes mencionada, para efeitos de subsunção à coisa julgada, a identificação deve partir da situação posta em juízo, ou seja, da posição assumida pelo indivíduo dentro do processo e não na relação jurídica material.

A razão de ser da opção legislativa de limitar-se subjetivamente a coisa julgada às partes é de ordem constitucional, baseada, especialmente, nas garantias do devido processo legal, da ampla defesa, do contraditório e da inafastabilidade da tutela jurisdicional $^{199}$. Se a lei dispusesse diferente, permitir-se-ia que um terceiro, não participante do processo na condição de parte, sofresse as consequências - imutáveis - da decisão nele tomada, sem que tivesse tido a oportunidade de participar do processo, o que lhe é garantido por força do princípio do contraditório ${ }^{200}$.

Desse modo, nos termos da lei, a coisa julgada não pode prejudicar nem favorecer terceiros ${ }^{201}$. Contudo, o artigo 472 do diploma processual deve ser interpretado amplamente, pois ele não significa apenas que a imutabilidade dos efeitos não atinge os terceiros, mas que a eficácia direta da decisão (seus efeitos diretos, e não seus efeitos naturais) não pode atingir terceiros.

\footnotetext{
${ }^{198}$ CHIOVENDA, Giuseppe. Instituições de ..., Op. Cit., p. 234.

${ }^{199}$ Artigo $5^{\circ}$, incisos LIV e LV, da Constituição Federal Brasileira.

${ }^{200}$ Nesse sentido, Talamini ressalta que, se assim não fosse, "estaria sendo vedado o acesso à justiça ao terceiro, caso se lhe estendesse a coisa julgada formada em processo alheio. Depois, isso implicaria provação de bens sem o devido processo legal. Haveria ainda a frustração da garantia do contraditório: de nada adiantaria assegurar o contraditório e a ampla defesa a todos os que participam de processos e, ao mesmo tempo, impor como definitivo o resultado do processo àqueles que dele não puderam participar" (TALAMINI, Eduardo. Coisa Julgada e sua ... Op. Cit., p. 96).

Em estudo realizado em 1978, Monteleone ressaltava a tendência de ampliarem-se os limites subjetivos da coisa julgada. Ressaltou, no entanto, que tal deveria se dar apenas em casos particulares e excepcionais, de maneira que não poderia virar regra essa tendência, sob pena de ofenderem-se princípios basilares do direito processual (MONTELEONE, Girolamo A. Limiti soggettivi del giudicato civile. Padova: Cedam, 1978, p. 145).

${ }^{201}$ Neste ponto, oportuna a observação de Chiovenda, no sentido de que o afastamento de terceiros da submissão à coisa julgada é instituto advindo do direito romano: res inter alios iudicatae nullum aliis praeiudicium faciunt (fr. 7 Dig. de except. rei iudic. 44, 2); non oportet ex sententia sive iusta pro alio habita alium praegravari (fr. 21 Dig. de his qui notantur inf. 3, 2). Ressalta ele que no direito primitivo alemão, diferentemente, o juízo é "universal", prejudica todos os presentes à assembleia judiciária, ou quem quer que tenha notícia da sentença, o que explica a multiplicação, no direito alemão, dos meios de defesa para terceiros (CHIOVENDA, Giuseppe. Instituições de ..., Op. Cit., p. 414/415).
} 
É de se anotar que, geralmente, a coisa julgada opera após cognição exauriente da matéria posta sub judice, observadas as garantias constitucionais do devido processo legal e do contraditório. Todavia, há hipóteses em que tal não se verifica, como o caso da revelia, em que a coisa julgada se forma independentemente da participação do réu no processo, com possibilidade de cognição sumária pelo juiz.

No entanto, nesse caso, não há nenhuma ofensa às garantias constitucionais. Isso porque, apesar de se ressaltar, como aponta Grinover ${ }^{202}$, a necessidade de real participação das partes na atividade instrutória, já que defesa e contraditório são garantias do devido processo legal relacionadas com a igualdade e a par condicio, que legitimam o exercício da jurisdição, o que se protege por meio dessa garantia é a informação e a possibilidade de reação ${ }^{203}$. Se conferida a oportunidade e não aproveitada pela parte, não pode ela invocar violação ao princípio.

Assim, se o contraditório efetivo não foi exercido por culpa da parte revel, que não quis participar do processo, apesar de lhe ter sido conferida essa garantia, não há qualquer problema na formação da coisa julgada mediante cognição sumária, pois a oportunidade de participação houve e foi recusada pelo próprio interessado. Desse modo, ainda que revel a parte, a coisa julgada a ela se estenderá, como corolário do princípio do contraditório e em aplicação do determinado no dispositivo legal que trata do tema, pois,

${ }^{202}$ GRINOVER, Ada Pellegrini. Novas tendências do Direito Processual. Rio de Janeiro: Forense, 1990, p. 04 e 10.

203 A questão prende-se, pois, à possibilidade de participação, como a doutrina é uníssona em admitir. Esse aspecto é abordado, com a costumeira precisão, por Barbosa Moreira, que esclarece que "a garantia do contraditório significa, antes de mais nada, que a ambas as partes se hão de conceder iguais oportunidades de pleitear a produção de provas: seria manifestamente inadmissível a estruturação do procedimento por forma tal que qualquer dos litigantes ficasse impossibilitado de submeter ao juiz a indicação dos meios de prova de que pretende valer-se" (BARBOSA MOREIRA, José Carlos. "A garantia do contraditório na atividade de instrução”. In Temas de Direito Processual, $3^{a}$ série. São Paulo: Saraiva, 1984, p. 67).

Na mesma esteira, Dinamarco aduz que "contraditório é participação e sua garantia resolve-se na dupla exigência de franquear aos litigantes as oportunidades adequadas para participar e de participar ativamente o juiz também" (DINAMARCO, Cândido Rangel. Instituições de .... II, Op. Cit., p. 28), o que é referendado por Bedaque, que recorda que o contraditório impõe a "necessidade de o sistema processual infraconstitucional assegurar às partes a possibilidade da mais ampla participação na formação do convencimento do juiz" (BEDAQUE, José Roberto dos Santos. "Os elementos objetivos da demanda examinados à luz do contraditório”. In TUCCI, José Rogério Cruz e BEDAQUE, José Roberto dos Santos, coords. Causa de Pedir e pedido no Código de Processo Civil. São Paulo: RT, 2002, p. 19).

Interessante ainda apontar a lição de Chiavario, para quem "si configura quindi un' esigenza che non è soltanto di presenza, ma di possibilità di partecipazione attiva", salientando que o problema da tutela do contraditório assume importância maior e fisionomia particularmente delicada a propósito das atividades voltadas à formação do material probatório (CHIAVARIO, Mario. Processo e garanzie della persona, $2^{\mathrm{a}} \mathrm{ed}$. Milão: Giuffrè, 1982, p. 140 e 159). 
apesar de revel o réu, ele não deixou de ser parte e submeter-se, assim, ao que dispõe o artigo 472 do diploma processual.

Ocorre que os limites subjetivos da coisa julgada são de particular controvérsia, pois, em inúmeros casos, há terceiros - não participantes da demanda - com interesse jurídico sobre o objeto processual, situação que não é regulada pelo diploma processual brasileiro, tal qual ocorre, via de regra, com os sistemas de civil law ${ }^{204}$.

No entanto, mesmo diante da possibilidade de existência de terceiros interessados, preferiu o Código de Processo Civil Brasileiro, como se viu, seguindo a linha de todos os ordenamentos romano-germânicos, adotar a coisa julgada restrita aos litigantes participantes do contraditório, justamente para que fosse preservada essa garantia constitucional, "que ficaria maculada se um sujeito, sem ter gozado das oportunidades processuais inerentes à condição de parte, ficasse depois impedido de repor em discussão o preceito sentencial" 205 . Ocorre que esse dogma trazido pelo texto legal não necessitaria ser, como não é, absoluto, haja vista que há inúmeras situações que podem excepcionar a regra geral nele estabelecida.

Relativamente a esse aspecto, é de se observar que, em um primeiro momento, a limitação subjetiva da coisa julgada poderia até ser tida como inócua, porque, geralmente, os terceiros são desinteressados em relação ao que se discutiu entre outras pessoas, de modo que não precisariam estar vinculados a essa decisão. No entanto, a prática revela situação diversa ${ }^{206}$.

\footnotetext{
${ }^{204}$ Quanto a esse aspecto, Liebman já anotava a problemática da situação desses terceiros no processo, afirmando que "la regola fondamentale, che limita alle parti l'autorità della cosa giudicata, tuttora pienamente valida, risale al diritto romano: Res inter alios iudicata tertio non nocet. Ma non esaurisce il problema della situazione dei terzi di fronte alla sentenza, perché nella vita reale i rapporti tra le persone interferiscono in vario modo tra loro e la sentenza può essere indirettamente rilevante anche per i terzi" (LIEBMAN, Enrico. Manuale di Diritto ..., Op. Cit., p. 169).

Camilo Zufelato traz notícia de que a esse princípio romano também nunca foi absoluto, pois, em concomitância à adoção dele, "os jurisconsultos romanos estabeleceram um entendimento acerca das hipóteses que a ele não se submetiam, ou seja, casos excepcionais nos quais os efeitos da coisa julgada se estendiam para além de autor e réu" (ZUFELATO, Camilo. Coisa julgada coletiva..., Op. Cit., p. 78/83).

${ }^{205}$ V. DINAMARCO, Cândido Rangel. Instituições de ... III, Op. Cit., p. 317.

${ }^{206}$ Nesse diapasão, Dinamarco salienta que, da regra da limitação da coisa julgada às partes, apresentada pelo artigo 472 do Código de Processo Civil em termos aparentemente rígidos, "poderia emanar a impressão de que jamais alguém, sem ter sido parte no processo, viesse de algum modo a suportar qualquer vínculo inerente à auctoritas rei judicatae. Mas a realidade mostra que as coisas não se passam precisamente assim e o próprio art. 472 oferece uma primeira abertura para a mitigação da aparente rigidez" (DINAMARCO, Cândido Rangel. Instituições de ... III, Op. Cit., p. 318).
} 
Dessa maneira, para analisar a situação dos terceiros, faz-se necessário distinguir os diversos tipos de terceiro. Aqueles terceiros que tiverem uma indiferença jurídica em relação à matéria debatida na demanda não terão qualquer interesse em impugnar a decisão ${ }^{207}$. Portanto, não basta que o terceiro tenha interesse fático na decisão para que possa pretender impugná-la, impondo-se que seja atingido juridicamente, caso contrário não terá legitimidade e interesse de agir, pois será considerado um terceiro juridicamente desinteressado.

Assim, "grande parte do problema reside em saber quando os efeitos da sentença implicam propriamente repercussões jurídicas na esfera do terceiro e, ainda, quando esse terceiro detém legitimidade e interesse jurídico para agir em juízo em nome próprio, pretendendo pronunciamento que se contraponha aos efeitos da anterior"208.

Destarte, os terceiros que tiverem relação jurídica com a situação decidida sofrerão seus efeitos. Todavia, como regra geral, por não terem participado do processo, com as garantias do devido processo legal e do contraditório, não sofrem os efeitos da eficácia direta da decisão e não se submetem à imutabilidade de seus efeitos, imposta pelo corolário da coisa julgada. Assim, os terceiros interessados, ou seja, aqueles atingidos em sua esfera jurídica, como antes ressaltado, via de regra, podem atacar a decisão, porque terão legitimidade e interesse para tanto. No entanto, há decisões que resolvem relações jurídicas unitárias, em que é possível o litisconsórcio facultativo, como no caso de anulação de assembleia requerida por um dos sócios, em que se dicute se a autoridade da sentença se estende aos demais ${ }^{209}$.

\footnotetext{
207 "Aquele a quem a relação jurídica de direito material deduzida em juízo não traz qualquer espécie de efeito ou de consequência jurídica não tem qualquer título que legitime sua intervenção" (SCARPINELLA BUENO, Cassio. Partes e Terceiros ..., Op. Cit., p. 17/8).

${ }^{208}$ Cf. TALAMINI, Eduardo. Coisa Julgada e sua ... Op. Cit., p. 98. O autor traz exemplos de situações em que terceiros sofrem mera repercussão fática dos efeitos da sentença, como o credor de uma das partes que vê o patrimônio dela diminuir com a sucumbência, o que reduz as chances de sucesso na satisfação de seu crédito. Traz ainda hipótese em que existe a repercussão jurídica sobre a esfera do terceiro, mas, mesmo assim, ele não é titular de posição jurídica para pleitear em juízo resultado diverso, como, por exemplo, o sublocatário em face do locador. Ressalta Talamini que, "em todos esses casos, poderia parecer que os terceiros ficam vinculados à coisa julgada formada em processo alheio. Mas não. O que se tem é a impossibilidade de eles discutirem aquele resultado em juízo não pelo óbice da coisa julgada e sim por falta de legitimidade ad causam".

${ }^{209}$ Sobre o assunto, v. TUCCI, José Rogério Cruz e. Limites Subjetivos da Eficácia da Sentença e da Coisa Julgada Civil, Tese apresentada para concurso ao cargo de Professor Titular de Direito Processual Civil da Faculdade de Direito da Universidade de São Paulo, São Paulo, 2006, p. 235/241.
} 
É de se anotar que essa possibilidade só existirá a partir da verificação de que o terceiro foi prejudicado pela decisão. Isso porque, se o terceiro foi beneficiado pela sentença proferida em processo inter alios, fulmina-se o potencial interesse de agir desse favorecido pela decisão ${ }^{210}$.

Especialmente nos processos coletivos, a extensão dos limites subjetivos da coisa julgada a eventuais terceiros assume particular relevância, na medida que as questões tratadas não envolvem o direito específico daquela parte legitimada a propor a demanda, mas direitos indivisíveis de toda a sociedade indistintamente, como é o caso dos direitos difusos, ou de um determinado grupo de pessoas, na hipótese de direitos coletivos, ou ainda direitos pessoais divisíveis, que são tratados coletivamente, os chamados direitos individuais homogêneos, anteriormente estudados. Assim, por ser uma ação representativa, por meio da qual o legitimado, não necessariamente detentor do direito, como antes se viu, vai a juízo em nome de seus titulares, na qualidade de substituto processual, não faria sentido se a coisa julgada operasse sua carga de imutabilidade somente em relação ao autor da ação coletiva, pois, então, atingiria o porta-voz dos direitos e não seus titulares, não alcançando, com isso, qualquer resultado útil e não atingindo seus reais objetivos, entre eles o de solucionar conflitos de forma molecular. Por conta disso, é de rigor um tratamento diferenciado da extensão subjetiva dos limites da sentença proferida em processos coletivos ${ }^{211}$.

Como bem ressalta Mancuso, na "jurisdição coletiva", os sujeitos concernentes ao objeto litigioso não são tomados em sua singularidade, mas na sua “dimensão coletiva, atuando processualmente através de um portador judicial",

\footnotetext{
${ }^{210}$ De acordo com Tucci, "nessas condições, com o trânsito em julgado da sentença e a consequente imutabilidade do comando que dela emerge, não se vislumbra, em relação ao terceiro, qualquer violação, necessidade de modificação ou estado de incerteza atual, que possa gerar-lhe interesse processual para agir contra a coisa julgada que o favorece. Em suma: não se configurará aí a possibilidade de o terceiro pleitear em juízo o reconhecimento de direito algum" (TUCCI, José Rogério Cruz e. Limites Subjetivos ...., Op. Cit., p. 198/199).

${ }^{211}$ Consoante ensinamento de Assagra de Almeida, a revelar a importância do tema, "a coisa julgada coletiva é um dos principais institutos do direito processual coletivo, pois é por seu intermédio que se alcançará o resultado útil do processo coletivo. É por seu intermédio que ocorrerá a pacificação social de forma potencializada", ou seja, é o instituto, como antes se disse, responsável pela alteração prática e efetiva do bem da vida posto sob a análise do Judiciário, fazendo-o, no caso dos direitos coletivos, em relação a muitos indivíduos conjuntamente (ASSAGRA DE ALMEIDA, Gregório. Direito processual coletivo..., Op. Cit., p. 554).
} 
considerado um representante adequado. Assim, conclui que o discrímem entre parte e terceiro perde sua utilidade ou sua validade ${ }^{212}$.

Desse modo, para o prosseguimento deste estudo, buscar-se-á, em primeiro lugar, apontarem-se as situações existentes no direito processual clássico, no que toca à extensão dos limites subjetivos da coisa julgada aos terceiros. Para tanto, serão estudados a solidariedade, a sucessão, a substituição processual, o direito de regresso e as diversas formas de intervenção de terceiros. É certo que inúmeras outras hipóteses poderiam ser trazidas para a análise do objeto do presente estudo, mas nos concentraremos nestas, porque bastante exemplificativas da ocorrência do instituto. Após, será emoldurado o instituto da coisa julgada nos processos coletivos, de acordo com a lei posta e anotandose as modificações na lei projetada, de modo a se poder identificar as razões das disposições. Por fim, a coisa julgada coletiva será confrontada com as regras do processo clássico de extensão de seus limites e à luz da representatividade adequada, procurando apontarem-se os melhores meios para se garantir a eficácia da proteção dos direitos coletivos.

\subsubsection{Direitos e obrigações solidárias}

A solidariedade está tratada, no Direito brasileiro, pelos artigos 267 a 274 (solidariedade ativa) e 275 a 285 (solidariedade passiva) do Código Civil ${ }^{213}$. Os dispositivos legais estabelecem que qualquer credor solidário tem o direito de exigir do devedor o cumprimento da obrigação por inteiro e que o credor tem direito de exigir de qualquer dos devedores solidários a dívida inteira. Em ambos os casos, por certo, o direito daquele que não recebeu a sua parte ou que pagou integralmente quando devia só parte permanece íntegro, podendo cobrar de quem de direito o quantum que lhe é devido.

Contudo, diante dessas disposições do Código Civil, emerge questionamento no sentido da atuação da coisa julgada nos casos em que apenas um dos personagens solidariamente envolvidos exige o seu direito. Para resolver a questão, o artigo 274 do diploma civil estabelece que "o julgamento contrário a um dos credores

${ }^{212}$ V. MANCUSO, Rodolfo de Camargo. Jurisdição coletiva e ...., Op. Cit., p. 254.

213 As hipóteses específicas trazidas pelos artigos 1.314 e 1.791 do Código Civil, que se referem ao condômino e ao herdeiro, dentre outras que poderiam ser mencionadas, operam da mesma forma, pois, nesses casos, também há busca individual de um direito comum. 
solidários não atinge os demais; o julgamento favorável aproveita-lhes, a menos que se funde em exceção pessoal ao credor que o obteve". Face a esse dispositivo, resta claro que a coisa julgada não opera em relação ao terceiro na hipótese de desacolhimento do pedido, o que se insere na regra geral anteriormente exposta, visando ao resguardo das garantias constitucionais do processo e do direito subjetivo individual daquele que dele não participou.

Todavia, grande questionamento doutrinário existe quanto ao aproveitamento do julgamento favorável, se esse ocorre em relação aos efeitos da sentença ou à própria extensão da coisa julgada.

Barbosa Moreira ${ }^{214}$ ressalta que tal problema advém do fato de o litisconsórcio ativo, nesse caso, ser facultativo ${ }^{215}$. Para ele, aqui, a coisa julgada opera secundum eventum litis, ou seja, as consequências variam conforme seja a sentença de procedência ou de improcedência. Nesse caso, observa o autor, com perplexidade, que se submeteriam à coisa julgada terceiros que não participaram do processo.

Talamini $^{216}$ enfrenta a questão sob a ótica de terceiros beneficiados e prejudicados, entendendo que o que se estende aos terceiros, na hipótese de ser favorável a decisão, são os efeitos diretos da sentença, não a coisa julgada. Anota, ainda, que, sendo favorável o pedido, não podem pleitear novamente, porque não terão interesse de agir em pedir o que já foi dado em seus interesses, tal como antes se anotou em termos gerais, em relação aos terceiros.

Todavia, entende-se que o que pretendeu o artigo 274 do Código de Processo Civil é, efetivamente, estender a imutabilidade dos efeitos, gerada pela coisa julgada, a todos os credores solidários, permitindo que todos possam executar aquela obrigação reconhecida em juízo. Como muito bem aponta Cândido Dinamarco sobre o tema, essa deve ser a interpretação, pois aquele que se dispõe a figurar numa relação de direito material de forma solidária deve se submeter aos riscos da atuação daquele que foi a

${ }^{214}$ BARBOSA MOREIRA, José Carlos. "Solidariedade ativa: efeitos da sentença e coisa julgada na ação de cobrança proposta por um único credor", in Revista do Advogado, n. 84, AASP, dez/05, p. 68.

${ }^{215}$ No mesmo sentido, Eduardo Talamini ressalta que, como o litisconsórcio ativo só é obrigatório quando imposto expressamente, já que ele dificulta o exercício do direito de ação, os co-obrigados solidários podem agir sozinhos (TALAMINI, Eduardo. Coisa Julgada e sua ... Op. Cit., p. 104).

${ }^{216}$ TALAMINI, Eduardo. Coisa Julgada e sua ... Op. Cit., p. 106. 
juízo defender o que pertencia a todos ${ }^{217}$. Esse mesmo entendimento também é perfilhado por Barbosa Moreira, que anota que a parte do pleito que se refere ao direito alheio dá-se com a atuação do autor como substituto processual dos co-credores, de modo que a coisa julgada vincula tanto o substituto como o substituído ${ }^{218}$.

Como se verifica, assim, muita discussão na doutrina existe quanto à natureza do que se estende aos credores solidários terceiros na relação processual. Especialmente em vista da garantia constitucional do contraditório, a princípio, não se pode pretender a extensão subjetiva da coisa julgada, havendo sentido na tese trazida por Talamini. No entanto, como pondera Dinamarco, a assunção da solidariedade não pode ser feita sem riscos, hipótese em que operaria a força imutável da coisa julgada, o que é absolutamente pertinente.

Quando a questão da solidariedade se volta para o devedor, a decisão do processo contra apenas um dos devedores produzirá seus efeitos a todos os demais devedores solidários, porque o devedor que cumpriu a obrigação pode exigir de cada qual a parte da obrigação que lhes competia cumprir. Todavia, por serem terceiros na relação processual, os co-devedores podem defender-se integralmente.

O sistema processual tem, contudo, dispositivo apto a evitar que o devedor demandado sozinho pela dívida toda reste sem garantia do recebimento pelos demais. Trata-se do instituto do chamamento ao processo, previsto no artigo 77 Código de Processo Civil, por meio do qual os demais devedores integrarão a lide do devedor demandado com o credor, evitando que aquele arque com a obrigação por inteiro, pois, então, a coisa julgada atingirá todos os devedores.

No entanto, caso esse instituto não seja utilizado, "não se descarta o surgimento de julgados contraditórios. É possível que o devedor demandado pelo credor

\footnotetext{
${ }^{217}$ Segundo o autor, "essa extensão subjetiva da autoridade da coisa julgada não é absolutamente imune a qualquer suspeita de inconstitucionalidade, dado que colhe sujeitos que, sem terem sido partes, não tiveram acesso ao contraditório processual. Em defesa desse sistema milita o sério fundamento, vindo do direito material, de que ao dispor-se a ser credor ou devedor em solidariedade, a pessoa subordina-se às normas e aos riscos inerentes a ela (casos de solidariedade em virtude do contrato). $\mathrm{O}$ credor ou devedor que figurar na relação processual sem os demais em litisconsórcio será substituto processual dos não-participantes. Esse é um tema ainda sem suficiente maturação na doutrina ou nos tribunais" (DINAMARCO, Cândido Rangel. Instituições de ... III, Op. Cit., p. 323).

${ }^{218}$ BARBOSA MOREIRA, José Carlos. "Tutela constitucional ....”, Op. Cit., p. 219.
} 
seja condenado e, ao pretender cobrar as cotas dos demais devedores, seja também derrotado, por fundamentos que deixou de apresentar na ação contra o credor ou mesmo que apresentou mas foram rejeitados. Liebman aponta esse "inconveniente", mas considera-o, de todo modo, menos grave do que vincular os demais devedores à coisa julgada formada no processo de que não foram partes"219.

Desse modo, ao que se verifica pelo teor da lei, não se permite a extensão dos limites da coisa julgada, quando a situação é posta de forma contrária a um devedor solidário que não tenha participado da demanda.

\subsubsection{Sucessão e substituição processual}

A sucessão das partes no processo pode ocorrer por morte da pessoa física ou por incorporação ou sucessão da pessoa jurídica parte, instituto regulado no artigo 43 do Código de Processo Civil ${ }^{220}$.

Em vista disso, ocorrendo o fenômeno, é transferida ao sucessor a posição material e processual que ocupava o sucedido até então, inclusive, se já existente, a coisa julgada. Dessa forma, o sucessor não figurará como terceiro, pois entrará na relação jurídica como verdadeira parte ${ }^{221}$.

Por essa razão, na sucessão causa mortis ou na sucessão de pessoas jurídicas, a coisa julgada formada no processo atua perfeitamente, porque o sucessor adquire a condição de parte. Ressalta-se apenas que os efeitos da sentença operam nos limites da sucessão, de maneira que, por exemplo, num caso de sucessão em decorrência do falecimento da parte, os limites são os da herança, nos termos do artigo 1.792 do Código Civil.

\footnotetext{
${ }^{219}$ Cf. TALAMINI, Eduardo. Coisa Julgada e sua ... Op. Cit., p. 107.

${ }^{220} \mathrm{Na}$ definição de Clito Fornaciari, dá-se a sucessão "quando, em virtude de um ato ou um fato a que o direito empreste relevância, alguém assume a posição de outrem em uma relação jurídica. Implica, portanto, em troca de pessoas na titularidade de direitos e obrigações, que são assumidos pelo sucessor, tal qual se o antecessor nunca tivesse existido" (FORNACIARI JÚNIOR, Clito. "Sucessão processual”, in RePro, n. 24, Revista dos Tribunais, out-dez/81, p. 52).

${ }^{221}$ De acordo com Talamini, "com a sucessão são transferidas todas as posições jurídicas relativas ao objeto da sucessão (universal ou singular), inclusive as de caráter processual, como é a coisa julgada. Nesse sentido, o sucessor não detém a condição de terceiro. Ele assume as próprias posições materiais e processuais do sucedido, nos limites do objeto da sucessão" (TALAMINI, Eduardo. Coisa Julgada e sua ... Op. Cit., p. 111).
} 
Situação não tão simples ocorre na sucessão inter vivos, por meio da qual uma pessoa adquire o direito litigioso daquele que é parte no processo. Esse situação é regulada pelo artigo 42 do Código de Processo Civil, que estabelece que a legitimidade das partes não resta alterada pela alienação dos direitos em litígio. Isso porque o processo "não pode ficar a mercê de toda e qualquer mudança no plano material, vindo a ser com esta afetado. Procurando atender ao requisito da segurança da relação jurídico processual e a regra de que a entrega da prestação jurisdicional há que ser realizada o mais rápido possível, cria-se o princípio da perpetuatio legitimationis, o que nada mais é do que a estabilidade subjetiva da relação processual”, estabilidade essa que se transforma também em garantia para a parte contrária, que não fica sujeita a essa troca de parte ${ }^{222}$.

No entanto, caso haja consentimento da parte contrária, o adquirente dos direitos pode ingressar no processo como parte, sucedendo o alienante, no exato momento em que ocorre a sucessão, recebendo o processo no estado em que se encontrava, o que o impede de reavivar questões preclusas. Assim, o sucessor submete-se ao decidido naquele feito, com a carga de imutabilidade da coisa julgada, eis que parte se tornou.

Se isso não ocorrer, o alienante dos direitos pode prosseguir no processo, hipótese em que atuará como substituto processual do adquirente, que se tornou o titular da relação de direito material envolvida ${ }^{223}$. Como já se estudou no capítulo em que se tratou da legitimidade, essa substituição processual é autorizada, pela lei ou pela vontade das partes, sendo, pois, caso de legitimação extraordinária conferida pela lei ${ }^{224}$.

Nesse caso, no entanto, a incidência dos efeitos da sentença e a submissão à coisa julgada não é tão simples, já que o diretamente interessado não terá atuado em juízo por si próprio. $\mathrm{O} \S 3^{\circ}$, do artigo 42, do Código de Processo Civil, estabelece que a sentença proferida entre as partes originárias estende os seus efeitos ao adquirente ou ao cessionário.

\footnotetext{
${ }^{222}$ Cf. FORNACIARI JÚNIOR, Clito. "Sucessão ...., Op. Cit., p. 54.

${ }^{223}$ Nesse ponto, não se pode olvidar o conceito de parte de Chiovenda, anteriormente anotado, no sentido de que essa não é somente aquele que atua em juízo, mas também aquele em nome de quem se demanda. Assim, se aquele que figura agora como autor ou réu fala agora em nome do adquirente do direito, é esse e não aquele a parte

${ }^{224} \mathrm{Na}$ definição do Professor José Rogério Tucci, substituição processual é "o exercício autorizado por lei de atividade processual em nome próprio, em prol de situação subjetiva alheia” (TUCCI, José Rogério Cruz e. Limites Subjetivos da ..., Op. Cit., p. 214).
} 
Diante disso, a doutrina tradicional entende que ocorre a extensão da coisa julgada, pois o adquirente não é um terceiro, mas é o principal destinatário da norma. Liebman deixa assente essa posição, anotando que, nos casos em que a lei confere uma legitimidade extraordinária a alguém deduzir em juízo o direito de outra pessoa, os titulares desse direito restam vinculados à coisa julgada, ainda que não tenham sido chamados a participar do processo $^{225}$.

No entanto, essa posição tradicional passou a ser criticada por muitos, em face dos direitos constitucionais, já que toda a teoria que se construiu em relação aos terceiros, no sentido de que não podem ser favorecidos ou prejudicados pela coisa julgada, deixa, aqui, de ser aplicada, permitindo-se a incidência desse instituto a não participantes da relação processual.

Nesse sentido, Tucci e Talamini alertam quanto à possibilidade de infração ao devido processo legal e ao contraditório, vendo, nos princípios constitucionais, a impossibilidade de se aplicar a regra prevista na lei, já que haveria submissão à coisa julgada por indivíduos que sequer tiveram oportunidade de participar da demanda ${ }^{226}$.

Ambos os autores buscam, assim, soluções, para evitar que a coisa julgada opere sem a violação aos direitos constitucionais mencionados. José Rogério Cruz e Tucci deixa assente que, para evitar questionamentos, o adequado é a citação do adquirente como litisconsorte necessário, de maneira que ele possa ser abrangido pela coisa julgada, nos termos do artigo 472 do Código de Processo Civil.

\footnotetext{
225 "Il conferimento della legitimazione straordinaria al terzo implica infatti la conseguenza che il suo operato e la sentenza che ne consegue valgano anche per i titolari del rapporto" (LIEBMAN, Enrico. Manuale di Diritto ..., Op. Cit., p. 176/177).

Esse entendimento é referendado por Dinamarco, que salienta que "as razões que impedem a extensão dessa autoridade a terceiros não prevalecem quanto ao sucessor e ao substituído, porque deles é o interesse substancial em jogo e porque, por modos que a lei reputa idôneos, seus interesses estiveram defendidos no processo" (DINAMARCO, Cândido Rangel. Instituições de ... III, Op. Cit., p. 321).

${ }^{226}$ De acordo com Tucci, "o problema, posto dessa forma, exige que se tenha presente, mais uma vez, o postulado - até elementar, diga-se de passagem - de que não se decide a relação litigiosa, objeto central do processo, sem que os interessados se manifestem, ou melhor, sem a prévia oportunidade de defesa e participação daqueles que serão afetados pelo provimento judicial" (TUCCI, José Rogério Cruz e. Limites Subjetivos da ..., Op. Cit., p. 216).

E Talamini, no mesmo sentido, indaga "como se pode afirmar que os direitos constitucionais do substituído ao acesso à justiça, ao devido processo legal, ao contraditório e à ampla defesa não estão sendo violados quando se impede de exercê-los sob o argumento de que alguém - que não agiu em seu nome, nem com sua autorização - já atuou em juízo?” (TALAMINI, Eduardo. Coisa Julgada e sua ... Op. Cit., p. 114).
} 
Por outro lado, Talamini pauta sua crítica pela verificação da situação concreta, privilegiando a boa-fé do sucessor adquirente, e estabelece balizas para a análise do caso. Para o autor, se o terceiro - ou falso terceiro, como afirma a doutrina tradicional tinha como saber do processo e poderia nele ter intervindo, não há razão para se excluir que seja atingido pela coisa julgada. No entanto, se verificada a sua boa-fé, ou seja, se não atuou porque efetivamente não teve conhecimento do litígio, ou melhor, não poderia ter tido conhecimento dele, a imposição da coisa julgada revela-se inadequada, por força dos princípios constitucionais. Assim, o cerne da questão passa a ser o direito à informação.

Sem dúvida, a preocupação é relevante e merece atenção dos julgadores, para que se afaste a submissão de terceiros de boa-fé e totalmente desconhecedores de que sucederam alguma relação material em litígio à coisa julgada. Todavia, ela deve ser adotada com parcimônia, para também não prejudicar a parte contrária, que nada tem com a alienação. Às pessoas negociantes impõe-se a mais ampla cautela, cuja inexistência não pode ser afastada de modo simplório pelo Judiciário.

\subsubsection{Terceiros intervenientes}

Relativamente aos terceiros que detêm relação jurídica com alguma das partes, no tocante ao objeto do processo, a lei não abre qualquer exceção, não permitindo que eles sejam atingidos pela coisa julgada.

Assim, o devedor regressivo que não participou do processo, apesar de ser responsável, perante o devedor principal que participou da demanda, não fica vinculado ao nela decidido. Ele pode defender-se amplamente e produzir provas, inclusive relativas à inexistência da relação principal.

No entanto, a lei processual confere meios às partes para vincular esses terceiros, direta ou indiretamente ligados ao que se discute na demanda. Esses meios são as diversas modalidades de intervenção de terceiros, que garantem que os terceiros àquela relação processual ingressem na demanda como partes, garantindo assim a vinculação deles à coisa julgada. 
O primeiro dos institutos de intervenção de terceiros a ser analisado é o da denunciação da lide, especificado pelos artigos 70 e seguintes do Código de Processo Civil, sendo utilizado em hipóteses de direito de regresso. Ocorrendo a denunciação, forma-se uma ação incidental à ação principal entre denunciante e denunciado, que tem responsabilidade perante aquele, de modo que a matéria a ser discutida em uma eventual outra demanda o é no mesmo processo ${ }^{227}$.

Nesse caso, o denunciado adquire a condição de parte dessa relação processual incidental, podendo atuar em contraditório em sua defesa e na produção de provas, voltadas tanto para descaracterizar a obrigação principal quanto a secundária. Por tornar-se parte, submete-se à coisa julgada.

Outra hipótese de intervenção de terceiros, prevista nos artigos 77 e seguintes do Código de Processo Civil, é o chamamento ao processo, sendo essa "modalidade de intervenção de terceiros pela qual o réu pretende passem a integrar o pólo passivo da relação processual co-devedores da relação jurídica de direito material não acionados pelo autor" 228 .

Destarte, por meio do chamamento ao processo, o réu traz aos autos nova pessoa para integrar a demanda na figura de litisconsorte passivo, que se submeterá, assim, aos efeitos diretos da sentença e à força imutável da coisa julgada.

Já a oposição de terceiros, como aduzido nos artigos 56 e seguintes do diploma processual, tem lugar quando alguém pretender, no todo ou em parte, a coisa ou o direito sobre que já controvertem as partes. Desse modo, a oposição é uma ação promovida por um terceiro em face das partes originárias de um processo, por meio da qual busca o mesmo bem da vida já discutido entre eles. Como o opoente se torna parte (autor) na relação processual em face das partes originárias, submete-se ao quanto decidido na demanda, por força do disposto no artigo 472 do Código de Processo Civil.

\footnotetext{
227 De acordo com Cassio Scarpinella, “o fundamento do instituto da denunciação da lide é a economia processual, com a reunião de duas ou mais lides (ações ou demandas) em um mesmo processo, para que elas sejam resolvidas em conjunto a partir de uma mesma base procedimental" (SCARPINELLA BUENO, Cassio. Partes e Terceiros ..., Op. Cit., p. 208).

${ }^{228}$ Cf. SCARPINELLA BUENO, Cassio. Partes e Terceiros ..., Op. Cit., p. 277.
} 
A nomeação à autoria, prevista a partir do artigo 62 do Código de Ritos, é instituto que deve ser utilizado por aquele que detiver a coisa em nome alheio, sendo-lhe demandado em nome próprio, visando, portanto “à correção da ilegitimidade passiva toda vez que o réu é citado por ato que praticou em seu próprio nome por ordem de outrem, 229. Nesse caso, o réu originário é excluído da relação processual, permanecendo na lide apenas o novo réu, o nomeado, que substitui o anterior, gerando as consequências da substituição anteriormente especificadas.

Desse modo, verifica-se que, por meio de todas as modalidades de intervenção de terceiro antes mencionadas, o terceiro interveniente adquire a condição de parte ou de litisconsórcio, ainda que de uma demanda secundária ou incidental à originária. Dessa maneira, por se tornar parte, ele se submete, em todos os casos, à imutabilidade decorrente da coisa julgada, limitada essa ao objeto da intervenção.

A única modalidade de intervenção de terceiros que tem disciplina particular, quanto à extensão da coisa julgada, é a assistência, por meio da qual, de acordo com o artigo 50 do Código de Processo Civil, "pendendo uma causa entre duas ou mais pessoas, o terceiro, que tiver interesse jurídico em que a sentença seja favorável a uma delas, poderá intervir no processo para assisti-la".

$\mathrm{Na}$ assistência litisconsorcial, em que o terceiro tem interesse jurídico no deslinde da ação originária, ele assume a figura de litisconsorte da parte assistida e submete-se, assim, ao regime jurídico dela, de modo que é abrangido pela imutabilidade da sentença, por força da regra geral.

Contudo, o assistente simples não assume a condição de parte, já que ele nada pede e nada em face dele se pede. Assim, está sujeito, diferentemente do assistente litisconsorcial, à eficácia meramente reflexa do provimento jurisdicional, não de seus efeitos diretos. Diante disso, assumindo o assistente simples a condição de meramente terceiro, por não participar da relação jurídica de direito material, a princípio, estaria excluído da carga de imutabilidade da decisão ${ }^{230}$.

\footnotetext{
${ }^{229}$ SCARPINELla BUENO, Cassio. Partes e Terceiros ..., Op. Cit., p. 189.

${ }^{230}$ Nesse sentido, Cassio Scarpinella aduz que, "considerando que o assistente simples não participa da relação jurídica material subjacente à ação em que pretende intervir - tanto que nada pede para si e nada
} 
No entanto, por força do disposto no artigo 55 do Código de Processo Civil, o terceiro interveniente como assistente fica impedido de discutir a justiça da decisão, expressão que traz muita controvérsia na doutrina, o que existe por força de a lei conter conceito aberto e subjetivo, em relação ao qual não há consenso.

Desse modo, há entendimento de que a "justiça" a que a lei se referiu sejam os fundamentos de que da decisão, o que configuraria situação ainda mais rigorosa do que a coisa julgada afeita às partes, porque, para estas, imutável é apenas o dispositivo da decisão, havendo espaço para a realização do mesmo pedido, mediante a alteração da causa de pedir. Para o assistente, por a lei se referir à impossibilidade de discussão da justiça da decisão, de acordo com uma corrente de entendimento, tem-se que são imutáveis também os fundamentos da sentença.

Nesse sentido, interessante trazer a opinião de Dinamarco ${ }^{231}$, para quem “o preceito contido na sentença não se refere a uma relação jurídica de que ele seja parte, mas de algum modo será influente sobre sua situação perante o direito", daí a razão de se permitir a intervenção. No entanto, mesmo intervindo, "o terceiro não recebe a autoridade da coisa julgada material - mas os fundamentos da sentença e mesmo a conclusão desta não poderão ser mais postos em discussão por ele, dado que participou em contraditório". Assim, segundo o eminente professor, o disposto no artigo 55 do Código de Processo Civil “outra coisa não é que a eficácia preclusiva da coisa julgada, em sua projeção sobre o assistente".

Esse entendimento é referendado por Talamini ${ }^{232}$, que, expressamente, deixa assente que a lei tem razão de ser, porque, se a imutabilidade fosse circunscrita à parte dispositiva da sentença, "não haveria nenhuma concreta e útil vinculação do assistente", pois os aspectos que para ele interessam juridicamente são aqueles contidos na motivação e não na parte dispositiva. Assim, verifica-se que há expressivo entendimento doutrinário no sentido de que a coisa julgada atue com ainda mais rigor ao assistente do

contra ele é pedido -, não pode haver dúvidas de que a coisa julgada que tornará imutável os efeitos (ou, mais amplamente, o comando) da sentença a ser proferida naquela ação não o atinge. $O$ assistente simples é, por definição e inequivocamente, terceiro, a ele se aplicando a inteireza do princípio da primeira parte do art. 472 do Código de Processo Civil" (SCARPINELla BUENO, Cassio. Partes e Terceiros ..., Op. Cit., p. 159).

${ }^{231}$ V. DINAMARCO, Cândido Rangel. Instituições de ... III, Op. Cit., p. 326/327.

${ }^{232}$ TALAMINI, Eduardo. Coisa Julgada e sua ... Op. Cit., p. 118/119. 
que à própria parte, fazendo aquele vincular-se também às questões fáticas decididas na demanda.

E a jurisprudência no Brasil não destoa desse entendimento, pois é assente em determinar que a "justiça" da decisão são exatamente os fundamentos que basearam a suas razões, não se permitindo, se a questão foi decidida no processo em que se deu a assistência, que ela venha a ser rediscutida em outro processo, no qual se poderá apenas trazer pedidos e causas de pedir novas, não submetidas ao Judiciário naquele primeiro processo $^{233}$.

Isso não é absoluto, contudo, existindo espaço concedido pela lei para o assistente provar que fora impedido de atuar ampla ou livremente por atos imputáveis ao assistido ou pelo estado em que recebera o processo (incisos do artigo 55 do Código de Processo Civil). Assim, provada a boa-fé do assistente e a impossibilidade de ele atuar em contraditório pleno, de acordo com as demais garantias constitucionais, não há razão para se lhe imporem consequências mais rígidas do que aos outros terceiros, pelo que se afasta a carga coativa da coisa julgada ${ }^{234}$. Há, pois, uma presunção meramente relativa da participação na discussão dos fatos e, assim, da subsunção à coisa julgada.

Destarte, como se viu, a lei processual civil clássica não é absoluta ao retirar a carga de imutabilidade da decisão do terceiro interessado, havendo, em diversos casos, hipóteses de sua incidência em relação àqueles que não foram propriamente partes na relação jurídica processual, como é o caso da solidariedade, da substituição e da assistência.

Importante salientar que a análise da eventual atuação da coisa julgada em relação aos terceiros é importante neste estudo de processos coletivos, pois, após se tratar da extensão da coisa julgada coletiva, o que se fará a seguir, se procurará estabelecer

\footnotetext{
${ }^{233}$ Nesse sentido, o Superior Tribunal de Justiça já decidiu que o assistente "se sujeita à coisa julgada havida naquele processo, mas respeitados seus limites objetivos (art. 55, CPC)" e não pode "mais discutir a justiça da decisão que proíbe sua licenciada de utilizar marca", tendo permissão apenas de realizar pedido diverso, como "pleitear a abstenção de uso de expressão que integra sua denominação social", pois o objeto deste novo processo é diverso daquele em que se deu sua assistência (REsp 1087353/PB, Rel. Ministra NANCY ANDRIGHI, TERCEIRA TURMA, j. 17.02.09).

${ }^{234} \mathrm{O}$ Superior Tribunal de Justiça já decidiu, por exemplo, que o assistente que atuou no feito como tal pode apresentar embargos de terceiro, alegando conluio do autor e do réu naquela demanda (V. (REsp 248.288/PR, Rel. Ministro RUY ROSADO DE AGUIAR, QUARTA TURMA, j. 04.05.00).
} 
comparações com o processo civil clássico, de modo a, amparado na figura da representatividade adequada e nas previsões de extensão da coisa julgada, ser possível verificar se existem modos de se fazer do processo coletivo meio mais eficaz para a tutela dos interesses coletivos.

\subsection{O regime da coisa julgada no sistema do common law}

Como o processo coletivo de civil law tem muita influência do que dispõe o sistema de common law, far-se-á primeiro um estudo de como opera a coisa julgada nos processos coletivos nesse ordenamento, especialmente o norte-americano, para, após, apontar-se como ela atua no ordenamento brasileiro, possibilitando, com isso, a existência de mais bases para confrontação.

Importante, de início, ressaltar que, nos sistemas de common law, como regra geral, o regime da coisa julgada é diverso daquele antes relatado. Como anotou Mullenix, no relatório geral elaborado por força do XIII Congresso Mundial da Associação Internacional de Direito Processual, o regime é absolutamente complexo e depende muito da relação jurídica de direito material ${ }^{235}$. Apesar disso, buscar-se-á, a partir do ordenamento norte-americano, emoldurar o instituto, para fins de comparação com o brasileiro, objeto central deste estudo.

Importante de início anotar que, nos Estados Unidos, tal qual ocorre no Brasil, a Constituição prevê que no person shall be deprived of life, liberty, or property, without due process of law, de modo que o princípio do devido processo legal também é alçado à garantia constitucional naquele ordenamento de common law.

Contudo, diferentemente do sistema brasileiro e dos outros existentes nos ordenamentos romano-germânicos, nos Estados Unidos, a coisa julgada, nas class actions, opera, como regra geral, erga omnes, vinculando todos os membros do grupo whether favorable or not, porque a regra geral é impedir que os membros não identificados

\footnotetext{
235 "The law of res judicata in common law countries is exceedingly complex, embracing of complicated problems of issue and claim preclusion, the law of judgments and finality of judgements, doctrines of merger and bar, offensive an defensive collateral estoppel, and myriad other problems" (MULLENIX, Linda e outros. Os Processos Coletivos nos Países ....., Op. Cit., p. 287).
} 
ingressem com ações futuras. Como observa $\operatorname{Gidi}^{236}$, não há perplexidade na doutrina, pois, a princípio, não existe nada de revolucionário em uma pessoa vincular-se pelos atos de seu representante.

Assim, nas class actions processadas na forma do disposto em (b)(1) e (b)(2), após a fase de certificação, em que o magistrado define quem é membro da classe, em relação a todos eles haverá a formação de coisa julgada. Nesses casos, não há, a princípio, qualquer possibilidade de um indivíduo excluir-se dos efeitos diretos da decisão, tanto que as ações são denominadas mandatory class actions ou, em contraposição ao que adiante se verá, no opt out class action. Exatamente em vista desse fato, é imprescindível e tarefa extremamente essencial a observância rigorosa pelo juiz do preenchimento do requisito da representatividade adequada. Como ressalta Pedro Lenza ${ }^{237}$, a garantia do devido processo legal instrumentaliza-se na figura do class representatives.

Contudo, nas ações coletivas do tipo (b)(3), existe o direito de autoexclusão do interessado (right to opt out), que, quando exercido, retira desse indivíduo qualquer possibilidade de subsunção à coisa julgada formada em processo coletivo. Em vista disso, esse tipo de ação é denominada not mandatory class actions. Se o indivíduo opta por excluir-se da demanda não poderá, em eventual julgamento favorável ao grupo, aproveitar-se da decisão, devendo, para tanto, ingressar com sua ação individual autônoma, que não necessariamente terá os mesmos resultados daquela coletiva.

A questão que se coloca como ponto de especial abordagem na análise da coisa julgada em relação às not mandatory class actions toca à forma pela qual se dará ciência aos indivíduos interessados, para que exerçam seu direito de exclusão. Para tanto, prevê a Rule 23 (c)(2) que, nas ações promovidas sob os requisitos (b)(1) e (b)(2), deve o juiz realizar notificação à classe interessada. Todavia, a maior problemática se coloca no tocante às ações promovidas com fundamento em (b)(3), que tutela o que no Brasil chamamos de direitos individuais homogêneos, é a previsão legal de que se deve realizar a melhor notificação possível a seus membros, incluindo notificação individual a todos os interessados identificados, informando-os da possibilidade de exclusão.

\footnotetext{
${ }^{236}$ GIDI, Antonio. A Class Action como instrumento ...., Op. Cit., p. 271.

${ }^{237}$ LENZA, Pedro, Teoria ....., Op. Cit., p. 219.
} 
Em razão dessa disposição, já se considerou essencial nos Estados Unidos a imposição de notificação pessoal a todos os interessados identificados, como meio, principalmente, de assegurar a representatividade do legitimado e de conferir-se o direito de participação do processo, nem que fosse para, expressamente, excluir-se de seus efeitos. O problema é que a notificação pessoal é sempre muito difícil, além de extremamente custosa, tendo já essa exigência minado o prosseguimento de ações coletivas, como ocorreu com o célebre caso Eisen v. Carlisle \& Jacqelin (479 F.2d 1005), julgado em $1^{\circ}$ de maio de 1973 pela United States Court of Appeals, Second Circuit. Nesse caso, estimavase existir cerca de seis milhões de membros na classe, sendo mais de dois milhões deles facilmente identificáveis. Por conta da diversidade de regiões em que moravam, inclusive fora do país, da multiplicidade de línguas que falavam, e de outras circunstâncias dificultadoras, para a notificação pessoal de todos os interessados determinados previam-se gastos que chegariam a cento e vinte milhões de dólares. Tratava-se de um caso, como relata o julgamento, em que "the expenses of giving the notices required by amended Rule 23 and the general costs of administration of the action would exceed the amount due to the few members of the class who filed claims and the individual members of the class would get nothing", ou seja, tratava-se de um caso em que a exigência de notificação pessoal verdadeiramente minava, por razões de ordem financeira, a possibilidade de prosseguimento da ação coletiva. Em um primeiro momento, o Tribunal local determinou o prosseguimento da ação com a notificação dos membros da classe por amostragem e por edital, o que reduziu sensivelmente os custos, mas, quando do julgamento de recurso pela Corte de Apelação, em rigorosa e restritiva interpretação da Regra 23, foi negado seguimento ao processo, decidindo-se que, como havia membros identificados não notificados, a ação não poderia ter o alcance coletivo almejado ${ }^{238}$.

Todavia, esse entendimento foi minimizado e, apesar de ainda existirem decisões que impõem a notificação pessoal, adotou-se como garantia aos membros ausentes a necessidade constante da aferição da representatividade adequada pelo magistrado, não só no momento da certificação, mas durante todo o processo. Como salienta Gidi, o devido processo legal exige a representatividade adequada, mas não a notificação, de forma que ela "não é um fim em si mesma, mas um instrumento para que os membros do grupo possam controlar ou aperfeiçoar a adequação da representatividade ou

${ }^{238} \mathrm{O}$ inteiro teor do julgado pode ser obtido em http://openjurist.org/479/f2d/1005/eisen-v-carlisle-andjacquelin. 
do processo coletivo. Assim, a notificação deveria ser exigida apenas na medida em que seja necessária para assegurar tal adequação", devendo ser flexibilizado esse direito de cientificação em função da numerosidade e da dispersão do grupo, como no caso Eisen, sem que tal afronte a garantia do devido processo legal ${ }^{239}$. Diante disso, a notificação realizada de boa-fé, com o objetivo de se atingirem todos os interessados, ainda que esses todos não sejam pessoalmente notificados, deve ser considerada suficiente, interpretandose, assim, de modo não restrito a previsão da melhor notificação possível estabelecida pela $1 \mathrm{ei}^{240}$.

Para ilustrar a defesa da necessidade de flexibilização da obrigatoriedade de notificação, Gidi ressalta que o índice de pedidos de exclusão da ação coletiva é muito baixo e que essa alternativa é, muitas vezes, prejudicial ao grupo, pois, com a eventual saída de muitos de seus membros, a classe perde força, o que pode desestimular o réu a propor um acordo, porque sabe ele da existência de inúmeros interessados fora do processo, de maneira que a questão não restaria para ele definitivamente resolvida ${ }^{241}$.

Saliente-se que, nos Estados Unidos, existe a garantia a todo cidadão de ter um dia na corte para análise de seu direito (fair day in court), não se entendendo esse direito como violado pelo fato de a coisa julgada operar erga omnes, produzindo efeitos em relação aos membros ausentes. A interpretação do direito norte-americano, como ensina $\mathrm{Fiss}^{242}$, é a de que a class action é uma ação representativa, de modo que não precisaria da própria pessoa na Corte, mas que o interesse de cada indivíduo fosse representado uma vez na Corte, o que se garante com a aferição da representatividade adequada, durante todo o processo e de ofício pelo juiz. Dessa forma, uma ação futura poderia ser liminarmente rejeitada se provado restar que o interesse objeto de tutela foi completamente representado no processo anterior, não obstante o específico interessado não tenha dele participado individualmente. Isso, conclui o autor, "não significa sacrificar

${ }^{239}$ GIDI, Antonio. A Class Action como instrumento ...., Op. Cit., p. 230 e 280.

Quanto a esse aspecto, Fiss observa, com propriedade, que o propósito "não é a construção de um elo consensual entre o representante e os membros da classe, mas a obtenção da garantia de que a autonomeação está sendo feita sem abusos", "que o autor identificado será um defensor forte e efetivo para a classe" (FISS, Owen. Um novo Processo ...., Op. Cit., p. 242).

${ }^{240}$ Pedro Lenza defende a mesma posição, salientando que "o fair notice a todos os membros da classe (que possam ser identificados com razoável esforço) não pode ser tão custoso a ponto de inviabilizar o prosseguimento da ação como class action, devendo o magistrado verificar, em cada caso concreto, se preenchido está o referido requisito" (LENZA, Pedro, Teoria ....., Op. Cit., p. 222).

${ }^{241}$ GIDI, Antonio. A Class Action como instrumento...., Op. Cit., p. 297/302.

${ }^{242}$ FISS, Owen. Um novo Processo ...., Op. Cit., p. 215/232 e 240/241. 
o devido processo legal para o bem dos direitos civis, mas sim libertar o devido processo legal dos domínios de uma concepção excessivamente individualista de devido processo e reconhecer que a imparcialidade dos procedimentos em parte estimula os fins sociais que servem".

A única exceção à atuação erga omnes da coisa julgada, a não ser a possibilidade antes vista de o indivíduo excluir-se previamente da decisão (opt out), ocorre na hipótese de se provar, a posteriori, que a representatividade do legitimado não foi adequada, caso em que se permite a renovação da demanda por outro indivíduo lesado por idêntica situação fática. Esse instituto denomina-se collateral attack e, por meio dele, o juiz verifica a ausência da representação efetiva e não reconhece a vinculação do indivíduo ao decidido na demanda anterior. Quem decide quanto à ausência ou não de adequada representação não é o juiz que decidiu a primeira demanda, mas um segundo juiz, para o qual deverá o autor provar, como requisito de admissibilidade da ação, o porquê entende não ter havido a adequação. Somente se assim entendido, em um juízo prévio de admissibilidade, poderá prosseguir essa segunda demanda, até porque a questão coletiva só preclui se suficientemente litigada. Se não for, há espaço para a discussão individual, sendo essa circunstância a denominada binding effect das class actions ${ }^{243}$.

Diante disso, extrai-se que a afirmação e constante observância da representatividade adequada também é interesse do réu, de maneira que deve ele contribuir para que ela seja rigorosamente observada, eventualmente até arcando com os custos de notificações (o que, a princípio, no caso Eisen antes relatado foi realizado), que, com certeza, lhe assegurarão que a decisão será aplicável a todos os membros do grupo, sem questionamentos futuros, garantindo a necessária segurança nas relações sociais, essenciais à harmonização do ordenamento.

Exemplo da aplicação desse instituto foi o caso Gonzales v. Cassidy (474 F.2d 67), julgado em 15 de fevereiro de 1973 pela United States Court of Appeals, Fifth Circuit $^{244}$, cujo teor já foi trazido no capítulo 3 deste trabalho, quando se tratava da representatividade adequada. Trata-se de um típico caso de collateral attack, em que se decidiu, afinal, não ter havida adequada representação de Gonzales pelo autor da ação

${ }^{243}$ V. GIDI, Antonio. A Class Action como instrumento...., Op. Cit., p. 280.

${ }^{244} \mathrm{O}$ teor do julgado pode ser obtido em http://openjurist.org/474/f2d/67/gonzales-v-w-cassidy-iii. 
coletiva originária. E, com isso, abriu-se possibilidade para que ele novamente discutisse a questão.

Essa possibilidade, hoje existente e decorrente de uma evolução das class actions desde suas primeiras previsões legais, revela que o ordenamento norte-americano realmente absorve por completo o conceito de representatividade adequada ${ }^{245}$, fazendo com que todas as suas consequências sejam observadas, o que confere maior efetividade às demandas coletivas, assegurando os direitos essenciais dos indivíduos, mas, ao mesmo tempo, garantindo que as decisões tenham eficácia.

\subsection{Espécie de coisa julgada no processo coletivo brasileiro}

Após o estudo da coisa julgada nos processos coletivos de common law, este trabalho será centralizado na coisa julgada coletiva brasileira, apontando-se a lei atual e a projetada, as justificativas para a adoção de uma forma em detrimento da outra e o que a doutrina indica como novas tendências nessa matéria.

O legislador brasileiro optou por estabelecer um regime específico de coisa julgada nos processos coletivos, haja vista que a natureza desses direitos impõe uma extensão subjetiva de seus limites em demandas que sobre eles versarem, sob pena de se atentar contra a própria razão de ser dos processos coletivos, como antes se analisou. Assim, a disciplina hoje existente no Brasil faz com que a coisa julgada também se projete em relação a pessoas não participantes, na condição de parte, da relação jurídica processual, o que se denomina eficácia ultra partes da coisa julgada ${ }^{246}$.

\footnotetext{
${ }^{245}$ Nas palavras de Maximiliam Paschoal, "o texto da Regra 23 é expresso ao prever que a decisão final alcançará todos os membros do grupo, seja ela favorável ou contrária. Dessa forma, a garantia da adequada representação, juntamente com a exigência de notificações expressas, adquire relevância no cenário do processo coletivo norte-americano, já que dela dependerá a eficiência de todo o sistema da class action" (PASCHOAL, Maximiliam Fierro. A representatividade adequada ...., Op. Cit, p. 74).

${ }^{246}$ Quanto a esse aspecto, Tucci justifica a necessidade de extensão subjetiva dos limites da coisa julgada. Nesse sentido, o Professor ensina que, "quanto aos limites subjetivos da coisa julgada, o conceito unitário de consumidor traduz uma situação jurídica plurissubjetiva, na qual a relação substancial é única, mas intercorrente entre mais de um sujeito. A "afinidade" axiológica entre eficácia ultra partes e tutela dos interesses coletivos ou difusos baseia-se na relevância jurídica que a coisa julgada representa para a esfera dos interesses dos sujeitos estranhos ao processo, mas que são titulares da mesma res in iudicium deducta ou de um interesse qualificado por um vínculo de prejudicialidade-dependência" (TUCCI, José Rogério Cruz e. "Garantias Constitucionais do processo ....", Op. Cit., p. 76).
} 
A disciplina específica da coisa julgada atualmente em vigor, relativamente aos processos coletivos, é aquela constante da Lei n. 8.078/90, o Código de Defesa do Consumidor, aplicável também à Ação Civil Pública, por força do previsto em seu artigo 117, que inseriu dispositivo nesse sentido na Lei n. 7.347/85. O estabelecido na lei, pelas razões antes apontadas, afasta-se da clássica disposição do artigo 472 do diploma processual brasileiro.

Assim, os limites subjetivos da coisa julgada nos processos coletivos são regulados pelo artigo 103 do Código de Defesa do Consumidor, que estabelece coisa julgada diferenciada, conforme a espécie de direito coletivo, em sentido amplo, tratada na demanda. Por ser de fulcral importância a esse trabalho, merece ser transcrito o dispositivo:

“Art. 103. Nas ações coletivas de que trata este código, a sentença fará coisa julgada:

I - erga omnes, exceto se o pedido for julgado improcedente por insuficiência de provas, hipótese em que qualquer legitimado poderá intentar outra ação, com idêntico fundamento valendo-se de nova prova, na hipótese do inciso I do parágrafo único do art. 81;

II - ultra partes, mas limitadamente ao grupo, categoria ou classe, salvo improcedência por insuficiência de provas, nos termos do inciso anterior, quando se tratar da hipótese prevista no inciso II do parágrafo único do art. 81;

III - erga omnes, apenas no caso de procedência do pedido, para beneficiar todas as vítimas e seus sucessores, na hipótese do inciso III do parágrafo único do art. 81.

$\S 1^{\circ}$ Os efeitos da coisa julgada previstos nos incisos I e II não prejudicarão interesses e direitos individuais dos integrantes da coletividade, do grupo, categoria ou classe.

$\S 2^{\circ} \mathrm{Na}$ hipótese prevista no inciso III, em caso de improcedência do pedido, os interessados que não tiverem intervindo no processo como litisconsortes poderão propor ação de indenização a título individual.

$\S 3^{\circ}$ Os efeitos da coisa julgada de que cuida o art. 16 , combinado com o art. 13 da Lei $\mathrm{n}^{\circ}$ 7.347, de 24 de julho de 1985, não prejudicarão as ações 
de indenização por danos pessoalmente sofridos, propostas individualmente ou na forma prevista neste código, mas, se procedente o pedido, beneficiarão as vítimas e seus sucessores, que poderão proceder à liquidação e à execução, nos termos dos arts. 96 a 99.

$\S 4^{\circ}$ Aplica-se o disposto no parágrafo anterior à sentença penal condenatória".

Diante do contido na norma, observa-se que, na hipótese de direitos difusos, estabelece o seu inciso I que a coisa julgada se fará erga omnes, ou seja, atingirá todos, indistintamente, seja a sentença de procedência ou de improcedência.

Tratando-se de direitos coletivos, o inciso II do dispositivo legal dispõe que a coisa julgada se dará ultra partes, mas limitadamente ao grupo, categoria ou classe, o que é praticamente o mesmo de se afirmar a coisa julgada erga omnes, já que os únicos indivíduos que terão interesse na demanda são aqueles pertencentes ao grupo que detém, indivisivelmente, o direito.

Na hipótese de interesses individuais homogêneos, traz o inciso III, do mencionado artigo 103, a disposição de que a coisa julgada opera erga omnes, ressalvando, todavia, que tal se dá apenas no caso de procedência do pedido, para beneficiar todas as vítimas e seus sucessores. Essa coisa julgada é denominada secundum eventum litis, visto depender do resultado da demanda, constituindo uma coisa julgada in utilibus, formada só para favorecer o indivíduo, nunca para prejudicá-lo ${ }^{247}$. Por conta disso, no caso de improcedência, os interessados que não tiverem intervindo no processo na condição de litisconsortes (ou seja, aqueles que não atuaram como parte no feito) poderão propor ação a título individual, conforme prescreve o $\S 2^{\circ}$, do mesmo dispositivo legal, haja vista que a coisa julgada não os atinge. Os indivíduos membros de classes ou grupos que detenham direitos coletivos também não são atingidos por sentença de improcedência de uma ação que visa a tutelar direitos difusos ou coletivos, estando sempre assegurada a ação individual $\left(\$ 1^{\circ}\right.$ do dispositivo legal antes citado).

\footnotetext{
${ }^{247} \mathrm{O}$ disposto em relação aos direitos individuais homogêneos assemelha-se, em linhas gerais, ao que prevê a lei processual em relação ao credor solidário (artigo 274 do Código de Processo Civil). Como antes se verificou, ele só se submeterá à coisa julgada na hipótese de essa o favorecer, sendo, pois, também caso de formação da coisa julgada de acordo com o resultado da demanda, somente in utilibus.
} 
Faz-se necessário ainda ressaltar que o Código de Defesa do Consumidor prevê, expressamente, a não formação de coisa julgada na hipótese de o pedido, relativo a direitos difusos e coletivos, ser julgado improcedente por insuficiência de provas, hipótese em que qualquer legitimado poderá intentar outra ação, com idêntico fundamento, desde que se valha de prova nova, entendida não como aquela superveniente, mas como aquela não produzida no processo anterior. Parte da doutrina vislumbra, nesse dispositivo, uma autorização legal para o non liquet, que é expressamente vedado no processo individual $^{248}$.

Importante ressaltar, nos termos do que fora antes alinhavado, que se trata aqui, efetivamente, da coisa julgada, ou seja, da imutabilidade dos efeitos da sentença, da vinculação ao decidido e da impossibilidade da rediscussão de seu mérito, e não de sua eficácia generalizada, do efeito da decisão que atinge a todos indiscriminadamente, anteriormente referido.

Sendo assim, o regime da coisa julgada, nos processos coletivos, pode ser compreendido a partir do resultado da demanda, por força do disposto no artigo 103 do Código de Defesa do Consumidor. A sentença de procedência sempre beneficia a todos, fazendo coisa julgada erga omnes, com exceção apenas da hipótese de se tratar de demandas relativas a direitos coletivos, caso em que a coisa julgada é limitada ao grupo atingido, o que, de certa forma, como já aduzido, equivale à extensão indiscriminada dos efeitos da sentença, pois apenas o grupo tem interesse jurídico sobre o ali decidido.

Por outro lado, a sentença de improcedência faz coisa julgada erga omnes, salvo quando a improcedência se dá por falta de provas, em que o próprio grupo pode repropor a ação, como antes alinhavado, e no caso de a demanda versar sobre direitos individuais homogêneos, pois sempre é possível a repropositura da ação individualmente, por outro interessado, não havendo, nessa hipótese, a formação da coisa julgada em relação ao indivíduo não participante do feito originário.

\footnotetext{
${ }^{248}$ Relativamente ao processo civil tradicional, dispõe o artigo 126 do Código de Processo Civil Brasileiro que "o juiz não se exime de sentenciar ou despachar alegando lacuna ou obscuridade da lei. No julgamento da lide caber-lhe-á aplicar as normas legais; não as havendo, recorrerá à analogia, aos costumes e aos princípios gerais de direito".

No entanto, Gidi defende não se tratar, no processo coletivo, de permissão de non liquet, mas apenas de aplicação das regras do ônus da prova ao julgamento, pois o juiz não está se eximindo de julgar a lide, com o que concordamos, pois ele não está deixando de aplicar o direito para a situação fática trazida a juízo (GIDI, Antonio. Coisa julgada e litispendência em ações coletivas. São Paulo: Saraiva, 1995, p. 121).
} 


\subsubsection{Coisa julgada em processos relativos a direitos difusos e coletivos}

Diante do que se observa na norma, a coisa julgada atua, nos processos que versam sobre direitos difusos e coletivos, sempre erga omnes, em relação ao grupo, não em relação a direitos individuais conexos, de modo que a imutabilidade se estende para todos os legitimados, independentemente de terem figurado como parte na relação jurídica material.

A justificativa para a coisa julgada estender-se para todos, sem interferência do resultado da demanda, na hipótese de direitos difusos e coletivos, é, como salienta a Professora Ada Pellegrini, a natureza indivisível do direito nela tratado, de modo que não é possível ter-se decisão diferente em relação a cada indivíduo ${ }^{249}$. Desse modo, reside no próprio direito material a justificativa para a extensão indiscriminada da coisa julgada nas demandas que versem sobre esses direitos.

\subsubsection{Inconstitucionalidade da limitação da coisa julgada ao território}

Impõe-se trazer a esse estudo o que dispõe o artigo 16 da Lei $n$. 7.347/85, a Lei da Ação Civil Pública, com redação modificada em 1997, que circunscreve os limites da coisa julgada ao território ${ }^{250}$, o que deve ser entendido, como por muitos doutrinadores o é, como inconstitucional e ineficaz. Essa inconstitucionalidade advém tanto da origem do dispositivo, que nasceu como medida provisória, que não pode legislar sobre matéria processual, como, o que é ainda mais relevante para o seu estudo, da incongruência da previsão em vista da indivisibilidade dos direitos difusos e coletivos ${ }^{251}$.

\footnotetext{
${ }^{249}$ Como aduz a Professora, outra não poderia ser a solução, pois "a satisfação do interesse de um dos membros da coletividade significa inelutavelmente a satisfação dos interesses de todos os outros; assim como a negação do interesse de um indica a mesma negação para todos os outros", exemplificando o ocorrido com os casos de reparação de dano ambiental, de retirada de um produto nocivo do mercado ou de suspensão de uma publicidade enganosa. (GRINOVER, Ada Pellegrini. Os Processos Coletivos nos Países....., Op. Cit., p. 240).

250 “Art. 16. A sentença civil fará coisa julgada erga omnes, nos limites da competência territorial do órgão prolator, exceto se o pedido for julgado improcedente por insuficiência de provas, hipótese em que qualquer legitimado poderá intentar outra ação com idêntico fundamento, valendo-se de nova prova”.

${ }^{251}$ Nesse sentido, José Marcelo Vigliar aponta a inconstitucionalidade desde a origem do dispositivo, pelo que não haveria razão para modificar o tratamento dado pelo Código de Defesa do Consumidor, que é mais elaborado e tecnicamente correto. Além disso, ressalta que é impossível cogitar-se de limitar ao território a proteção de direitos difusos e coletivos, dada a indivisibilidade dos direitos (VIGLIAR, José Marcelo de Menezes. Tutela jurisdicional coletiva. São Paulo: Atlas, 1979, p. 177/182).
} 
Esse entendimento, além de desconsiderar a natureza dos direitos envolvidos, viola os próprios objetivos da ação coletiva, na medida em que não soluciona de forma molecular a questão e, mais do que isso, permite a existência de decisões contraditórias sobre o mesmo objeto, em relação a que se salienta não ser um objeto análogo ou idêntico, mas, propriamente, o mesmo objeto, o que é um absurdo.

A título de exemplificação, uma determinada propaganda enganosa não poderá o ser apenas no Estado do Mato Grosso e não no de São Paulo, assim como uma prática ambientalmente violadora por empresa atuante em todo o território nacional não poderá ser assim considerada em um Estado e não no outro ${ }^{252}$. De acordo com Fredie Didier, o dispositivo nasceu nos anos 2000, momento em que o Governo Federal era réu em diversas ações coletivas em razão de atos governamentais atinentes à abertura da economia, pelo que impôs a criação da norma, mas, sem dúvida, pelos motivos antes alinhavados, "a regra é absurda e inconstitucional", até porque comete um "erro primário" ao confundir efeitos da coisa julgada com limites territoriais de competência ${ }^{253}$.

No entanto, o Superior Tribunal de Justiça não reconhece a inconstitucionalidade do dispositivo e permanece a aplicá-lo, "malgrado seja notória a

Pedro Lenza ressalta ser a limitação tanto inconstitucional quanto inócua, pois é o pedido que definirá os limites da demanda (LENZA, Pedro, Teoria ....., Op. Cit., p. 276), o que é referendado por Arthur Carvalho (CARVALHO, Arthur Oliveira de. "A Coisa Julgada e os Limites da Competência Territorial no Processo Coletivo", in Revista Dialética de Direito Processual, n. 54, set/2007, p. 19/31).

E com igual posicionamento, Mattos conclui bem a questão, salientando que "a norma, além do vício formal, por ter resultado de conversão de medida provisória, inidônea para o regramento de matéria processual, colide com os princípios constitucionais da razoabilidade e da proporcionalidade, na medida em que desfigura, debilita, mutila e amesquinha a ação coletiva, projetada para o tratamento concentrado, em um único processo, de diversas lides, ao gerar a sua fragmentação em milhares de demandas repetitivas e desnecessárias, proporcionalmente ao número de circunscrições judiciárias existentes no País, com resultados deletérios para a economia processual e para a racionalidade do funcionamento do Poder Judiciário, transgredindo, por extensão, a eficiência que deve nortear todos os Poderes estatais" (MATTOS, Luiz Norton Baptista de. "A litispendência e a coisa julgada nas ações coletivas segundo o Código de Defesa do Consumidor e os Anteprojetos do Código Brasileiro de Processos Coletivos”, in GRINOVER, Ada Pellegrini e outros (coord.). Direito Processual Coletivo e anteprojeto de Código Brasileiro de Processos Coletivos. São Paulo: RT, 2007, p. 205).

${ }^{252}$ Quanto a esse aspecto, Teori Zavascki bem ressalta que a limitação de território importaria a "produção de uma estranha sentença, com duas qualidades: seria válida, eficaz e imutável em determinado território, mas seria válida, eficaz e mutável fora desse território", pelo que conclui que, sendo a relação jurídica única e incindível, a limitação territorial é ineficaz (ZAVASCKI, Teori Albino. Processo Coletivo ....., Op. Cit., p. $80)$.

Conforme Flávio Marcelo Gomes, permitir-se a limitação pelo território seria permitir a independência dos Estados Federativos entre si, em afronta aos princípios constitucionais brasileiros (GOMES, Flávio Marcelo, "Limites subjetivos da coisa julgada coletiva (ontem, hoje e amanhã)", Revista dos Tribunais, ano 98, v. 889, nov./2009, p. 96).

${ }^{253}$ DIDIER JÚNIOR, Fredie. "Comentário ao art. 33”, in Comentários ao Código Modelo de Processos Coletivos. Um diálogo Ibero-Americano. Salvador: Editora Juspodivm, 2009, p. 405/406. 
divergência doutrinária e jurisprudencial acerca do alcance da coisa julgada em ações civis públicas que tenham por objeto defesa dos direitos de consumidores" ${ }^{254}$. A Ministra da Corte Superior Nancy Andrighi, em artigo publicado sobre o tema, defende a aplicação do dispositivo, salientando que não se trata dos efeitos da sentença, mas apenas da coisa julgada, de modo que a sentença seria imutável apenas no território delimitado, independentemente de produzir efeitos em outros lugares ${ }^{255}$. Contudo, esse entendimento não afasta o quanto antes se expôs, pois permitirá a existência de incongruências no sistema, em relação a direitos indivisíveis, o que é inadmissível.

Nesse ponto nenhuma crítica pode ser feita ao Projeto em tramitação no Congresso Nacional, que estancou a questão, ao expressamente afastar a dependência da coisa julgada à competência territorial do órgão prolator da decisão, o que também estabelece o Código Modelo de Processos Coletivos para Ibero-América ${ }^{256}$, pois, diante da natureza dos direitos tutelados, outra não pode ser a solução.

\subsubsection{Improcedência por falta de provas e coisa julgada secundum eventum probationis}

No que toca ainda à extensão subjetiva da coisa julgada em relação aos direitos difusos e coletivos, é imprescindível ressaltar a relevância da discussão da improcedência por falta de provas, que permite a repropositura de idêntica demanda, pelo mesmo autor ou por qualquer outro legitimado, com o que se evita o conluio entre o autor e o réu, que poderia se dar com a propositura de demandas temerárias, em prejuízo definitivo dos direitos da coletividade. A lei procurou deixar assente que a coisa julgada não se

\footnotetext{
${ }^{254}$ V., nesse sentido, AgRg nos EREsp 253.589/SP, Rel. Ministro LUIZ FUX, CORTE ESPECIAL, j. 04/06/2008; AgRg no REsp 167.079/SP, Rel. Ministro LUIS FELIPE SALOMÃO, QUARTA TURMA, j. $19 / 03 / 2009$.

${ }^{255}$ V. ANDRIGHI, Fátima Nancy, "Os limites subjetivos da coisa julgada e o CDC", in SALLES, Carlos Alberto de (coord.). As grandes transformações do processo civil brasileiro: homenagem ao Professor Kazuo Watanabe. São Paulo: Quartier Latin, 2009, p. 158/159.

${ }^{256} \mathrm{O}$ artigo 33 do O Projeto de Lei n. 5.139/09 dispõe que "a sentença coletiva fará coisa julgada erga omnes, independentemente da competência territorial do órgão prolator ou do domicílio dos interessados", e o artigo 33 do Código Modelo estabelece que "a competência territorial do órgão julgador não representará limitação para a coisa julgada erga omnes".
} 
formará na hipótese de julgamento negativo por insuficiência de provas, justamente para não prejudicar os interesses do grupo ${ }^{257}$.

Anote-se que o novo processo pode ser promovido ainda que com os mesmos fundamentos, desde que o pedido se funde em nova prova, que é, então, condição de admissibilidade da nova demanda. Desse modo, deve o autor da segunda demanda trazer elementos que permitam ao magistrado aferir a novidade da prova a ser produzida logo ao início do processo. Caso se verifique que a suposta prova nova assim não o é, mas apenas um outro aspecto de uma prova já produzida e já sopesada no julgamento da causa, há de se extinguir o processo, sem apreciação do mérito, porque a nova prova é requisito de admissibilidade da segunda ação coletiva.

Houve defesa por parte da doutrina quanto à necessidade de que se constasse do dispositivo da sentença que a improcedência se dava por falta de $\operatorname{provas}^{258}$ ou que essa circunstância restasse clara pelo conteúdo da decisão ${ }^{259}$, o que, no entanto, não se mostra necessário, até porque o magistrado, muitas vezes, poderia nem saber se está julgando por faltar alguma prova, justamente por dela não ter tido conhecimento, ignorando até mesmo uma eventual colusão existente entre as partes. Assim, seria um contrassenso essa exigência, sendo bastante que se verifique a novidade da prova, como antes ressaltado ${ }^{260}$.

\footnotetext{
${ }^{257}$ Assim sustenta José Marcelo Vigliar, para quem "demandas temerárias poderiam ser ajuizadas para alcançar um julgado definitivo, contrário aos interesses que deveria defender" (VIGLIAR, José Marcelo de Menezes. Tutela jurisdicional ...., Op. Cit., p. 176).

De igual modo, Mattos aduz ter sido essa regra "inspirada no propósito de proteger os interesses da coletividade contra eventual comportamento desidioso, negligente, eivado de má-fé, do legitimado, que, em conluio com o réu, poderia deixar de trazer aos autos as provas necessárias de maneira a vedar a rediscussão da sentença de improcedência por todos os demais legitimados e membros da coletividade. Sendo muito difícil, em termos práticos, a distinção dos casos em que a insuficiência probatória é fruto da culpa ou dolo do autor da ausência efetiva da prova ou da impossibilidade da sua produção, o legislador optou por privilegiar a proteção do direito da coletividade, afastando a coisa julgada material" (MATTOS, Luiz Norton Baptista de. "A litispendência e a ....", Op. Cit., p. 201).

Também menciona a possibilidade de existência de fraudes como um dos fatores pelo qual não se pode delimitar de forma muito rigorosa os limites subjetivos da coisa julgada, o Professor uruguaio Angel Sosa (V. SOSA, Angel Ladoni. "La cosa juzgada en los procesos colectivos" in YARSHELL, Flávio Luiz, e ZANÓIDE DE MORAES, Maurício (coords.). Estudos em Homenagem à Professora Ada Pellegrini Grinover, São Paulo: DPJ, 2005, p. 457).

${ }^{258}$ V., nesse sentido, MANCUSO, Rodolfo de Camargo. Jurisdição coletiva e ...., Op. Cit., p. 318.

${ }^{259}$ V. LEONEL, Ricardo de Barros. Manual do processo coletivo. São Paulo: RT, 2002, p. 274.

${ }^{260}$ Nesse sentido, Gidi bem anota que "não deixa de estar julgando por insuficiência de provas o magistrado que, equivocadamente, pensa estar diante de todo o material probatório disponível para aquele caso concreto". Por isso, a análise deve ser substancial, sendo ônus do autor da nova ação demonstrar que a anterior assim havia sido julgada (GIDI, Antonio. Coisa julgada e ...., Op. Cit., p. 133/134).
} 
A possibilidade de propositura de uma nova demanda fundada em novas provas apenas pelo autor, na hipótese de julgamento de improcedência da primeira, sempre recebeu muitas críticas, pois não é possível verificar, nessa disposição, a garantia do equilíbrio processual e a isonomia, nem mesmo formal, entre as partes, já que se imprime um tratamento diferenciado ao autor e ao réu, que não pode valer-se de uma prova não produzida para tentar desfazer uma sentença de procedência. Para solução da problemática, o Anteprojeto de Código Brasileiro de Processos Coletivos pretendia equilibrar a situação, pois, no $\$ 6^{\circ}$ de seu artigo 13 , previa essa faculdade também ao requerido, o que é muito razoável, em termos de garantir a isonomia entre as partes, afastando a tendência de proteção excessiva ao grupo . Todavia, no Projeto em tramitação não existe essa disposição, assim como não há no Código Modelo para Ibero-América, o que é de se lamentar, pois sua ausência acaba por afrontar a própria efetividade na defesa dos direitos coletivos, que deve ser garantida de modo amplo.

Nesse ponto, importante a discussão do que seria a prova nova, sendo de se questionar se essa poderia ser uma já existente e de conhecimento do autor que não foi trazida a juízo ou se só uma prova efetivamente nova, que não existia ou que não teria podido ser apresentada. Para Pedro Lenza, tem aplicação a teoria do deduzido e do dedutível, de maneira que só uma prova efetivamente inexistente ao tempo da primeira demanda ou em relação à qual não poderia o autor tem conhecimento, daria ensejo à nova demanda. Caso assim não fosse, a coisa julgada material se formaria em relação a todos os legitimados ${ }^{261}$.

Essa teoria é discutida quando se trata de ação rescisória, prevista no artigo 275 do Código de Processo Civil, que tem como uma de suas hipóteses de cabimento o "documento novo, cuja existência ignorava [o autor], ou de que não pôde fazer uso, capaz, por si só, de lhe assegurar pronunciamento favorável". Assim, como anota Marinoni, "documento novo é aquele cuja ciência é nova ou cujo alcance é novo" 262 , não podendo esse ser documento constituído após o trânsito em julgado da decisão, pois o sentido de "obtiver documento novo", como ressalta Sérgio Rizzi, é o de "recuperar

\footnotetext{
${ }^{261}$ V. LENZA, Pedro, Teoria ....., Op. Cit., p. 286.

${ }^{262}$ V. MARINONI, Luiz Guilherme e outro. Código de Processo Civil comentado artigo por artigo, $3^{\mathrm{a}}$ tir. São Paulo: RT, 2008, p. 494/495.
} 
documento" preexistente à decisão impugnada ${ }^{263}$. No entanto, em relação à ação coletiva, pelo que se verifica da norma, possível é também a sua propositura com base em prova que sequer existia ao tempo de prolação da demanda.

Ademais, o que se vê é que, na ação coletiva, não há necessidade de rescindir o julgado diante da existência de uma prova nova, pois basta a promoção de uma nova demanda, que tem como requisito de admissibilidade a aferição dessa novidade, o que facilita sobremaneira a tutela dos direitos coletivos, evitando-se a má utilização dos processos voltados a sua defesa.

Existe dúvida na doutrina se constitui prova nova a inovação técnica, afirmando, a esse respeito, Lucon e Gabbay ${ }^{264}$ que inovações técnicas permitem concluir $a$ posteriori que a sentença anterior havia sido julgada por falta de provas, permitindo, dessa forma, a propositura de uma nova demanda. Assim, ainda que se adote o posicionamento antes externado, trata-se de prova em relação à qual era impossível o conhecimento pelo autor, pelo que a possibilidade de segunda demanda existira, sem o óbice da coisa julgada material.

O Anteprojeto de Código Brasileiro de Processos Coletivos ${ }^{265}$ previa e o Código Modelo para Ibero-América ${ }^{266}$ prevê a possibilidade expressa de nova propositura da demanda, após o conhecimento de provas novas supervenientes, mesmo que a improcedência da primeira ação não tenha se dado por falta de provas. O Projeto em tramitação, com redação diversa, estabelece disposição no mesmo sentido, prevendo uma ação revisional, após a descoberta de prova nova superveniente, idônea à mudança do resultado da demanda, mas refere-se, exclusivamente à prova técnica nova ${ }^{267}$. A previsão

\footnotetext{
${ }^{263}$ RIZZI, Sérgio. Ação Rescisória. São Paulo: Revista dos Tribunais, 1979, p. 180.

${ }^{264}$ LUCON, Paulo Henrique dos Santos e GABBAY, Daniela. "Coisa julgada secundum eventum probationis e pedido nas ações coletivas". In SALLES, Carlos Alberto de, SILVA, S. T.., NUSDEO, Ana Maria de Oliveira. Processos coletivos e tutela ambiental. Santos: EDUL - Editora Universitária Leopoldiaum, 2006, p. 174/175.

${ }^{265} \mathrm{O}$ dispositivo era previsto no $\$ 5^{\circ}$ do artigo 13 do Anteprojeto:

“ $\$ 5^{\circ}$ Mesmo na hipótese de sentença de improcedência, fundada nas provas produzidas, qualquer legitimado poderá intentar outra ação, com idêntico fundamento, no prazo de 2 (dois) anos contados do conhecimento geral da descoberta de prova nova, superveniente, que não poderia ser produzida no processo, desde que idônea para mudar seu resultado".

${ }^{266} \mathrm{O}$ artigo 33 do Código Modelo tem disposição semelhante ao do Anteprojeto, mas não traz o prazo em que a promoção da nova demanda pode se dar, referindo-se apenas a "quando surgir nova prova".

${ }^{267} \mathrm{O}$ artigo 39 estabelece que, "na hipótese de sentença de improcedência, havendo suficiência de provas produzidas, qualquer legitimado poderá intentar ação revisional, com idêntico fundamento, no prazo de um
} 
do Projeto põe fim à controvérsia existente quanto à prova nova decorrente de inovação técnica, que, de acordo com a lei posta, como se viu, já é possível, mas ainda gera controvérsias, mas não traz ao ordenamento um avanço significativo.

A previsão ampla, como constava do Anteprojeto e consta do Código Modelo iria estabelecer no Brasil a chamada coisa julgada secundum eventum probationis, segundo a qual a coisa julgada só se forma nos limites da prova produzida, como ocorre em diversos institutos processuais, como o mandado de segurança e o habeas corpus, em que sempre cabe a repropositura com base em outros elementos de prova, mesmo que formados após a propositura da primeira ação. Como define Camilo Zufelato, "a característica marcante da coisa julgada secundum probationem é exatamente a rescindibilidade da autoridade da coisa julgada mediante a existência de meio de prova superveniente, que em razão do avanço científico é capaz de alterar de modo substancial o julgamento anterior" 268 .

A adoção dessa sistemática provocaria, como ressaltam Lucon e Gabbay $^{269}$, "um rompimento com o sistema, uma ampliação do objeto visando à proteção do bem coletivo, até porque não é necessário desconstituir a sentença”, o que é bastante positivo no sentido de proteção dos direitos coletivos e não poderia ser desconsiderado pelo Projeto. Nesse caso, é importante deixar assente que não se trata, como na coisa julgada secundum eventum litis, cujo estudo aprofundado se dará a seguir, quando se tratar dos direitos individuais homogêneos, da não formação da coisa julgada em determinada hipótese, visando a impedir o trânsito em julgado material de decisões formadas em desfavor do grupo, que atinjam direitos individuais. Essa hipótese prevê a normal formação da coisa julgada, que, no entanto, fica restrita às provas que foram produzidas naquela demanda, conferindo-se a "possibilidade de permitir-se nova apreciação judicial como meio de evitar que uma decisão efetivamente injusta (é a prova nova superveniente a atestar a injustiça) se perpetue em detrimento de toda a coletividade" 270 .

ano contado do conhecimento geral da descoberta de prova técnica nova, superveniente, que não poderia ser produzida no processo, desde que idônea para mudar seu resultado".

${ }^{268}$ ZUFELATO, Camilo. Coisa julgada coletiva..., Op. Cit., p. 273/274.

${ }^{269}$ LUCON, Paulo Henrique dos Santos e GABBAY, Daniela. "Coisa julgada secundum eventum, Op. Cit., p. 161.

${ }^{270}$ V. ZUFELATO, Camilo. Coisa julgada coletiva..., Op. Cit., p. 276/277. 
Os defensores dessa modalidade de formação da coisa julgada buscam, assim, afastar a coisa julgada em hipóteses em que resta patente a injustiça da decisão, tudo tendo como justificativa a natureza dos interesses envolvidos.

A técnica assemelha-se àquela da "relativização" da coisa julgada defendida por muitos doutrinadores, "porque não se legitima que, para evitar a perenização de conflitos, se perenizem inconstitucionalidades de extrema gravidade, ou injustiças intoleráveis e manifestas", o que, de qualquer forma, devem ser casos excepcionalíssimos $^{271}$. Todavia, apesar da semelhança entre os institutos, eles não se confundem, haja vista não tratar esse da prova nova superveniente, como requisito para a aferição da injustiça, como faz a coisa julgada secundum probationem.

Importante salientar que esses casos, mesmo quando defendidos pela doutrina, devem ser sopesados em relação ao princípio constitucional da coisa julgada, anotando Zufelato que "o valor segurança jurídica continua mais forte do que nunca", pois, "se assim não fosse não seria o caso de dotar o sistema com as exceções, bastaria que o juiz de cada caso admitisse nova ação quando o entendesse justo" ${ }^{272}$. Essa hipótese geraria evidente tumulto no sistema, pois o conceito de justiça é um dos mais subjetivos, imprecisos, voláteis e parciais existentes, de maneira que a segurança restaria bastante comprometida.

A teoria da coisa julgada secundum eventum probationis é, assim, sem dúvida, um elemento criado habilmente pela doutrina para sanar possíveis irregularidades probatórias nos processos coletivos, sendo de se aplaudir a ideia, que, no entanto, pode ser desenvolvida de modo mais amplo, sem retirar a carga preclusiva da coisa julgada material, como se verá ao final desse capítulo.

\subsubsection{Coisa julgada nos processos relativos a direitos individuais homogêneos}

Consoante anteriormente se viu, a coisa julgada opera de modo diverso em relação às decisões que versem sobre direitos individuais homogêneos, não sendo

271 V. DINAMARCO, Cândido Rangel, Instituições de .... III, Op. Cit., p. 307/30. Ainda sobre a "relativização, BARBOSA MOREIRA, José Carlos. "Considerações sobre a chamada 'Relativização' da Coisa Julgada Material", in Revista Dialética de Direito Processual, n. 22, jan/2005, p. 91/111.

${ }^{272}$ Cf. ZUFELATO, Camilo. Coisa julgada coletiva..., Op. Cit., p. 300/301. 
formada na hipótese de sentença de improcedência, pois a coisa julgada atua apenas in utilibus.

Impõe-se anotar, em primeiro lugar, que, no caso de procedência do pedido, a extensão da coisa julgada se dá apenas de um benefício genérico, pois cada indivíduo deverá liquidar a sentença, provando seus prejuízos em concreto e o nexo causal desses danos com a responsabilidade genericamente reconhecida pela sentença. Assim, por exemplo, na hipótese de uma ação de reparação de danos relativa a direitos individuais homogêneos, haverá apenas o reconhecimento da responsabilidade e, assim, da obrigação de indenizar, cabendo a cada um dos efetivamente prejudicados fazer prova de seus danos diretos para ter fixada a sua indenização ${ }^{273}$.

De qualquer modo, a maior problemática da coisa julgada nas ações envolvendo direitos individuais homogêneos, com tratamento coletivo, é a sua formação no caso de improcedência do pedido, o que a diferencia da coisa julgada em processos coletivos relativos aos demais direitos. A diferença de tratamento decorre da natureza desses direitos, visto serem passíveis de divisão, de modo a serem direitos próprios de um determinado indivíduo, que não poderia, de acordo com as regras gerais sobre coisa julgada, ser prejudicado, com a imposição da imutabilidade em seu desfavor, pela atuação de terceiro. A preocupação do legislador foi, assim, com o devido processo legal e o contraditório $^{274}$, atuando a lei no sentido de permitir que cada qual discuta em juízo as particularidades de sua situação fática.

Especificamente sobre a coisa julgada coletiva, o Professor uruguaio Angel Sosa anota que a sorte de direitos tutelada exige a extensão da coisa julgada. Todavia, a limitação da coisa julgada às partes é um princípio inerente ao contraditório, de

\footnotetext{
${ }^{273}$ O Projeto em tramitação, por meio de seu artigo 23, pretende ultrapassar essa condenação genérica, pois estabelece que o juiz deve impor a satisfação da obrigação de ofício e independentemente de execução, valendo-se, para tanto, de multa e outras medidas que visem à eficácia da medida.

${ }^{274}$ O Professor Dinamarco ressalta a necessidade de proteção do contraditório, anotando que "ao contrário dos atos negociais, que criam normas particulares inter partes e em princípio vinculam exclusivamente quem as criou (autonomia da vontade), os atos de poder projetam eficácia imperativa e inevitável sobre a esfera de direitos de pessoas diferentes daquelas que os realizam. Justamente porque imperativos e inevitáveis, não se originando da vontade dos destinatários nem dependendo do concurso dela, os efeitos dos atos de poder só se consideram democraticamente legítimos quando esses sujeitos hajam tido oportunidade de participar de sua formação: participação é contraditório" (DINAMARCO, Cândido Rangel. Instituições de ... III, Op. Cit., p. $32)$.
} 
forma que vislumbra o Professor ser o sistema adotado pela legislação brasileira o mais adequado $^{275}$.

Além do contraditório, outras razões levam estudiosos a concluir pela adequação desse sistema ao ordenamento brasileiro. Mesmo aqueles que defendem a coisa julgada erga omnes nos moldes do sistema norte-americano, como Gidi, ressaltam ser a coisa julgada secundum eventum litis apta ao Brasil. De acordo com o autor, essa técnica de coisa julgada é importante em países subdesenvolvidos, sem Judiciário competente, bem aparelhado e confiável, pois a tecnologia pode ser precária, tal qual a investigação probatória, além de o juiz poder não ser suficientemente habilitado a verificar a representatividade adequada. Em vista desses aspectos, acredita ser o modelo brasileiro apto às suas necessidades ${ }^{276}$.

O sistema brasileiro, tal qual os demais ibero-americanos de civil law, tem previsão no sentido de que o indivíduo, titular de um direito individual homogêneo que esteja sendo discutido numa demanda coletiva, possa optar por nela ingressar, na qualidade de assistente litisconsorcial e, assim, submeter-se a todos os efeitos da decisão, inclusive a imutabilidade decorrente da coisa julgada. Esse critério é denominado pela doutrina como o do opt in, em oposição ao critério do opt out adotado pelos Estados Unidos, pois será submetido aos efeitos da coisa julgada aquele indivíduo que manifestar sua vontade de assim ocorrer. Como salienta Teori Zavascki, o critério do opt in realça a natureza dos direitos individuais homogêneos, como direitos subjetivos de titularidade determinada que exercem sobre eles, com exclusividade, o poder de disposição ${ }^{277}$.

Anote-se que há entendimento doutrinário no sentido de ser inconstitucional a coisa julgada secundum eventus litis, porque ela proporcionaria um desequilíbrio entre autor e réu no processo, verdadeira afronta ao princípio da isonomia, visto que jamais o requerido terá a segurança jurídica proporcionada pela coisa julgada,

\footnotetext{
${ }^{275}$ V. SOSA, Angel Ladoni. "La cosa juzgada ....", Op. Cit., p. 459/463.

Flávio Marcelo Gomes, igualmente, evoca a ofensa ao devido processo legal e ao direito de ação a extensão subjetiva da coisa julgada, pelo que também defende a atual sistemática (GOMES, Flávio Marcelo, "Limites subjetivos ...", Op. Cit., p. 91).

${ }^{276}$ V. GIDI, Antonio. A Class Action como instrumento...., Op. Cit., p. 289/290.

Pedro Lenza, analisando as características do ordenamento brasileiro, também diz ser essa a "melhor técnica a ser adotada em razão da realidade socioeconômica brasileira" (LENZA, Pedro, Teoria ......, Op. Cit., p. 261).

${ }^{277}$ V. ZAVASCKI, Teori Albino. Processo Coletivo ....., Op. Cit., p. 183.
} 
mesmo se sair vencedor na demanda coletiva. Ademais, não se pode olvidar que o regime de coisa julgada, além de trazer benefícios processuais ao autor em detrimento do réu, proporciona a ocorrência de julgamentos conflitantes e, mais do que isso, a perenização de um sentimento de incerteza, não proporcionando a segurança jurídica, garantia insculpida na Constituição Federal.

O Professor Mancuso defende a coisa julgada secundum eventum litis, ressaltando que a ação coletiva julgada improcedente cria precedente importante sobre o objeto litigioso, de modo que haverá dificuldade para o autor afastar a influência e o peso do fundamento do julgado coletivo. Além disso, ressalta o autor ser necessário tratar desigualmente os desiguais, de modo que a legitimidade extraordinária do autor (com a presença ficta na pessoa de um representante) justifica o tratamento mais benéfico do que aquele dado ao réu, que está pessoalmente presente na demanda, minimizando os prejuízos que possam ser causados por esse suposto representante ${ }^{278}$.

Além disso, a Professora Ada Pellegrini também ressalta que o réu empreenderá mais esforços na ação coletiva, de maneira que as individuais restarão com pouca chance de êxito, tendo essa sido a escolha legislativa apta a harmonizar os processos coletivos com o devido processo legal, o contraditório e a ampla defesa ${ }^{279}$.

Também em defesa da coisa julgada secundum eventum litis, Ricardo Leonel diz estar com ela garantida a garantia substancial (não meramente formal), tratando as pessoas envolvidas de acordo com sua situação concreta. Justifica ele que, "se algum preço deve ser 'pago' para o alcance da economia processual e da pacificação rápida e uniforme dos conflitos coletivos, que seja o preço menor: onera menos o sistema a sujeição do representante pela lesão a nova demanda, que a inviabilização do acesso à justiça por parte dos indivíduos interessados"280.

É de se observar, ainda, a posição externada por Camilo Zufelato, para quem, além desses aspectos, há outro que impende a adoção da coisa julgada de acordo com o resultado do processo, qual seja, a relevância social dos direitos tutelados, pois, ao

${ }^{278}$ Cf. MANCUSO, Rodolfo de Camargo. Jurisdição coletiva e ...., Op. Cit., p. 272 e 312/313.

${ }^{279}$ V. GRINOVER, Ada Pellegrini. Código Brasileiro de Defesa ...., Op. Cit., 6 a ed. Rio de Janeiro: Forense, 1999, e $8^{\text {a }}$ ed. Rio de Janeiro: Forense, 2004, p. 807/809.

${ }^{280}$ LEONEL, Ricardo de Barros. Manual do processo ..., Op. Cit., p. 262/265. 
que afirma, as espécies de interesses envolvidos "têm maior necessidade de tutela, pois dizem respeito à própria sobrevivência - ou pelo menos sobrevivência com dignidade - da coletividade", o que o leva a concluir serem infundadas quaisquer críticas ao julgado secundum eventum ${ }^{281}$.

Todavia, esse esforço perpetrado pelo réu numa ação coletiva e eventual peso dessa decisão não impede que se reconheça a existência de um tratamento sem isonomia em relação a cada uma das partes, além, é claro, do perigo de convivência de coisas julgadas contraditórias. Essa falta de isonomia é verificada tanto no plano processual quanto no plano econômico. Em que pese o réu ser, no sentido financeiro, mais pujante do que o autor coletivo, nada justifica eternizá-lo com os custos de uma demanda, no que se incluem despesas processuais e, especialmente, contratação de advogado.

Barbosa Moreira foi um dos primeiros a levantar a incongruência dessa modalidade de coisa julgada, em vista da possibilidade de coexistência de coisas julgadas contraditórias em relação a mesma pessoa, o que caracteriza como "evidentissimamente inconcebível",282.

Mattos aduz que, na coisa julgada secundum eventum litis há violação dupla do princípio da isonomia, pois, em primeiro lugar, qualquer interessado poderá ajuizar demanda individual, ensejando a emissão de julgamentos variados e antagônicos, fazendo com que indivíduos que se encontram na mesma situação recebam tratamento diferenciado. Além disso, a isonomia também seria ofendida, no tratamento conferido às partes, pois imporia um tratamento totalmente desequilibrado à figura do réu, afastando-se de um dos próprios objetivos da tutela jurisdicional ${ }^{283}$.

\footnotetext{
${ }^{281}$ V. ZUFELATO, Camilo. Coisa julgada coletiva..., Op. Cit., p. 248/249.

${ }^{282} \mathrm{O}$ autor exemplifica que, num "primeiro processo, instaurado por Tício, se julgue improcedente o pedido: os demais co-legitimados permanecem livres de propor suas ações, mas para Tício formou-se a coisa julgada sobre a declaração de validade do ato impugnado. Suponhamos, agora, que em processo posterior, instaurado por outro co-legitimado, se venha a julgar procedente o pedido, anulando-se (ou declarando-se nulo) o ato: a admitir-se que o resultado deste segundo processo se estenda a todos os membros da coletividade - inclusive, portanto, a Tício -, ter-se-á inevitavelmente, em relação a este, um conflito de coisas julgadas contraditórias" (BARBOSA MOREIRA, José Carlos. "A Ação Popular do Direito Brasileiro como instrumento de tutela jurisdicional dos chamados 'interesses difusos"'. In Temas de Direito Processual, $1^{\mathrm{a}}$ série. São Paulo: Saraiva, 1977, p. 122/123).

${ }^{283}$ Quanto esse último aspecto, ressalta o autor que "a tutela deve proteger o autor, possibilitando a satisfação do seu direito, quando procedente o pedido; e o réu, quando constatada a inexistência do direito material afirmado na inicial, dando-lhe a certeza, a segurança de que nada deve quanto ao que foi pedido e que não mais será molestado por demanda idêntica. O réu da ação coletiva vem ao processo para perder. A sua
} 
Essa questão é, pois, bastante controversa, sendo talvez aquela de maior debate quando se fala em processos coletivos no Brasil. Não cremos que a disposição seja inconstitucional, pois era necessária uma opção legislativa, entre assegurar a garantia da imutabilidade ou o contraditório. Quando foi criada a norma, escolheu-se por priorizar a defesa coletiva, o que não configura qualquer ataque à Constituição ${ }^{284}$. Contudo, também não vislumbramos ser essa, nos dias atuais, após a evolução dos processos coletivos em nosso ordenamento, tanto em debates doutrinários quanto em sua aplicação pelos Tribunais, a melhor opção, fazendo-se necessária alteração legislativa a respeito do tema da coisa julgada.

Anote-se que a lei projetada modificou um pouco a estrutura da norma. Seu artigo 33 estabelece que a sentença coletiva fará coisa julgada erga omnes, mas, antes que se imagine a adoção incondicional do instituto, verifica-se que os artigos seguintes mencionam diversas restrições, voltadas à salvaguarda dos direitos individuais, dispondo o artigo 35 do Projeto que os efeitos da coisa julgada não prejudicarão os direitos individuais dos integrantes do grupo, o que ainda revela a preocupação com o contraditório, em sua ótica individual.

Todavia, a garantia aos direitos individuais não é tão ampla como na atual lei posta, pois o $\S 1^{\circ}$ desse artigo estabelece que não serão admitidas novas demandas individuais quando aquela coletiva julgada improcedente versar sobre matéria exclusivamente de direito. Certamente esse é um avanço da legislação em relação à lei vigente, que garante indiscriminadamente o direito individual de ação, propiciando demandas repetitivas infinitas, sobre questões já decididas, mesmo que essas versem sobre matérias exclusivamente de direito antes analisadas inclusive pelas Cortes Superiores. No entanto, como adiante se verá, a legislação brasileira sobre coisa julgada nos processos coletivos poderia avançar ainda mais, no sentido de garantir a adequada e eficiente proteção dos direitos coletivos.

defesa, por mais diligente, custosa e esmerada, não vai lhe trazer grandes vantagens. (...) Forma-se, portanto, um processo em que a tutela jurisdicional somente é útil, efetiva para uma das partes; a sentença só outorga proteção a um dos litigantes" (MATTOS, Luiz Norton Baptista de. "A litispendência e a ....”, Op. Cit., p. 207).

${ }^{284}$ Como observa Jordão Violin, de início essa modalidade de coisa julgada era necessária, como um modo de se permitir a abertura da legitimidade, mas, a partir do momento em que se verifica uma verdadeira evolução do processo coletivo, ela perde sua razão de ser (VIOLIN, Jordão. Ação Coletiva Passiva..., Op. Cit., p. 55/56). 


\subsubsection{Coisa julgada na ação coletiva passiva}

Consoante se verificou no capítulo 4, entendemos já cabível e existente no ordenamento brasileiro, com base na lei posta, a ação coletiva passiva, pelo que também é imperioso o estudo da formação da coisa julgada nesse tipo de ação.

Os termos constantes do dispositivo legal do Código de Defesa do Consumidor relativos ao tema permitem supor seja aquele regime o estabelecido para as ações ativas, até porque inexiste previsão expressa, no ordenamento brasileiro, quanto ao cabimento desse tipo de ação, sendo ele apenas extraído a partir de diversas normas regentes da matéria. Ada Pellegrini defende, a princípio, a possibilidade de inversão do dispositivo que prevê a coisa julgada, de lege lata, salientando que, com isso, é mantido o espírito da lei, no sentido de resguardarem-se os interesses individuais do grupo, o princípio da razoabilidade e a defining function do juiz ${ }^{285}$.

Anote-se que o Anteprojeto de Código Brasileiro de Processos Coletivos tinha previsão exatamente nesse sentido, invertendo-se a previsão em relação às ações ativas e expressamente resguardando-se os direitos individuais.

Todavia, em que pese ser justificável a defesa da inversão da previsão legal, resta claro que, diante do que consta na lei, aquela disposição refere-se às ações ativas, pois distingue as hipóteses de procedência e improcedência da demanda, em relação a processo em que o grupo ou classe esteja no pólo ativo da ação, pelo que não pode haver aplicação imediata do disposto no Código de Defesa do Consumidor, pois a inversão não é passível de interpretação natural.

Diogo Maia defende a aplicação puramente inversa do artigo 103 do Código de Defesa do Consumidor, relativamente à coisa julgada para os direitos difusos e coletivos. Para ele, nessa hipótese, a sentença de improcedência sempre faria coisa julgada erga omnes, ao passo que a sentença de procedência só faria coisa julgada se baseada em provas que sejam suficientes para formar o convencimento do julgador ${ }^{286}$.

\footnotetext{
${ }^{285}$ V. GRINOVER, Ada Pellegrini. Código Brasileiro de Defesa ...Op. Cit., $8^{\mathrm{a}}$ ed., p. 937/938.
}

${ }^{286}$ V. MAIA, Diogo Campos Medina. Ação Coletiva ...., Op. Cit., p. 142/143. 
Contudo, essa solução foge, por completo, às regras de formação da coisa julgada em relação às provas produzidas, atentando, também, contra a regra do ônus da prova. Uma sentença só será de procedência, se o magistrado restar convencido das alegações do autor, de forma que não existe a procedência por falta de provas, porque a procedência, por si só, exige provas robustas do direito do autor, mediante a desincumbência desse de seu ônus de provar os fatos constitutivos de seu direito (artigo 333, I, do Código de Processo Civil) ${ }^{287}$.

No entanto, Ada Pellegrini logrou êxito em identificar como poderia se dar essa inversão, não se prendendo à suficiência ou não de provas, mas, sim, à suficiência ou não da defesa coletiva. Se essa não for constatada pelo juiz, não haverá formação de coisa julgada $^{288}$. Segundo Diogo Maia, na já mencionada análise da coisa julgada passiva, essa não seria a transposição pura do dispositivo legal, mas a adoção indiscriminada da coisa julgada baseada nas provas produzidas, segundo a teoria secundum probationem antes estudada. No entanto, o que se observa é que a pretensão é a de que a coisa julgada prenda-se não necessariamente às provas, mas à escorreita defesa dos interesses do grupo por seu porta-voz, ou seja, à adequada representação do grupo.

Com relação a direitos individuais homogêneos, a Professora Ada também defende a inversão do artigo 103 do Código de Defesa do Consumidor, pelo que defende que a sentença de procedência contra o litigante individual não faz coisa julgada, mantendo, pois, o sistema da coisa julgada secundum eventum litis $^{289}$.

Neste ponto, tal qual ocorre com as ações ativas, a situação encontra maior disputa doutrinária. Diogo Maia salienta não ser possível a inversão pura e simples da norma, pois a regra coletiva brasileira de que não é possível a formação de coisa julgada em desfavor do grupo nesses casos iria implicar no "afastamento integral da efetividade da ação coletiva passiva e da própria eficácia do controle jurisdicional”, o que feriria a própria Constituição Federal, haja vista que não seria aplicado o princípio da inafastabilidade do controle jurisdicional, defendido pelo autor como o que justifica o cabimento das ações

\footnotetext{
${ }^{287}$ Nesse sentido, VIOLIN, Jordão. Ação Coletiva Passiva..., Op. Cit., p. 142, em que ressalta ser descabida a existência de uma "procedência com provas suficientes" e uma "procedência por suficiência de provas".

${ }^{288}$ V. GRINOVER, Ada Pellegrini. Ações coletivas ibero-americanas..., Op. Cit., p. 8.

${ }^{289}$ Cf. GRINOVER, Ada Pellegrini. Ações coletivas ibero-americanas..., Op. Cit., p. 8.
} 
passivas. Assim, ele considera necessária ter-se como existente a coisa julgada também em desfavor do grupo colocado no pólo passivo, o que, ao que aduz, não foge das regras de direito civil, que já admite a responsabilidade civil anônima ou coletiva, como forma de desvincular a culpa individual da responsabilidade de um ente representante de uma coletividade $^{290}$.

Jordão Violin, em monografia sobre a ação passiva, salienta também a inocuidade dessa previsão, cuja sentença de procedência não vincularia qualquer membro. De acordo com ele, "defender esse caminho seria retirar da ação coletiva passiva qualquer traço de utilidade para o autor individual", pois ninguém, em sã consciência, proporia uma ação que só transitará em julgado contra seus próprios interesses ${ }^{291}$, com o que se deve concordar.

No Código Modelo de Processos Coletivos para Ibero-América, é prevista a coisa julgada passiva erga omnes para as ações coletivas passivas, resguardandose o direito dos indivíduos na hipótese de se tratar de direitos individuais homogêneos. Todavia, é interessante anotar que o parágrafo único do artigo 37 do Código Modelo estabelece que, se a ação for promovida contra sindicato, como substituto processual da categoria, a coisa julgada opera erga omnes, vinculando também os indivíduos pessoalmente. Diante dessa disposição, é de se questionar que representatividade teria o sindicato a mais do que a dos outros entes legitimados, para em relação a eles não poder se estender também a coisa julgada? A exceção não tem, pois, razão de ser.

Fredie Didier afirma a inadequação da norma, ressaltando que essa exceção foi incluída posteriormente, "após se ter percebido que, em litígios sindicais, se a coisa julgada não submeter os sindicalizados, não há qualquer sentido na ação coletiva passiva". Contudo, a mesma disposição serve para sindicatos, para cooperativas, para movimentos organizados, enfim, para todos os entes coletivos, pois nunca os indivíduos verão seriedade no comando judicial se contra eles ainda puderem se voltar individualmente.

\footnotetext{
${ }^{290}$ V. MAIA, Diogo Campos Medina. Ação Coletiva ...., Op. Cit., p. 143/146. O autor salienta, relativamente à culpa anônima, que, "se o grupo se reuniu em formato coletivo, para agir sob fundamentos de uma coletividade, valendo-se desta postura para justamente amplificar os resultados de seus atos e dificultar a sua contenção, nada mais justo que também responda sob a forma coletiva, solidariamente".

${ }^{291}$ Cf. VIOLIN, Jordão. Ação Coletiva Passiva..., Op. Cit., p. 142/143.
} 
Camilo Zufelato considerou, ao estudar o tema e diante das circunstâncias antes postas, ser imprescindível a existência de uma legislação específica sobre a questão, em vista da impossibilidade pura e simples de inversão do artigo 103 do Código de Defesa do Consumidor, porque não se pode falar em coisa julgada secundum eventum litis nesse caso. Assim, além da normatização, defende o autor a necessidade de aferição judicial da representatividade adequada, a restrição da eficácia à conduta coletiva e a impossibilidade de as ações passivas versarem sobre direitos individuais homogêneos ${ }^{292}$.

Nesse ponto, não há como não se concordar com as críticas formuladas pelos autores antes mencionados, havendo de se considerar questionável a inversão pura e simples da coisa julgada aplicável às ações ativas, por ser totalmente contrária aos objetivos do instituto. Assim, com base na lei posta, é de se rejeitar qualquer pretensão que verse sobre direitos individuais homogêneos, pois a ação passiva será inócua e, pois, não terá a eficácia que se almeja do instituto. Contudo, de lege ferenda, é possível a criação de um instituto único, que abranja as duas espécies de ações, tendo-se como base as provas produzidas no processo e o instituto da representatividade adequada.

\subsection{Análise da formação da coisa julgada em face do instituto da coisa julgada clássica, da representatividade adequada e dos objetivos do processo coletivo}

Diante do que anteriormente se expôs, pode-se concluir que a sistemática da coisa julgada, ao jamais afrontar qualquer direito individual relacionado com o objeto do processo coletivo, é contrária à própria razão de ser da tutela coletiva de direitos, pois permite a repetição de demandas, de igual natureza, em face de um mesmo réu, para garantir o exercício do direito individual de ação. Não se trata aqui de afirmar a inconstitucionalidade da norma, pois essa foi criada seguindo aos critérios de proporcionalidade entre os princípios constitucionais envolvidos, sopesando a importância desses no momento de criação da lei. O que aqui se afirma é a inocuidade da previsão em relação aos processos coletivos, considerando-se o seu atual momento evolutivo e seus objetivos, o que leva a uma redução de sua eficácia, que não tem razão de ser.

${ }^{292}$ V. ZUFELATO, Camilo. Coisa julgada coletiva..., Op. Cit., p. 482/492. 
A doutrina, como se viu, apresenta suas justificativas para manter o instituto, sempre se referindo à impossibilidade de se ofenderem os direitos fundamentais do contraditório, e à necessidade, em nome do princípio da igualdade real, de tratamento diferenciado do consumidor, por ser desigual na relação jurídica material. De acordo com essa parcela da doutrina, a situação não seria tão perversa para o demandado, pois a decisão contrária ao interesse coletivo "terá sua carga de poderoso precedente e poderá ser utilizada pelo demandado, (...) para influir no convencimento do novo juiz"293.

Realmente, a realidade atual do Brasil não permite impor a coisa julgada erga omnes, também na hipótese de improcedência de processos relativos a direitos individuais homogêneos, de forma indiscriminada, sob pena de se ferir a garantia constitucional do contraditório, pois muitos indivíduos poderão ser prejudicados, sem sequer, muitas vezes, terem ciência de que um direito seu está sub judice, o que não lhes permitira exercer o direito de opt in - ou mesmo de opt out - antes estudado. Qualquer ordenamento jurídico que tenha garantias mínimas do direito de ação ao indivíduo não pode prever a coisa julgada erga omnes sem nenhuma ressalva. Como aduz Fiss, em clássico texto sobre as ações coletivas norte-americanas, "o fato verdadeiramente perturbador em se tratando da class action é que ela cria uma situação na qual posso ser representado em processos sobre os quais nada sei, por alguém que não escolhi e nem ao menos conheço" 294 .

Contudo, não se pode considerar como absoluta a deficiência do sistema brasileiro para impedir qualquer avanço na legislação atinente aos processos coletivos. Se assim for, forçoso será reconhecer que o Brasil não tem estrutura para abrigar um instrumento processual desse gênero. Mas, a partir do momento que se permite a criação dos processos coletivos no ordenamento brasileiro, e já se vão vinte e cinco anos desde a Lei da Ação Civil Pública, não se pode mais pensar em falta de preparo e não se pode mais cogitar dos meios individuais de solução de controvérsias aptas à solução coletiva, fazendo-se de rigor, efetivamente, o mergulho no modo de ser coletivo de processo. Nas palavras do Professor Mancuso, “o bom manejo de um processo coletivo

${ }^{293}$ Relatório Geral elaborado por GRINOVER, por ocasião do XIII Congresso Mundial da Associação Internacional de Direito Processual, in GRINOVER, Ada Pellegrini e outros. Os Processos Coletivos nos Países ....., Op. Cit., p. 287.

${ }^{294}$ V. FISS, Owen. Um novo Processo ...., Op. Cit., p. 249. 
começa pela conscientização de que se trata de uma especial modalidade de acesso à Justiça, que, uma vez intentada, não comporta tergiversações em meio do percurso, nem se recomendam soluções de meio termo, que acabam induzindo um mélange com a jurisdição singular, levando que, ao fim e ao cabo, já não se saiba com qual ambiente judiciárioprocessual se está lidando" ${ }^{295}$.

E, para tanto, para que o Brasil não pare no meio do caminho dessa evolução, é imperioso que a representatividade adequada seja galgada, no ordenamento brasileiro, a princípio inerente aos processos coletivos, porque esses são, em essência, uma forma representativa de ação do indivíduo, quando esse age em sociedade e na condição de cidadão. O Anteprojeto de Código de Processos Coletivos tinha previsão desse gênero, mas é de se lamentar que semelhante disposição não tenha sido inserida no Projeto em tramitação, porque o reconhecimento do instituto como efetivo princípio, o que ainda não pode ser um mero ato formal na lei, é fundamental para que a ação coletiva possa ter a eficácia almejada, solucionando o conflito coletivo trazido ao Judiciário. Conforme a Professora Ada já ressaltava em artigo publicado ainda antes da Constituição Federal, são necessários esforços para buscar, na figura do porta-voz em juízo, as garantias de seriedade e eficiência, para que a representação dos interessados se faça de maneira adequada. "E é justamente na ótica da 'representatividade adequada' que podem ser resolvidos os problemas constitucionais da informação e dos limites subjetivos da coisa julgada, na ação coletiva"296.

Como se salientou, referentemente à coisa julgada no processo civil clássico, há várias situações em que o atingido pela decisão não é aquele que efetivamente participou do processo. Algumas hipóteses contam, certamente, com a ciência do processo por esse terceiro, que será o atingido pela decisão, mas nem sempre é assim.

$\mathrm{Na}$ hipótese de solidariedade em relação a direitos, os credores solidários, na linha do explicitado por Dinamarco, assumem o risco da espécie de relação

\footnotetext{
${ }^{295}$ MANCUSO, Rodolfo de Camargo. Jurisdição coletiva e ...., Op. Cit., p. 290, itálicos no original. ${ }^{296}$ V. GRINOVER, Ada Pellegrini. "As garantias constitucionais do processo ...”, Op. Cit., p. 24/25. Essa mesma posição é mantida posteriormente, cf. GRINOVER, Ada Pellegrini, Código Brasileiro de Defesa ..., Op. Cit., 8 ed., p. 804.
} 
jurídica por eles ostentada ${ }^{297}$, não podendo mais reclamar da conduta de um terceiro, com quem tem crédito solidário, se esse não for vencedor numa demanda judicial por ele promovida exclusivamente com vistas à defesa desse direito solidário. Ou seja, se, pela atuação de outra pessoa, em situação fática e jurídica semelhante à sua, deixar de ganhar sua pretensão, não mais poderá reclamar.

Por outro lado, na substituição, a própria lei confere o direito a outra pessoa para atuar em juízo em nome do envolvido de fato, entendendo a doutrina que se esse prejudicado tinha como saber do processo e nada fez, será submetido aos efeitos da perenização da decisão em detrimento dele, ainda que não tenha defendido em nome próprio seu direito, com as garantias constitucionais que lhe seriam inerentes.

E não se pode deixar de mencionar o instituto em que a defesa de um direito por um terceiro traga maiores consequências, que é o da figura do assistente, que terá, em demanda que não foi parte, não só a decisão (o dispositivo, que não lhe atinge diretamente) imutável, mas também a justiça da decisão, ou seja, seus fundamentos, cuja defesa foram a razão de ser de seu ingresso no processo.

Desta feita, observa-se que a atual lei posta brasileira não traz como inflexível o princípio do contraditório, permitindo, em inúmeros e justificados casos, que terceiros sejam sujeitos à imutabilidade de decisões proferidas em processos em que não foram partes, tudo de modo a tutelar de maneira adequada uma situação de direito material em que são interessados indivíduos outros além das partes ${ }^{298}$. O receio em assim se admitir em relação ao processo coletivo não tem, destarte, no império absoluto do contraditório sua razão de ser, pois esse império já não existe em nosso ordenamento, nem mesmo em relação ao processo individual tradicional.

E, tratando-se de processos coletivos, a situação deve ser ainda diferente, pois não se pode cogitar da supremacia de institutos criados para o processo

\footnotetext{
${ }^{297}$ Não se pode olvidar que isso se justifica, pois, de acordo com o artigo 265 do Código Civil, "a solidariedade não se presume; resulta da lei ou da vontade das partes", não podendo a pessoa alegar que não tinha conhecimento da solidariedade de seu direito.

${ }^{298}$ A confirmação dessa ocorrência é defendida por Camilo Zufelato, que traz, ainda, algumas outras hipóteses, previstas em leis específicas, de permissão da extensão subjetiva da coisa julgada, apontando a semelhança dessa extensão ao que ocorre em relação aos direitos coletivos (ZUFELATO, Camilo. Coisa julgada coletiva..., Op. Cit., p. 118/138 e 145/146).
} 
individual. Isso não significa o afastamento do devido processo legal ou do contraditório, mas a aplicação dessas garantias segundo uma ótica coletiva. Desse modo, como há muito salientado por Cappelletti, há a necessidade de "superar sistemas de um garantismo processual de caráter meramente individualístico", substituindo-o por um "mais novo e adequado tipo de garantismo", que se pode chamar de social ou coletivo, até porque a exigência absoluta de contraditório tornaria quase impossível a efetiva tutela das relações coletivas. O próprio autor chegou a ressaltar que, no campo do garantismo, que tinha sido sua "fé" de processualista por tantos anos, "assiste-se ao necessário movimento de uma forma nova que chamei de garantismo social ou coletivo, e que significa, exatamente, superioridade do garantismo entendido em sendo individualístico tradicional" ${ }^{\text {299. }}$.

Vigoritti há muito já deixara assente inexistir ofensa a qualquer princípio constitucional porque os representantes da classe têm capacidade de defender os interesses dela de maneira eficaz, pelo que respeitado assim estaria o devido processo legal, nessa ótica coletiva, desde que, obviamente, houvesse um rídigo controle da representatividade adequada, porque ela é a essência da ação representativa ${ }^{300}$.

A existência de um devido processo coletivo é encampada por Mancuso $^{301}$, que aduz ser "impraticável a aplicação ortodoxa e radical do contraditório e ampla defesa", havendo de se relativizar esse binômio, para que possa se acomodar "às peculiaridades e às transcendências dos conflitos de massa". Assim, defende o Professor, diante de ser impraticável a presença direta dos sujeitos envolvidos no processo, que se aceite que eles "de algum modo participam da lide coletiva, na medida em que estejam adequadamente representados por um credenciado portador". E esse devido processo coletivo tem influência direta na questão do acesso à justiça e da coisa julgada, que deixa de ser uma "intocável cláusula pétrea", "como se fosse um inabalável bloco monolítico".

Inúmeros outros autores, mesmo aqueles que defendem o atual sistema de coisa julgada coletiva, que preserva sempre os direitos subjetivos individuais, ao tratar

\footnotetext{
${ }^{299}$ V. CAPPELLETTI, Mauro. "Formações sociais e interesses .....", Op. Cit., p. 154/157.

${ }^{300}$ V. VIGORITTI, Vincenzo. Interesse collettivi e processo - la legitimazione ad agire. Milão: Giuffrè, 1979, p. 271/183. O autor deixa assente que "non esiste incompatibilità fra il precetto costituzionale e l'istituto della class action, ma sopratutto nel sendo che non vi sai violazione del due process quando la disciplina positiva adotatta 'fairly insures the protection of the interests of absent parties who are to be bound by it"”.

${ }^{301}$ MANCUSO, Rodolfo de Camargo. Jurisdição coletiva e ...., Op. Cit., p. 284 e 300.
} 
dos processos coletivos, ressaltam a necessidade de ver-se com outros olhos o devido processo legal. Esse não se prende, propriamente, às garantias do contraditório e da ampla defesa, que devem ser "revisitadas"302, e deve, tal qual todos os princípios constitucionais, ser sopesado em relação aos demais princípios, seguindo critérios de proporcionalidade ${ }^{303}$.

Não se pode olvidar que nenhum princípio é auto-aplicável, pois, conforme lição de Larenz ${ }^{304}$, são ideias ou diretrizes, que dependem de uma norma constitucional, da legislação ou da jurisprudência. É certo que "o ideal de plena concordância valorativa de todas as normas e resoluções não pode realizar-se já, pelo facto de que as regras legais surgiram em diferentes graus de evolução histórica e uma valoração distinta num sector parcelar do ordenamento jurídico não pode ter de imediato repercussão noutro sector parcelar". Assim, existe possibilidade e esta é ocorrente em qualquer ordenamento, de conflito entre princípios, que devem ser solucionados com base na proporcionalidade $^{305}$.

E a solução para ver-se efetivado o princípio do devido processo legal coletivo em face do da segurança jurídica reside, sem dúvida, na representatividade adequada, que, como se viu, apesar de ser consideravelmente aplicada em relação à legitimidade, é esquecida quando se trata de coisa julgada, instituto processual garantidor da necessária segurança.

É certo que os sistemas de coisa julgada condicional contidos na lei atual, como a coisa julgada secundum eventum litis e a não formação da coisa julgada quando a improcedência da ação se dá por falta de provas foram extremamente importantes

\footnotetext{
${ }^{302}$ Para Cássio Scarpinella, "a concepção do devido processo legal, do contraditório, da formação da coisa julgada exclusivamente entre partes, deve sofrer mitigações - ou o que é preferível, uma verdadeira revisitação - a partir de novas exigências criadas para o direito processual diante da mutação do direito material" (SCARPINELLA BUENO, Cassio. "As class actions norte-americanas e ...", Op. Cit., p. 100). Camilo Zufelato aduz que o contraditório e a ampla defesa têm aplicabilidade, mas, "em razão das características ínsitas no bem jurídico tutelado e na forma como as ações se desenvolvem, o princípio [do devido processo legal] ganha conotação própria no âmbito da tutela jurisdicional coletiva" (ZUFELATO, Camilo. Coisa julgada coletiva..., Op. Cit., p. 163/175).

${ }^{303}$ Diogo Maia anota que "o devido processo legal e seus corolários devem atuar para garantir que os atos processuais sejam efetivados de forma proporcional ao bem jurídico em discussão" (MAIA, Diogo Campos Medina. Ação Coletiva ...., Op. Cit., p. 99).

${ }^{304}$ LARENZ, Karl, Metodologia da ciência do Direito. Tradução de José Lamego, Lisboa, Fundação Calouste Gulbenkian, 1997, p. 599 e 695.

${ }^{305}$ Sobre o princípio da proporcionalidade, v., dentre outros, CANOTILHO, J.J. Gomes. Direito Constitucional ...., Op. Cit.; BONAVIDES, Paulo, Curso de Direito Constitucional, 12 $2^{\mathrm{a}}$ ed., São Paulo, Malheiros, 2002; STUMM, Raquel Denize, Princípio da proporcionalidade no Direito Constitucional Brasileiro, São Paulo, Livraria dos Advogados, 1995.
} 
para que se pudesse ter confiança no processo coletivo. De igual modo, é teoria inteligente e prática a coisa julgada secundum probationem. No entanto, todas essas teorias parecem esquecer da natureza da ação coletiva, que é representativa, de modo a estar na representatividade adequada a solução para a coisa julgada coletiva operar como instrumento hábil a trazer um maior grau de eficácia ao processo coletivo, garantindo a necessária segurança, sem afastar a índole coletiva do devido processo legal.

Há, obviamente, aqueles que negam qualquer adaptação do processo civil clássico às concepções coletivas, como o faz Gomes, para quem a representatividade adequada, tal qual a não formação da coisa julgada por falta de provas são "subterfúgios" inspirados no direito norte-americano, que não se aplicam ao direito brasileiro, sendo necessário, como ressalta esse autor, acostumar-se com o risco perene do réu na ação coletiva e não tentar criar "remendos" baseados no direito estrangeiro ${ }^{306}$. Todavia, esquece o autor que a ação coletiva é instrumento de inspiração norte-americana, de maneira que não se pode pretender daquele ordenamento nada se importar.

Desta feita, como sempre com precisão ensina Owen Fiss, em lição que é digna de ser transcrita, "os propósitos sociais da class action podem, indubitavelmente, justificar essa estranha forma de representação, mas seria um erro ignorar ou negar sua própria singularidade e o fato de que ela opõe-se aos valores individualistas que permeiam intensamente nosso sistema jurídico. (...) Os valores individualistas que a class action questiona estão, todos, presentes no direito norte-americano, talvez no direito de todos os países, e, por bem ou por mal, sempre exercerão uma influência contendora sobre a grande tentação dos reformadores sociais no sentido de criarem instrumentos que possam melhor servir a seus fins",307.

No entanto, é nessa "estranha forma de representação" afirmada por Fiss que está uma solução plausível e possível para a coisa julgada. Não há como se ignorar que o porta-voz do grupo age em juízo em nome desse grupo e de todos os indivíduos envolvidos, de maneira que, se reconhecida essa sua condição, não há porque, sem uma justificativa plausível aferida no caso concreto, permitir-se que alguém desse grupo questione a decisão, somente porque contrária a seus interesses. A parte ideológica,

\footnotetext{
${ }^{306}$ GOMES, Flávio Marcelo, “Limites subjetivos da ...”, Op. Cit., p. 78/104.

${ }^{307}$ FISS, Owen. Um novo Processo ...., Op. Cit., p. 249.
} 
o porta-voz do grupo, como ressalta Cappelletti ${ }^{308}$, se adequadamente representativo, deve ser autorizado a agir por toda a classe, incluindo os membros ausentes, que não foram propriamente ouvidos, no sentido físico, direto e literal da palavra. E essa atuação insta ser completa e vinculante.

Não se pode admitir a situação atualmente verificada e bem salientada Márcio Flávio Leal, de a representatividade adequada do grupo só ser considerada na hipótese de decisão favorável à classe. Quando da improcedência da ação, a doutrina lembra "subitamente do indivíduo até então idealizado" e percebe que ele não participou do processo. Assim, o "representante, como um passe de mágica”, perde "sua aura de adequado, em nome do devido processo legal de inspiração no processo civil clássico que tanto se renegou",309.

É certo, assim, que a representatividade adequada garante o devido processo legal coletivo, “com a inafastabilidade da jurisdição, do contraditório e da ampla defesa", sendo esse instituto pressuposto lógico do devido processo legal no plano coletivo, assegurando que a coisa julgada possa operar erga omnes ${ }^{310}$.

Desta feita, se não houver qualquer prova de que a atividade desse representante foi inadequada, seja porque não apresentou todas as alegações necessárias, seja porque não trouxe aos autos as provas úteis para o julgamento, seja porque atuou em conluio com a parte contrária, enfim, inexistente quaisquer dos motivos que fundamentam a lei e a doutrina para hoje afastar a coisa julgada erga omnes, não há razão para que ela assim não opere. Se esse for o sistema adotado pelo Brasil, é inócua a tamanha distinção entre as várias espécies de coisa julgada ou a restrição dessa às provas produzidas, pois, tudo isso estará englobado pela coisa julgada condicionada exclusivamente à adequação da representação.

E essa situação não fere o contraditório além dos limites da coisa julgada na solidariedade ativa ou na assistência simples, em que o assistente não pode mais questionar a justiça da decisão. Como ocorre com a assistência, há uma presunção relativa

${ }^{308}$ CAPPELLETTI, Mauro. The judicial process ...., Op. Cit., p. 302/303.

${ }^{309}$ LEAL, Márcio Flávio Mafra, "Anteprojeto de Código ....", Op. Cit., p. 73.

310 V. LEONEL, Ricardo de Barros. Manual do processo ..., Op. Cit., p. 261. No mesmo sentido ZUFELATO, Camilo. Coisa julgada coletiva ..., Op. Cit., p. 175/176. 
da veracidade de que ele foi bem representado (porque, para tanto, deverá haver decisão expressa quanto à questão), que é desfeita com a prova de que ele não pode participar da instrução, que o autor não trouxe todos os fatos relevantes ao processo, hipótese em que, como o collateral attack do direito norte-americano, pode o interessado promover nova ação, sem necessidade, nem mesmo, de rescindir-se a primeira sentença, pois a coisa julgada não terá se formado, consoante, no juízo de admissibilidade de uma segunda ação, será reconhecido.

Certamente, a adoção dessa sistemática impõe a mudança legislativa, mas o ordenamento brasileiro não deve temer essa opção. É certo que inúmeras precauções devem ser tomadas, como a observância rigorosa da adequação do representante, durante toda a tramitação do processo, o que também será de interesse absoluto do réu, pois saberá que, com isso, terá sua segurança preservada.

Outrossim, a informação é requisito necessário, para que os interessados possam intervir no feito, se considerarem útil para si próprios ou para o grupo. Para tanto, não vislumbramos necessária a notificação individual, pois, além de impraticável economicamente, como já demonstrou a Justiça estadunidense, o Brasil já revelou ser ela desnecessária. Isso porque não é possível conhecer uma pessoa sequer que não tivesse tido ciência da possibilidade de ingresso de ações contra instituições financeiras por conta de erros de atualização monetária de planos econômicos ou de ações contra empresas de telefonia em razão da assinatura básica, dentre tantas outras existentes. As filas junto aos distribuidores, às vésperas do prazo prescricional dessas ações, revelam que a falta de informação não é justificativa para não de adotar o sistema pelo Brasil. E não se pode olvidar que todas as ações contarão com a participação do Ministério Público como fiscal da lei, o que também é uma garantia de obediência aos princípios.

Além disso, não se pode olvidar que pode ser do interesse do próprio réu ampliar a informação, quiçá arcando com os custos de notificações pessoais, para ver, definitivamente, estanque a questão, sem contar com o já projetado Sistema Único de Ações Coletivas ${ }^{311}$, que permitirá uma consulta pública por qualquer interessado das medidas em tramitação no Judiciário.

\footnotetext{
${ }^{311}$ Previsto nos artigos 55 e 56 do Projeto em tramitação no Congresso Nacional.
} 
Portanto, acreditamos que a melhor solução é a extensão da coisa julgada a todos os interessados, em relação às questões comuns trazidas a juízo, sendo dada a esses a oportunidade, como ocorre no direito norte-americano, de promover uma nova ação, sem necessidade de rescisão da primeira, se provar a ausência de representatividade adequada, o que pode se dar pela simples ausência de produção de uma prova ou de alegação de um fundamento importante para a defesa do grupo. Essa previsão tornaria mais simples e eficaz o processo coletivo, sem que se atentasse contra nenhuma garantia constitucional, especialmente o devido processo legal, aqui aplicado em uma ótica coletiva, que caminhará ao lado do princípio da segurança jurídica, tão necessário para a harmonização do ordenamento. 


\section{CONSIDERAÇÕES FINAIS}

Consoante de início se referiu, o objetivo central do presente trabalho foi a análise do instituto da representatividade adequada nos processos coletivos, de modo a se contribuir para majorar a eficácia de proteção dos direitos coletivos amplamente considerados.

Os direitos coletivos tiveram seu estudo iniciado a partir do momento em que as pessoas tomaram consciência de sua condição de indivíduos inseridos na comunidade em que vivem, ou seja, a partir da conscientização pelo homem de que ele não mais poderia ser um ente isolado de seu meio, mas, sim, deveria com ele interagir, buscando na sociedade massificada e junto aos outros em mesma situação amparo para seus problemas e força para suas reivindicações, sejam essas em face de outras pessoas, de empresas privadas ou do Poder Público. Assim, absorvida essa consciência de classe pelos indivíduos, o que começou a ocorrer em meados do século XVIII, nos países de ordenamento de common law, teve início o desenvolvimento dos processos coletivos, que chegaram a um considerável nível de maturação somente no século XX.

Desta feita, é novo o debate sobre os processos coletivos, especialmente no Brasil, visto seu estudo ter aqui se desenvolvido com mais rigor há pouco mais de três décadas, momento em que começaram a surgir as leis que primeiro trataram do tema, como aquelas que criaram a ação popular, a ação civil pública e, posteriormente, a ação para defesa do consumidor. Referidas leis buscaram também, após o advento da Constituição Federal de 1988, apoio na carta constitucional para seu desenvolvimento, pois essa previu uma série de direitos coletivos como garantias ao cidadão, bem como meios para sua proteção, estabelecendo, pode-se dizer de modo definitivo, a proteção dos direitos coletivos no ordenamento brasileiro. Todavia, a evolução dos processos coletivos não se encerrou, encontrando-se a sociedade em um momento de debates sobre alterações legislativas e meios processuais de se fazer ainda mais eficaz a proteção dos direitos coletivos, o que indica a relevância do tema.

Essas são as razões de cunho geral que justificaram esse estudo, centrado no instituto da representatividade adequada, porque ele é minimamente 
considerado no ordenamento brasileiro, sendo, até a atualidade, alijado das leis que tratam do tema. Desse modo, apesar de essencialmente relevante para os processos coletivos, porque tem natureza intrínseca a eles, é instituto que não merece, no Brasil, quase nenhum estudo e tem mínima aplicação, geralmente por Tribunais que o afirmam, sem atentarem para seus verdadeiros requisitos e sua real função.

Pretendeu-se, com esse trabalho, revelar a importância do tema, pois, sem sua real observância, não se poderão considerar efetivamente protegidos os direitos transindividuais e, mais do que isso, não se poderá afirmar ser o processo coletivo realmente útil e eficaz em relação a seus objetivos, dentre os quais se incluem a pacificação dos conflitos de maneira generalizada, garantindo, ao mesmo tempo, o acesso à justiça, mas sem atolar a máquina judiciária, por meio da solução molecular de uma série de controvérsias; a garantia de isonomia endo e extraprocessual entre as partes; a redução da litigiosidade futura; a economia processual e a segurança jurídica.

Importante ressaltar que a tutela coletiva dos direitos ultrapassou uma primeira barreira muito importante, que poderia até ter minado seu desenvolvimento, qual seja, a de se considerar tutelável o que, antes, era tido como mero interesse, totalmente desatrelado do conceito de direito subjetivo apto à defesa pelo processo civil clássico, porque não pertencente a um indivíduo determinado. Assim, permitiu-se a tutela do meio ambiente, do patrimônio artístico, dos consumidores coletivamente considerados, de comunidades, de classes e de grupos reunidos em prol de um interesse comum, sem que, necessariamente, se apontasse quem era o titular desse "interesse" que então se levava ao Judiciário. A transposição dessa barreira fulcrada na concepção de direito subjetivo do direito material foi um dos momentos mais importantes para o desenvolvimento dos processos coletivos.

Todavia, mesmo com a sedimentação desse entendimento e com a criação de leis específicas sobre o tema, é certo que o Brasil não atingiu seu ponto máximo de evolução, nem legislativa, nem judiciária, voltada à proteção material dos direitos coletivos e à conferência do status que podem ter os processos coletivos.

Para isso, neste estudo, fez-se necessário, em primeiro lugar, analisar a natureza da ação coletiva, baseando-se nas class actions norte-americanas, que serviram de 
inspiração para a criação dos processos coletivos por todos os países, inclusive de civil law. Nesse ponto, insta salientar que as class actions são ações representativas, o que significa que o autor da demanda não é propriamente o interessado no litígio ou o único envolvido na relação material de fato ou de direito, como ocorre no processo tradicional (artigo $6^{\circ}$ do Código de Processo Civil brasileiro), mas um porta-voz desse grupo de pessoas determináveis ou não, a depender do direito envolvido - que traz a juízo essa pretensão. Esse porta-voz é o representante que fala em nome dos demais, defende os interesses deles em seu próprio nome e por cujos atos serão vinculados todos aqueles que estiverem na mesma categoria, a menos que optem, de início e expressamente, por assim não serem (direito de opt out).

Essa forma não tradicional de representação, porque não derivada da vontade dos interessados ou do texto legal, não é considerada pelo ordenamento norteamericano como ofensiva às garantias constitucionais, como a do devido processo legal, também existente naquele ordenamento. Isso porque se entende que o fair day in Court garantido a todo cidadão não corresponde, necessariamente, à presença física de todos os envolvidos na controvérsia perante os Tribunais, mas ao debate de seu interesse nos Tribunais, o que é suficiente por meio da ação representativa.

É certo que a atuação do representante deve ser fiscalizada durante todo o processo, para garantir a seriedade, a correção, o empenho e a vinculação desse porta-voz que vem a juízo. Caso se verifique que esse representante não é adequado, ainda durante o processo, o juiz tem liberdade de substitui-lo, tudo em nome da escorreita defesa dos direitos coletivos, que se revestem de caráter social. Se, no entanto, um dos envolvidos for atingido por uma decisão contrária a seus interesses pela atuação de um porta-voz que se mostrou inadequado, tem ele o direito de reclamar ao Judiciário, provando a conduta indevida do representante, o que lhe abrirá caminho para uma nova discussão da matéria, em seu próprio nome. Assim, afasta-se, nesse caso, a formação da coisa julgada erga omnes, por meio de instituto jurídico denominado collateral attack.

Desta feita, observa-se que a representatividade adequada é instituto de suma importância nos Estados Unidos, pois define até mesmo quem será atingido pela decisão. Todavia, como se explanou neste estudo, esse instituto não existe a partir da propositura do processo, mas antes dele, pois o representante adequado o é ainda que 
inexistente o processo judicial, podendo, pelas mesmas razões, reclamar administrativamente os direitos do grupo. É, pois, a representatividade adequada uma especial qualidade apresentada pelo representante que atuará em nome da sociedade ou do grupo na defesa de interesses de ordem coletiva, qualidade essa identificada como a possibilidade da defesa eficiente e tenaz dos interesses envolvidos, seja no âmbito social, administrativo ou judicial. E, quando atingida a esfera judicial, esse instituto revela-se uma das condições da ação, pois integra o conceito de legitimidade, haja vista que, se elevado o instituto a princípio dos processos coletivos, como defendemos intrinsecamente já o ser no ordenamento brasileiro, apesar de não expressamente considerado pela lei, não será legítimo o autor, se não for um representante adequado do que pleiteia em juízo.

É certo que o Projeto de Lei n. 5.139/09, ao contrário do que fazia Anteprojeto sobre o tema e do que consta no Código Modelo de Processos Coletivos para Ibero-América, sequer menciona a representatividade adequada dentre seus princípios ou estabelece qualquer necessidade expressa de sua observância, o que é de se lamentar. De qualquer modo, entendemos que o instituto, por ter relação intrínseca com a natureza da demanda, que é representativa, deve ser observado nos processos coletivos brasileiros, já diante da lei posta, no que toca à legitimidade, devendo ser, pois, aferido em relação a todos os legitimados para os processos coletivos, e já se encontra em plena aplicação em relação às ações passivas, espécie de ação não prevista, mas existente de fato.

No Brasil, os legitimados para a propositura da ação coletiva estão especificados na lei, decorrendo a legitimação, pois, ope legis. Desse modo, não existe, a princípio, a necessidade estabelecida pela lei de o juiz verificar a adequação do representante que traz a controvérsia a juízo, sendo, assim, pouco aplicável, ao menos expressamente, o instituto no Brasil. Os Tribunais, muitas vezes, afirmam estar presente a representatividade adequada, mas o que fazem é uma mera análise de interesse do legitimado em face do objeto litigioso, com critério de pertinência temática.

No entanto, como se analisou neste trabalho, é possível já diante da lei posta e mesmo diante da projetada, que não altera essa questão, o controle judicial da representatividade adequada em relação a todos os legitimados. Esse controle é essencial para a efetiva tutela dos direitos coletivos, já que a análise do juiz não se restringirá à verificação do interesse, mas englobará a credibilidade, a seriedade e a postura do 
legitimado diante de outras situações violadoras do mesmo objeto, evitando, inclusive, a promoção pessoal do legitimado ou o conluio entre esse e a parte contrária, em prejuízo dos direitos coletivos.

Atualmente, os processos coletivos brasileiros são promovidos, em sua grande maioria, pelo Ministério Público, entidade pública a que se confere legitimação. Esse fato não é, certamente, o mais adequado para a defesa dos direitos coletivos, pois o ideal seria a organização da sociedade para tanto, mas a legitimidade do ente tem raízes históricas e, no momento, não há como suprimi-la.

Ocorre que, via de regra, os Tribunais não se debruçam sobre a adequação desse órgão para a atuação nessa esfera, limitando-se a afirmar sua legitimidade, porque prevista na lei para a tutela dessa sorte de direitos. Contudo, deve-se ter presente que a função do ente ministerial é pautada pelo artigo 127 da Constituição Federal, que estabelece incumbir a ele a defesa da ordem jurídica, do regime democrático e dos interesses sociais e individuais indisponíveis. Assim, a indisponibilidade ou a relevância social dos direitos pode e deve ser aferida pelo magistrado, a quem se impõe ainda observar se existe a coincidência dos interesses protegidos com aqueles da sociedade. Essa análise não pode ser deixada ao livre arbítrio do Ministério Público, pois se trata de uma das funções primordiais do juiz na ação representativa.

Com relação às associações civis, a postura do Judiciário é um pouco mais favorável à aferição da representatividade adequada, em vista dos requisitos, estabelecidos pelo artigo 82 do Código de Defesa do Consumidor para sua atuação. No entanto, o controle judicial não necessita restar adstrito aos critérios trazidos pela lei, pois ela deixa brecha ao magistrado para realizar uma análise discricionária da idoneidade da associação, ao permitir a dispensa de parte dos requisitos. Assim, a lei traz uma presunção de que as associações que atenderem aos critérios legais sejam adequadas, mas cabe ao magistrado observar, no caso concreto, a representatividade adequada, admitindo ou negando a participação de uma associação, conforme verifique ou não a presença desse requisito.

Importante se fez também a análise da eventual legitimação da pessoa física, que, como se viu, não poderia ter sido afastada pelo Projeto em tramitação, pois, 
desde que exista um efetivo controle dessa pessoa que se coloca como representante, sua atuação judicial só tem a contribuir com o futuro dos processos coletivos. Hoje, o cidadão é legítimo para a propositura de ação popular, voltada à defesa do patrimônio público, mas não o é para a promoção de ações que lhe tocam muito mais diretamente, relacionadas, por exemplo, à sua condição de consumidor, o que não se justifica. Pode ele propor uma ação individual, com projeções coletivas, mas não pode ter sua ação classificada como coletiva, situação que só prejudica o próprio Judiciário, pois permite a multiplicação de ações idênticas por pessoas em igual situação jurídica, como aquelas vistas em relação à atualização de investimentos em função dos planos econômicos. Assim, como proposta de lege ferenda, a legitimação da pessoa física deve ser estabelecida, certamente com uma rigorosa observância de sua representatividade adequada, pois a conferência da legitimidade não prejudica a defesa dos interesses, mas somente a fomenta, fazendo valer também o Estado Democrático de Direito.

A análise do instituto da representatividade adequada não pode ser feita sem deixar de se mencionar a ação coletiva passiva, modalidade de demanda sem previsão expressa no ordenamento brasileiro, mas amplamente aceita pelos Tribunais. Nesse caso, andou mal a lei projetada ao não prever explicitamente seu cabimento, pois a mudança legislativa resolveria uma série de controvérsias existentes quanto a isso. De qualquer forma, a prática atual nos Tribunais, mesmo sem a menção expressa na lei, impõe que se admita sua existência, o que se infere de dispositivos legais esparsos no ordenamento. E, para seu perfeito processamento, essencial é a observância da representatividade adequada, pois ela aqui se reveste de ainda maior importância do que nas ações ativas, haja vista que a pretensão é de um provimento contra o grupo, cujas garantias devem ser, por essa razão, ainda mais fortemente asseguradas. E essa análise é, de certa forma, sem a profundidade necessária, feita pelo Judiciário, como se demonstrou por meio de diversos julgados trazidos a este estudo, pelo que se conclui ser injustificável o Projeto, ao não dispor, expressamente, sobre instituto já existente em nosso ordenamento.

Diante disso, no que toca à legitimidade, é possível concluir que a representatividade adequada é instituto que, no campo processual, integra o seu conceito e que sua aferição não está adstrita à análise legislativa prévia, já que é permitido seu controle judicial, que é realizado além dos requisitos trazidos pela lei para a legitimação das associações, pois também feito em relação ao Ministério Público e aos outros 
legitimados. Isso, além de confirmar a adequação do porta-voz, impedindo a rediscussão da matéria, evita o mau uso da ação coletiva, tão temido nos diversos estudos sobre o tema.

Ademais, a par da influência do instituto na legitimação, verificou-se que ele pode interferir em outras questões inerentes ao processo coletivo, como, por exemplo, na extensão subjetiva dos limites da coisa julgada, que é distinta daquela aplicável aos processos comuns.

A regra geral do processo civil clássico é a de que ninguém que não tenha participado do processo pode ser atingido pela coisa julgada (artigo 472 do Código de Processo Civil), em estrita observância dos princípios do devido processo legal e do contraditório, já que, a princípio, não admite o ordenamento brasileiro que aquele que não foi ouvido possa ter formada contra si uma decisão imutável. No entanto, foram trazidos a este trabalho diversos institutos processuais clássicos por meio dos quais se permite a extensão subjetiva do julgado a terceiro, que não foi parte na demanda, como é o caso das obrigações solidárias, da sucessão processual, da substituição e da assistência.

Algumas das hipóteses contam com a ciência do terceiro quanto ao processo, mas, muitas vezes, consoante se explicitou neste estudo, considera-se que a própria assunção do risco da relação jurídica de direito material implica na subsunção à coisa julgada, como ocorre com a solidariedade. Mas há situações ainda mais graves, como o caso do assistente que, apesar de não ser parte, tem sobre si o ônus da coisa julgada que sobre ele opera não apenas quanto à decisão, como também à sua justiça, ou seja, quanto a seus fundamentos, cuja defesa foram a razão de ser de seu ingresso no processo.

Nos processos coletivos, no entanto, a extensão da coisa julgada erga omnes é a regra geral, indiscriminadamente em relação aos direitos difusos e coletivos, mas só para benefício dos interessados na hipótese de direitos individuais homogêneos (coisa julgada in utilibus). Em qualquer caso, sempre se ressalvam os direitos individuais, em observância ao devido processo legal, ao contraditório e à inafastabilidade da jurisdição, e a coisa julgada não se forma quando a improcedência da ação que verse sobre direitos difusos ou coletivos ocorra por falta de provas, permitindo sua rediscussão por qualquer legitimado. 
Justamente em face da extensão subjetiva da coisa julgada, busca a doutrina ver consolidada na lei a teoria da coisa julgada secundum probationem, por meio da qual a coisa julgada operaria erga omnes, mas restrita às provas produzidas, o que, no entanto, não consta do Projeto de lei em tramitação no Congresso Nacional.

Todas as teorias até agora desenvolvidas foram essenciais para o desenvolvimento dos processos coletivos no Brasil, que teve que se adaptar à estrutura coletiva do processo que, em vários aspectos, se afasta da concepção individual arraigada em nosso ordenamento. Certamente, não se poderia, quando da criação e início de desenvolvimento dos processos coletivos no Brasil, ter sido feita outra opção legislativa. Todavia, entendemos que, no momento atual, em que já se vão vinte e cinco anos da Lei da Ação Civil Pública e vinte anos do Código de Defesa do Consumidor, o ordenamento jurídico brasileiro está pronto para uma alteração legislativa que valorize os processos coletivos.

Para tanto, imprescindível que se analisem as garantias processuais do devido processo legal e do contraditório com outro enfoque, voltado ao seu aspecto social e coletivo, substituindo-se o garantismo individual por um coletivo. Assim, o chamado devido processo legal coletivo propõe a revisitação, sob a ótica de proporcionalidade, dos princípios clássicos, de modo a garantir a efetividade do processo coletivo e a segurança jurídica, talvez a mais importante das garantias para a pacificação social.

E, para tanto, além do aumento da carga de importância da representatividade adequada para a legitimação dos processos coletivos, como aqui já se referiu, essa também deve ser considerada para fins de extensão subjetiva da coisa julgada. Assim, deve ser dada maior relevância ao fato de a ação coletiva ser representativa, conferindo a carga de responsabilidade ao representante adequado que lhe incumbe, o que preferem os Tribunais não fazer, para que não tenham sobre eles a responsabilidade do julgamento de uma demanda que atinja um número tão grande de pessoas. Sem deixar de se apontar a maestria das soluções até hoje existentes para a coisa julgada, entendemos que é no instituto da representatividade adequada que reside a verdadeira garantia do devido processo legal coletivo, pois, com sua estrita observância, poderá se afirmar a coisa julgada erga omnes, sem que se cogite de violações a direitos individuais, pois aquele que estará em juízo defenderá de modo fiel a seu grupo os direitos que a todos tocam. Não se pode 
deixar de fazer referência que o próprio processo civil clássico tem diversas disposições que se afastam de uma feroz defesa das garantias individuais, pelo que essa escusa não pode ser dada para tentar afastar a extensão subjetiva da coisa julgada coletiva.

É certo que essa extensão deve vir acompanhada de mudança legislativa, em que se imponha a estrita observância da representatividade adequada, se assegurem meios para impugnação da decisão, na hipótese de se provas a ausência desse requisito e se garanta o direito de informação, tudo para que se tenha como plenamente aplicado o devido processo legal coletivo, caminhando em conjunto com a necessária segurança jurídica. 


\section{BIBLIOGRAFIA}

ADAMOVICH, Eduardo Henrique Raymundo von, “A Justiça Geométrica e o Anteprojeto de Código de Processos Coletivos: elementos para uma justificativa histórico - filosófica, ou por uma visão atual do alcance e da função criadora da jurisdição coletiva”, in GRINOVER, Ada Pellegrini e outros (coord.). Direito Processual Coletivo e anteprojeto de Código Brasileiro de Processos Coletivos. São Paulo: RT, 2007, p. 55-65.

ALLORIO, Enrico. La cosa giudicata rispetto ai terzi. Milão: Giuffrè, 1992.

ANDRIGHI, Fátima Nancy, "Os limites subjetivos da coisa julgada e o CDC", in SALLES, Carlos Alberto de (coord.). As grandes transformações do processo civil brasileiro: homenagem ao Professor Kazuo Watanabe. São Paulo: Quartier Latin, 2009.

ARAGÃO, Ergas Moniz de. "Observações sobre os limites subjetivos da coisa julgada", in Revista dos Tribunais, ano 76, v. 625, nov./1987, p. 7-26.

ARAÚJO FILHO, Luiz Paulo da Silva. "Tutela jurisdicional dos direitos individuais homogêneos" in Revista Forense, Rio de Janeiro, v. 98, n. 360, mar-abr/2002, p. 363-368.

ARENHART, Sérgio Cruz. Perfis da tutela inibitória coletiva. São Paulo: RT, 2006.

ARMELIN, Donaldo. Legitimidade para agir no direito processual civil brasileiro. São Paulo: RT, 1979.

ARRUDA ALVIM, José Manoel de. "Notas sobre a coisa julgada coletiva", in Revista de Processo, ano 22, v. 88, out-dez/1997, p. 31-57.

. Código do Consumidor comentado. $2^{\mathrm{a}}$ ed., São Paulo: RT, 1995.

ARRUDA ALVIM, Eduardo, "Coisa julgada e litispendência no Anteprojeto de Código Brasileiro de Processos Coletivos", in GRINOVER, Ada Pellegrini e outros (coord.). 
Direito Processual Coletivo e anteprojeto de Código Brasileiro de Processos Coletivos. São Paulo: RT, 2007, p. 174-193.

ASSAGRA DE ALMEIDA, Gregório. Direito processual coletivo brasileiro: um novo ramo do direito processual: princípios, regras interpretativas e a problemática da sua interpretação e aplicação. São Paulo: Saraiva, 2003.

BARBOSA MOREIRA, José Carlos. "A garantia do contraditório na atividade de instrução”. In Temas de Direito Processual, $3^{a}$ série. São Paulo: Saraiva, 1984, p. 61-77.

- “A Legitimação para a Defesa dos 'Interesses Difusos' no Direito Brasileiro". In Temas de Direito Processual, $3^{\text {a }}$ série. São Paulo: Saraiva, 1984, p. 183192.

. "Tutela constitucional dos interesses coletivos ou difusos". In Temas de Direito Processual, $3^{\text {a }}$ série. São Paulo: Saraiva, 1984, p. 193-221.

- "Solidariedade ativa: efeitos da sentença e coisa julgada na ação de cobrança proposta por um único credor", in Revista do Advogado, n. 84, AASP, dez/05.

. “A Ação Popular do Direito Brasileiro como instrumento de tutela jurisdicional dos chamados 'interesses difusos "”. In Temas de Direito Processual, $1^{\mathrm{a}}$ série. São Paulo: Saraiva, 1977, p. 110-123.

- 'Considerações sobre a chamada 'Relativização' da Coisa Julgada Material”, in Revista Dialética de Direito Processual, n. 22, jan/2005, p. 91-111.

BARROS, Humberto Gomes de. Ampliação da legitimidade, superando-se a individualidade restrita: ampliação das hipóteses de ações coletivas. Revista CEJ, Brasília, v. 5, n. 13, jan-abr/2001, p. 56-58.

BARROSO, Luís Roberto. “A proteção coletiva dos direitos no Brasil e alguns aspectos da class action norte-americana", in Revista de Processo, ano 30, n. 130, dez/2005, p. 131153. 
BATISTA, Roberto Carlos. Coisa julgada nas ações civis públicas: direitos humanos e garantismo. Rio de Janeiro: Lumen Juris, 2005.

BEDAQUE, José Roberto dos Santos. "Os elementos objetivos da demanda examinados à luz do contraditório”. In TUCCI, José Rogério Cruz e BEDAQUE, José Roberto dos Santos, coords. Causa de Pedir e pedido no Código de Processo Civil. São Paulo: RT, 2002.

. Direito e processo: influência do direito material sobre o processo. $4^{\mathrm{a}} \mathrm{ed}$., São Paulo: Malheiros, 2006.

BENJAMIN, Antonio Herman V. (coord.). Dano ambiental: prevenção, reparação $e$ repressão. São Paulo: RT, 1993.

BILICH, Edward K. M. e outro, Class actions and other multi-party litigation. St Paul Minn.: West Group, 2000.

BONAVIDES, Paulo, Curso de Direito Constitucional, 12a ed., São Paulo, Malheiros, 2002.

CABIEDES, Pablo Gutiérrez de. "Comentario al art. 3", in Comentários ao Código Modelo de Processos Coletivos. Um diálogo Ibero-Americano. Salvador: Editora Juspodivm, 2009, p. 79-97.

CALAMANDREI, Piero. Eles, os juízes, vistos por um advogado, Eles, os juízes, vistos por um advogado; trad. Eduardo Brandão. 1a ed., 5ª tir., São Paulo: Martins Fontes, 2000.

CANOTILHO, J.J. Gomes. Direito Constitucional e Teoria da Constituição. $5^{\mathrm{a}}$ ed., Coimbra: Almedina, 2002.

CAPITANT, Henri. Vocabulario Jurídico. Buenos Aires: Depalma, 1979. 
CAPPELLETTI, Mauro. The judicial process in comparative perspective. Oxford; New York: Clarendon Press, 1989.

. "Formações sociais e interesses coletivos diante da Justiça Civill, Tradução portuguesa do original italiano por Nelson Renato Palaia Ribeiro de Campos, in Revista de Processo, São Paulo, n. 5, jan-mar/1977, p. 128-159.

CARNELUTTI, Francesco. Trattato del Processo Civile. Napoli: Morano, 1958. . Sistema del diritto processuale civile. Milão: CEDAM, 1936.

CARVALHO, Arthur Oliveira de. "A Coisa Julgada e os Limites da Competência Territorial no Processo Coletivo", in Revista Dialética de Direito Processual, n. 54, set/2007, p. 19-31.

CHIAVARIO, Mario. Processo e garanzie della persona. $2^{\mathrm{a}}$ ed. Milão: Giuffrè, 1982.

CHIOVENDA, Giuseppe. Instituições de Direito Processual Civil, vol. 2, $3^{\text {a }}$ ed. São Paulo: Saraiva, 1969.

COSTA, Susana Henriques da. "O Controle Judicial da representatividade adequada: uma análise dos sistemas norte-americano e brasileiro", in SALLES, Carlos Alberto de (coord.). As grandes transformações do processo civil brasileiro: homenagem ao Professor Kazuo Watanabe. São Paulo: Quartier Latin, 2009.

DE SANTIS, Angelo Danilo. "I disegni di legge italiani sulla tutela degli interessi collettivi e il class action fair act of 2005", in Rivista Trimestrale di Diritto e Procedura Civile, Milão, v. 60, n. 2, jun/2006, p. 601-24.

DIDIER JÚNIOR, Fredie. "O controle jurisdicional da legitimação coletiva e as ações coletivas passivas (o art. 82 do CDC)", in Revista Dialética de Direito Processual, n. 25, abr/2005, p. 50-56. 
. "Comentário ao art. 33" e "Comentário ao art. 37", in Comentários ao Código Modelo de Processos Coletivos. Um diálogo Ibero-Americano. Salvador: Editora Juspodivm, 2009, p. 400/406 e 441/443.

DINAMARCO, Cândido Rangel. Instituições de Direito Processual Civil, II, $2^{\mathrm{a}}$ ed. São Paulo: Malheiros, 2002.

Instituições de Direito Processual Civil, III, $2^{\mathrm{a}}$ ed. São Paulo: Malheiros, 2002.

DINAMARCO, Pedro da Silva. Ação Civil Pública. São Paulo: Saraiva, 2001.

FALCÃO, Joaquim de Arruda, "Justiça Social e Justiça Legal: conflitos de propriedade no Recife", in FALCÃO, Joaquim de Arruda (org.). Conflito de direito de propriedade : invasões urbanas. Rio de Janeiro: Forense, 1984.

FERRARESI, Eurico, “A pessoa física como legitimada à ação coletiva”, in GRINOVER, Ada Pellegrini e outros (coord.). Direito Processual Coletivo e anteprojeto de Código Brasileiro de Processos Coletivos. São Paulo: RT, 2007, p. 136-143.

Ação popular, ação civil pública e mandado de segurança coletivo: instrumentos processuais coletivos. Rio de Janeiro: Forense, 2009.

FISS, Owen. Um novo Processo Civil: estudos norte-americanos sobre jurisdição, constituição e sociedade. São Paulo: RT, 2004.

FORNACIARI JÚNIOR, Clito. "Sucessão processual", in RePro, n. 24, Revista dos Tribunais, out-dez/81.

FREIRE JÚNIOR, Américo Bedê. Os poderes do juiz nas ações coletivas e breves sugestões de lege ferenda ao aprimoramento no processo coletivo. Revista de Processo, São Paulo, v. 29, n. 117, set-out/2004, p. 129-34. 
GABBAY, Daniela, e outro. "Coisa julgada secundum eventum probationis e pedido nas ações coletivas". In SALLES, Carlos Alberto de, SILVA, S. T.., NUSDEO, Ana Maria de Oliveira. Processos coletivos e tutela ambiental. Santos: EDUL - Editora Universitária Leopoldiaum, 2006.

GAMBÔA, João Carlos Corsini. As condições da ação coletiva para a defesa de direitos individuais homogêneos: comparação com as class actions do direito norte-americano, dissertação de Mestrado defendida na Faculdade de Direito da Universidade de São Paulo em 1999, sob orientação do Professor Antônio Carlos de Araújo Cintra.

GIDI, Antonio. A Class Action como instrumento de tutela coletiva dos direitos. As ações coletivas em uma perspectiva comparada. São Paulo: RT, 2007.

. Coisa julgada e litispendência em ações coletivas. São Paulo: Saraiva,

1995.

. Código de Processo Civil coletivo: um modelo para países de direito escrito. Revista de Processo, São Paulo, v. 28, n. 111, jul-set/2003, p. 192-208.

- A representatividade adequada nas ações coletivas brasileiras. Revista de Processo, São Paulo, n. 108, out-dez/2002, p. 61-70.

(coord). Comentários ao Código Modelo de Processos Coletivos. Um diálogo Ibero-Americano. Salvador: Editora Juspodivm, 2009.

GIUSSANI, Andrea. Studi sulle "class actions". Milão: Giuffre, 1996.

GOMES, Flávio Marcelo, "Limites subjetivos da coisa julgada coletiva (ontem, hoje e amanhã)", Revista dos Tribunais, ano 98, v. 889, nov./2009, p. 78/104.

GRINOVER, Ada Pellegrini e outros (coord.). Direito Processual Coletivo e anteprojeto de Código Brasileiro de Processos Coletivos. São Paulo: RT, 2007. 
e outros (coord.). Código Brasileiro de Defesa do Consumidor comentado pelos Autores do Anteprojeto, $6^{\mathrm{a}}$ ed. Rio de Janeiro: Forense, 1999, e $8^{\mathrm{a}}$ ed. Rio de Janeiro: Forense, 2004.

e outros. Os Processos Coletivos nos Países de Civil Law e Common Law: uma análise de direito comparado. São Paulo: RT, 2008.

, "Direito Processual Coletivo", in GRINOVER, Ada Pellegrini e outros (coord.). Direito Processual Coletivo e anteprojeto de Código Brasileiro de Processos Coletivos. São Paulo: RT, 2007, p. 11-15.

, "Da class action for damages à ação de classe brasileira: os requisitos de admissibilidade", in Revista Forense, n. 352. Rio de Janeiro: Forense, 2000.

. Novas tendências do Direito Processual. Rio de Janeiro: Forense, 1990.

. Processo civil coletivo. São Paulo: Quartier Latin, 2005.

. "Ações coletivas ibero-americanas: novas questões sobre a legitimação e a coisa julgada”, in Revista Forense, n. 361. Rio de Janeiro: Forense, 2002.

. A Marcha do Processo. Rio de Janeiro: Forense Universitária, 2000.

. "As garantias constitucionais do processo nas ações coletivas". Revista de Processo, v. 11, n. 43, jul-set/1986, p. 19-30. (coord.). A Tutela dos interesses difusos. São Paulo: Max Limonad, 1984.

GUSMÃO, Paulo Dourado de. Introdução ao Estudo do Direito, 20a ed. Rio de Janeiro: Forense, 1997.

KLONOFF, Robert H. e outro, Class actions and other multi-party litigation, St Paul, Minn., West Group, 2000. 
LARENZ, Karl, Metodologia da ciência do Direito. Tradução de José Lamego, Lisboa, Fundação Calouste Gulbenkian, 1997.

LEAL, Márcio Flávio Mafra, “Anteprojeto de Código Brasileiro de Processos Coletivos Aspectos políticos, econômicos e jurídicos”, in GRINOVER, Ada Pellegrini e outros (coord.). Direito Processual Coletivo e anteprojeto de Código Brasileiro de Processos Coletivos. São Paulo: RT, 2007, p. 66-77.

LENZA, Pedro, Teoria Geral da Ação Civil Pública. São Paulo: RT, 2003.

- Coisa julgada "erga omnes" no direito brasileiro: ações coletivas, controle de constitucionalidade e súmula vinculante), tese de Doutorado defendida na Faculdade de Direito da Universidade de São Paulo em 2006, sob orientação da Professora Ada Pellegrini Grinover.

LEONEL, Ricardo de Barros. Manual do processo coletivo. São Paulo: RT, 2002.

LIEBMAN, Enrico. Manuale di Diritto Processuale Civile, III, $3^{\mathrm{a}}$ ed. Milão: Giuffrè, 1976.

LUCON, Paulo Henrique dos Santos e outro. "Coisa julgada secundum eventum probationis e pedido nas ações coletivas". In SALLES, Carlos Alberto de, SILVA, S. T.., NUSDEO, Ana Maria de Oliveira. Processos coletivos e tutela ambiental. Santos: EDUL Editora Universitária Leopoldiaum, 2006.

MAC-GREGOR, Eduardo Ferrer (coord). Comentários ao Código Modelo de Processos Coletivos. Um diálogo Ibero-Americano. Salvador: Editora Juspodivm, 2009.

MAIA, Diogo Campos Medina. Ação Coletiva Passiva. Rio de Janeiro: Lumen Juris, 2009.

MARINONI, Luiz Guilherme e outro. Código de Processo Civil comentado artigo por artigo, $3^{\mathrm{a}}$ tir. São Paulo: RT, 2008. 
MANCUSO, Rodolfo de Camargo. Ação Civil Pública em defesa do Meio Ambiente, do Patrimônio Cultural e dos Consumidores, $7^{\mathrm{a}}$ ed. São Paulo: RT, 2001.

Interesses Difusos - Conceito e legitimação para agir. $6^{\mathrm{a}}$ ed., revista, atualizada e ampliada. São Paulo: RT, 2004.

A proteção judicial de interesses difusos e coletivos: funções $e$ significados. São Paulo: RT, 2003.

. Jurisdição coletiva e coisa julgada: teoria geral das ações coletivas. $2^{\mathrm{a}}$ ed. São Paulo: RT, 2007.

. "Coisa julgada, collateral esttoppel e eficácia preclusiva secundum eventum litis", in Revista dos Tribunais, v. 75, n. 608, dez/2000, p. 20-47.

. "Interesse difuso a programação televisiva de boa qualidade, e sua tutela jurisdicional", in Revista dos Tribunais, v. 83, n. 705, jul/1994, p. 51-62.

MATTOS, Luiz Norton Baptista de. "A litispendência e a coisa julgada nas ações coletivas segundo o Código de Defesa do Consumidor e os Anteprojetos do Código Brasileiro de Processos Coletivos", in GRINOVER, Ada Pellegrini e outros (coord.). Direito Processual Coletivo e anteprojeto de Código Brasileiro de Processos Coletivos. São Paulo: RT, 2007, p. $194 / 215$.

MAZZEI, Rodrigo, (coord.) e outros. Processo civil coletivo. São Paulo: Quartier Latin, 2005.

MAZZILLI, Hugo Nigro. Tutela dos interesses difusos e coletivos. $6^{\text {a }}$ ed., São Paulo: Damásio de Jesus, 2007.

MEDINA, Paulo Roberto de Gouvêa. "Coisa julgada: garantia constitucional”, in Revista de Processo, ano 32, v. 146, abr/2007, p. 11-31. 
MENDES, Aluisio Gonçalves de Castro. Ações coletivas no direito comparado e nacional, $2^{\text {a }}$ ed. São Paulo: RT, 2010.

, "O Anteprojeto de Código Brasileiro de Processos Coletivos: visão geral e aspectos sensíveis", in GRINOVER, Ada Pellegrini e outros (coord.). Direito Processual Coletivo e anteprojeto de Código Brasileiro de Processos Coletivos, São Paulo, RT, 2007, p. 16-32.

MESQUITA, José Ignácio Botelho de. “A Coisa Julgada no Código do Consumidor”, in TUCCI, José Rogério Cruz e (coord.). Processo Civil: estudo em comemoração aos 20 anos de vigência, São Paulo: Saraiva, 1995.

, "Na ação do consumidor, pode ser inútil a defesa do fornecedor", in Revista do Advogado, n. 33, AASP, 1990, p. 80-82.

MIRRA, Álvaro Luiz Valery, “Associações civis e a defesa dos interesses difusos em juízo: do direito vigente ao direito projetado", in GRINOVER, Ada Pellegrini e outros (coord.). Direito Processual Coletivo e anteprojeto de Código Brasileiro de Processos Coletivos. São Paulo: RT, 2007, p. 114-135.

, "A legitimidade ativa do Ministério Público para a defesa dos direitos individuais homogêneos", in SALLES, Carlos Alberto de, SILVA, S. T.., NUSDEO, Ana Maria de Oliveira. Processos coletivos e tutela ambiental. Santos: EDUL - Editora Universitária Leopoldiaum, 2006.

, “Ação Civil Pública em Defesa do Meio Ambiente: a representatividade adequada dos entes intermediários legitimados para a causa”, in MILARÉ, Edis (coord.). A Ação Civil Pública após 20 anos: efetividade e desafios. São Paulo: Revista dos Tribunais, 2005.

MONTELEONE, Girolamo A. Limiti soggettivi del giudicato civile. Padova: Cedam, 1978. 
MORI, Celso Cintra. "A litispendência entre ações individuais e ações civis coletivas em defesa dos interesses individuais homogêneos", in Revista do Advogado, n. 84, AASP, dez/05, p. 27-40.

MULLENIX, Linda e outros. Os Processos Coletivos nos Países de Civil Law e Common Law: uma análise de direito comparado. São Paulo: RT, 2008.

NERY JÚNIOR, Nelson. “O Ministério Público e as Ações Coletivas”, in MILARÉ, Edis (coord.). Ação Civil Pública (Lei 7.347/85 - Reminiscências e Reflexões após dez anos de aplicação). São Paulo: Revista dos Tribunais, 1995.

NUNES, Rizzato. Comentários ao Código de Defesa do Consumidor, 4 a ed. São Paulo: Saraiva, 2009.

NOLASCO, Rita Dias (coord.) e outros. Processo civil coletivo. São Paulo: Quartier Latin, 2005.

OLIVEIRA, Swarai Cervone de. Poderes do juiz nas ações coletivas, dissertação de Mestrado defendida na Faculdade de Direito da Universidade de São Paulo em 2007, sob orientação do Professor José Rogério Cruz e Tucci.

PASCHOAL, Maximiliam Fierro. A representatividade adequada na Ação Coletiva Brasileira (Lei da Ação Civil Pública e Código de Defesa do Consumidor), dissertação de Mestrado defendida na Faculdade de Direito da Universidade de São Paulo em 2007, sob orientação do Professor Kazuo Watanabe.

PROENÇA, Luis Roberto. Inquérito Civil - Atuação investigativa do Ministério Público a serviço da ampliação do acesso à Justiça. São Paulo: Revista dos Tribunais, 2001.

RAMOS, Elival da Silva. A proteção aos direitos adquiridos no Direito Constitucional brasileiro. São Paulo: Saraiva, 2003.

RIZZI, Sérgio. Ação Rescisória. São Paulo: Revista dos Tribunais, 1979. 
ROCHA, Fernando Antonio Dusi. Ampliação da legitimidade, superando-se a individualidade restrita: ampliação das hipóteses de ações coletivas. Revista CEJ, Brasília, v. 5, n. 13, jan-abr/2001, p. 51-55.

RODRIGUES NETO, Nelson. "O uso de ações coletivas passivas e bilaterais para proteção de direitos na internet". In Revista do Curso de Direito do Centro Universitário das Faculdades Metropolitanas Unidas, v.20, n.28, 2006, p. 95-105.

SALLES, Carlos Alberto de (coord.). Processo civil e interesse público. São Paulo: RT, 2003.

SALLES, Carlos Alberto de. "Ações coletivas: premissas para comparação com o sistema jurídico norte-americano", in SALLES, Carlos Alberto de, SILVA, S. T.., NUSDEO, Ana Maria de Oliveira. Processos coletivos e tutela ambiental. Santos: EDUL - Editora Universitária Leopoldiaum, 2006.

SAVIGNY, Friedrich Karl Von. Sistema Del diritto romano attuale. Tradução italiana do original alemão por Vittorio Scialoja. Torino: Udinese Tipográfico - Editrice Torinese, 1900.

SCARPINELla BUENO, Cassio. Partes e Terceiros no Processo Civil Brasileiro. São Paulo: Saraiva, 2003.

. "As class actions norte-americanas e as ações coletivas brasileiras: pontos para uma reflexão conjunta", in Revista de Processo, ano 21, n. 82, abr.-jun./1996, p. 92151.

SOSA, Angel Ladoni. "La cosa juzgada en los procesos colectivos" in YARSHELL, Flávio Luiz, e ZANÓIDE DE MORAES, Maurício (coords.). Estudos em Homenagem à Professora Ada Pellegrini Grinover, São Paulo: DPJ, 2005.

SOUZA, Artur César de. Contraditório e Revelia. São Paulo: RT, 2003. 
STUMM, Raquel Denize, Princípio da proporcionalidade no Direito Constitucional Brasileiro, São Paulo, Livraria dos Advogados, 1995.

TALAMINI, Eduardo. Coisa Julgada e sua Revisão, São Paulo: RT, 2005.

TUCCI, José Rogério Cruz e. Limites Subjetivos da Eficácia da Sentença e da Coisa Julgada Civil, Tese apresentada para concurso ao cargo de Professor Titular de Direito Processual Civil da Faculdade de Direito da Universidade de São Paulo, São Paulo, 2006.

. "Garantias Constitucionais do processo em relação aos terceiros". in Revista do Advogado, n. 99, AASP, set/08, p. 62-79.

. “Class action” e mandado de segurança coletivo: diversificações conceptuais. São Paulo: Saraiva, 1990.

. (coord.). Processo Civil: estudo em comemoração aos 20 anos de vigência. São Paulo: Saraiva, 1995

VENTURI, Elton. “Apontamentos sobre o processo coletivo, o acesso à justiça e o devido processo social" in Revista da Procuradoria Geral do Estado do Paraná, Curitiba, v. 9, n. 4, jul/95, p. 24-56.

. "Comentário ao art. $3^{\circ}$ ", in Comentários ao Código Modelo de Processos Coletivos. Um diálogo Ibero-Americano. Salvador: Editora Juspodivm, 2009, p. 70-79.

VIGLIAR, José Marcelo de Menezes. Tutela jurisdicional coletiva. São Paulo: Atlas, 1979.

, "Defendant class action brasileira: limites propostos para o 'Código de Processos Coletivos"”, in GRINOVER, Ada Pellegrini e outros (coord.). Direito Processual Coletivo e anteprojeto de Código Brasileiro de Processos Coletivos. São Paulo: RT, 2007, p. 309-320. 
VIGORITTI, Vincenzo. Interesse collettivi e processo - la legitimazione ad agire. Milão: Giuffrè, 1979.

VIOLIN, Jordão. Ação Coletiva Passiva: fundamentos e perfis. Salvador: Editora Juspodivm, 2008.

WATANABE, Kazuo e outros (coord.). Direito Processual Coletivo e anteprojeto de Código Brasileiro de Processos Coletivos. São Paulo: RT, 2007.

e outros. Os Processos Coletivos nos Países de Civil Law e Common Law: uma análise de direito comparado. São Paulo: RT, 2008. , "Disposições gerais", in Código Brasileiro de Defesa do Consumidor comentado pelos Autores do Anteprojeto, GRINOVER, Ada Pellegrini e outros (coord.), $6^{\mathrm{a}}$ ed. Rio de Janeiro: Forense, 1999, e $8^{\text {a }}$ ed. Rio de Janeiro: Forense, 2004.

ZACLIS, Lionel. Proteção coletiva dos investidores no mercado de capitais. São Paulo: RT, 2007.

ZAVASCKI, Teori Albino. Processo Coletivo - Tutela de Direitos Coletivos e Tutela Coletiva de Direitos, $3^{\text {a }}$ ed. Revista, atualizada e ampliada. São Paulo: RT, 2008.

ZUFELATO, Camilo. Coisa julgada coletiva, tese de Doutorado defendida na Faculdade de Direito da Universidade de São Paulo em 2008, sob orientação da Professora Ada Pellegrini Grinover. 


\section{RESUMO}

O objetivo central do presente trabalho é a análise do instituto da representatividade adequada nos processos coletivos, de modo a se contribuir para majorar a eficácia de proteção dos direitos coletivos amplamente considerados, especialmente porque esse instituto de suma relevância não é princípio dos processos coletivos no Brasil.

Os direitos coletivos tiveram seu estudo iniciado a partir do momento em que as pessoas tomaram consciência de sua condição de indivíduos inseridos na comunidade em que vivem, buscando na sociedade massificada e junto aos outros em mesma situação amparo para seus problemas e força para suas reivindicações. Assim, absorvida essa consciência de classe pelos indivíduos, o que começou a ocorrer em meados do século XVIII, nos países de ordenamento de common law, teve início o desenvolvimento dos processos coletivos, que chegaram a um considerável nível de maturação somente no século XX.

Pretendeu-se, com esse trabalho, revelar a importância do instituto da representatividade adequada, pois, sem sua real observância, não se poderão considerar efetivamente protegidos os direitos transindividuais e, mais do que isso, não se poderá afirmar ser o processo coletivo realmente útil e eficaz em relação a seus objetivos.

Assim, demonstrou-se que a representatividade adequada é instituto essencial para a legitimação para as ações coletivas, já com base na lei posta, devendo ser aferida pelo magistrado não só em relação às associações, mas também ao Ministério Público e à pessoa física, a quem entendemos deva ser estendida a legitimidade. Ademais, em relação às ações coletivas passivas, não previstas em nosso ordenamento, mas existentes de fato, a observância do instituto é essencial para que não se violem garantias elementares do indivíduo.

Outrossim, a representatividade adequada tem aplicação em relação à coisa julgada, pois, por meio de sua observância, se poderá impor a coisa julgada erga omnes, sem que se aleguem violações a direitos e garantias individuais, pois assegurado estará o devido processo legal coletivo. 


\begin{abstract}
The main goal of this study is the adequacy of representation analysis, to contribute to enlarge the protection of the collective rights, especially because this very important institute is not a principle of the collective suits in Brazil.
\end{abstract}

Transindividual rights have begun to been studied from the time people became aware of their status as individuals living in community, seeking in the mass society and with others in the same situation help for their problems and strength to their claims. Absorbed this class-consciousness by the individuals, which begins in the middle 1900s in the countries with common law rights, began the development of collective process, which reaches an important level of maturation at the XX century.

The intention of this work was to reveal the significance of the adequacy of representation, because without their actual compliance, there can not be considered effectively protected the collective rights and it will not be possible to affirm that the collective process are really useful and effective in relation to their goals.

Thus, it was shown that the adequacy of representation is essential institute for the standing for the class actions, already by the actual legislation. It must be observed by the judge not only in relation to the civil associations, but also to the Public Prosecution Service and to the citizen itself, that we considered should be possible to propose collective actions. Otherwise, in relation to the defendant class actions, not foreseen in our laws, but actually existing, the compliance with the institute is essential, so as not to infringe basic individual guarantees.

Furthermore, the adequacy of representation has to be applied in relation to res judicata, because, with its compliance, it would be possible to impose the erga omnes res judicata, without be possible to argue violations to individual rights and guarantees, because it would be ensured the social due process. 


\section{RIASSUNTO}

Lo scopo centrale di questo studio è l'analisi dell' istituto della rappresentatività adeguata nei processi collettivi, per contribuire all' aumento dell' efficacia della protezione dei diritti collettivi, in particolare perché questo importante istituto non è un principio dei processi collettivi in Brasile.

I diritti collettivi hanno cominciato a essere studiati dal momento in cui le persone hanno preso coscienza di vivere in comunità, cercando nella società di massa e assieme agli altri nella stessa situazione forza per le loro domande e protezione per i loro problemi. Così, assorbita questa coscienza di classe dalle persone, ciò che ha iniziato dal secolo XVIII, nei paesi di common law, ha cominciato lo sviluppo dei processi collettivi, che hanno raggiunto un notevole livello di maturità soltanto nel secolo XX.

Abbiamo voluto, con questo lavoro, dimostrare l'importanza della rappresentatività adeguata, perché, senza la sua osservanza effettiva, non si potrá considerare che i diritti collettivi siano protetti e, ancor piú, non si potrá affermare che i processi collettivi siano utili e efficaci per i loro scopi.

Abbiamo dimostrato che la rappresentatività adeguata è istituto essenziale per la legittimazione delle azioni collettive, già di lege lata e dovrebbe essere osservata dal giudice non soltanto riguardo alle associazioni, ma anche al Pubblico Ministero e alla persona individuale, ai quali difendiamo che debba essere estesa la legittimazione. Inoltre, nel caso delle domande collettive passive, non previste dalla legge, ma di fatto esistenti, il rispetto all'istituto è essenziale perché non siano violate garanzie elementare delle persone.

Allo stesso modo, la rappresentatività adeguata può essere applicata riguardo alla res judicata, perché, se rispettata, sarà possibile avere la res judicata erga omnes, senza che si possa affermare violazione a diritti e garanzie individuali, perché assicurato sarà il giusto processo collettivo. 